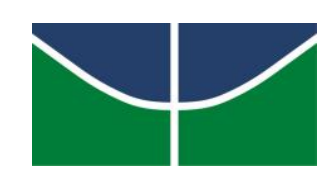

Universidade de Brasilia (UnB)

Faculdade de Ciência da Informação (FCl)

Programa de Pós-Graduação em Ciência da Informação (PPGCInf)

\title{
Tratamento Informacional da Coleção Telegráfica do Museu Correios: Análise sob a Perspectiva Científica, Tecnológica e de Cultura Material
}

\author{
Orientadora: \\ Prof ${ }^{a}$ Dr ${ }^{\mathrm{a}}$ Lillian Maria Araújo de Rezende Alvares
}

Bernardo de Barros Arribada

Brasília

2016 
Bernardo de Barros Arribada

\section{Tratamento Informacional da Coleção Telegráfica do Museu Correios: Análise sob a Perspectiva Científica, Tecnológica e de Cultura Material}

Dissertação apresentada ao Programa de PósGraduação em Ciência da Informação da Universidade de Brasília, como requisito parcial à obtenção do título de Mestre em Ciência da Informação.

\section{Orientadora:}

Prof ${ }^{a}$ Dra Lillian Maria Araújo de Rezende Alvares 
A775

ARRIBADA, Bernardo de Barros.

Tratamento Informacional da Coleção Telegráfica do Museu Correios: análise sob a perspectiva científica, tecnológica e de cultura material / Bernardo de Barros Arribada. Brasília: Universidade de Brasília. 2016.

$164 \mathrm{fls}$.

Orientadora: Lillian Maria Araújo de Rezende Alvares.

Dissertação (Mestrado) - Universidade de Brasília, Brasília, 2016.

1. Informação e Documentação em Museus. 2. Museus de Ciência e Tecnologia 3. Patrimônio de Ciência e Tecnologia. 4. Estudos de Cultura Material I. Bernardo de Barros Arribada. II. Título. 


\section{FOLHA DE APROVAÇÃO}

Título: "Tratamento Informacional da Coleção Telegráfica do Museu Correios: análise da perspectiva científica, tecnológica e de cultura material.".

\section{Autor (a): BERNARDO DE BARROS ARRIBADA}

Área de concentração: Gestão da Informação

Linha de pesquisa: Organização da Informação

Dissertação submetida à Comissão Examinadora designada pelo Colegiado do Programa de Pósgraduação em Ciência da Informação da Faculdade em Ciência da Informação da Universidade de Brasília como requisito parcial para obtenção do título de Mestre em Ciência da Informação.

Brasília, 16 de fevereiro de 2016.

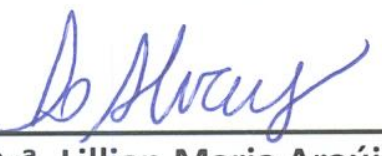

Profa. Drá. Lillian Maria Araújo de Rezende Alvares

Presidente (UnB/PPGCINF)

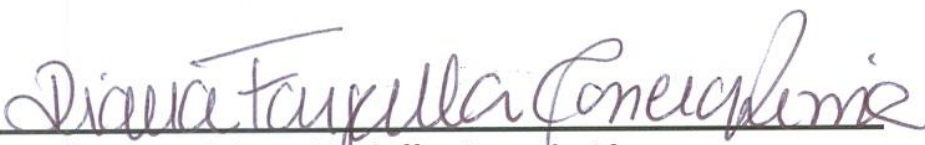

Profa. Dra. Diana Färjalla Correia Lima

Membro Titular (UNIRIO)

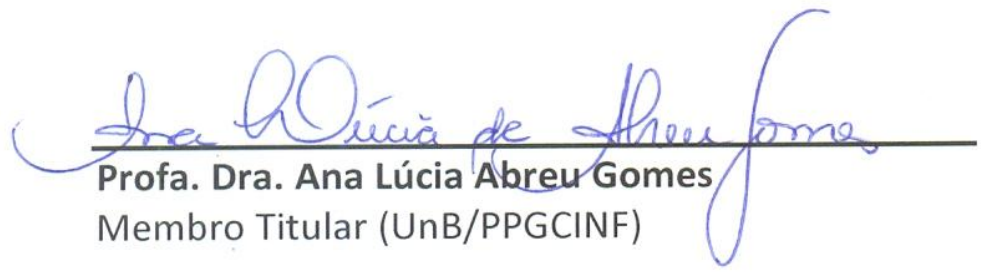

Profa. Dra. Miriam Paula Manini

Membro Suplente (UnB/PPGCINF) 
Para minha avó (in memoriam)

Que sempre esteve presente, fazendo tudo o que estava ao seu alcance para que eu chegasse aonde estou....

E para minha mãe Que sempre me deu todo o apoio para ser o que sou e nunca deixou que eu parasse no tempo ou deixasse de correr atrás dos meus sonhos. 


\section{Agradecimentos}

Aos Correios, por ter apoiado com a aprovação no Edital de Bolsas de Estudo 2014, possibilitando que eu desse mais um passo na minha carreira.

A Romulo Salvino, chefe do Departamento de Gestão Cultural, e Andre Ronzani, gerente corporativo do Museu Correios, por me apoiarem e darem condições para a realização do mestrado.

Aos professores do PPGCinf por toda a paciência e por todos os ensinamento que me foram passados nas disciplinas cursadas.

À Prof. Dra. Miriam Manini, por ter avaliado meu pré-projeto, fazendo colocações extremamente pertinentes e que me fizeram repensar seu conteúdo e proposta, e por aceitar, com muita prontidão, preocupação e carinho, participar de minha Banca Examinadora.

À Prof. Dra. Ana Abreu pelas conversas e bate-papos, trocas e reflexões, por me ajudar a quebrar a cabeça em tantos problemas "cabeludos" que eu levava durante a disciplina Estudos em Memória e Patrimônio Cultural, e, por mais uma vez, e com muita alegria, aceitar me avaliar.

À Prof. Dra. Lillian Alvares por responder o email de um aluno doido em 2013, por aceitar orientá-lo e cair de cabeça nesse mundo mágico da Informação em Museologia, e por me receber sempre com um sorriso imenso e com paciência e carinho para as manhãs de orientação.

À Prof. Dra. Diana Farjalla, minha mestra, guru, professora, orientadora, e "mãe museológica", por me acompanhar desde meu terceiro período da graduação. E, principalmente, por plantar em mim a sementinha do pesquisador e me iluminar, me apresentando à Ciência da Informação. Muito obrigado por, mais uma vez, estar presente em minhas realizações. Que venham outras!

À Liliane Juvência e Daniele Pestana, que desde o primeiro momento estiveram comigo e, independente de distância, horário e motivo, sempre se prontificaram a estar ao meu lado. Obrigado pelas trocas, pela amizade, pelo carinho, pelas gargalhadas.

À Rose Miranda, Alexandra Zinn e a todos os amigos do PPGCInf e da vida, pelos encontros, risadas, desesperos, angústias, noites em botecos, reflexões, textos, informações, enfim, por vivermos, sofrermos a amarmos cada dia desses dois anos de convivência. AVANTE... e que seja pra sempre!!

Aos amigos do Museu Correios, em especial à Tatianne Neves, por me acompanhar mais de perto, e por vivenciar comigo um pouco desses dois anos de mestrado, e à Renata Assiz, por me auxiliar com informações para análise da coleção e do ciclo documental do Museu Correios.

À minha família e a Juarez Galdino, por nunca me deixar desistir, por me segurarem quando eu precisei, por não me deixar jogar tudo pra cima, por me acalmar nos momentos de estresse, e por simplesmente existirem em minha vida. 


\section{Museum needs objects and objects need documentation}

Monika Hagedorn-Saupe, 2008 


\section{Resumo}

O Museu Correios (MC), instituição ligada à Empresa Brasileira de Correios e Telégrafos (ECT), detém em seu acervo grande parte da História das Comunicações no Brasil, materializada em sua coleção telegráfica. Esses objetos, ao serem processados pela chamada Documentação em Museus, tornam-se objetosdocumento dessa história. No entanto, as informações museológicas dos objetos e seus contextos históricos e tecnológicos não estão processadas de acordo com as normas técnicas de documentação propostas por órgãos nacionais e internacionais que se debruçam sobre o tema. Essa situação não é favorável para o Museu Correios enquanto instituição de pesquisa, produtora de informação e, consequentemente, de conhecimento. Neste cenário, a presente pesquisa, baseando-se nas teorias da Cultura Material que visam análise e descrição de objetos, buscou identificar metodologia apropriada para a Documentação no Museu Correios. Conclui que esses métodos podem ser aplicados ao ambiente museológico no momento da Análise da Informação em Museologia, processo que faz parte da Documentação em Museus.

Palavras-chave: Patrimônio Científico e Tecnológico. Documentação e Informação em Museus. Análise da Informação. Museu Correios. Coleção Telegráfica. 


\begin{abstract}
The Postal Museum (MC), an institution linked to the Brazilian Post and Telegraph Corporation (ECT), holds in its large collection part of the History of Communications in Brazil, exhibited in its telegraphic collection. These objects, will be processed by what is called Museums Documentation, and will become objects-documents of this history. However, the museological information of the objects and their technological and historical contexts are not to be processed in accordance with the technical standards of documentation proposals by national and international bodies dealing with the subject. This situation is not favorable for the Postal Museum as a research institution, a producer of information and, as a consequence, knowledge. In this scenario, this research, based on the theories of Material Culture aimed at the analysis and description of objects, sought to identify an appropriate methodology for the documentation in the Postal Museum. We conclude that these methods can now be applied in a museum environment with the Analysis of Information in Museology that is part of the Museums Documentation.
\end{abstract}

Keywords: Cientific and Technological Heritage. Museum Documentation and Information. Information Analysis. Postal Museum. Telegraphic Collection. 


\section{Lista de Figuras}

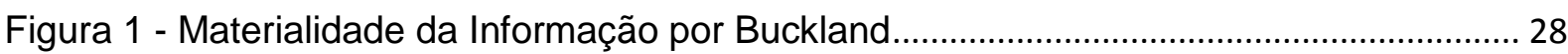

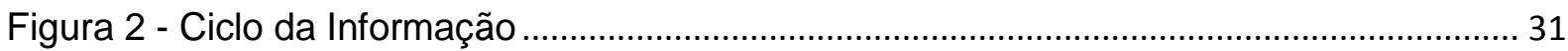

Figura 3 - Análise da Informação e seu Papel no Ciclo Documentário ..................................... 45

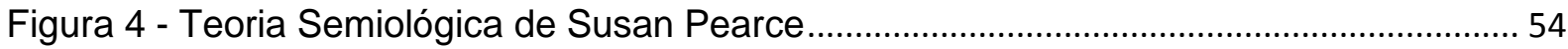

Figura 5 - Sala de Experiências do Museu Telegráfico.................................................................. 59

Figura 6 - Museu - Sala dos Materiais e Ferramentas das Linhas ............................................. 59

Figura 7 - Interior de Agência no início do século XX e reprodução no Museu Correios ........ 61

Figura 8 - Estação de Telegrafia Ótica do Morro do Castelo - Rio de Janeiro ........................... 63

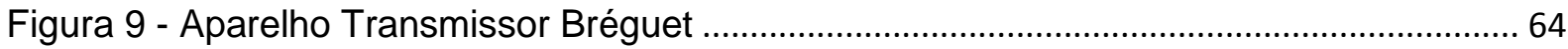

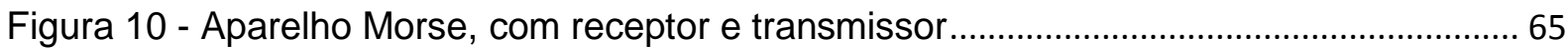

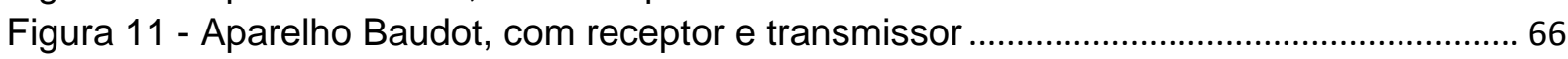

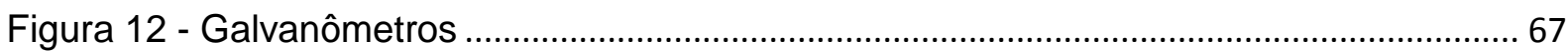

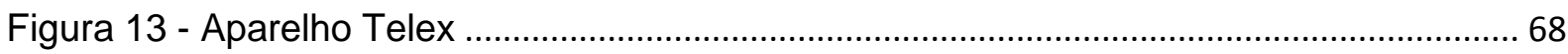

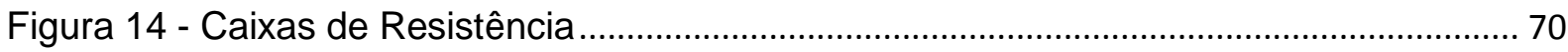

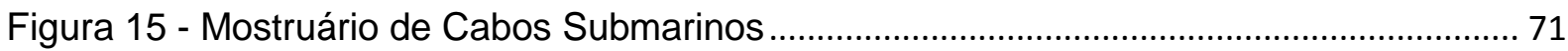

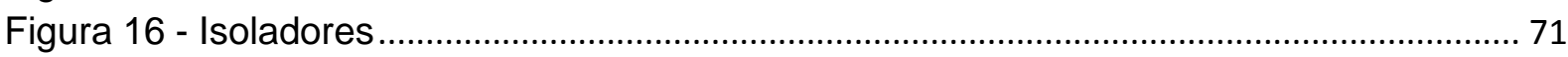

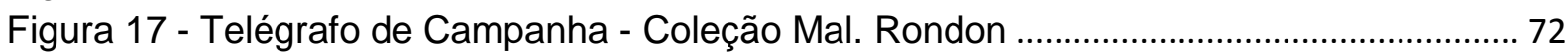

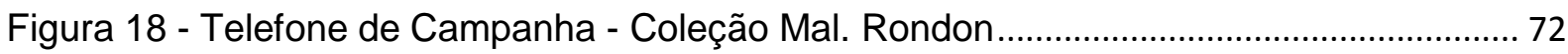

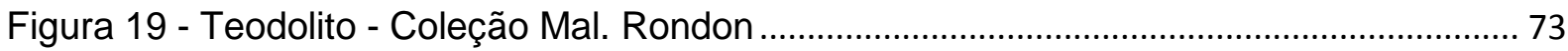

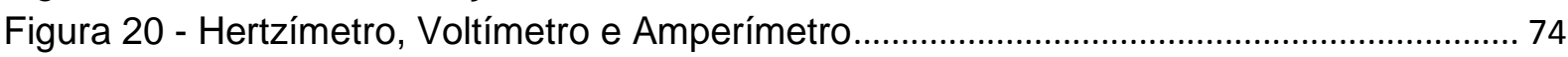

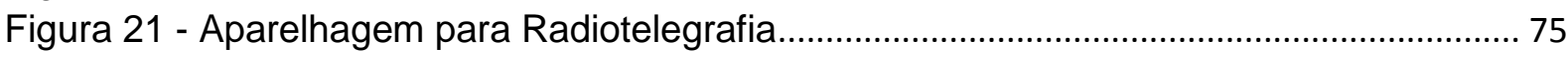

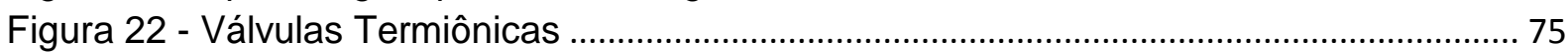

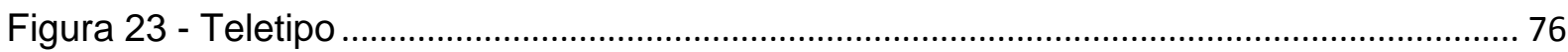

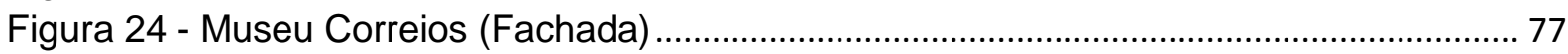

Figura 25 - Exposição de Longa Duração - Museu Correios ..................................................... 78

Figura 26 - Exposição Temporária - Museu Correios................................................................... 78

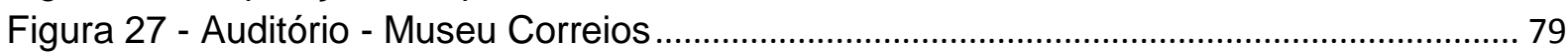

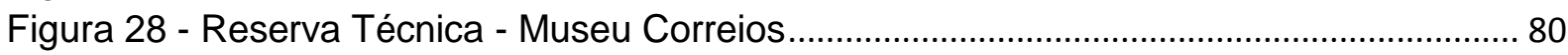

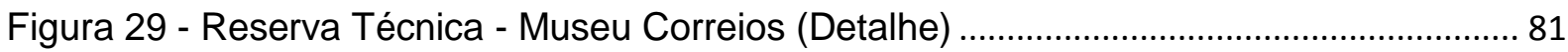

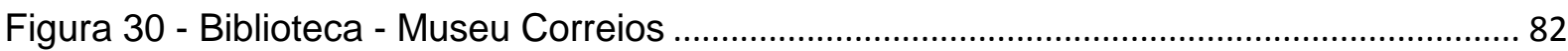

Figura 31 - Arquivo - Museu Correios .................................................................................. 82

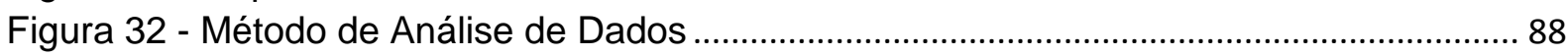

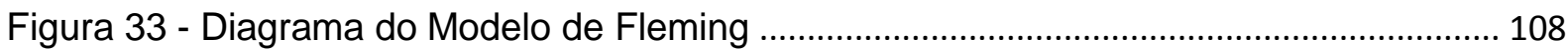

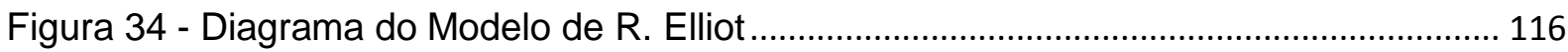

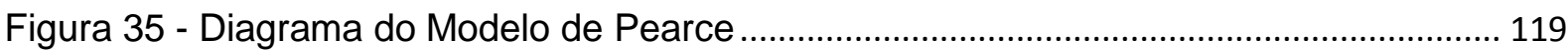

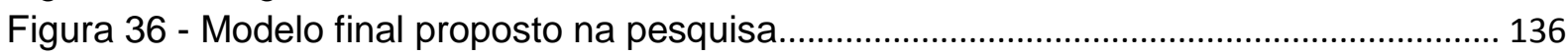

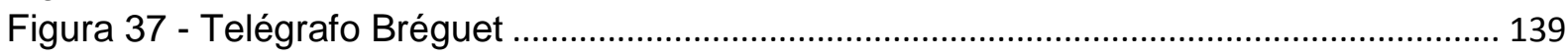

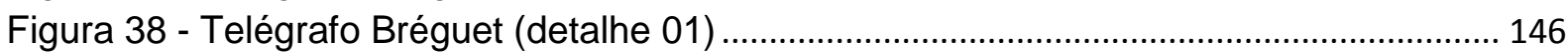

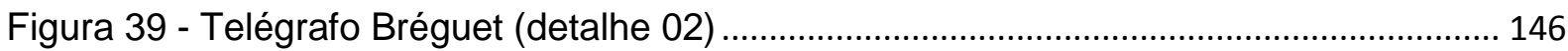

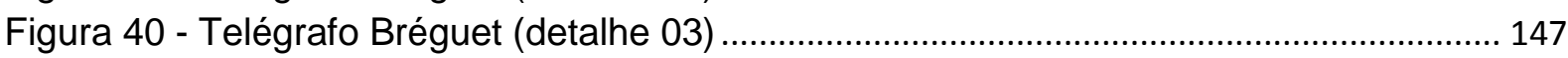

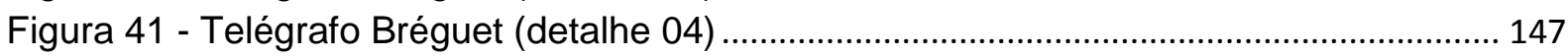

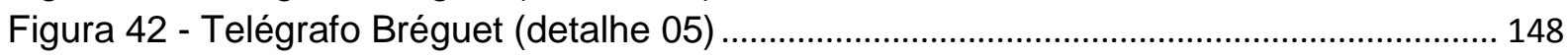




\section{Lista de Quadros}

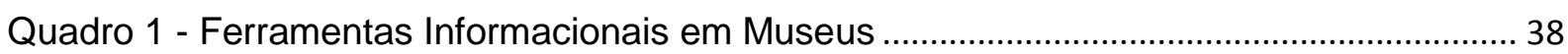

Quadro 2 - Processos Documentais na definição de Documentação da MGC......................... 39

Quadro 3 - Modelo Informacional de Peter van Mensch ............................................................ 40

Quadro 4 - Categorias de Informação do Object ID ..................................................................... 42

Quadro 5 - Categorias de Inforção do IGMO (CIDOC) …............................................................. 43

Quadro 6 - Modelos de Estudo de Objetos propostos por Susan Pearce para aplicação em

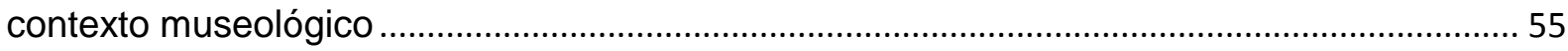

Quadro 7 - Parâmetros para Análise dos Estudos de Cultura Material ...................................... 86

Quadro 8 - Parâmetros para a análise do sistema de documentação do Museu Correios -

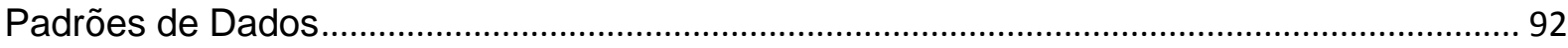

Quadro 9 - Estrutura dos Dados - Parâmetros de Análise ......................................................... 93

Quadro 10 - Campos de Informação - Comparação entre Padrões de Documentação .......... 95

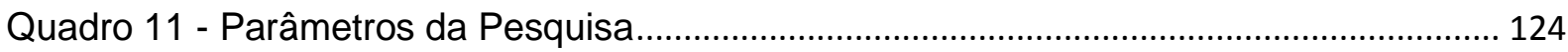

Quadro 12 - Dados Coletados - Origem Disciplinar.................................................................... 125

Quadro 13 - Dados Coletados - Contexto de Criação do Modelo ............................................ 126

Quadro 14 - Dados Coletados - Aplicação em Contexto Museológico .................................... 127

Quadro 15 - Dados Coletados - Metodologia proposta nos Estudos de Cultura Material .... 128

Quadro 16 - Dados Coletados - Camada de Informação......................................................... 132

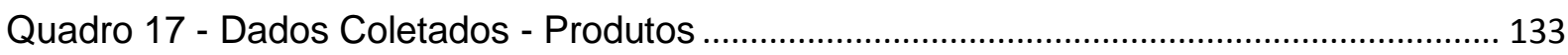

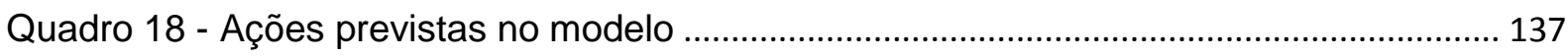

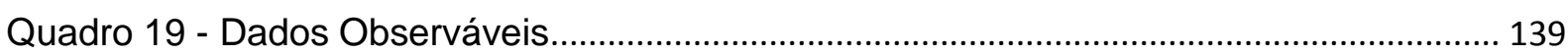

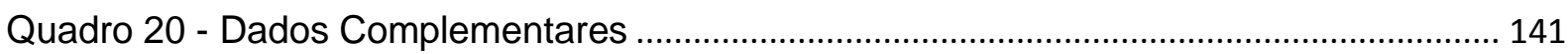

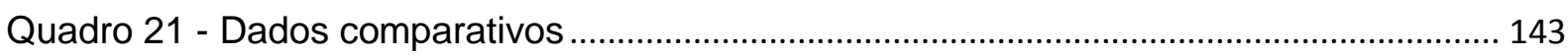




\section{Lista de Abreviaturas e Siglas}

AAT - The Art \& Architetures Thesaurus

AFRICOM - Conselho Internacional dos Museus Africanos

CEDOC - Centro de Documentação

C\&T - Ciência e Tecnologia

Cl - Ciência da Informação

CIDOC - Comitê para Documentação

CONA - The Cultural Objects Name Authority

DC - Diretoria de Correios

DCT - Departamento de Correios e Telégrafos

DEGEC - Departamento de Gestão Cultural

DR - Diretoria Regional

ECT - Empresa Brasileira de Correios e Telégrafos

IBRAM - Instituto Brasileiro de Museus

ICOFOM - Comitê Internacional para a Museologia

ICOM - Conselho Internacional de Museus

IIB - Instituto Internacional de Bibliografia

INBCM - Inventário Nacional de Bens Culturais Musealizados

IPHAN - Instituto do Patrimônio Histórico e Artístico Nacional

MA - Museum Association

MAST - Museu de Astronomia e Ciências Afins

MC - Museu Correios

MCTI - Ministério de Ciência, Tecnologia e Inovação

MDA - Museum Documentation Association

MGC - Museums \& Galleries Commision

MHN - Museu Histórico Nacional

MinC - Ministério da Cultura

OC - Organização do Conhecimento

OI - Organização da Informação

OIC - Organização da Informação e do Conhecimento

PPGCInf - Programa de Pós-Graduação em Ciência da Informação

RBU - Repertório Bibliográfico Universal

RGT - Repartição de Correios e Telégrafos

SOC - Sistemas de Organização do Conhecimento

TGN - The Getty Thesaurus of Geographic Names

UFOD - União Francesa de Organismos de Documentação

ULAN - The Union List of Artists Names

UnB - Universidade de Brasilia.

UNESCO - Organização das Nações Unidas para a Educação, a Ciência e a Cultura 


\section{Sumário}

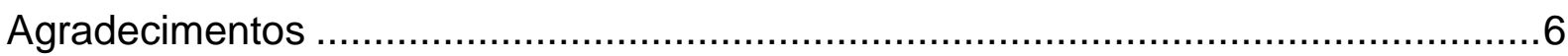

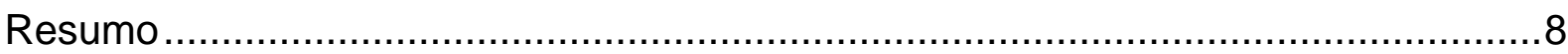

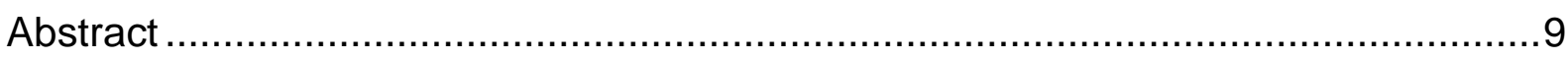

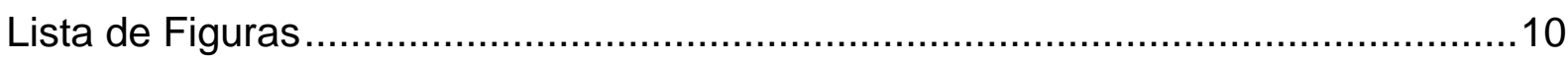

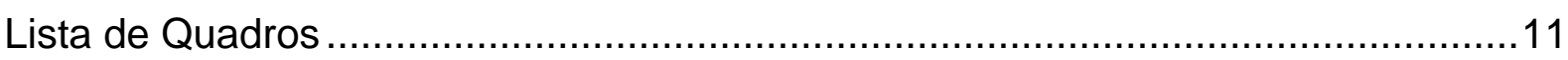

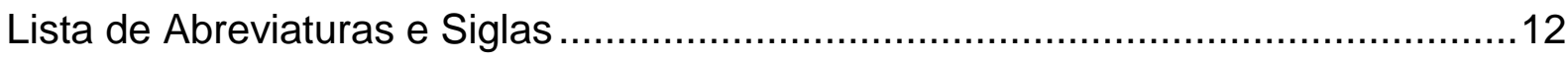

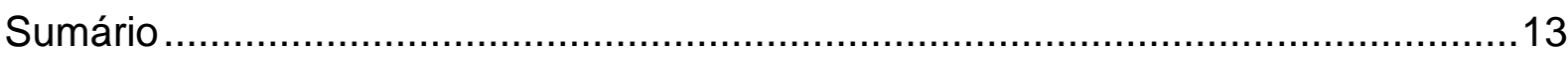

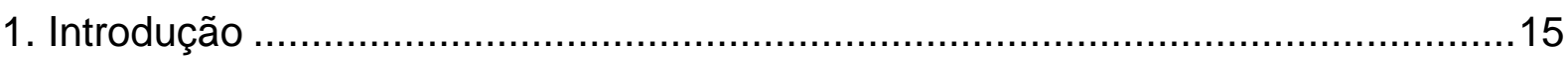

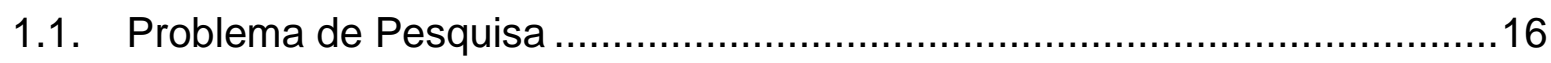

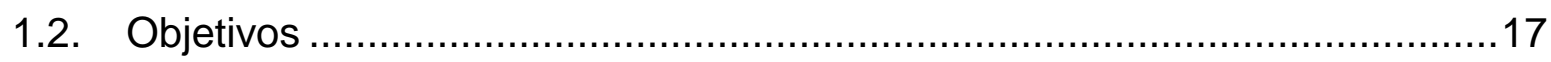

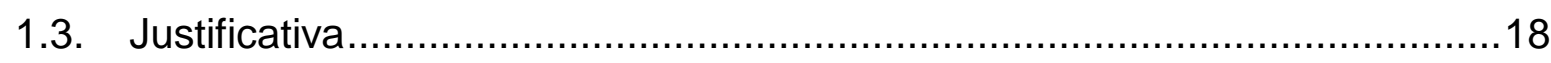

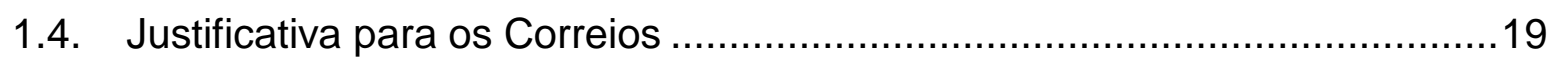

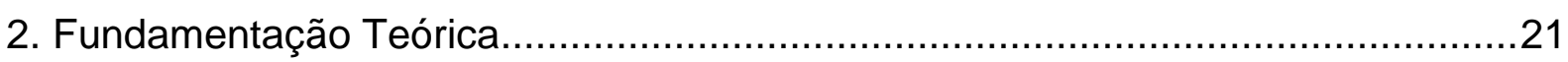

2.1. Documentação e Organização da Informação Museológica ..........................21

2.2. Análise e Representação da Informação - Documentação em Museus:

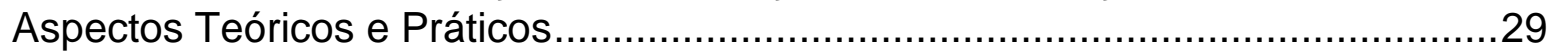

2.3. Estudos em Cultura Material: Análise e Representação da Informação de

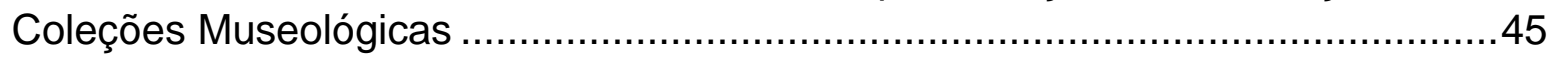

2.4. Museu de Ciência e Tecnologia: o Museu Correios......................................56

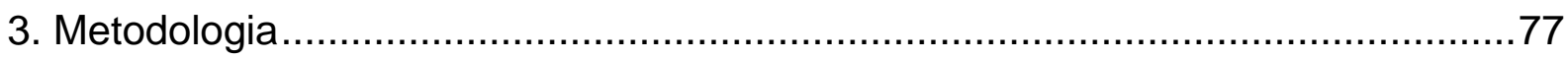

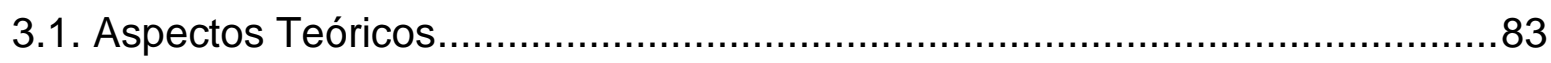

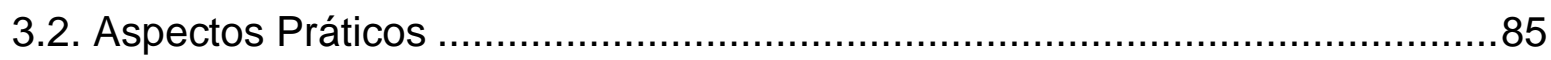

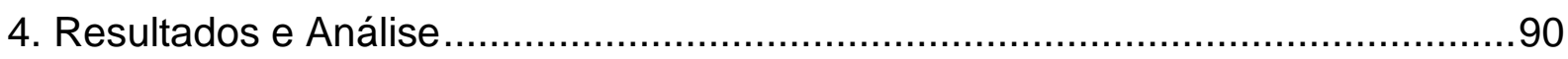

4.1. Análise do Sistema de Documentação da Coleção Telegráfica do Museu

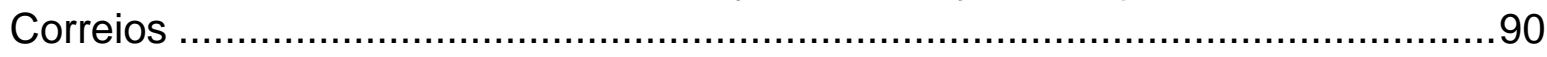

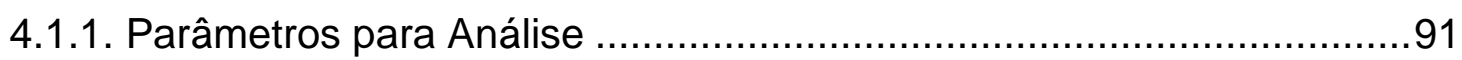

4.1.2. Estrutura de Dados (Data Structure)...................................................94

4.1.3. Procedimentos (Data Contents).........................................................99

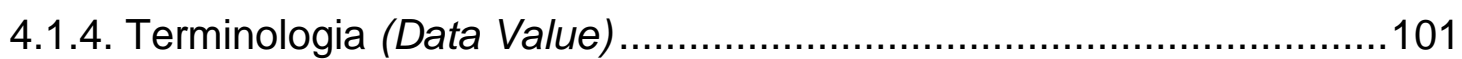

4.2. Descrição dos Estudos de Cultura Material ................................................104

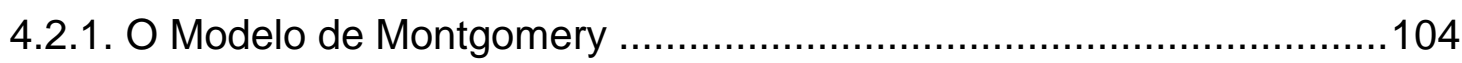

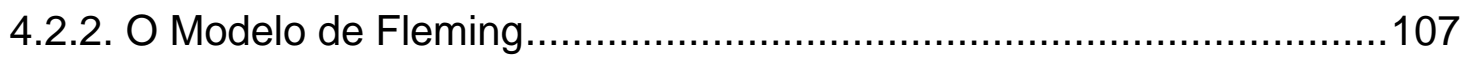

4.2.3. O Modelo de Prown .......................................................................111 


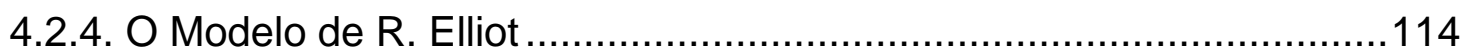

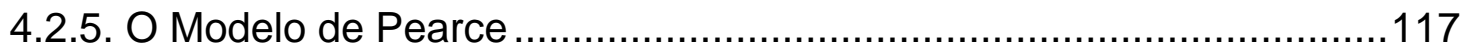

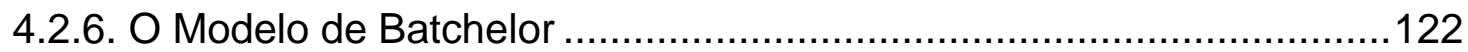

4.3. Análise Comparativa dos Estudos de Cultura Material ..............................124

4.3.1. Origem Disciplinar, Contexto e Aplicação em Âmbito Museológico ....124

4.3.2. Metodologia de Estudo de Objetos Propostas nos Modelos...............128

4.3.3. Níveis ou Camadas de Informação e Produtos .................................131

4.3.4. Aplicabilidade dos Modelos para Patrimônio de C\&T Musealizado ....134

4.4. Modelo Proposto pela Pesquisa..........................................................135

4.5. Aplicação do Modelo Proposto em uma Peça da Coleção Telegráfica ..........138

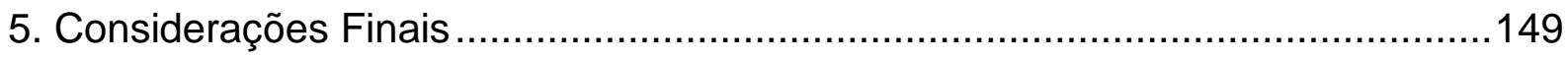

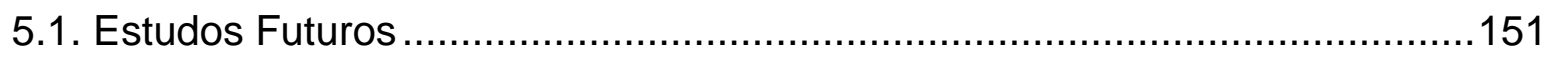

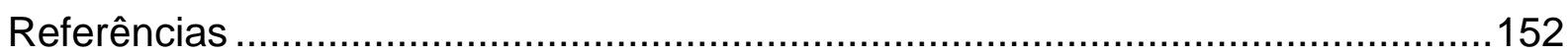

Anexo I - Ficha Catalográfica em Papel Criada na Década de 1970.....................158

Anexo II - Ficha Catalográfica Atualmente em Uso ..........................................160

Apêndice I - Proposta de Campos para Ficha Catalográfica para o Museu Correios 


\section{Introdução}

A pesquisa "Tratamento Informacional da Coleção Telegráfica do Museu Correios: análise sob a perspectiva científica, tecnológica e de cultura material" analisou modelos metodológicos, desenvolvidos no âmbito dos estudos de Cultura Material $^{1}$, para análise e representação da informação do patrimônio de ciência e tecnologia (C\&T) musealizado, mais especificamente a coleção telegráfica do Museu Correios (MC). A pesquisa teve como foco o tratamento informacional desse segmento do acervo do MC, tendo como objetivo principal indicar uma metodologia apropriada, baseada na análise dos métodos desenvolvidos por profissionais que se debruçam sobre a temática da Cultura Material. No que diz respeito aos aspectos práticos do resultado alcançado, a pesquisa busca indicar ferramenta que possibilite organização da informação desta parcela do acervo do Museu Correios, único em âmbito nacional que detém aspectos materiais e imateriais significantes da história do desenvolvimento tecnológico no Brasil.

O motivo que influenciou o desenvolvimento dessa pesquisa foi a necessidade de se estabelecer parâmetros que orientassem as atividades do Museu Correios, principalmente no que tange à Documentação em Museus. Essa motivação se justifica com a premissa do Código de Éticas para Museus do ICOM que identifica os museus como instituições, à serviço da sociedade, com função de salvaguarda ${ }^{2}$ do patrimônio para fins de educação e lazer.

Cabe ressaltar que a pesquisa incluiu a análise dos estudos desenvolvidos por profissionais de áreas como a Antropologia, a Museologia, a Etnografia, a História, a Sociologia e a Arqueologia, bem como os documentos normativos do Comitê Internacional para Documentação (CIDOC), do Conselho Internacional de Museus (ICOM), da Collections Trust $^{3}$ (Spectrum), e, em âmbito nacional, do Instituto Brasileiro de Museus (IBRAM) e do Museu de Astronomia e Ciências Afins (MAST), para alcançar o resultado aqui pretendido.

\footnotetext{
1 Os Estudos que a pesquisa se propõe a analisar foram referendados pela historiadora e profissional de museus inglesa Susan Pearce, cuja carreira profissional foi toda voltada para o estudo de coleções museológicas a partir do olha da Cultura Material.

2 Dentre as atividades que garantem a salvaguarda das coleções se encontra a Documentação em Museus.

${ }^{3}$ Órgão inglês que substituiu a Museum Documentation Association (MDA)
} 
No que tange aos conteúdos da Ciência da Informação, a presente pesquisa se insere nos processos de Organização da Informação em contexto museológico, uma vez que buscou desenvolver ferramenta para a análise, representação e posterior recuperação dos documentos - na concepção otletiana ${ }^{4}$ - e, consequentemente, da informação, desta faceta específica do acervo do Museu Correios.

Dessa forma, além de apresentar aspectos práticos, a pesquisa apresenta questões que favorecem o fortalecimento da teoria museológica, bem como do laço interdisciplinar entre a Museologia e a Ciência da Informação.

\subsection{Problema de Pesquisa}

O museu, enquanto instituição à serviço da sociedade, tem por objetivo a preservação, manutenção e comunicação do patrimônio, para fins de educação e lazer. E, buscando cumprir esse objetivo, o museu tem o dever de desenvolver metodologias que otimizem os processos inerentes à instituição, como a Conservação e a Documentação.

O Museu Correios é uma instituição ímpar no cenário museológico brasileiro por ter sob sua responsabilidade parte significativa da história das telecomunicações do Brasil e, consequentemente, parte do chamado Patrimônio de Ciência e Tecnologia.

Essa coleção, atualmente, não está sendo tratada de acordo com as normas técnicas elaboradas pelos órgãos responsáveis pela área. Dessa forma, verifica-se dificuldade no que tange à gestão, preservação e comunicação de uma faceta de seu acervo - a coleção telegráfica - se alinhando ao Plano Estratégico 2020 da Empresa.

Assim, partindo da premissa de que o museu deve, por meio de práticas documentais, coletar, analisar e representar a informação museológica, relevante para seus processos gerenciais, comunicacionais e de pesquisa, e que o Museu Correios possui uma coleção telegráfica, patrimônio de C\&T, únicos dessa tipologia

\footnotetext{
4 Paul Otlet, documentalista belga, identificou em seu livro Traité de Documentation, de 1934, o caráter documental dos objetos, ao afirmar que acervos museológicos são documentos ditos substitutos dos livros. (OTLET, 1934, p. 217)
} 
em âmbito nacional, qual dos modelos de análise de cultura material, indicados por Susan Pearce para utilização em instituições museológicas, é o mais indicado para tratamento informacional dos aparelhos que compõem essa coleção.

Os documentos analisados e indicados pela autora foram publicados nos livros Interpreting Objects and Collections (1994), Museum, Objects and Collections (1992), e Material Culture in Museums Studies (1989).

A pesquisa aqui apresentada não se limita às questões da práxis museológica. De forma concisa, a investigação vêm fortalecer a feição interdisciplinar da teoria da Museologia, em especial os pontos de comunicação entre a área e a Ciência da Informação.

\subsection{Objetivos}

Objetivo Geral:

Identificar qual modelo de cultura material, desenvolvidos para estudo de objetos musealizados, é o mais adequado para o tratamento informacional de coleções de Ciência e Tecnologia, buscando indicar ferramenta que auxilie o Museu Correios no que tange à gestão, preservação e comunicação da coleção telegráfica, e sanar as dificuldades do seu atual Sistema de Documentação.

\section{Objetivo Específico:}

Analisar o atual sistema de documentação do Museu Correios, em especial, o processo de análise da informação utilizado na documentação dos exemplares que compõem a coleção telegráfica, buscando identificar as dificuldades e problemas do sistema.

Analisar os modelos desenvolvidos pos C. Montgomery, E. M. Fleming, J. Prown, R. Elliot, S. Pearce e R. Batchelor, tendo como base parâmetros pré-estabelecidos pela pesquisa, a fim de verificar aplicabilidade em Museus de Ciência e Tecnologia, em especial no que tange à análise da informação - tema da gestão das coleções e da documentação em museus. 
Identificar, a partir da análise desenvolvida nos métodos, qual proposta de estudo de objetos possibilita aplicação na coleção telegráfica do Museu Correios.

Aplicar em um ítem da coleção a fim de verificar a efetividade do resultado da análise e ilustrar o trabalho a ser desenvolvido no Museu Correios.

\subsection{Justificativa}

A investigação é justificada pela necessidade de pensamento reflexivo e fortalecimento da teoria da Museologia. No caso da pesquisa "Tratamento Informacional da Coleção Telegráfica do Museu Correios: análise sob a perspectiva científica, tecnológica e de cultura material" a temática girou em torno dos aspectos da Documentação e Informação em Museologia.

As principais atividades em um Museu, o tripé que sustenta a instituição, são a conservação, a documentação (incluindo a pesquisa) e a comunicação. $O$ presente projeto se ambientou na Documentação em Museus e na Documentação em Museologia.

A Documentação em Museus é ação prevista no Código de Ética para Museus do Conselho Internacional de Museus (ICOM), que pontua:

2.20 - Documentação dos acervos: Os acervos dos museus devem ser documentados de acordo com normas profissionais reconhecidas. Esta documentação deve permitir a identificação e a descrição completa de cada item, dos elementos a ele associados, de sua procedência, de seu estado de conservação, dos tratamentos a que já foram submetidos e de sua localização. Estes dados devem ser mantidos em ambiente seguro e estar apoiados por sistemas de recuperação da informação que permitam o acesso aos dados por profissionais do museu e outros usuários autorizados. (INTERNATIONAL COUNCIL OF MUSEUMS, 2009, p.16, grifo nosso)

Assim, as instituições museológicas devem manter práticas normatizadas no que diz respeito à análise e representação das informações das coleções, incluindo suas especificidades, visando recuperação por usuários internos e externos, para fins administrativos e comunicacionais.

Por outro lado, e ainda em contexto teórico, a pesquisa buscou fortalecer a feição interdisciplinar da Museologia, em especial os pontos de interseção com a 
Ciência da Informação. Dessa forma, pode-se afirmar que o trabalho, no que diz respeito à atuação na chamada Organização da Informação e do Conhecimento (OIC), contribuiu para o fortalecimento dos estudos de Ciência da Informação em contexto museológico

No que tange às questões práticas da pesquisa buscou-se como resultado o desenvolvimento de um estudo analítico de métodos de tratamento informacional para indicação de ferramenta que possibilitasse análise e posterior organização da informação referente à coleção telegráfica do Museu Correios, de forma a transformá-los em documentos para pesquisas e processos comunicacionais. Vale ressaltar que a coleção telegráfica aqui objeto de estudo é composta por exemplares únicos e excepcionais e cuja grandeza não se conhece outra em nível nacional. Essa gama variada de objetos é capaz de 'contar' parte da história do sistema telegráfico no país por meio de conjuntos de instrumentos tecnológicos.

\subsection{Justificativa para os Correios}

Os Correios prevê em seu Plano Estratégico 2020, no capítulo de linhas de gestão, artigo referente à Responsabilidade Social, cuja alínea "u" aponta, como uma das ações previstas, o desenvolvimento e implantação de um modelo de gestão histórico-cultural. Essas ações são postas em prática, principalmente, nas suas Unidades Culturais: Museu Correios (DF), Centro Cultural Correios Rio de Janeiro (RJ), Centro Cultural Correios São Paulo (SP), Centro Cultural Correios Salvador (BA), Centro Cultural Correios Recife (PE), Espaço Cultural Correios Fortaleza (CE), Espaço Cultural Correios Juiz de Fora (MG), Espaço Cultural Correios Niterói (RJ) e Espaço Cultural Correios Porto Alegre (RS) ${ }^{5}$.

O Museu Correios, ambiente em que essa pesquisa se desenvolve, esta localizado em Brasília (DF). Além das atividades culturais patrocinadas pela empresa ${ }^{6}$, tem como missão coletar, conservar, preservar, pesquisar e divulgar os

\footnotetext{
${ }^{5}$ Em processo de oficialização.

6 Os Correios publica, anualmente, Edital para Sistema Aberto de Seleção para suas Unidades Culturais que prevê patrocínio para ações nas áreas: Artes Visuais, Artes Cênicas, Audiovisual, Humanidades e Músicas. Desse edital são selecionados projetos que ocuparão as salas expositivas e os espaços teatrais das Unidades Culturais da empresa.
} 
testemunhos materiais e imateriais da história dos Correios no Brasil para fins de educação e lazer.

A presente pesquisa buscou desenvolver ferramenta que auxilie o Museu Correios no que tange à gestão, preservação e comunicação de uma faceta de seu acervo - a coleção telegráfica - se alinhando ao Plano Estratégico citado. 


\section{Fundamentação Teórica}

\subsection{Documentação e Organização da Informação Museológica}

A Ciência da Informação $(\mathrm{Cl})$ é a área do conhecimento humano que se debruça sobre as questões referentes à produção, tratamento e disseminação da informação. Seus aspectos epistemológicos são amplamente estudados, já tendo sido caracterizada como ciência social e interdisciplinar (LIMA, D., 2003; PINHEIRO, 1997).

Apesar de sua nomenclatura ter sido utilizada pela primeira vez em meados do século $\mathrm{XX}$, estudo da $\mathrm{Cl}$ tem início no século XIX. O primeiro registro de um termo referente ao tratamento da informação, mais precisamente ao estudos dos livros e bibliotecas, se dá em 1802, com o termo Bibliografia. (ALVARES; ARAÚJO JUNIOR, 2010)

No entanto, a maior contribuição para a consolidação da área da $\mathrm{Cl}$ foi o desenvolvimento de uma corrente teórica e prática, em fins do século XIX, composta por princípios e métodos específicos de representação dos conteúdos dos diversos documentos, tendo por objetivo seu acesso: a Documentação.

A Documentação nasceu do chamado Movimento Bibliográfico, surgido no final do século XIX, início do XX, em Bruxelas, na Europa. Esse movimento tinha por objetivo encontrar alternativas e desenvolver ferramentas para organizar e possibilitar acesso a uma massa crescente de documentos produzidos.

Dentre os profissionais que fizeram parte desse movimento estavam dois advogados e políticos belgas, Paul Otlet (1868-1944) e Henri La Fontaine (18541943), mentores do Instituto Internacional de Bibliografia (IIB), criado em 1895, e do Repertório Bibliogáfico Universal (RBU). A IIB e a RBU foram criadas buscando concretizar o desejo de Otlet de dar acesso universal aos documentos produzidos. $O$ teórico afirmava que "o acesso ao conhecimento por todos os povos levaria a uma maior compreensão da concepção de alteridade, no sentido do conhecimento das diferenças, o que possibilitaria a paz mundial" (ORTEGA, 2009, p. 62).

A primeira menção ao termo Documentação por Otlet foi em 1903 com o sentido de processo de fornecer documentos e referências àqueles que precisam da informação contidas por eles. Verifica-se, então, que desde os primórdios da 
Documentação, Otlet já defendia que, a respeito do documento, sua função era mais importante que sua forma.

Em 1934, Otlet publicaria aquele que seria conhecido como a principal fonte científica para normatização das atividades documentais: o Traité de Documentation. Nesse livro, Otlet define os principais conceitos da nova disciplina - por exemplo, o conceito de documento - e identifica o que é o campo, suas funções, partes e processos, as instituições conhecidas como Organismos de Documentação, entre outros aspectos. Por fim, propõe uma rede universal de informação e documentação.

Inicialmente, Otlet afirma que o livro e o documento levaram o ser humano para a realidade da materialização do pensamento. Assim, o objeto da documentação seria o que ele chama de ser documentado. "O estudo do ser documentado requer, desse modo, uma ciência de caráter geral que atue como auxiliar das outras ciências". (SANTOS, 2007, p.59)

Para o autor, a Documentação é um conjunto de processos que tem por objetivo poder oferecer toda sorte de informação registrada em documentos: "[...] 10 universais quanto ao objeto; $2^{\circ}$ corretos e verdadeiros; $3^{\circ}$ completos; $4^{\circ}$ rápidos; $5^{\circ}$ atualizados; 60 fáceis de obter; $7^{0}$ reunido previamente e prontos para serem comunicados; $8^{\circ}$ postos à disposição de todos"' (OTLET, 1934, p.6-7, tradução nossa).

Para que seu objetivo fosse alcançado, Otlet afirma que o trabalho dos Organismos de Documentação deveria apresentar metodologia rigorosa que incluisse uma sistemática na formação da coleção, classificação, sistemas de representação da informação em fichas e catálogos, e sistemas específicos para acesso à informação.

Apesar de ter como foco os documentos bibliográficos e arquivísticos, definição clássica de documento com suporte em papel, o autor expande o entendimento do conceito, incluindo as coleções museológicas como fontes documentais:

\footnotetext{
7 [...] $1^{\circ}$ universelles quant à leur objet ; $2^{\circ}$ sûres et vraies ; $3^{\circ}$ complètes ; $4^{\circ}$ rapides ; $5^{\circ}$ à jour ; $6^{\circ}$ faciles à obtenis ; $7^{\circ}$ réunies d'avance et prêtes à être communiquées ; $8^{\circ}$ mises à la disposition du plus grand nombre.
} 


\section{Partes da Documentação}

$[\ldots]$

H. As coleções museográficas: são as amostras, espécimes, modelos, peças diversas, tudo que é útil à documentação mas que se apresenta como objetos tridimensionais. É documentação objetiva a ser tratada da mesma forma que as coleções bibliográficas e arquivísticas quanto à coleta, à catalogação e a classificação. (OTLET, 1934, p.6-7, tradução nossa) ${ }^{8}$

Otlet buscou um conceito de documento cuja foco de discussão fosse sua função, em detrimento de sua materialidade. De acordo com Smit, o documento, à época de Otlet, era intrinsecamente conectado à expressão do conhecimento humano o que levava ao entedimento de sua natureza como "[...] uma fonte de um conhecimento fixado materialmente, suscetível de ser usado para referência ou estudo, ou ainda como um argumento de autoridade." (SMIT, 2008, p. 12).

$\mathrm{Na}$ terminologia utilizada por Otlet para a classificação dos documentos, os objetos museológicos se encontram na categoria de documentos "substitutos dos livros".

Otlet define os substitutos do livro como aqueles meios para informar e comunicar algo cuja escrita não é o principal suporte. Dessa forma, entram nessa categoria os objetos de museus, maquetes, o telefone e o telégrafo, o meios de telecomunicação (rádio e televisão), o cinema, os discos, entre outros.

243. Documentos ditos « substitutos do livro »

a) $[\ldots]$ : o objeto de museu $[\ldots]$.

[...]

243.1. Objetos, material de demonstração

1. Noção

a) O documento escrito ou gráfico é a representação das coisas materiais ou das imagens intelectuais e abstratas das coisas. As coisas materiais em si (objetos) podem ser tidas como documentos uma vez que são criadas como elementos sensíveis, resultado de estudos, ou de provas de uma manifestação. É, então, 'documentação objetiva' e 'documentação automática'.

\footnotetext{
8 II Parties de la Documentation

[...]

H. Les collections muséographiques : Ce sont les échantillons, spécimens, modèles, pièces diverse, tout ce qui est utile à la documentation mais qui se présente comme objets à trois dimensions. C'est la documentation objective à traiter comme celle de la Bibliothèque et des archives quant au collectionnement, au catalogue et au classement.
} 
b) Os objetos de todas as espécies dão lugar à coleções. Assim, os objetos naturais: minerais (elementos e compostos químicos, rochas), plantas (ervas, madeiras, raízes), animais (anatomia, teratologia). Assim os objetos criados pelo homem: matéria, produtos, objetos técnicos. (OTLET, 1934, p.216-217, grifo nosso, tradução nossa) ${ }^{9}$

Otlet vai além na definição e inclui as instituições museológicas no conjunto da Documentação quando indica que nos museus "[...] as coisas reunidas por inteiro, ou amostras (parte de uma matéria homogênea) constituem documentos [...] e que são úteis ao estudo, ao ensino, à pesquisa" (OTLET, 1934, p.356, tradução nossa $)^{10}$ prevendo o que viria a ser posteriormente identificada como a aplicação da área no campo museológico ao afirmar que:

265.2 Museologia, Museografia

$[\ldots]$

b) Os museus apresentam em grande parte as mesmas questões que as bibliotecas: objetivos; organização; [...] administração; [...] operações (formação da coleção, catalogação, preparação, etiquetagem, inventário, catálogos, conservação, apresentação, demonstração). Museu, cartões de pesquisa, de documentação, de estudo, de difusão e de informação.

Os museus de objetos e a museografia encontram seu lugar na documentação, seja ao considerarmos as primeiras como parte integral da segunda, em sentido amplo, seja constituindo fontes auxiliares de informação, ou que certos princípios, certas metodologias, sejam comuns aos dois, seja ainda que existam estreitas conexões entre museus e bibliotecas. O museu é o livro in natura. (OTLET, 1934, p.356, tradução nossa) ${ }^{11}$

9243 Documents dits « Substituts du Livre »

a) [...] : l'objet dans le musée [...]. II y a là sous un certain rapport de substituts du livre,...

[...]

243.1 Objets, Materiel de démonstration

1. Notion

a) Le document écrit ou graphique est la représentation des choses matérielles ou des images intellectuelles et abstraites des choses. Les choses matérielles elle-mêmes (objets) peuvent être tenues pour documents lorsqu'elles sont érigées comme éléments sensibles, directs d'études, ou de preuves d'une démonstration. II s'agit alors de «documentation objective » et de «documentation automatique ».

b) Les objets de toute espèces donnent lieu a des collections. Ainsi les objets naturels: mineraux (éléments et composés chimiques, roches), plantes (herbes, bois, racines) animaux (antatomie, tératologie). Ainsi les objets créés par l'homme: matières, produits, objets techniques.

10 Les choses rassemblées en leur entier, ou par échantillon (partie d'une matière homogène) constituent des documents [...] et qui sont utiles à l'étude, à l'enseignement, à la recherche

11 "265.2 Muséologie, Muséographie

b) Les musées soulèvent en grande partie les mêmes questions que les bibliothèques: objet de but; organisation; [...]; Administration; [...] opérations (formation de collections, catalogue, préparation, étiquetage, inventaire, Catalogue, conservation, présentation, démonstration). Musée, cartes de recherche, de documentation, d'étude, de diffusion et d'information. 
E ainda que:

\subsection{Métodos}

O trabalho museográfico consiste: $1^{\circ}$ em reunir as peças; $2^{\circ}$ em determinar as peças; $3^{\circ}$ em classificar; $4^{\circ}$ em etiquetá-las; $5^{\circ}$ em elaboração de catálogo; 6으 em dedicar atenção especial às características de peças ou dos conjuntos; $7^{0}$ em organizar os objetos seja em reservas, seja em exposição e mostras em galerias públicas para para pesquisas; $8^{\circ}$ em organizar a divisão do trabalho da instituição." (OTLET, 1934, p. 358, tradução nossa) ${ }^{12}$

Smit (2008) identifica no tratado escrito por Paul Otlet um ideário que seria traduzido na linha mestra que orienta a área da Documentação e que até hoje se aplica aos campos que esta infuencia: o modelo analítico que objetiva a síntese das informações, ou seja, a elaboração de uma nova informação a partir dos dados disponíveis nos documentos que formam as coleções. Essa síntese repousa no que Otlet denominou de "princípio monográfico", ou seja, o isolamento das informações acerca de um mesmo tema. O que importa nesse princípio é a reunião de informações de um mesmo objeto que comporia um verbete numa enciclopédia universal.

O que Otlet busca é propor um modo de facilitar e agilizar o acesso à informação por meio da fragmentação do suporte que, ao ser reorganizado, proporciona unidade de conteúdo. Segundo Santos, percebe-se na proposta de Otlet um movimento duplo: "[...] desmaterialização e virtualização de documentos e sua transformação em informação nova, fruto de recombinação de informações, que comporão um novo documento" (SANTOS, 2007, p.62).

O trabalho desenvolvido por Paul Otlet no início do século XX se transformou na base para os estudos de diversos profissionais das áreas que comporiam, futuramente, a Ciência da Informação. Entre eles estava Suzanne Briet, bibliotecária francesa que, em 1951, escreve o manifesto Qu'est-ce que la documentation?.

Les musées d'objets et la museographie trouvent leur place dans la documentation, soit qu'on les considère comme une partie intégrale de celle-ci, au sens large, soit qu'ils constituent des sources auxiliaires d'information, soit que certains principes, certaines méthodes, soient communs à l'un ou à l'autre domaine, soit encore qu'il existe des connexions étroites entre musees et bibliothèques.

Le musée, c'est le livre in natura.

12265.5 Métodos

Le travail muséographique consiste: $1^{\circ}$ à réunir les pièces; $2^{\circ}$ à déterminer les pièces; $3^{\circ}$ à classer; $4^{\circ}$ à les étiqueter; $5^{\circ}$ à en dresser le catalogue; $6^{0}$ à consacrer une notice spéciale aux pièces caractéristiques ou à des ensembles; $7^{\circ}$ à disposer les objets soit en séries dites de magasin et de réserves, soit en exhibition et démonstration dans des galeries publiques pour les études; $8^{\circ}$ à organiser la division du travail de la coopération. 
Em seu texto Briet parte da definição de documento da União Francesa de Organismos de Documentação (UFOD) ${ }^{13}$, e propõe uma definição de documento: "[...] todo índice concreto ou simbólico, conservado ou registrado, com fins de representar, de reconstituir ou de provar um fenômeno ou físico ou intelectual" (BRIET, 1951, p.7, tradução nossa) ${ }^{14}$.

É a partir dessa definição de documento que Briet questiona:

Uma estrela é um documento? Um seixo carregado por uma corrente é um documento? Um animal vivo é um documento? Não. Mas são documentos as fotografias e os catálogos de estrelas, as pedras de um museu de mineralogia, os animais catalogados e expostos em um zoológico. (BRIET, 1951, p.7, tradução nossa) ${ }^{15}$

A partir dessas questões, Briet apresenta quatro aspectos essenciais para sua teoria da natureza do documento. Os documentos devem conter:

1- Materialidade: devem ser objetos ou sinais físicos;

2- Intencionalidade: devem ter a intenção de representar, evidenciar algo;

3- Processamento: os objetos devem passar por processos específicos, para serem documentos;

4- Fenomenologia: os objetos devem ser percebidos como documentos. (SMIT, 2008; BUCKLAND, 1997)

É possível verificar no texto de Briet que, para a autora, os documentos primários não são apenas documentos textuais tradicionais, incluindo em sua definição os objetos de museu e os seres vivos de Jardins Zoológicos e Botânicos.

O Conselho Internacional de Museus (ICOM), recém-criado na época da publicação do texto, já aparece no texto de Briet como órgão responsável para tratamento das coleções dos museus, instituições que salvaguardam toda espécie de unidades documentárias.

\footnotetext{
13 Documento é toda base de conhecimento, fixada materialmente, suscetível de ser utilizada para consulta, estudo ou prova. (ORTEGA, LARA, 2010)

${ }_{14}$ Tout indice concret ou symbolique, conservé ou enregistré, aux fins de représenter, de reconstituer ou de prouver un phénomène ou physique ou intellectuel.

15 Une étoile est-elle un document? Un galet roulé par un torrent est-il un document? Un animal vivant est-il un document? Non. Mais sont des documents les photographies et les catalogues d'étoiles, les pierres d'un musée de minéralogie, les animaux catalogués et exposés dans un Zoo.
} 
Posteriormente, outros dois autores, Meyriat e Buckland, também discutem o conceito de documento, trazendo duas novas teorias acerca de sua intencionalidade e de sua fisicalidade.

Meyriat (1981 apud COUZINET, 2004), afirma que a necessidade e a vontade de obter uma informação é um elemento imprescindível para que um objeto seja considerado documento. Assim, diferencia o "documento por intenção" e o "documento por atribuição". Essas duas categorias dialogam diretamente com a teoria de Otlet e Briet, uma vez que defende a possibilidade de qualquer objeto se tornar documento.

Buscando elucidar a diferença entre o documento por intecionalidade e por atribuição, Meyriat dá o seguinte exemplo:

Quando uma firma industrial produz e difunde um catálogo, ela o faz para comunicar para sua clientela informações sobre produtos, sua qualidade, seu preço; e esse documento é imediatamente reconhecido como tal. Mas ele pode posteriormente tornar-se 0 objeto de uma nova leitura por outros usuários, que buscarão outras informações, como a história dos preços, das técnicas de fabricação, dos hábitos de consumo, etc. Estes usuários são tão legítimos quanto os primeiros, ainda que não tenham sido previstos pelo autor do documento. (MEYRIAT, 1981 apud ORTEGA; LARA, 2010, n/p)

Buckland, também seguidor de Otlet e Briet, em texto e em capítulo de livro ambos publicados em 1991, discute a natureza da informação e seus três principais usos na literatura, a saber:

1. Informação-como-processo: quando alguém é informado. Nesse sentido 'informação' é o ato de informação, comunicar;

2. Informação-como-conhecimento: aquilo que é percebido na informação-comoprocesso, ou o conhecimento comunicado;

3. Informação-como-coisa: atribuído a objetos, como dados e documentos. A eles são atribuídos o termo informação por serem vistos como unidades informativas. (BUCKLAND, 1991a)

A terceira acepção do termo informação dialoga com o conceito de Otlet e Briet, uma vez que, segundo Buckland (1991b, p.352, tradução nossa), "qualquer representação tem necessariamente uma forma tangível (signo, sinal, dado, texto, filme, etc.) e então representações do conhecimento (e de eventos) são 
necessariamente 'informação-como-coisa'"16. Essa questão da tangibilidade ou intangibilidade é explicitada pelo autor, conforme Figura 1.

Figura 1 - Materialidade da Informação por Buckland

INTANGÍVEL

\begin{tabular}{|c|c|c|}
\hline ENTIDADE & $\begin{array}{l}\text { 2. Informação-como-conhecimento } \\
\text { Conhecimento }\end{array}$ & $\begin{array}{l}\text { 3. Informação-como-coisa } \\
\text { Dados, Documentos }\end{array}$ \\
\hline ROCESSO & $\begin{array}{c}\text { 1. Informação-como-processo } \\
\text { Ser informado de... }\end{array}$ & $\begin{array}{l}\text { 4. Processamento da Informação } \\
\text { Processamento de Dados }\end{array}$ \\
\hline
\end{tabular}

TANGÍVEL

Fonte: adaptado de Buckland, 1991b, p. 352

Segundo o autor existe a intenção do usuário ser informado (processo) e de uma mudança cognitiva (conhecimento). No entanto, "[...] os meios fornecidos, o que é manipulado e sobre o que se opera, o que é armazenado e recuperado é informação física (informação-como-coisa)". (BUCKLAND, 1991a, p.352, tradução nossa) $)^{17}$.

Uma vez entendido que documentos, ou informação registrada, necessariamente tem natureza tangível, o autor inclui os objetos de museu na categoria de unidades informativas, ou informação-como-coisa. Com essa visão objetos não são vistos como documentos tradicionais, mas podem se tornar quando processados com intenção informativa: "[...] objetos informativos são selecionados, coletados, organizados, descritos, recuperados, expostos e interpretados para que o conhecimento aumente e seja disseminado". (BUCKLAND, 1991b, p.35, tradução nossa) ${ }^{18}$

Assim, ao lado do Arquivo e da Biblioteca, o Museu é considerado instituição de estudo para a $\mathrm{Cl}$, uma vez que representa tipologia de sistema de informação

\footnotetext{
${ }^{16}$ Any such representation is necessarily in tangible form (sign, signal, data, text, film, etc.) and so representations of knowledge (and of events) are necessarily 'information-as-thing

17 But the means provided, what is handled and operated upon, what is stored and retrieved, is physical information (information-as-thing).

18 Informative objects are selected, collected, arranged, described, retrieved, displayed, and interpreted so that knowledge may be increased and disseminated
} 
com características únicas, como a natureza de suas unidades informacionais (itens da coleção) e a atribuição de valor documental ao objetos.

De acordo com Lima o museu

[...] sob a forma de estratégia pós-moderna de apresentação do conhecimento [...], representando área de aplicação e de interesse particular para a $\mathrm{Cl}[$ [...] permite associar o trabalho de construção e transferência da informação realizado pela Documentação e Informação em Museus, no campo da Ciência da Informação. (LIMA, D., 2008, p.6)

Conforme verificado acima, a aplicação da área da Documentação no campo museológico, dos processos de análise e representação da informação, se configura no âmbito da chamada Documentação e Informação em Museus, que será explanado no ponto 2.2. do presente trabalho.

\subsection{Análise e Representação da Informação - Documentação em Museus: Aspectos Teóricos e Práticos}

Uma vez que os objetos são selecionados para fazer parte de coleções museológicas, eles agregam um novo valor: o valor documental. Ou seja, eles passam a ser considerados documentos, fontes de informação.

É importante lembrar que, diferentemente das coleções bibliográficas e dos fundos arquivísticos, os objetos que compõem as coleções museológicas não são, em seu contexto primário, feitos para serem documentos. Se encaixam, então, na categoria que Meyriat (apud COUZINET, 2004) denomina de documentos por atribuição.

Além da questão da intencionalidade, cabe verificar que as unidades informacionais do museu também diferem em sua fisicalidade: não são documentos de papel, mas objetos, sejam naturais ou artificiais.

Os objetos, como previsto no código de ética são, testemunhos primários (ICOM, 2013), ou seja, objetos-documentos na medida em que atuam com função de comunicação dos "processos sociais e peculiaridades de caráter expressivos" (LIMA, D., 2008, p. 37). Os objetos são portadores de dados, devendo ser tomados, então, como unidades informacionais ligadas "[...] ao 'sistema de relações sociais de produção, circulação e consumo simbólicos" (LIMA, D., 2008, p. 37). 
Ainda sobre o caráter documental dos objetos museológicos, Pomian cria 0 termo objetos semióforos indicando que todos esses constructos apropriados e capazes de portar um significado estabelecem "[...] uma mediação de ordem existencial [...] entre o visível e o invisível, outros espaços e tempos, outras faixas de realidade" (POMIAN, 1984, p. 71). O conceito traz, ainda, aspectos do objetotestemunho-documento, ou seja, prova, se aproximando do significado etimológico da palavra.

Ainda a respeito do caráter informacional dos objetos, o historiador Jacques Le Goff, citando o também historiador Lucien Febvre, pontua que

a história faz-se com documentos escritos, sem dúvida. Quando existem. Mas pode fazer-se, deve fazer-se sem documentos escritos, quando não existem. Com tudo o que a habilidade do historiador lhe permite utilizar para fabricar seu mel, na falta das flores habituais. Logo, com palavras. Signos, paisagens e telhas. Com as formas do campo e das ervas daninhas. Com eclipses da lua e a atrelagem dos cavalos de tiro. Com os exames de pedras feitos pelos geólogos e com as análises de metais feitas pelos químicos. Numa palavra, com tudo o que, pertencendo ao homem, exprime o homem, demonstra a presença, a atividade, os gostos e as maneiras do ser do homem. (FEBVRE apud LE GOFF, 1994, p. 540)

A chamada Musealização é a operação de "[...] extrair, fisicamente ou conceitualmente, uma coisa de seu meio natural ou cultural de origem e dá-la um status museal" (DESVALLÉS; MAIRESSE, 2011, p. 251, tradução nossa) ${ }^{19}$. Nesse processo, os objetos são retirados de seu contexto para serem estudados como "[...] documentos representativos da realidade que os constituía" (DESVALLÉS; MAIRESSE, 2011, p. 251, tradução nossa) ${ }^{20}$.

No entanto, para que objetos e todo o seu espectro informacional possam ser utilizados na produção de conhecimento, função básica de centros de documentação, é imperativo que passem pelos processos da chamada Documentação em Museus.

A Documentação em Museus é uma aplicação da teoria da Documentação à prática museológica. Todos os processos do chamado Ciclo da Informação (ver figura 1), desenvolvidos no âmbito da Biblioteconomia e da Ciência da Informação,

\footnotetext{
${ }^{19}$ La muséalisation est l'opération tendant à extraire, physiquement et conceptuellement, une chose de son milieu naturel ou culturel d'origine et à lui donner un statut muséal [...].

${ }^{20}$ [...] des objets ou des choses (vraies choses) sont séparés de leur contexte d'origine pour être étudiés comme documents représentatifs de la réalité qu'ils constituaient.
} 
são adaptados à realidade dos Museus. Ou seja, é no âmbito da Documentação que se desenvolvem as atividades nomeadas de Inventário, Catalogação e Indexação, que serão, mais a frente, identificadas e explicitadas.

Figura 2 - Ciclo da Informação
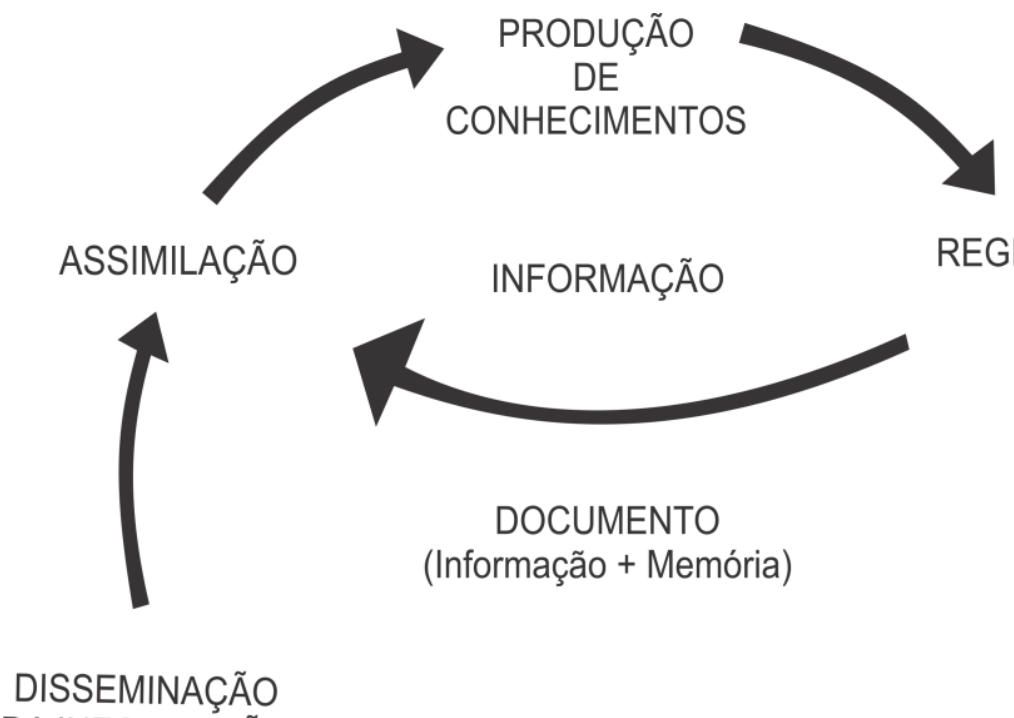

DA INFORMAÇÃO
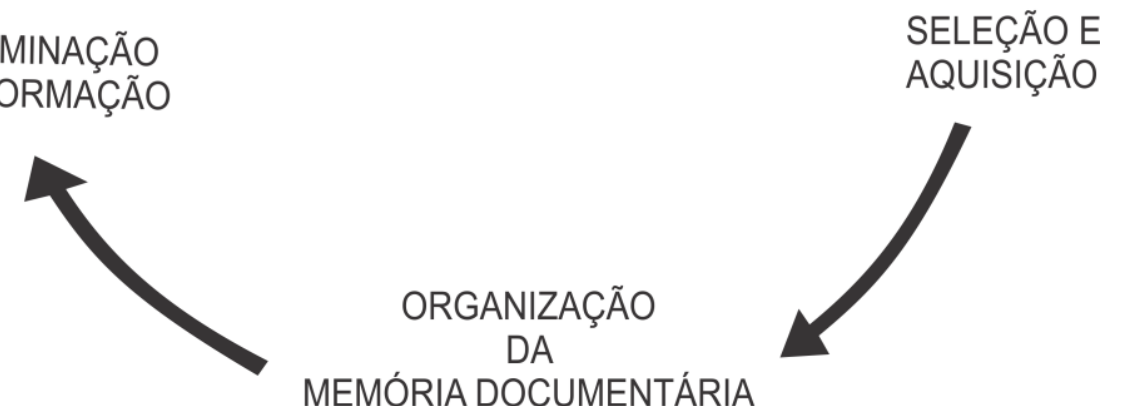

MEMÓRIA DOCUMENTÁRIA

Fonte: Dodebei, 2002, p. 25

As atividades relacionadas à Documentação em Museus se configuram no território da análise das coleções e produção de conhecimento, "[...] que possibilitará a um objeto preservado na asséptica prateleira da reserva técnica ter voz numa exposição e ser efetivamente um elo no processo de transmissão cultural" (GUEDES, 2010, p. 210).

A Documentação em Museus definida como o "[...] conjunto de informações sobre cada um dos seus itens [dos itens da coleção] e, por conseguinte, a representação destes por meio da palavra e da imagem (fotografia)" (FERREZ, 1994, p. 65). Com relação aos itens da coleção abrangem os "[...] objetos museológicos (termo extensivo também aos elementos e espaços construídos e aos espaços naturais musealizados de facetas variadas)" (LIMA, D., 2003, p.14) e, também, os passíveis de musealização. 
A Documentação, incluindo todos os seus processos, está intrinsecamente ligada aos temas da segurança e da produção de conhecimento ao

[...] proceder à identificação e reconhecimento do perfil físico; à determinação do caráter de propriedade e guarda (registro numerado); c) à idoneidade dos antecedentes da procedência/aquisição (tema da profilaxia contra o roubo -- tráfico ilícito e mercado clandestino de bens culturais); à gestão do patrimônio: (a) no local da posse/guarda ou fora dele (indicadores da localização física e de conferência quantitativa das peças), (b) quanto à sua preservação. (LIMA; ARRIBADA, 2008, n/p)

E, na produção de conhecimento, faz-se presente em

[...] razão da descrição que realiza associada à interpretação dos dados coletados, [...] Isto se explicita pela Documentação aplicada à Museologia fornecer, a partir dos seus resultados, todo um aparato a contribuir para elaboração de diversificados catálogos e outras publicações, bem como novas pesquisas acerca dos Bens musealizados. (LIMA; ARRIBADA, 2008, $\mathrm{n} / \mathrm{p}$ )

O Comitê Internacional para Documentação (CIDOC) ${ }^{21}$, criado em 1950, e um dos trinta comitês internacionais que fazem parte do Conselho Internacional de Museus (ICOM), define a Documentação como

[...] os registros que documentam a criação, história, aquisição pelo museu, e história subseqüente de todos os objetos em uma coleção museológica. Estes registros incluem procedência e documentos de origem, documentos de aquisição, condition reports [relatórios de conservação], registros catalográficos, imagens, e documentos de pesquisa, ambos criados pela instituição responsável e pelos donos anteriores ou por pesquisadores independentes, etc. (CIDOC, 1995, $\mathrm{n} / \mathrm{p}$, tradução nossa) ${ }^{22}$

De acordo com o mesmo órgão (CIDOC, 1995b), a Documentação objetiva:

1) "Assegurar a Responsabilidade com os objetos" 23 (tradução nossa) - a documentação desenvolve arquivo que atua como 'mapa' para o controle físico das peças e sua localização (Inventário).

${ }^{21} \mathrm{O}$ CIDOC, cabe esclarecer, agrega profissionais de museus que são, também, da área da informação e, ainda, muitos de seus participantes além de integrarem o ICOM são participantes da ASIST, Sociedade Americana para Ciência e Tecnologia da Informação.

22 The records which document the creation, history, acquisition by the museum and subsequent history of all objects in a museum collection. Such records include provenance and provenience documents, acquisition documents, conservation reports, cataloguing records, images, and research papers, both created by the holding institution and by previous owners or independent researchers, etc.

${ }^{23}$ Ensure accountability for objects. 
2) "Auxiliar na segurança das peças" 24 (tradução nossa) - ao desenvolver as listas e dossiês o museu tem controle do que possui. Em caso de roubo estes documentos auxiliam na sua recuperação.

3) "Prover um arquivo histórico sobre os objetos" 25 (tradução nossa) processo de 're-conhecimento' e leitura das informações físicas e contextuais que os objetos são portadores e sua posterior representação em fichas catalográficas (Catalogação).

4) "Suporte físico e acesso intelectual aos objetos" 26 (tradução nossa) - os processos da Documentação configuram análise da coleção e, por conseguinte, se ambientam na transmissão de conhecimento.

A Museums and Gallery Commission (MGC) foi o principal órgão público do Reino Unido responsável pelas políticas museológicas. Foi substituído em abril de 2000 pelo Musems, Library and Archives Council (MLA), extinto em 2012. Seus trabalhos estão, atualmente, sobre a responsabilidade do Arts Council England (ACE). Em seus manuais o MGC afirmava que a Documentação envolve todos os registros do museu bem como as informações a ele relacionadas.

Um museu sem qualquer documentação é inútil: não pode provar que possui suas coleções; não pode contabilizar aos doadores o que foi dado, ou aos auditores o que foi comprado, não pode manter segurança apropriada; e provavelmente destruiu a maior parte do valor histórico e cientifico de suas coleções. (MGC, 1995, p.49, grifo nosso, tradução nossa). ${ }^{27}$

Todas as atividades das instituições museológicas e afins são regidas por normas de conduta previamente estabelecidas. Assim, a Documentação - sendo uma dessas atividades - é prevista no Código de Ética para Museus do ICOM, no tópico 2 que pontua:

2 - Museus mantêm coleções em benefício da sociedade e de seu desenvolvimento.

\footnotetext{
${ }^{24}$ Aid the security of objects.

${ }^{25}$ Provide an historic archive about objects. Ibidem.

${ }^{26}$ Support physical and intellectual access to objects.

${ }^{27}$ A museum without any documentation is useless: it cannot legally prove that it owns any of its collections; it cannot account to donors for what has been given, or to auditors for what has been bought; it cannot maintain proper security; and it has probably destroyed most of the historical and scientific value of its collection.
} 
Princípio:

Museus têm o dever de adquirir, preservar e promover suas coleções como contribuição na salvaguarda do patrimônio natural, cultural e científico. Suas coleções são significantes heranças públicas, têm posição especial na lei e são protegidas por legislação internacional. Inerente a essa guarda pública há a noção de administração que inclui direitos de propriedade, permanência, documentação, acessibilidade e transmissão responsável. (ICOM, 2013, p. 2, grifo nosso, tradução nossa) ${ }^{28}$

Novamente, as regras éticas expostas no item 2.20 do Código de Ética da Museologia apontam para necessidade da prática da Documentação no trato das coleções, destacando a função de disseminação desta informação especializada para o público profissional e o público leigo.

As coleções de museus devem ser documentadas de acordo com normas profissionais aceitas. Essa documentação deve incluir identificação completa e descrição de cada item, suas associações, procedência, condição [de conservação], tratamento e presente localização. Esses dados devem ser guardados em locais seguros e serem amparadas por sistemas de recuperação promovendo o acesso às informações por profissionais do museu ou outro usuários legais. (ICOM, 2013, p. 5, grifo nosso, tradução nossa) ${ }^{29}$

Em âmbito nacional, em 2009 foi criado o Instituto Brasileiro de Museus (IBRAM) cuja função é a de normalizar e fiscalizar o patrimônio museológico brasileiro. No mesmo ano, foi sancionada a Lei $\mathrm{n}^{0}$ 11.904, de 14 de janeiro, onde é instituido o Estatuto dos Museus.

Nessa lei, a Documentação aparece, de forma significativa, em duas subseções, a saber:

\section{Subseção II \\ Do Estudo, da Pesquisa e da Ação Educativa}

Art. 28. O estudo e a pesquisa fundamentam as ações desenvolvidas em todas as áreas dos museus, no cumprimento das suas múltiplas competências.

\footnotetext{
28 Museums have the duty to acquire, preserve and promote their collection as a contribution to safeguarding the natural, cultural and scientific heritage. Their collections are significant public inheritance, have a special position in law and are protected by international legislation. Inherent in this public trust is the notion of stewardship that includes rightful ownership, permanence, documentation, accessibility and responsible disposal

29 Documentation of Collections: Museum collections should be documented according to accepted professional standard. Such documentation should include a full identification and description of each item, its association, provenance, condition, treatment and present location. Such data should be kept in a secure environment and be supported by retrieval systems providing access to the information by the museum personnel and other legitimate users
} 
§ 10 O estudo e a pesquisa nortearão a política de aquisições e descartes, a identificação e caracterização dos bens culturais incorporados ou incorporáveis e as atividades com fins de documentação, de conservação, de interpretação e exposição e de educação.

[...]

\section{Subseção IV}

Dos Acervos dos Museus

Art. 39. É obrigação dos museus manter documentação sistematicamente atualizada sobre os bens culturais que integram seus acervos, na forma de registros e inventários.

$\S 10$ O registro e o inventário dos bens culturais dos museus devem estruturar-se de forma a assegurar a compatibilização com 0 inventário nacional dos bens culturais.

$\S 20$ Os bens inventariados ou registrados gozam de proteção com vistas em evitar o seu perecimento ou degradação, a promover sua preservação e segurança e a divulgar a respectiva existência.

Art. 40. Os inventários museológicos e outros registros que identifiquem bens culturais, elaborados por museus públicos e privados, são considerados patrimônio arquivístico de interesse nacional e devem ser conservados nas respectivas instalações dos museus, de modo a evitar destruição, perda ou deterioração. (BRASIL, 2009, n/p)

Outro dado importante é que na mesma lei já era previsto o Inventário Nacional de Bens Culturais Musealizados (INBCM), mesmo que com pouca evidência:

Art. 41. A proteção dos bens culturais dos museus se completa pelo inventário nacional, sem prejuízo de outras formas de proteção concorrentes.

$\S 10$ Entende-se por inventário nacional a inserção de dados sistematizada e atualizada periodicamente sobre os bens culturais existentes em cada museu, objetivando a sua identificação e proteção.

§ 20 O inventário nacional dos bens dos museus não terá implicações na propriedade, posse ou outro direito real.

§ 30 O inventário nacional dos bens culturais dos museus será coordenado pela União.

§ 40 Para efeito da integridade do inventário nacional, os museus responsabilizar-se-ão pela inserção dos dados sobre seus bens culturais. (BRASIL, 2009, n/p)

O Inventário Nacional toma corpo legal com o Decreto 8.124, de 17 de outubro de 2013, que regulamenta os dispositivos da Lei 11.904 de 2009. Além de 
reiterar todos os pontos previsto na lei de 2009, na nova legislação, o INBCM é instituído:

\section{CAPÍTULO IV \\ DO INVENTÁRIO NACIONAL DOS BENS CULTURAIS MUSEALIZADOS}
Art. 11. Fica instituído o Inventário Nacional dos Bens Culturais Musealizados - Inventário Nacional, instrumento de proteção e preservação do patrimônio museológico, a ser coordenado pelo IBRAM, para os fins previstos no art. 41 da Lei n 11.904, de 2009.

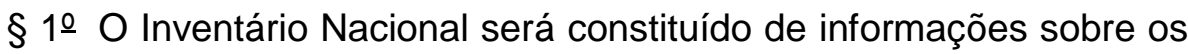
acervos dos museus brasileiros, públicos ou privados, fornecidas diretamente pelos museus.

$\S 2$ ㅇ Após o envio inicial das informações, os museus atualizarão periodicamente a situação de seu patrimônio perante o Inventário Nacional, por meio da inclusão dos bens adquiridos e descartados nos doze meses anteriores.

Art. 12. A inclusão de informações dos acervos dos museus brasileiros no Inventário Nacional não implica qualquer restrição quanto à propriedade, posse ou a qualquer outro direito real sobre os seus bens. (BRASIL, 2013, n/p)

O IBRAM, em 02 de agosto em 2014, e visando padronizar as informações do acervo museológico e inclusão na base de dados do INBCM, baixa a Resolução Normativa $n^{\circ}$ 2. Nesse documento o Instituto estabelece os campos de descrição das informações sobre os acervos museológico, bibliográfico e arquivístico que devem ser declarados no INBCM, em consonância com o Decreto no 8.124, afirmando, também, que esse sistema não substitui os outros instrumento de documentação já indicados na legislação.

Art. 4ํ - Para fins de identificação do bem cultural musealizado no INBCM, os elementos de descrição que deverão compor as Informações no preenchimento da declaração do inventário, de acordo com as especificidades das áreas da Museologia, da Biblioteconomia e da Arquivologia, são os seguintes:

I - Elementos de descrição para identificação do bem cultural de caráter museológico:

a) número de registro - informação obrigatória do registro individual definido pelo museu para identificação e controle do objeto dentro do acervo;

b) outros números - informação facultativa de numerações anteriores atribuídas ao objeto, tais como números antigos e números patrimoniais;

c) situação - informação obrigatória da situação em que se encontra o objeto, o seu status dentro do acervo do museu, com a marcação das opções: 1- localizado; 2 - não localizado; 3 - excluído; 
d) denominação - informação obrigatória do nome que identifica o objeto;

e) título - informação facultativa da denominação dada ao objeto atribuído pelo autor, curador ou pelo profissional da documentação;

f) autor -: informação obrigatória do nome do autor do objeto (individual ou coletivo);

g) classificação - informação facultativa da classificação do objeto segundo 0 "Thesaurus para Acervos Museológicos ou outros vocabulários controlados;

h) resumo descritivo - informação obrigatória do resumo da descrição textual do objeto, apresentando as características que o identifique inequivocamente e sua função original;

i) dimensões - informação obrigatória das dimensões físicas do objeto, considerando-se as medidas bidimensionais (altura $x$ largura); tridimensionais (altura $\mathrm{x}$ largura $\mathrm{x}$ profundidade); circulares (diâmetro $x$ espessura) e peso;

j) material / técnica - informação obrigatória dos materiais do suporte que compõem o objeto, hierarquizando sempre a sua maior área confeccionada/manufaturada e a técnica empregada na sua manufatura;

k) estado de conservação - informação obrigatória do estado de conservação em que se encontra o objeto na data da inserção das informações;

I) local de produção - informação facultativa da indicação geográfica do local onde o objeto foi confeccionado;

m) data de produção - informação facultativa da data ou período de confecção/produção/manufatura do objeto;

n) condições de reprodução - informação obrigatória com a descrição das condições de reprodução do objeto, indicando se há alguma restrição que possa impedir a reprodução/divulgação da imagem do objeto nos meios ou ferramentas de divulgação;

o) mídias relacionadas - informação facultativa acerca da inserção de arquivos de imagem, sons, vídeos e/ou textuais relacionados ao objeto. (BRASIL, 2014, n/p)

Apesar de estar presente no principal documento normativo do ICOM e em legislação nacional, muitos museus salvaguardam coleções mal documentadas, que perderam muita de sua utilidade por falta de informação. A documentação, então, se faz essencial para a gestão das coleções, para formulação de políticas de aquisição e para a pesquisa e comunicação das coleções. Fernandez (2010, p. 159) afirma que "[...] o museu é essencialmente um centro de documentação, onde se investiga e organiza a informação".

Souza $(2009, \mathrm{n} / \mathrm{p})$ verifica que "[...] os insuficientes recursos empreendidos com a informação/documentação é conseqüência do não conhecimento do potencial 
do museu como um 'sistema de informação'”. Um sistema total de informação em museus depende da Documentação e demanda uma análise aprofundada das necessidades informacionais do Museu.

A enorme e variada gama de ferramentas para consulta pelos diversos usuários do Museu, resultado dos processos documentais, foi listada por Bergengren, conforme quadro abaixo.

Quadro 1 - Ferramentas Informacionais em Museus

\begin{tabular}{|l|l|}
\hline \multicolumn{1}{|c|}{ TIPO DE INFORMAÇÃo } & \multicolumn{1}{c|}{ SUBSISTEMA DE INFORMAÇÃo } \\
\hline $\begin{array}{l}\text { Informação sobre os objetos do } \\
\text { museu }\end{array}$ & $\begin{array}{l}\text { Inventário, catálogos sistemáticos, catálogos } \\
\text { topográficos, catálogos por nome próprio das } \\
\text { pessoas que se relacionam com os objetos } \\
\text { (autores, doadores, etc), catálogos por material, } \\
\text { catálogos por técnica de produção, catálogos } \\
\text { cronológicos, catálogos de coleções de outros } \\
\text { museus, etc. }\end{array}$ \\
\hline Informações bibliográficas & $\begin{array}{l}\text { Inventário, catálogos por autor, catálogos por } \\
\text { título, catálogos analíticos, bibliografia }\end{array}$ \\
\hline $\begin{array}{l}\text { Informações sobre os arquivos } \\
\text { e documentos }\end{array}$ & $\begin{array}{l}\text { Inventário, catálogos de fontes por nomes } \\
\text { próprios, catálogos analíticos, catálogos } \\
\text { topográficos, catálogos de outros arquivos. }\end{array}$ \\
\hline $\begin{array}{l}\text { Informações sobre as pinturas } \\
\text { e fotografias }\end{array}$ & $\begin{array}{l}\text { Inventário, catálogos de autores, catálogos por } \\
\text { nomes de personagens representados, } \\
\text { catálogos sistemáticos/iconográficos, catálogos } \\
\text { cronológicos, catálogos de negativos, número } \\
\text { da obras/número do negativo no catálogo para } \\
\text { referência cruzada. }\end{array}$ \\
\hline $\begin{array}{l}\text { Informações sobre as } \\
\text { publicações do museu }\end{array}$ & $\begin{array}{l}\text { Bibliografia e catálogo de vendas } \\
\text { Catálogos de exposições, guias impresos, } \\
\text { pôsteres, etc., souvernis }\end{array}$ \\
\hline
\end{tabular}

Fonte: adaptado de Bergengren, 1978, p. 214

Como visto anteriormente, a Documentação é um conjunto de processos que busca analisar os dados dos itens que compõem o acervo, com funções, características e graus informacionais distintos. Esses processos acompanham o objeto museológico de sua coleta e entrada na instituição até seu uso em processos 
comunicacionais. (exposições, catálogos, etc.). De forma resumida, identificam-se como procedimentos documentais: o Registro, o Inventário, a Catalogação e a Indexação, evidenciados no quadro abaixo, que os identifica na definição da MGC (com exceção da indexação):

Quadro 2 - Processos Documentais na definição de Documentação da MGC

\begin{tabular}{|c|c|}
\hline Museums \& GALLERIES & ATIVIDADE RELACIONADA \\
\hline $\begin{array}{c}\text { [O Museu] não pode provar que possui } \\
\text { suas coleções }\end{array}$ & Registro \\
\hline $\begin{array}{c}\text { [O Museu] não pode contabilizar aos } \\
\text { doadores o que foi dado, ou aos } \\
\begin{array}{c}\text { auditores o que foi comprado, não pode } \\
\text { manter segurança apropriada }\end{array}\end{array}$ & Inventário \\
\hline $\begin{array}{c}\text { e provavelmente destruiu a maior parte } \\
\text { do valor histórico e cientifico de suas } \\
\text { coleções }\end{array}$ & Catalogação \\
\hline
\end{tabular}

Fonte: adaptado de Museums and Galleries Commission, 1995, p.49 30

O Registro é um termo originariamente da área do Direito e aplicado à Museologia para designar 0 ato de processar a entrada de um objeto no museu e na coleção. É caracterizado por não apresentar função classificatória e também por não gerar formulário (dossiês), sendo um processo de legalização ou um exercício de dar identidade ao objeto no momento de sua chegada à instituição, conferindo-Ihe caráter de pertencimento ou de exemplar sob responsabilidade do Museu. É o exercício do domínio que se formaliza na numeração seriada e sem partição atribuída ao objeto quando de sua entrada, e que corresponde à marcação na peça e à etiqueta. Se configura como processo legal e burocrático.

Após sua entrada legal, o objeto passa então por processos que irão analisar sua carga informacional. Peter van Mensch, profissional de museus e professor do curso de museus da Reinwardt Academy, que se debruçou sobre a natureza das informações das coleções museológicas, afirma que "[...] todo objeto tem um valor, seja intrínseco ou extrínseco, isto é, em conexão com outros objetos" (MENSCH,

\footnotetext{
${ }^{30}$ A museum without any documentation is useless: it cannot legally prove that it owns any of its collections; it cannot account to donors for what has been given, or to auditors for what has been bought; it cannot maintain proper security; and it has probably destroyed most of the historical and scientific value of its collection.
} 
1986, p. 36, tradução nossa) ${ }^{31}$, e ainda que "[...] uma lista inicial [desses valores] já demonstra as múltiplas possibilidade: científico, histórico, recreacional, estético, econômico, de valores éticos, etc." (MENSCH, 1986, p. 36, tradução nossa) $)^{32}$

Em uma primeira instância o valor de um objeto é determinado pela suas propriedades materiais [...]. 'Hardware' (informação intrínseca) e 'sofware' [sic] (documentação e informação contextual) juntos geram o 'testemunho' de um objeto. (MENSCH, 1986, p. 36, tradução nossa) $)^{33}$

O que o autor chama de hardware e software são os níveis de informação dos objetos, também conhecidos como informação intrínseca e extrínseca (MENSCH, 1986; FERREZ, 1994), do objeto e sobre o objeto (LIMA, D., 2003), ou ainda dados sintáticos e semânticos. (SOUZA, 2009).

Mensch desenvolveu uma abordagem que inclui três níveis de informação, a saber:

Quadro 3 - Modelo Informacional de Peter van Mensch

\begin{tabular}{|l|l|}
\hline \multicolumn{1}{|c|}{ Nível DA INFORMAÇÃo } & \multicolumn{1}{c|}{ CATEGORIAS DE INFORMAÇÃo } \\
\hline \multirow{2}{*}{ Propriedades Físicas } & Composição, Material \\
\cline { 2 - 2 } & Construção, Técnica \\
\cline { 2 - 2 } & $\begin{array}{l}\text { Morfologia (subdividida em formato e } \\
\text { dimensão; estrutura da superfície; cor/ } \\
\text { padrões de cor e imagem; texto) }\end{array}$ \\
\hline \multirow{2}{*}{ Função e Significado } & $\begin{array}{l}\text { Significado primário (significado funcional } \\
\text { e significado expressivo - valor } \\
\text { emocional) }\end{array}$ \\
\cline { 2 - 2 } & $\begin{array}{l}\text { Significado secundário (significado } \\
\text { simbólico, significado metafísico) }\end{array}$ \\
\hline
\end{tabular}

(continua...)

${ }^{31}$ Every object has a certain value, either instrinsic or extrinsic, i.e., in connection with other objects.

32 A tentative list already shows a multitude of possibilities: scientific, historical, recreational, aesthetical, economic, ethical values, etc.

33 In the first instance the value of an object is determined by its material properties. (...). 'Hardware' (intrinsic information) and 'sofware' [sic] (documentation and contextual information) together make an object 'testemony'. 
(continuação do quadro 03)

\begin{tabular}{|l|l|}
\hline \multirow{4}{*}{ História } & $\begin{array}{l}\text { Gênese (o processo no qual a idéia e a } \\
\text { matéria-prima são forjadas à forma) }\end{array}$ \\
\cline { 2 - 3 } & $\begin{array}{l}\text { Uso (primeira função - geralmente de } \\
\text { acordo com a intenção do criador; re- } \\
\text { utilização) }\end{array}$ \\
\cline { 2 - 3 } & $\begin{array}{l}\text { Deterioração (fatores endógenos e } \\
\text { exógenos) }\end{array}$ \\
\hline & Conservação e Restauração \\
\hline
\end{tabular}

Fonte: adaptado de Mensch, 1986, p.41

Esses níveis informacionais são trabalhados na chamada Análise e Representação da Informação, que inclui os processos de Pesquisa, Inventário, Catalogação e Indexação.

O Inventário é definido como a "[...] gestão da informação dos dados básicos de cada objeto da coleção, incluindo detalhes que são essenciais para as questões de responsabilidade e segurança" ${ }^{34}$ (CIDOC. 1995b, n/p, tradução nossa). O CIDOC entende por dados básicos como um modelo mínimo cujas informações sejam necessárias para identificação da obra, ou seja, dados referentes à sua descrição física, conservação e localização. Pode-se apontar entre modelos preconizados para segurança das coleções e assemelhados a Resolução Normativa ํㅡㄹ 2, do IBRAM, já apontada nesse ponto, e o documento Object ID disseminado internacionalmente.

O Object-ID - Guidelines for Making Records that Describe Art, Antiques, and Antiquities $^{35}$ é um projeto desenvolvido pela Fundação J. Paul Getty em parceria com a UNESCO e o ICOM. É um guia composto de nove categorias de informação indispensáveis para identificação física dos objetos (ver quadro na próxima página $)^{36}$, uma breve descrição e uma imagem, e que tem por objetivo principal documentar os objetos de forma a facilitar a procura e reconhecimento de obras de arte roubadas.

\footnotetext{
${ }^{34}$ Basic collection management information about each object in collection, including the details that are essential for accountability and security.

35 THORNES, Robin. DORRELL, Peter. LIE, Henry. Object-ID - Guidelines for Making Records that Describe Art, Anticues, and Antiquities. USA: J. Paul Getty Trust. ICOM/GETTY. 1999.

36 Para esse trabalho, preferiu-se manter, nos Quadro 04 e 05, os nomes em inglês, com sua tradução ao lado, possibilitando comparação no que tange à nomenclatura nas duas línguas.
} 
Quadro 4 - Categorias de Informação do Object ID

\begin{tabular}{|c|c|c|}
\hline & TeRMo ORIGINAL & TRADUção \\
\hline 1 & Type of Object & Tipo de Objeto \\
\hline 2 & Materials \& Techniques & Materiais e Técnicas \\
\hline 3 & Measurements & Medidas \\
\hline 4 & Inscriptions \& Markings & Inscrições e Marcas \\
\hline 5 & Distinguishing Feature & Detalhe para Distinção / \\
Características diferenciadoras
\end{tabular}

Fonte: adaptado de Thornes, 1999

Os dados previstos nas categorias do Object-ID são referentes à natureza física do objeto (dados intrínsecos) e se apresentam de fácil compreensão para que os leigos possam identificar as peças. O que aqui se denominou leigos, em relação às particularidades dos objetos museológicos, são os membros da Polícia Internacional (INTERPOL) que atuam na busca de obras de arte roubadas (temática do tráfico ilícito de bens culturais). A base de dados do Object-ID está presente nos computadores das aduanas nas fronteiras.

A Catalogação é o processo de coletar os dados intrínsecos e extrínsecos dos objetos e, a partir disto, passa a fornecer elementos para gerenciar toda a informação sobre as coleções e outros formatos musealizados. Os dados levantados são inseridos nas fichas catalográficas, procedendo, deste modo, ao registro das informações intrínsecas e extrínsecas do objeto. Esses dossiês são instrumentos que servem para informação que interpreta, na forma e conteúdo, o patrimônio museológico e está dirigida aos profissionais de museus, pesquisadores e demais interessados. 
O CIDOC desenvolveu, em 1995, um modelo completo para catalogação de acervos museológicos, o International Guidelines for Museum Object Information: the CIDOC Information Categories (IGMO) ${ }^{37}$.

O IGMO é descrito como conjunto de diretrizes propostas para se desenvolver uma catalogação completa. O manual, em sua introdução, identifica sua função e informa que os profissionais devem adequar os campos de informação propostos no documento ao tipo de acervo, devendo ser utilizado de forma a guiar o processo de descrição completa dos objetos. São propostos 74 campos de informação, divididos em 22 categorias de informação, dispostas em ordem alfabética, conforme quadro a seguir

Quadro 5 - Categorias de Inforção do IGMO (CIDOC)

\begin{tabular}{|c|c|c|}
\hline & TERMO ORIGINAL & TRADUÇÃo \\
\hline 1 & Acquisition information & Informação de aquisição \\
\hline 2 & Condition information & Informação de conservação \\
\hline 3 & Deaccession and disposal information & $\begin{array}{c}\text { Informação de baixa patrimonial e } \\
\text { alienação (descarte) }\end{array}$ \\
\hline 4 & Description information & Informação de descrição \\
\hline 5 & Image information & Informação de imagem \\
\hline 6 & Institution information & Informação de instituição \\
\hline 7 & Location information & Informação de localização \\
\hline 8 & Mark and inscription information & $\begin{array}{c}\text { Informação de marcas e } \\
\text { inscrições }\end{array}$ \\
\hline 9 & Material and technique information & Informação de material e técnica \\
\hline 10 & Measurement information & Informação de medidas \\
\hline 11 & Object association information & Informação de associação \\
\hline 12 & Object collection information & $\begin{array}{c}\text { Informação de coleções de } \\
\text { objetos }\end{array}$ \\
\hline
\end{tabular}

(continua...)

${ }^{37}$ Sigla não-oficial utilizada neste trabalho. 
(continuação do Quadro 05)

\begin{tabular}{|c|c|c|}
\hline 13 & Object entry information & Informação de entrada \\
\hline 14 & Object name information & $\begin{array}{c}\text { Informação de } \\
\text { nome/nomenclatura }\end{array}$ \\
\hline 15 & Object number information & Informação de número \\
\hline 16 & Object production information & Informação de produção \\
\hline 17 & Object title information & Informação de título \\
\hline 18 & Part and component information & $\begin{array}{c}\text { Informação de partes e } \\
\text { componentes }\end{array}$ \\
\hline 19 & Recorder information & Informação de registro \\
\hline 20 & Reference information & Informação de referëncia \\
\hline 21 & Reproduction rights information & Informação de direitos autorais \\
\hline 22 & Subject depicted information & Informação de tema \\
\hline
\end{tabular}

Fonte: adaptado de CIDOC, 1995b

Os 74 campos de informação funcionam como base para o desenvolvimento de sistemas de documentação exaustivos, ou seja, as informações intrínsecas e extrínsecas dos objetos estão representadas nestas categorias.

Cabe chamar atenção que, por conta do nível da informação coletada na Catalogação ser mais profundo, o trabalho "[...] envolve conhecimentos específicos do domínio da Museologia, da natureza/Área do Conhecimento da Coleção em questão, e, também, da Informação" (LIMA, D., 2008, p. 8).

E, por fim, a Indexação é o processo de atribuição de termos, também chamados de descritores ou palavras-chaves, que caracterizem de modo claro e sem dubiedade as informações relevantes que representam o documento. A Indexação é forma de imprimir rapidez e tornar mais eficaz a recuperação da informação. No caso dos museus, acerca das suas coleções e assemelhados, por meio de sistemas de organização do conhecimento (SOC's), como thesaurus e listas de termos controlados. 
No próximo ponto dessa revisão será dado maior enfoque aos processos de Pesquisa e Análise da Informação Museológica, foco dessa pesquisa, além de apresenta os conceitos de Cultura Material e os modelos de estudo do objeto.

\subsection{Estudos em Cultura Material: Análise e Representação da Informação de Coleções Museológicas}

A pesquisa em tela se concentrou nos processos de pesquisa e análise informacional, visando o desenvolvimento de ferramentas que auxiliassem nos processos de representação e recuperação da informação. A Figura 3 demonstra como a análise da informação é importante em Centros de Informação e como esse processo se faz presente em todos as atividades documentais:

Figura 3 - Análise da Informação e seu Papel no Ciclo Documentário

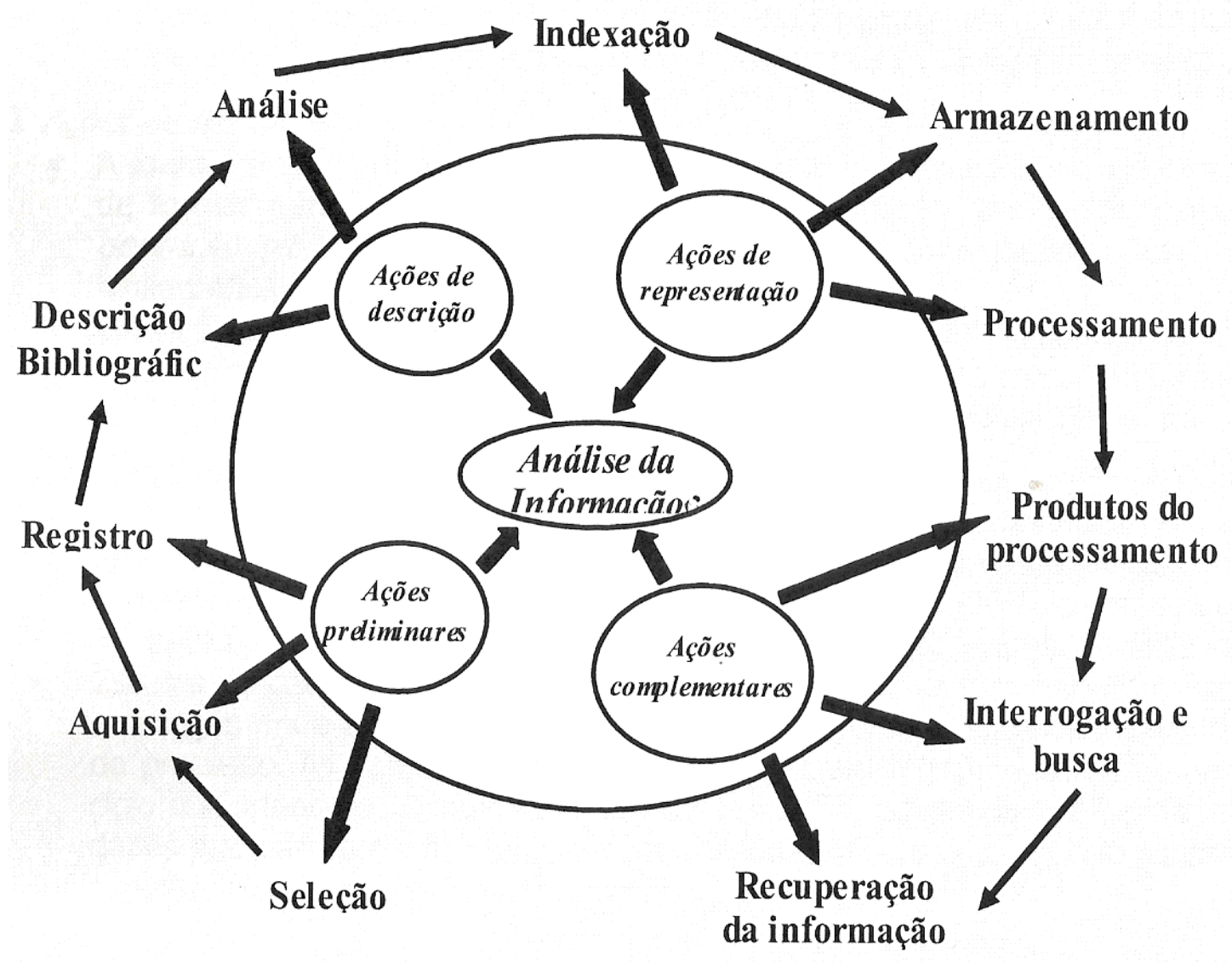

Fonte: Baptista; Araújo Jr.; Carlan, 2010

É possível inferir, então, que o processo de análise da informação é atividade primordial para que os objetivos a que se propõe a Documentação em Museus possam ser alcançados dentro das normas e padrões estabelecidos pela área. 
No entanto, não há, atualmente, metodologia específica para a Análise da Informação Museológica. Algumas instituições, como Museu de Astronomia e Ciências Afins (MAST), no Rio de Janeiro, já desenvolvem pesquisas para estabelecimento de um modelo para análise informacional de suas coleções. Para isso, recorreram aos estudos em Cultura Material.

O conceito de Cultura Material tem maior representatividade na Arqueologia, meio onde se desenvolveu na segunda metade do século XIX, mais precisamente em 1875. À época, os arqueólogos tiveram que lidar com todos os vestígios cuja documentalidade não estava expressa em documentos escritos. Para isso PittRivers $^{38}$, quem utilizou o termo Cultura Material pela primeira vez (BERGERON, 2011), elaborou um método de classificação das culturas baseado "[...] na comparação de formas, materiais, funcionalidades e características estéticas de objetos desprovidos de informação escrita" (BITTENCOURT, 1989, n/p) ${ }^{39}$.

Cultura Material tem, por definição, a "[...] manifestação da cultura por meio da produção material" (PROWN, 1993, p. 1, tradução nossa) ${ }^{40}$, ou seja, por meio de objetos. A premissa principal é a de que esses materiais

[...] refletem, consciente ou inconscientemente, direta ou indiretamente, as crenças dos indivíduos que os encomendam, os fabricam, os compram ou os usam e, por extensão, as crenças da sociedade à qual esses indivíduos pertencem. (PROWN, 1993, p. 1, tradução nossa) ${ }^{41}$

Assim, podemos afirmar que a Cultura Material estuda os objetos em seus contextos, como "[...] signos e símbolos exteriores das idéias particulares" (JULIEN; ROSSELIN, 2005, p. 13, tradução nossa) ${ }^{42}$, buscando demonstrar seu papel crucial como motores para mudança. Segundo Prown (1993), objetos são resultados de causas e materializam crenças: "[...] quando uma sociedade passa por alguma

\footnotetext{
${ }^{38}$ Apesar de desenvolver seus estudos no âmbito da Arqueologia, Pitt-Rivers era antropólogo.

39 Esse método irá influenciar nos trabalhos desenvolvidos pelos etnógrafos, historiadores e, mais contemporaneamente, pelos museólogos. Cabe ressaltar, também, que esse paradigma forneceu o modelo museográfico dos grandes museus enciclopédicos do século XIX que narravam a história da humanidade desde suas origens até o que eles chamavam de estágio mais avançado a partir da análise dos objetos. (SCHWARCZ, 1998)

40 Material culture is [...] the manifestation of culture through material productions.

41 [...] that human made objects reflect, consciously or unconsciously, directly or indirectly, the beliefs of the individuals who commissioned, fabricated, purchased, or used them and, by extension, the beliefs of the larger society to which these individuals belonged.

42 [...]des signes et des symboles extérieurs d'idées particulières.
} 
mudança traumática, essa mudança se manifesta por meio de artefatos" (PROWN, 1993, p. 13, tradução nossa) ${ }^{43}$.

Ainda sobre o papel dos objetos, Julien e Rosselin afirmam que os objetos são mais que "[...] reveladores da sociedade; eles se tornam verdadeiros nós de contato entre as sociedades" (JULIEN; ROSSELIN, 2005, p. 21, tradução nossa) ${ }^{44}$, sendo considerados um meio mais eficaz da difusão de uma cultura que suas ideologias.

Ao estudar a etimologia do termo objeto, Stocking (1985) identifica sete aspectos, a saber: três relacionados à sua materialidade; um com o tempo ou com a história; um referente, especificamente, à instituição museológica ${ }^{45}$; um aspecto referente às questões de valor monetário; e por último, mas não menos importante, Stocking identifica o aspecto estético do objeto.

Segundo os parâmetros da teoria da Cultura Material, o objeto tem três características principais: sua existência funcionalista, seu caráter semiótico e sua historicidade. A identificação dessas características principais possibilitou à disciplina a configurar suas três dimensões: uma espacial (que diz respeito às transformações naturais e seus resultados visíveis), uma cronológica (processos evolutivos) e uma social (diferenças no interior de uma comunidade). (BITTENCOURT, 1989; GRANATO et. al., 2007; MAROEVIC, 2006)

Apesar de estar fortemente conectada à questão da materialidade - objetos físicos - os pesquisadores em Cultura Material já identificaram que seu foco de estudo perpassa os objetos físicos e móveis, abrangendo, também, o homem, sendo seu próprio corpo um objeto, e todas as suas produções, materiais e imateriais, como as técnicas e os modos de fazer.

Pesez (2005), tomando emprestadas as teorias dos historiadores Aleksander Gleysztor e Henri Dunajewski, classifica a Cultura Material em quatro elementos, a saber: os meios de trabalho (homens, ferramentas); o objeto de trabalho (riquezas materiais, matérias-primas); a experiência do homem no processo de produção (técnicas); e a utilização dos produtos (consumo).

\footnotetext{
$43[\ldots]$ when a society undergoes a traumatic change, that change should manifest itself artifactually.

44 [...] plus que des révélateurs de societé: ils deviennent des noeuds de contact entre sociétés.

45 Stocking identifica como dimensão do objeto o processo de musealização, ou, como já visto anteriormente, a retirada do objeto do meio econômico para reapropriação pelo museu em outro contexto.
} 
Moles (1972) afirma que o objeto é vetor de comunicação, isto é, a concretização de um grande número de ações do homem na sociedade (MOLES, 1972), e ainda que os objetos se inscrevem "[...] no plano das mensagens que o meio social envia ao indivíduo ou, reciprocamente, que o Homo faber subministra à sociedade global" (MOLES, 1972, p. 11). Nessa perspectiva, os objetos materiais e imateriais devem ser entendidos como sistema de comunicação, isto é, sistema simbólico através do qual os indivíduos emitem todo tipo de informações, como, por exemplo, nível tecnológico e posição social.

[...] os objetos não apenas demarcam ou expressam tais posições e identidades, mas que na verdade, enquanto parte de um sistema de símbolos que é condição da vida social, organizam ou constituem o modo pelo qual os indivíduos e os grupos sociais experimentam subjetivamente suas identidades e status. (...) Importante assinalar que, a partir dessa perspectiva, os objetos materiais, como aqueles classificados como 'tecnologia' ou como 'arte', serão pensados não mais enquanto parte de uma totalidade social e cultural que se confunde com os limites de uma determinada sociedade ou cultura empiricamente considerada, mas sim enquanto parte de sistemas simbólicos ou categorias culturais cujo alcance ultrapassa esses limites empíricos e cuja função, mais do que 'representar', é a de organizar e constituir a vida social (GONÇALVES, 2007, p. 21)

Em 1986, Igor Kopytoff delineou a expressão biografia dos objetos buscando fornecer um quadro metodológico e analítico para a pesquisa em Cultura Material. Essa expressão, segundo o próprio autor, busca demonstrar que, da mesma maneira como é possível delinear a biografia das pessoas, incluindo todo o seu percurso de vida, o mesmo pode-se aplicar aos objetos:

Ao fazer a biografia de uma coisa, far-se-iam perguntas similares às que se fazem às pessoas: Quais são, sociologicamente, as possibilidades biográficas inerentes a esse 'status', e à época e à cultura, e como se concretizam essas possibilidades? De onde vem a coisa, e quem as fabricou? Qual foi sua carreira até aqui, e qual é a carreira que as pessoas consideram ideal para esse tipo de coisa? Quais são as 'idades' ou as fases da 'vida' reconhecidas de uma coisa, e quais são os mercados culturais para elas? Como mudam os usos da coisa conforme ela fica mais velha, e o que the acontece quando a sua utilidade chega ao fim? (KOPYTOFF, 2008, p. 92)

Para Kopytoff, o que se busca por meio dessa pesquisa na "vida" do objeto é verificar a história de suas várias singularizações, incluindo classificações e reclassificações, ou seja, os diversos valores atribuídos ao objeto, identificando, 
assim, o sistema social e as formas coletivas de conhecimento nos quais esse sistema se baseia.

Por outro lado, e complementando Kopytoff, Appadurai (2008) chama atenção para a distinção entre a biografia e a História Social das coisas, baseada na questão da escala social e da temporalidade.

Segundo o autor, quando pensamos em biografia dos objetos, estamos pensando os diversos contextos pelos quais passa uma coisa específica, acumulando uma história e valores particulares. Quando se estuda a trajetória de uma classe ou categoria de objetos, considerando as alterações e dinâmicas que transcendem a biografia de uma única coisa, definimos a História Social daquele grupo de objetos.

Assim, uma relíquia particular pode ter uma biografia específica, mas a totalidade dos tipos de relíquia - e, ainda, a própria classe de coisas chamadas 'relíquia' - tem um fluxo e refluxo histórico mais amplo, no decurso do qual seu significado pode se alterar expressivamente. (APPADURAI, 2008, p. 51-52)

No entanto, mesmo com essa diferença, no centro de ambos os conceitos estão as mensagens transmitidas, ou a ligação entre pessoas e coisas, e como significados e valores são acumulados e transformados.

Segundo Moles, com a aplicação da teoria da informação às ciências humanas, foi possível distinguir nessas mensagens dois aspectos diferentes: a mensagem semântica e a mensagem estética ${ }^{46}$. A interpretação dessas informações foi foco de estudo de profissionais das áreas de aplicação da Cultura Material, em especial da Antropologia, Arqueologia, Etnografia e História, tendo como resultado os chamados Estudos de Cultura Material ou Métodos de Análise de Objetos.

Os Estudos de Cultura Material ou Métodos de Análise de Objetos são metodologias criadas por profissionais de diversas áreas do conhecimento, incluindo Arqueologia e História da Arte, que buscam estudar o ciclo completo dos objetos ou grupos de objetos tendo por objetivo identificar toda a trajetória, da idealização até seu consumo ou uso e descarte ${ }^{47}$, incluindo os valores a eles atribuídos. Segundo

\footnotetext{
${ }^{46}$ No texto, Moles também chama, respectivamente, esses dois aspectos de mensagens denotativas e conotativas, ou ainda, significação e evocação.

${ }^{47}$ Nesse caso, inclui na categoria descarte, a alienação do meio econômico via patrimonialização e musealização.
} 
Gonçalves os objetos materiais circulam permanentemente pela vida social, e esses estudos acompanham esses diversos contextos: "[...] sejam trocas mercantis, sejam trocas cerimoniais, sejam aqueles espaços institucionais e discursivos tais como coleções, os museus e os chamados patrimônios culturais". (GONÇALVES, 2007, p. 15).

Ou seja, dizer que uma faca serve para cortar pode soar óbvio e redundante. (GONÇALVES, 2007) No entanto, se pararmos para analisar a trajetória social, incluindo suas funções e atribuição de valores, os objetos passam a ser vistos como provas de um determinado contexto. Percebe-se, então, que a análise de objetos perpassa suas características físicas.

$\mathrm{Na}$ etapa analítica, o paradigma histórico-cultural explorou intensamente técnicas para identificar, classificar e interpretar a cultura material, de tal forma que suas rotinas estabelecidas em laboratório acabaram por constituir o núcleo da prática arqueológica: desde a identificação da matéria-prima, sua origem e propriedades; do modo como são produzidos os artefatos; da sua função e dos usos a que eles foram submetidos, à análise dos seus atributos físicos, design e estilo, sua ordenação em tipologias, datações e, eventualmente, dependendo das motivações e inclinações do pesquisador, seriações. Os resultados desses procedimentos técnicos e metodológicos são, em geral, direcionados para a construção de categorias espaço-temporais, como fases e tradições, e para a atribuição dos achados a grupos específicos. Em alguns casos, são inseridos em argumentos e problemas mais amplos, visando alimentar, com os novos dados obtidos, as 'reconstruções' do passado. (LIMA,T., 2011, p. 14)

Rede (2003) identifica os Estudos de Cultura Material como as formas mais efetivas da análise histórica, uma vez que visam reconstituição de um tempo ou contexto pela análise dos vestígios materiais, dos sinais de manipulação pelo homem ou pela comparação etnográfica. Vale ressaltar, também, que o método para reconstrução da Cultura Material inclui a combinação de documentos escritos ou registrados com a evidência física (GRASSBY, 2005).

Apesar de originários do campo da Cultura Material, as metodologias para análise de objetos compõem, atualmente, corpo teórico e prático mais amplo, de natureza multidisciplinar, recebendo o status de disciplina independente, voltada para o estudo dos aspectos da relação entre o homem, seu meio social e sua produção material. Essas reflexões tem sido conduzidas por profissionais de diversas áreas do conhecimento, incluindo arqueólogos, estudiosos da História da 
Tecnologia, da Arte, da Arquitetura e do Design, bem como com semiólogos, sociólogos, antropólogos, historiadores sociais, museólogos, entre outras. "Se, por um lado, Arqueologia é estudo da cultura material, por outro, os estudos de cultura material transcendem a prática arqueológica." (LIMA, T., 2011, p. 12).

No que tange aos estudos desenvolvidos por profissionais de museu no campo da Cultura Material, é possível verificar seu foco no que concerne ao estudo da trajetória do objeto quando de sua musealização. Como visto anteriormente, a musealização é o processo de seleção e retirada de um determinado objeto de seu meio econômico-funcional para revaloração e inclusão em coleções museológicas: ao dar entrada em um museu, o objeto perde sua função prática e passa a ser documento, a ele sendo atribuído valor histórico e estético e tranformando-se em base de informações.

No contexto da musealização e da atribuição de valores mesmo após sua alienação do meio econômico, Bruno afirma que

[...] é porque as coisas não têm paz que a partir dos estudos desse universo de produção material é possível transgredir o seu contexto de visibilidade e penetrar nos cenários invisíveis, sensoriais e valorativos que extrapolam as barreiras impostas por análises pontuais ligadas, por exemplo, à medição dos objetos e à identificação da função dos artefatos, ou direcionadas para a organização de tipologias, ou ainda, esmagadas pela ênfase na proposição de hierarquias entre os conjuntos artefatuais. (BRUNO, 2009, p. 15)

Entretanto, Rede afirma que a noção de trajetória não se deve limitar à vida do objeto enquanto tal devendo ser estendida até o momento em que o objeto é musealizado (ALBERTI, 2005; REDE, 1996). Para Alberti, "[...] a biografia de um objeto não se estagna uma vez que ele entra no museu. Não obstante, a incorporação na coleção foi talvez o evento mais significante na vida do objeto museológico". (ALBERTI, 2005, p. 565) ${ }^{48}$.

Para o autor, pode-se identificar três fases pela qual o objeto passa: a primeira é seu contexto mecânico, da manufatura à musealização, incluindo suas mudanças de status; a segunda é a passagem pelos processos museológicos de classificação, pesquisa e comunicação; e a terceira fase é quando entra em contato

\footnotetext{
${ }^{48}$ Clearly the biography of an object did not stagnate once it arrived at the museum. Nevertheless, its incorporation into the collection was perhaps the most significant event in the life of a museum object.
} 
com o visitante (comunicação) ou pesquisador (disseminação da informação), possibilitando, assim, a interação e troca com o usuário. (ALBERTI, 2005) ${ }^{49} 50$. É na segunda fase, indicada por Alberti, que se desenvolvem os estudos dos profissionais que aplicam a teoria da Cultura Material e os Estudos de Cultura Material em ambiente museológico.

A questão da vida pós-musealização do objeto e a continuidade de sua vida foi tema de reflexão por Helena Dodd Ferrez, documentalista, que afirma que o objeto, após dar entrada no ambiente museológico, continua a ganhar informação: "um objeto, ao entrar para o contexto museológico, continua a ter vida e, por conseguinte, a ter uma história a ser documentada. Nos museus ele também ganha informação através, sobretudo, de pesquisas e da sua reutilização (ex.: exposições)" (FERREZ, 1994, p. 67)

Essa aplicação vai ao encontro com o que Mensch denomina de "[...] lógica aberta, abordando o objeto como 'fonte ilimitada de informações' e não se deixando limitar por metodologia desenvolvidas por disciplinas científicas e direcionadas a aspectos previamente determinados" (LOUREIRO, 2012, p. 102, grifo nosso).

Segundo Maroevic (2006), todo objeto, independente de tipologias ou origem, são portadores de informação e mensagens do passado: "[...] um objeto carrega seus valores simbólicos e semânticos em sua estrutura". (MAROEVIC, 2006, p. $24)^{51}$. A aplicação dos Estudos de Cultura Material permite, então, a interpretação das diversas camadas informacionais do objeto, bem como de suas múltiplas identidades, da conceitual à atual, passando pela factual, funcional e estrutural (BITTENCOURT, 2012; MAROEVIC, 2006).

Ao longo do sua história, o Museu se configurou como instituição de reconstrução do passado a partir da acumulação de objetos e de narrativas construídas pelos vestígios ali preservados. A função do museólogo, ou profissional

\footnotetext{
${ }^{49}$ Cabe ressaltar que todos os eventos ou as atribuições de valores aos objetos que acontecem após sua musealização, como por exemplo participsção em exposições ou fotograifas em publicações, devem constar no dossiê do objeto. Ou seja, o acompnhamento à trajetória do objeto não termina na segunda fase indicada por Albert.

50 Peter van Mensch (2005, apud MAIRESSE, 2011, p .254) identifica como as fases do objeto: 1 contexto primário: no qual o objeto é idealizado, criado e utilizado; 2- contexto secundário: o contexto do descarta, do detrido, do resto; 3- contexto museal ou patrimonial: o da musealização e da preservação.

${ }^{51}$ An object carries its symbolic and other semantic values within its structure.
} 
que trabalha com essas coleções, é construir narrativas a partir da conexão entre os vestígios, formando seqüências significativas, elaborando sentidos e obedecendo a modelos e padrões pré-estabelecidos pela Museologia. (BECKOW, 1999; LOUREIRO; LOUREIRO; SILVA, 2008).

Como visto anteriormente, diversos pesquisadores vêm atuando nessas instituições tendo como foco essa aplicação da teoria da Cultura Material no campo museológico. Entre estes profissionais destaca-se Susan Pearce.

Susan Pearce (1942-) é uma historiadora e arqueóloga inglesa, formada na Oxford University. Durante toda a sua vida profissional atuou na equipe curatorial de diversas instituições museológicas, como o National Museum on Merseyside e o Exeter City Museum. Terminou seu doutorado na University of Leicester em 1989, onde atua, atualmente, como professora emérita no curso de museus. Foi, também, presidente da Museum Association entre 1992 e 1994.

As pesquisas de Pearce têm foco na Cultura Material, em particular na relação entre os objetos e a prática do colecionismo. Seus estudos deram origem a importantes publicações para a prática museológica, incluindo Museum Studies in Material Culture (1989) ${ }^{52}$, Museum, Objects and Collections (1992) ${ }^{53}$ e Interpreting Objects and Collections (1994) ${ }^{54}$, todos usados no curso de museus da University of Leicester e que reúnem as principais teorias de Pearce, apresentando novas abordagens para o estudo de objetos e utilizando como base a perspectiva arqueológica, linguistica e semiológica.

Susan Pearce aplica a teoria linguística da langue e da parole de Ferdinand de Sausurre (1857-1913) aos objetos e, posteriormente, às coleções museológicas.

\footnotetext{
52 Editado por Susan Pearce, é um livro composto por 14 artigos de professores especializados em disciplinas que envolvem o estudo de objetos, como Arqueologia, História Social, Artes Aplicadas e Antropologia. Esses artigos tem como principal objetivo discutir a interpretação da cultura material e é o primeiro livro de Susan que busca identificar e discutir por um viés teórico essa interpretação no contexto das coleções museológicas.

53 Livro escrito por Perce focado no papel central do objeto em todas as atividades em uma instituição museológica e a importância da coleção para o curador, entendido como o profissional que atua na interpretação dos objetos e seu posterior uso em processos comunicacionais.

54 Conjunto de artigos selecionados por Susan Pearce, incluindo oito assinados pela própria organizadora. Os trinta e oito artigos coletados foram divididos em duas partes (Interpretando Objetos e Interpretando Coleções) e têm em comum a crença de que museus existem para manter objetos e espécimes que foram preservados do passado, a partir da prática do colecionismo, e que essas instituições constituem um fenômeno social específico com o papel importante no sistema dos objetos. Entre os autores selecionados para compor esse volume estão Arjun Appadurai, James Deetz, Krzysztof Pomian, entre outros importantes teóricos que pesquisam a temática.
} 
Para a autora, langue seria toda a sorte de objetos e parole esses objetos em relação e em uso. Já em contexto museológico, langue seriam os objetos que foram coletados e que formam as coleções, e parole, por sua vez, seria esses objetos em relação e a construção de narrativas expositivas, conforme é possível verificar na imagem abaixo.

Figura 4 - Teoria Semiológica de Susan Pearce

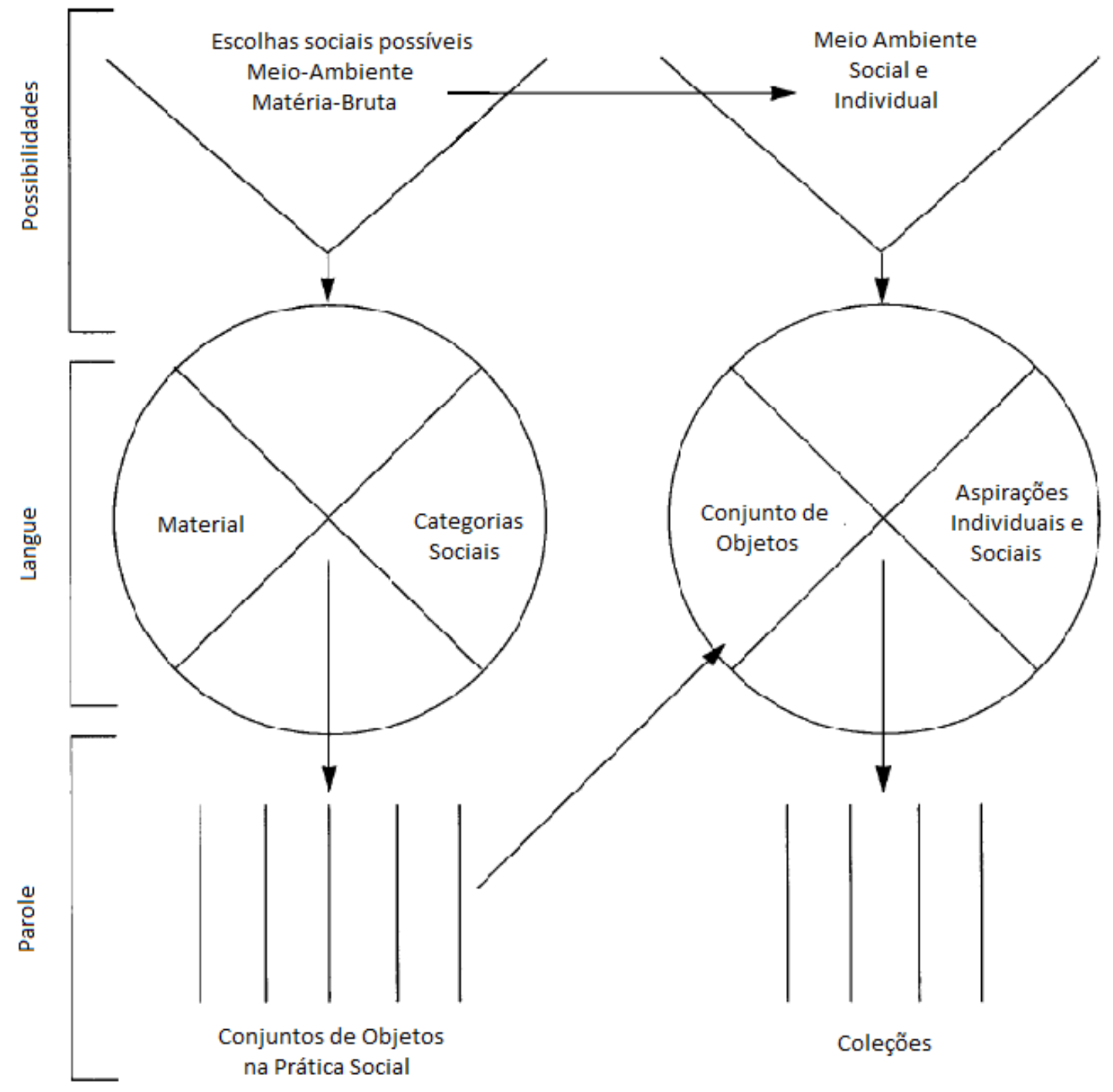

Fonte: traduzido de Pearce, 1989; 1992; 1994.

Além de aplicar a teoria linguística às coleções, Pearce também identifica seis modelos de estudo de objetos, ou Estudos de Cultura Material, desenvolvidos por 
atores de diversas áreas do conhecimento, para aplicação em coleções museológicas. O quadro a seguir apresenta quais são esse modelos identificados pela autora ${ }^{55}$, seus criadores e em que publicação de Pearce eles aparecem como indicados para uso em contexto museológico:

\section{Quadro 6 - Modelos de Estudo de Objetos propostos por Susan Pearce para aplicação em contexto museológico}

\begin{tabular}{|l|l|l|}
\hline \multicolumn{1}{|c|}{ MODELO } & \multicolumn{1}{|c|}{$\begin{array}{c}\text { AutORES DOS } \\
\text { MODELOS }\end{array}$} & \multicolumn{1}{|c|}{$\begin{array}{c}\text { PUBLICAÇÃO DE SUSAN QUE } \\
\text { REFERENCIA OS MODELOS }\end{array}$} \\
\hline Not looking at keetles & R. Batchelor & $\begin{array}{l}\text { Museum, Objects and Collections } \\
\text { (1992); Interpreting Objects and } \\
\text { Collections (1994) }\end{array}$ \\
\hline $\begin{array}{l}\text { Towards a material } \\
\text { history methodology }\end{array}$ & R. Elliot & $\begin{array}{l}\text { Museum, Objects and Collections } \\
(1992) ; \text { Interpreting Objects and } \\
\text { Collections (1994) }\end{array}$ \\
\hline $\begin{array}{l}\text { Artifact study: a } \\
\text { proposed model }\end{array}$ & E. M. Fleming & $\begin{array}{l}\text { Museum, Objects and Collections } \\
(1992)\end{array}$ \\
\hline $\begin{array}{l}\text { The connoisseurship of } \\
\text { artifacts }\end{array}$ & C. Montgomery & $\begin{array}{l}\text { Museum, Objects and Collections } \\
(1992)\end{array}$ \\
\hline $\begin{array}{l}\text { Thinking about things } \\
\text { The }\end{array}$ & S. Pearce & $\begin{array}{l}\text { Museum, Objects and Collections } \\
(1992) ; \text { Interpreting Objects and } \\
\text { Collections (1994) }\end{array}$ \\
\hline $\begin{array}{l}\text { Mind in matters: an } \\
\text { introduction to material } \\
\text { culture theory and } \\
\text { method }\end{array}$ & J. Prown & $\begin{array}{l}\text { Museum, Objects and Collections } \\
(1992) ; \text { Interpreting Objects and } \\
\text { Collections (1994) }\end{array}$ \\
\hline
\end{tabular}

Fonte: adaptado de PEARCE, 1992; 1994.

Cada um desses modelos propostos por Susan foi desenvolvido no âmbito do estudo de objetos de uma determinada área do conhecimento: Arqueologia, História, Artes Plásticas, etc.

No que diz respeito à aplicação em contexto museológico, os Estudos de Cultura Material vêm ajudar nos processos da Gestão da Coleção, incluindo a Documentação em Museus, em especial na análise da informação para posterior representação e recuperação.

55 Esse modelos são apresentados em artigos publicados pro seus autores. No quadro se encontram os títulos desses artigos. Preferiu-se manter o nome em inglês, uma vez que esses artigos não foram oficialmente traduzidos para a língua portuguesa. 
O propósito da pesquisa "Tratamento Informacional da Coleção Telegráfica do Museu Correios: análise sob a perspectiva científica, tecnológica e de cultura material" foi analisar esses modelos indicados por Susan Pearce em sua bibliografia, visando adequação dos Estudos de Cultura Material à análise da informação de uma coleção específica de ciência e tecnologia musealizada - a coleção telegráfica do Museu Correios.

\subsection{Museu de Ciência e Tecnologia: o Museu Correios}

O Conselho Internacional de Museus (ICOM), junto ao Comitê Internacional para a Museologia (ICOFOM), têm desenvolvido amplo trabalho delimitando epistemologicamente a área enquanto ciência. Um desses trabalhos é o estudo da instituição museológica e as diversas tipologias existentes, tendo por base o acervo que as compõem, as Áreas de Conhecimento que respondem pelas coleções e as ações empreendidas junto ao público.

Dentre essas tipologias, se encontram os Museus de Ciência e Tecnologia (C\&T). Para melhor compreensão desta tipologia de museu, buscaremos as definições de 'Ciência' e 'Tecnologia' expostas por Marcos Granato, um dos principais estudiosos no tema em âmbito nacional.

Para Granato (2009, p.78-79), Ciência pode ser definida como o "[...] conjunto de conhecimentos e de investigações com um suficiente grau de generalidade para resultar em convenções concordantes e relações objetivas baseadas em fatos comprováveis". Por outro lado, o autor define tecnologia como "[...] o estudo dos processos técnicos, naquilo que eles têm de geral e nas suas relações com o desenvolvimento da civilização".

Dentro desse ambiente conceitual, os Museus de C\&T devem ser entendidos como instituições que têm a missão de salvaguardar a História da Ciência e da Técnica, da evolução geral às últimas inovações, sem desligá-las de seu contexto histórico e social (FERNANDEZ, 2010). Dessa forma esses museus ${ }^{56}$

\footnotetext{
56 [...] los museos de ciencia y de la técnica están obligados a proporcionar al visitante los médios adecuados para comprender la evolución y desarrollo de la civilización industrial, y a descubrir en ella los valores socioculturales, entre otros tanta veces debatida adecuación entre el nível de vida del hombre y el avance técnico-industrial.
} 
[...] são necessários para proporcionar ao visitante os meios adequados para compreender a evolução e desenvolvimento da civilização industrial, entre tantas outras vezes debatidos, combinando o padrão de vida do homem e o progresso técnicoindustrial. (FERNANDEZ, 2010, p. 132, tradução nossa)

Então, os museus de C\&T são instituições que buscam preservar (incluindo pesquisa, conservação e comunicação) o chamado Patrimônio de C\&T, tendo por objetivo principal exercer papel fundamental na produção de conhecimento acerca da história da ciência e da técnica.

O Patrimônio de C\&T deve ser entendido como

[...] todos aqueles objetos (inclusive documentos em suporte papel), coleções arqueológicas, etnográficas e espécies de coleção biológicas que são testemunhos dos processos científicos e do desenvolvimento tecnológico e que tenham passado pelo que denominamos momentu museologicum, ou seja, de sua incorporação à coleção de um museu. (GRANATO, 2010, p. 239, grifo nosso)

$\mathrm{Na}$ categoria de objetos que compõem o Patrimônio de C\&T, é possível identificar com maior facilidade os denominados instrumentos científicos, uma vez que estão intrinsecamente ligados à tecnologia aplicada e à ciência como um todo, incluindo os trabalhos laboratoriais. No entanto, conforme aponta Granato (2009), o termo instrumento científico é aplicado somente em objetos de um período histórico determinado (séc. XIX e início do séc. XX), sendo, portanto, mais indicado o uso do termo aparato científico ou objeto de ciência e tecnologia ${ }^{57}$.

Formadores de coleções, esses objetos são considerados os registros materiais da história científica e tecnológica, além de desempenharem o papel de documento - fontes de informação e produção de conhecimento acerca da temática que representam.

As coleções de objetos de Ciência e Tecnologia podem ser divididas, conforme Rolland-Villemont (1997) em quatro categorias, a saber:

- coleções científicas: herança das coleções dos gabinetes de curiosidades do século XVIII;

${ }^{57}$ Foi mantida a terminologia utilizada pelos profissionais que já se debruçaram sobre as temáticas do patrimônio de ciência e tecnologia: Objeto de Ciência e Tecnologia. No entanto, é possível verificarmos, além de instrumento científico, a uso do termo artefato para identificar essa tipologia de objeto. 
- coleções técnicas: que são as coleções de modelos utilizados para ensino ou para o conhecimento de uma técnica;

- coleções industriais: que são ligadas a uma área da indústria e representam toda a cadeia de operações que envolvem a extração e a transformação dos materiais até o produto final;

- coleções de transportes e de comunicações.

Dentro dessa última categoria de acervo podemos incluir os objeto que testemunharam o desenvolvimento da telegrafia no Brasil, e que tem no Museu Correios o único representante dessa faceta da evolução tecnológica nacional.

Até início do século $X X$ os serviços postal e telegráfico eram de responsabilidade de órgãos distintos: a Diretoria Geral de Correios (DGC) e a Repartição Geral dos Telégrafos (RGT), respectivamente. Assim, para poder entender a história do Museu Correios, faz-se necessário contar como as questões de memória e patrimônio eram tratadas por esses órgãos.

Abrir um Museu para contar a história do serviço postal é um projeto que remonta ao fim do século XIX. De acordo com Santiago (2012, p.14) foi na administração do Dr. Luiz Betim Paes Leme (1882-1891) que foi criada a Biblioteca Postal (1888) e o Museu Postal (1889). Vale ressaltar que no texto do documento que regulamenta o museu - Portaria ํํ 119 de 1889 - o diretor-geral já orienta as divisões e seções dos Correios a recolher e organizar carimbos, sinetes e outros objetos não mais utilizados para compor a coleção do Museu Postal (SANTIAGO, 2012, p.15).

O Museu Telegráfico foi criado pelo Barão de Capanema - responsável, também, pela implantação da telegrafia elétrica no país (1852). Ao contrário do Museu Postal, o Museu Telegráfico não possui documentação que prove seu funcionamento (SANTIAGO, 2012). As fotografias utilizadas na publicação "Memória Histórica da RGT", de 1907, documentam salas onde ficava o acervo exposto com etiquetas e, em alguns casos, legendas, conforme ilustrações a seguir. 
Figura 5 - Sala de Experiências do Museu Telegráfico

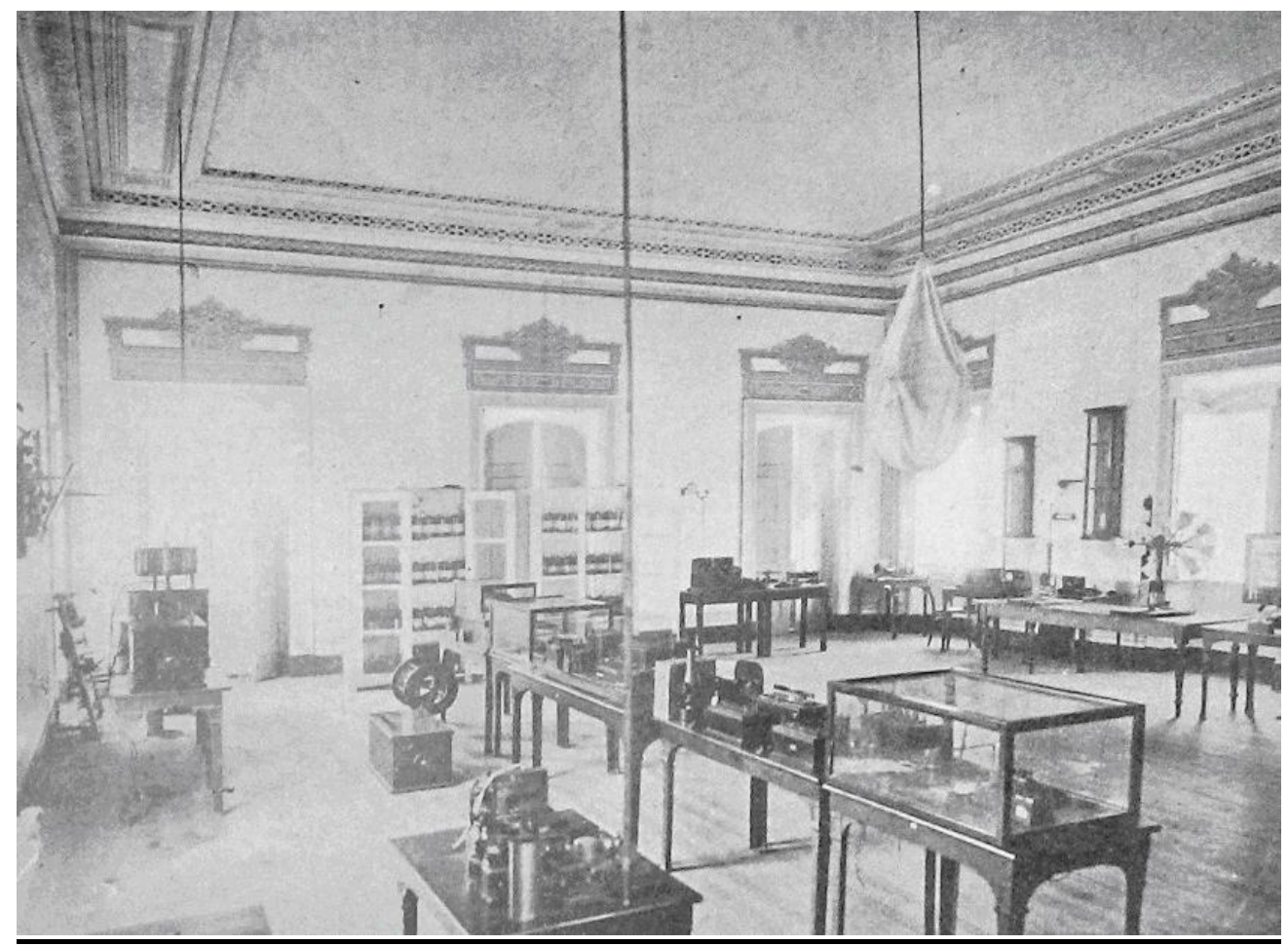

Fonte: RGT, 1907, n/p

Figura 6 - Museu - Sala dos Materiais e Ferramentas das Linhas

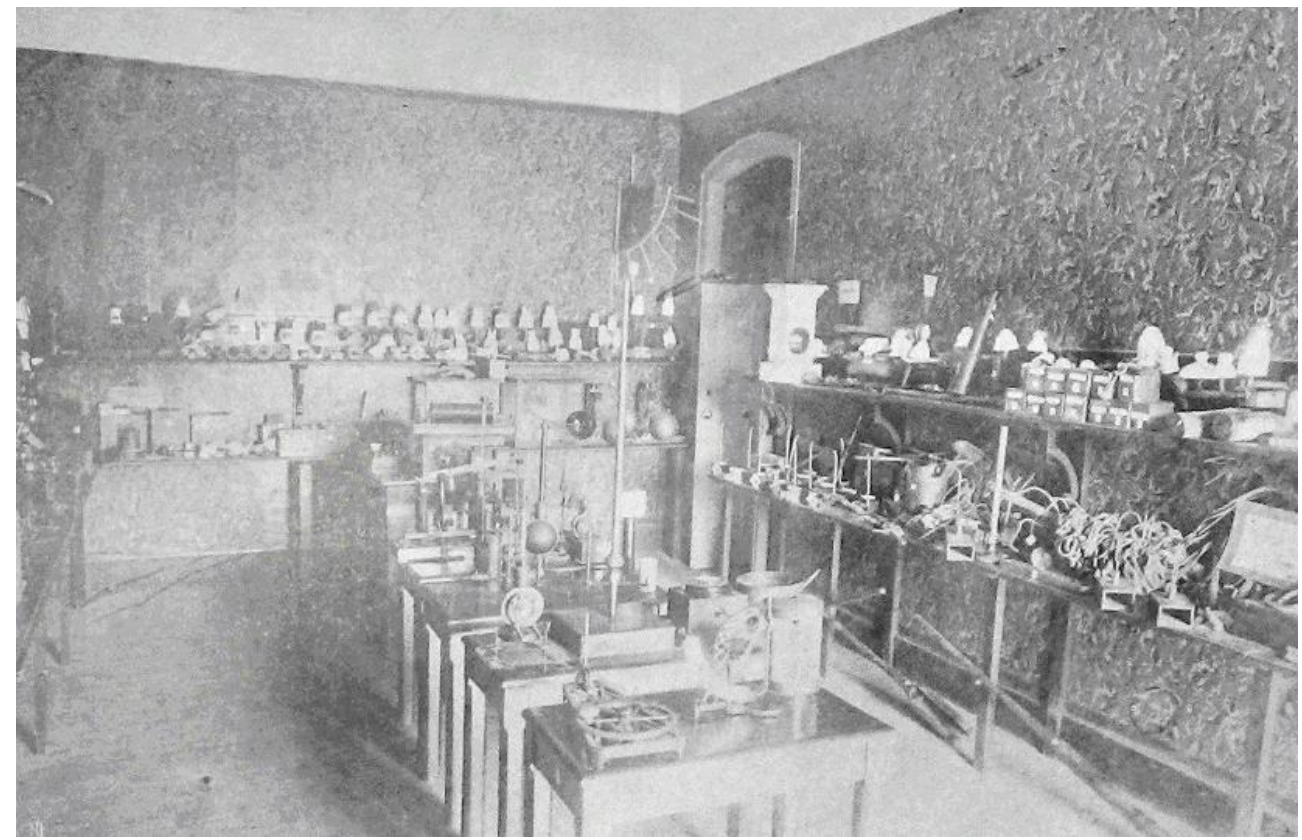

Fonte: RGT, 1907, n/p

A abertura do Museu Postal e do Museu Telegráfico em fins do século XIX é significativa uma vez que é somente no séc. XX que se consolidam os grandes 
Museus Históricos. Segundo Almeida (2001, p.135), é a partir das primeiras décadas dos anos 1900, que

[...] o próprio Estado exerce o papel de 'colecionador', criando museus e formando suas respectivas coleções em momentos principalmente nos momentos de enaltecimento ou engrandecimento das 'tradições', ações que se utilizam de estratégias de 'resgate' do passado como elemento legitimador e aglutinador da nação.

Percebe-se então o papel pioneiro que os órgãos responsáveis pela comunicações no Brasil exerceram no que diz respeito à consolidação de suas instituições de memória.

Na década de 1930, com a criação do Departamento de Correios e Telégrafos (DCT) que aglutinava a RGT e a DGC em um único órgão, foi criado o Museu Postal-Telegráfico (1931). Santiago chama a atenção, inclusive, para o caráter de pesquisa e educação com o qual a instituição havia sido pensada, citando seu decreto de criação que aponta sua função de, ao despertar o interesse geral pelos objetos ali guardados, atrair um maior número de visitantes e pesquisdores (SANTIAGO, 2012). Outra característica marcante desse período é a feição educativa do museu, que servia como escola de aperfeiçoamento para novos funcionários.

Com a mudança para Brasília, a extinção do DCT e criação da Empresa Brasileira de Correios e Telégrafos (ECT) foi criado um grupo para a estruturação de uma nova instituição museológica que preservasse a memória dos serviços prestados pelo novo órgão. Em 1980 a ECT abre as portas do seu, então denominado, Museu Postal e Telegráfico. O espaço contava a história da empresa e do serviço postal no Brasil, com ênfase nas coleções filatélicas, de Marcofilia (carimbos) e de objetos relacionados à história postal e telegráfica, como aparelhos de telégrafos, equipamentos de agências postais e remanescentes de tecnologias empregadas nos Correios, como o caso do serviço pneumático ${ }^{58}$.

O Museu Postal e Telegráfico funcionou até o ano de 2001. Durante a primeira década dos anos 2000, todo o acervo foi transferido para outro prédio e a ECT iniciou reformas no prédio que abrigava o Museu. Um grupo de estudos foi

58 O sistema pneumático foi implantado entre o prédio do Paço Imperial e o prédio do governo, atual Museu da República, no Rio de Janeiro. Consistia em tubulação subterrânea em que a carta era transportada por ar pressurizado dentro de uma cápsula metálica. 
criado, visando reestruturação da instituição e das exposições para reabertura ao público.

Com novo nome, novas instalações, e sob a responsabilidade do Departamento de Gestão Cultural (DEGEC), o Museu Correios (MC) ${ }^{59}$ foi reaberto em 25 de janeiro de $2012^{60}$. Seu acervo é composto por peças que referenciam a história postal, telegráfica e filatélica (incluindo Marcofilia) brasileira, bem como da Empresa.

Figura 7 - Interior de Agência no início do século XX e reprodução no Museu Correios

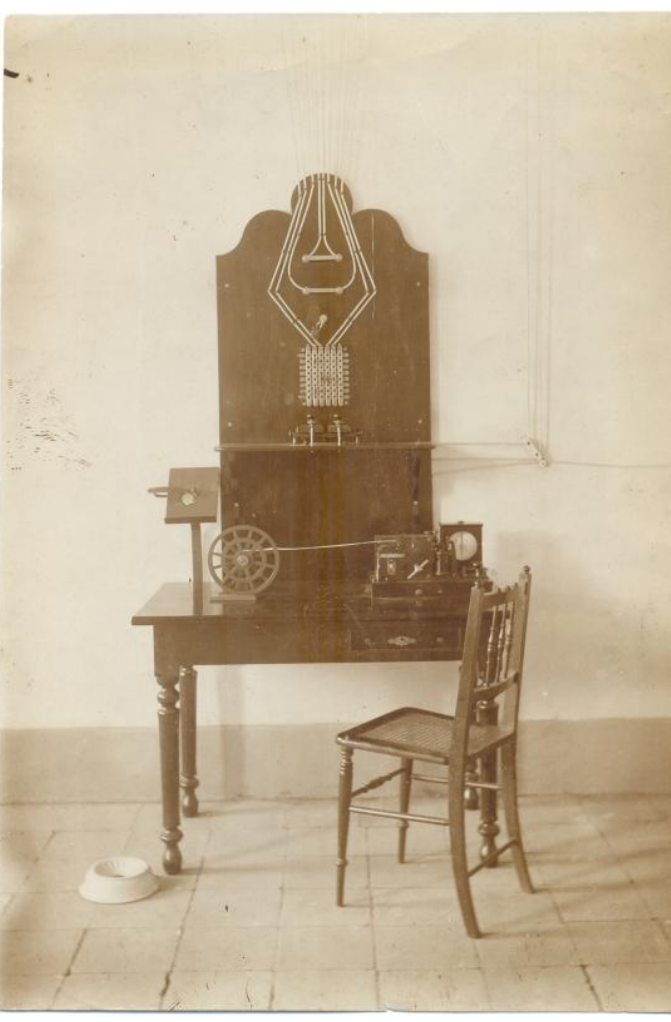

Foto: Autor desconhecido Acervo Museu Correios

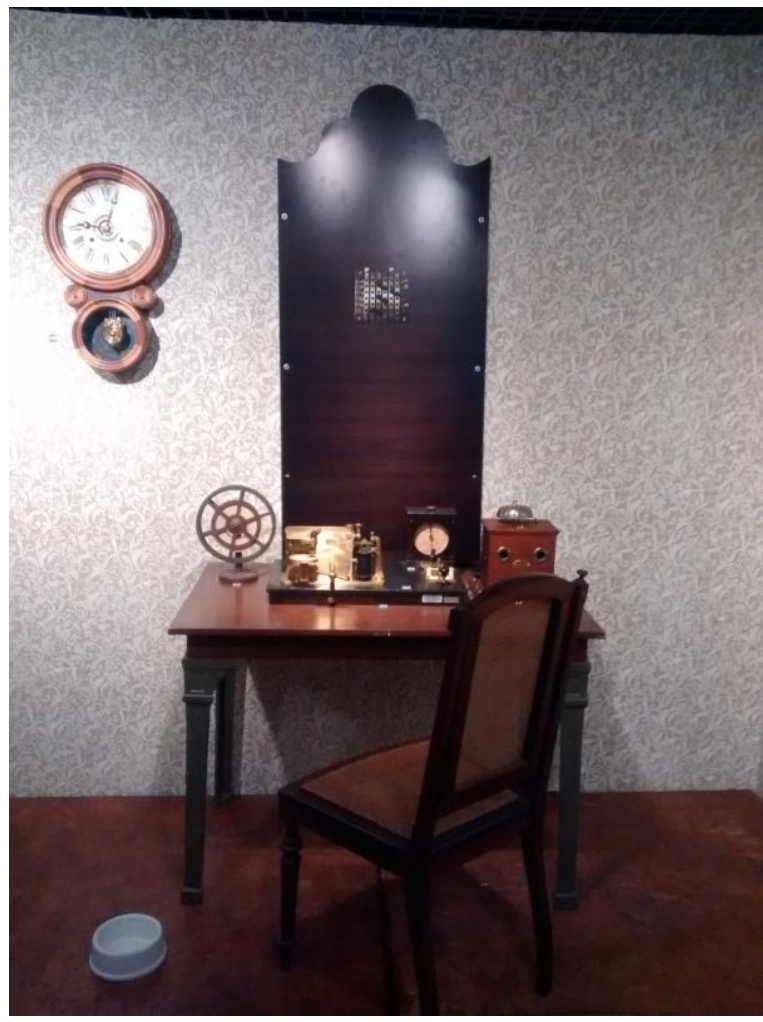

Foto: Bernardo Arribada

A coleção telegráfica do Museu Correios, foco desse estudo, se desenvolveu a partir do que Bergeron denomina Coleção Pedagógica, ou seja, uma conjunto de objetos “[...] cuja função primária é a de responder à necessidades pedagógica de ensino [...] e que adquiriu com o tempo uma função secundária que lhe confere o

59 Em 2014 a ECT inicia uma reestruturação, incluindo mudança da marca, organograma e nome: passa a se chamar Correios. O Museu Correios, antigamente Museu Nacional dos Correios, mudou o nome acompanhando esse novo contexto.

${ }^{60}$ Mais informações do Museu Correios na seção 3. Metodologia. 
estatuto de coleção museológica"61 (BERGERON, 2011, p.66, tradução nossa). Os objetos coletados e que dariam origem, futuramente, à coleção eram usados pela RGT no treinamento dos novos funcionários. Ou seja, os objetos foram recolhidos para o centro de treinamento, visando auxiliar no entendimento do mecanismo dos aparelhos e das ligações telegráficas e, posteriormente, transferidos para o museu.

A telegrafia surge no contexto do desenvolvimento de tecnologias que permitissem comunicação a distância ${ }^{62}$, tendo por inovação principal o rompimento, num primeiro momento da barreira temporal (instantaneidade), e posteriormente das barreiras geográficas. Pode-se identificar como inovação, também, a elaboração de sistemas que permitissem a codificação e decodificação de mensagens em sinais, como os códigos morse e baudot.

As primeiras tecnologias telegráficas empregadas no Brasil eram chamados de semafóricos ${ }^{63}$. No século XVIII os chamados telégrafos de bandeira foram instalados em pontos estratégicos de algumas cidades brasileiras. O posto mais conhecido foi o do Morro do Castelo, no Rio de Janeiro, que recebia informações da Fortaleza de Santa Cruz e do Morro da Babilônia, em Copacabana, sobre a chegada de navios. Esse sistema funcionou até o início do século $X X$, quando o morro em questão foi derrubado para a expansão da capital fluminense.

No século XIX, com as descobertas no campo da eletrodinâmica, do eletromagnetismo e de outros campos da física, os cientistas norte-americanos e europeus desenvolveram protótipos que buscavam a transmissão de informação codificada via corrente elétrica. Dentre eles, destaca-se o cientista Samuel Finley Breese Morse (1791-1872) que inventou, em 1838, um sistema cujo único fio transmitia mensagens com auxílio de um código - código morse - estruturado em impulsos elétricos curtos ou longos que representavam pontos ou traços, respectivamente.

\footnotetext{
61 [...] est une collection dont la fonction première est de répondre aux besoins pédagogiques de l'enseignement [...] et qui a acquis avec le temp une fonction seconde qui lui confère le statut de collection muséale.

62 O sufixo grego tele significa distância. Ex: telecomunicação = comunicação à distância.

63 Apesar de já haver comunicação à distância, como os sinos das igrejas coloniais, o marco da telegrafia no Brasil foi o sistema por fogo da Torre de Garcia D’Ávila, em Salvador, no século XVII e, posteriormente, no século XVIII, os telégrafos de bandeiras, como o do Morro do Castelo.
} 
Figura 8 - Estação de Telegrafia Ótica do Morro do Castelo - Rio de Janeiro

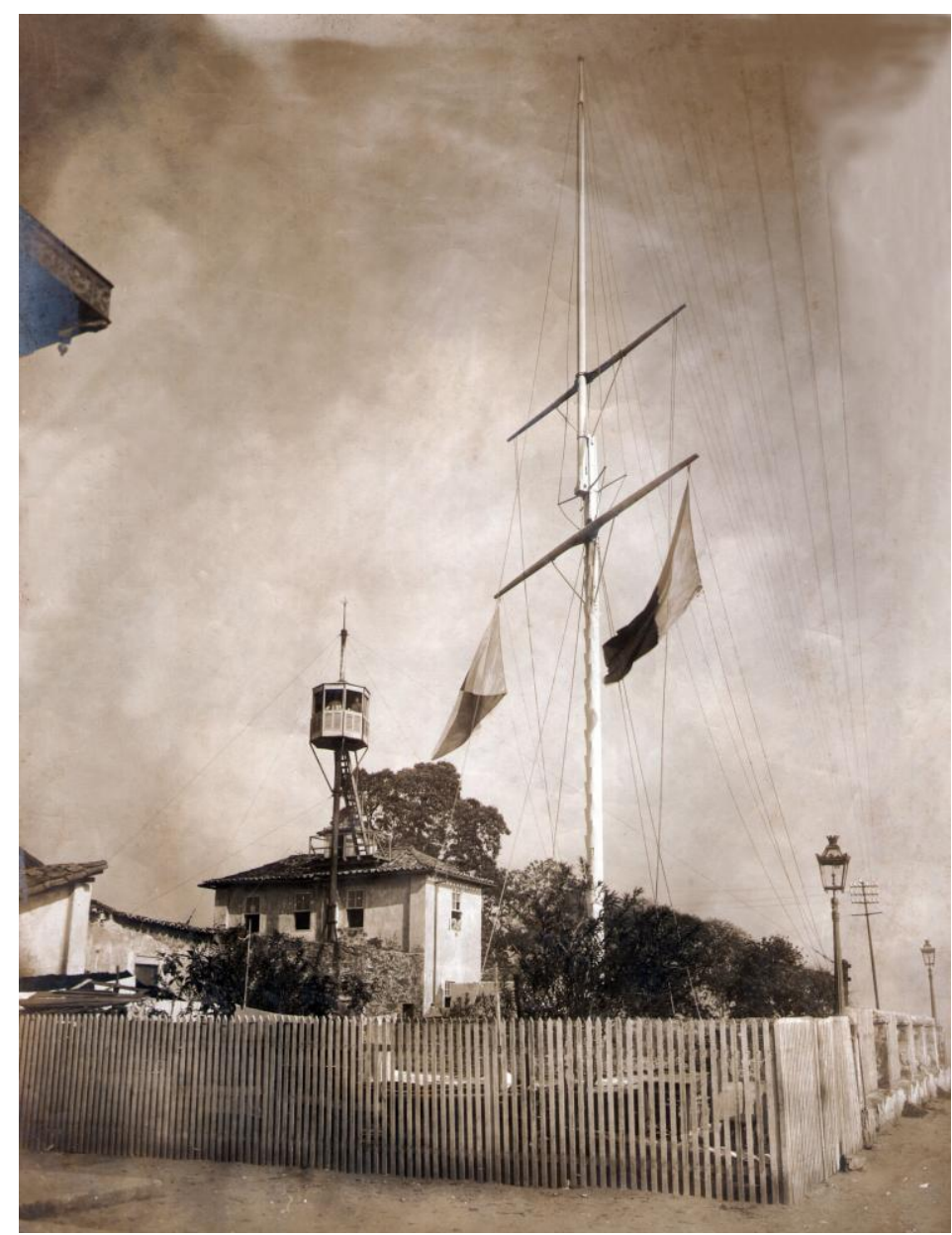

Acervo Museu Correios

O desenvolvimento da telegrafia no Brasil se deu, principalmente, por questões políticas ${ }^{64}$. Além da repressão ao tráfico negreiro, o telégrafo foi instalado no Brasil, na década de 1850, como auxílio ao controle e segurança do grande território que propiciava movimentos separatistas.

O conhecimento dos progressos que, no exterior, ia fazendo a aplicação da eletricidade à telegrafia despertou também o interesse para seu uso no Brasil. Em 1851, o governo brasileiro recebeu, por meio de um ofício do Ministro do Brasil em Washington, conselheiro Sergio Teixeira de Macedo, uma proposta do norte-americano J. L. Leonardt para estabelecer comunicação telegráfica entre diversas cidades do império brasileiro. No entanto, o empresário faleceu durante as negociações com o governo brasileiro em 1851. (SILVA e MOREIRA, 2007, p.49)

O então ministro da justiça Eusébio de Queiroz Coutinho Mattoso Câmara (1812-1868) procurou o Dr. Francisco Paula Candido (1805-1864), professor de

64 Contexto diferente do que havia acontecido em outras partes do mundo, onde o desenvolvimento da telegrafia se deu por motivos econômicos. 
física da Faculdade de Medicina, que se prontificou a fazer os primeiros testes, com a instalação de uma linha improvisada no quartel da polícia, na Rua dos Barbonos atual Rua Evaristo da Veiga - até o Morro do Castelo, onde se encontrava a estação do telégrafo semafórico.

A primeira experiência para instalação da telegrafia no Brasil falhou. $O$ material usado: fios de cobre, cobertos de seda embebidos de resina; isoladores de fundos de garrafa; e dois aparelhos Bréguet, pertencentes ao Gabinete de Eletricidade Prática da Escola Central cedidos pelo professor Guilherme Schüch de Capanema (1824-1909), lente de física da escola. (SILVA; MOREIRA, 2007)

Para provar que a falha não havia sido do equipamento, e sim da ligação, Capanema se propõe a refazer a experiência, porém agora com menor distância e aparatos, conseguindo transmitir sinais para a sala vizinha, com fiação passando pela janela.

Figura 9 - Aparelho Transmissor Bréguet

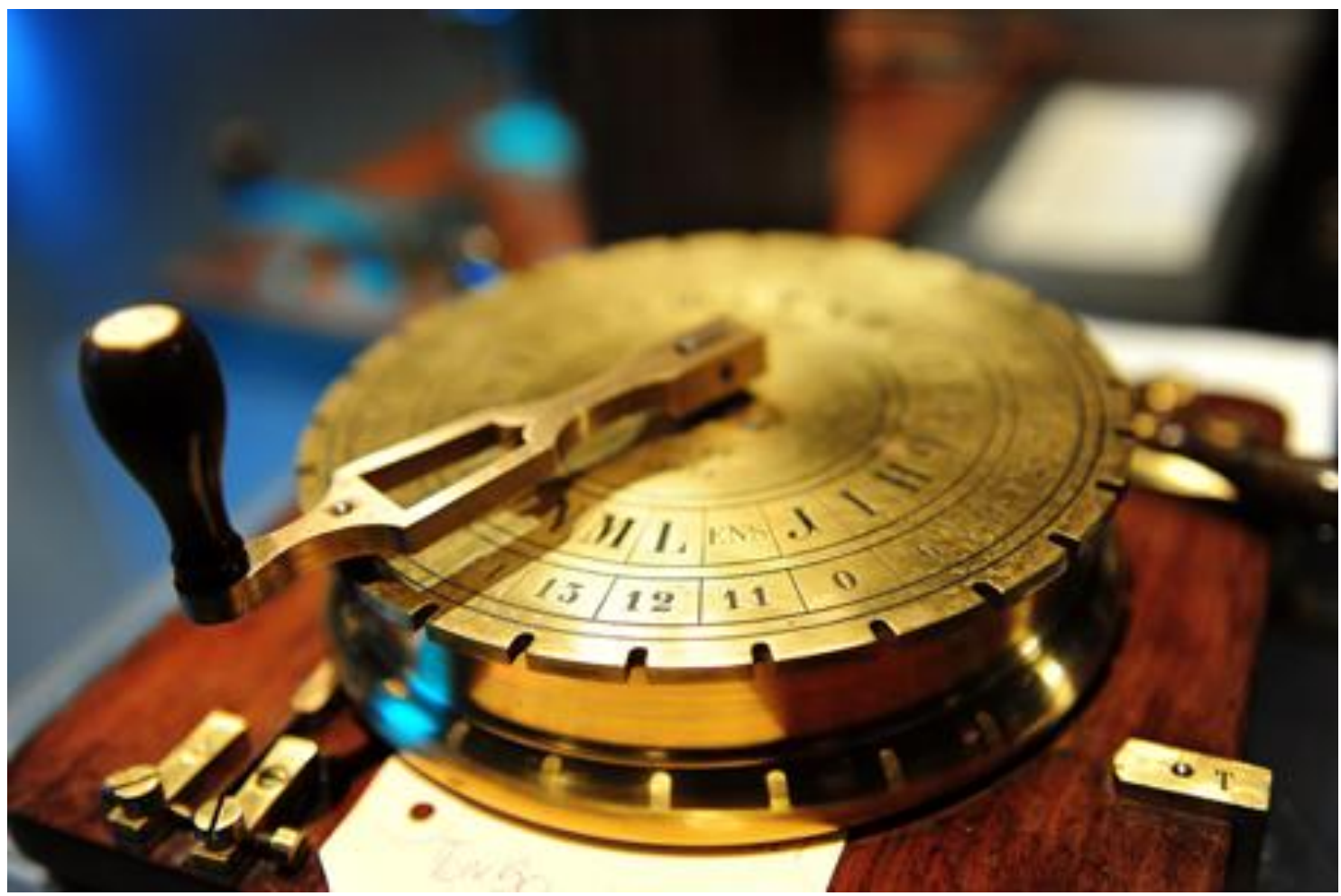

Foto: Jair Xavier - Acervo Museu Correios

Ao saber do sucesso dessa segunda experiência, o ministro Eusébio de Queiroz solicitou ao professor uma relação do material necessário para as primeiras instalações telegráficas - entre a Quinta Imperial e o Quartel do Campo de Santana, 
as Secretarias de Polícia, da Justiça e a estação do Morro do Castelo. O material incluía cabos e aparelhos telegráficos - sendo dessa vez os famosos aparelhos Morse. Nesse momento, fundava-se o Telégrafo Nacional. Guilherme Capanema foi nomeado, em 1851, aos 28 anos, encarregado dos telégrafos no Brasil.

Capanema buscou, num primeiro momento, ligar o Rio de Janeiro a Pernambuco, pela chamada Linha do Norte. No entanto, com a eclosão da Guerra do Paraguai, fez-se imperativo e emergencial a ligação com Rio Grande do Sul, que torna-se realidade em 1866. O conflito fez com que a telegrafia ganhasse novo status: torna-se estratégica e necessária para o desenvolvimento nacional.

Figura 10 - Aparelho Morse, com receptor e transmissor

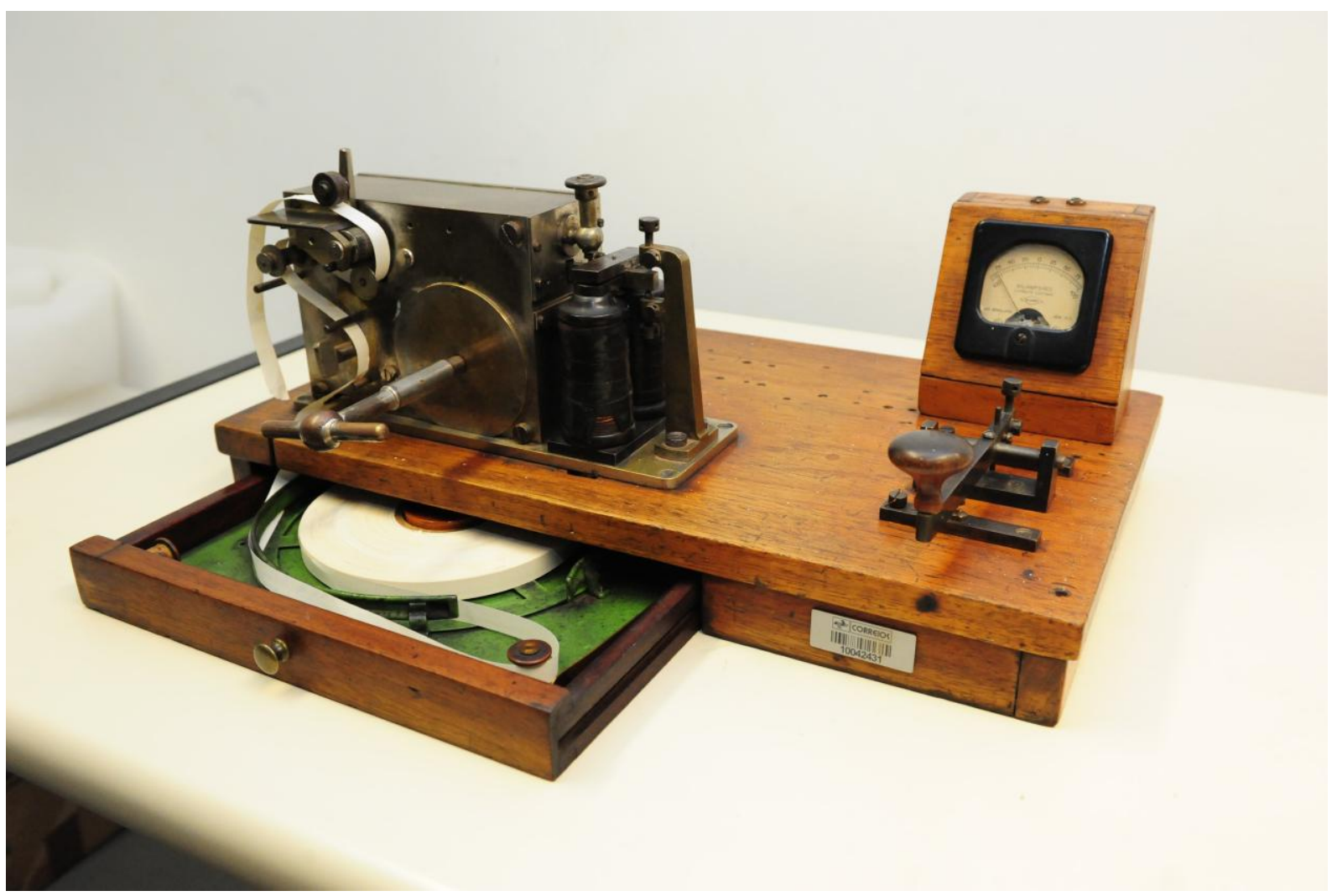

Foto: Jair Xavier - Acervo Museu Correios

No mesmo ano, os Estados Unidos da América se liga à Europa por cabos submarinos dando o pontapé inicial ao que viria a ser a primeira rede mundical de telecomunicação. O Brasil entraria nessa rede, com ligação direta entre Recife e Lisboa, em 1874, graças aos esforços do Barão de Mauá, que também era responsável pela linha costeira. 
Em 1896, todas as capitais brasileiras estavam interligadas pelo telégrafo. No entanto, o interior do território nacional, ou seja, as regiões Centro-Oeste e Noroeste do Brasil, não haviam sido conectadas à malha telegráfica. O responsável por contornar essa situação foi Cândido Mariano da Silva Rondon. O primeiro avanço empreendido se deu na década de 1890, com a ligação entre Mato Grosso e Goiás. Depois desse primeiro momento, o Marechal Rondon levou a telegrafia até Corumbá.

A partir de 1907, com a instituição das chamadas "Comissões Rondon", foi realizada a conexão entre Cuiabá a Santo Antônio do Madeira, atual Porto Velho. Todavia, quando Rondon chegou ao territorio onde seria fundada a futura capital do estado de Rondônia, já se encontrava em funcionamento a radiotelegrafia.

Figura 11 - Aparelho Baudot, com receptor e transmissor

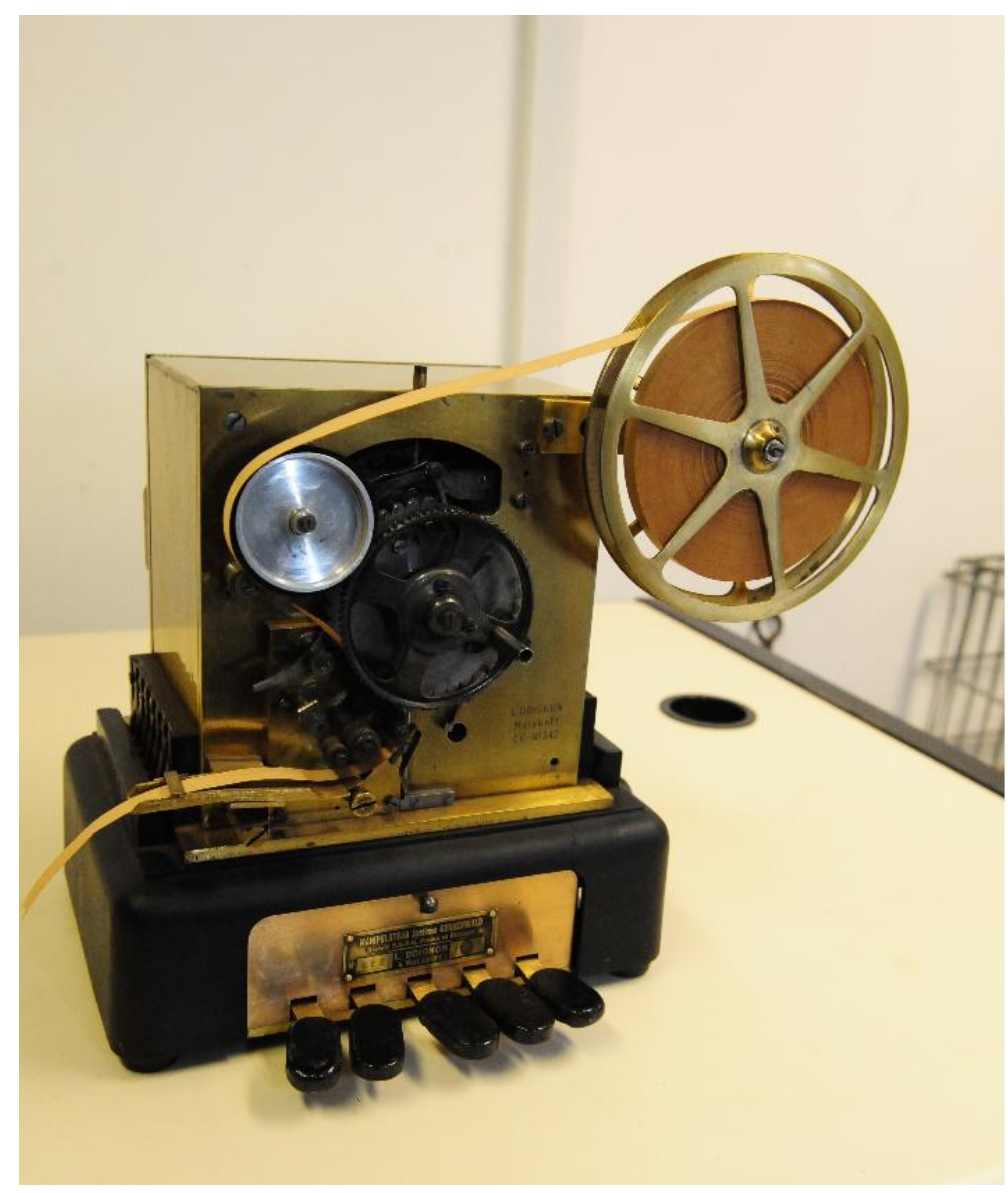

Foto: Jair Xavier - Acervo Museu Correios

Em 1892, em Campinas, utilizando uma válvula de três eletrodos, Roberto Landell de Moura captou e transmitiu a palavra humana através do espaço. Em 1904, Landell chegou a registrar nos Estados Unidos patentes de inventos como o 
transmissor de ondas, o telégrafo e o telefone sem fio. E, apesar de Marconi ter realizado a sua mais famosa experiência em 1895, três anos, portanto, depois do brasileiro, transmitindo inicialmente apenas sinais e não a voz, o cientista brasileiro não ficou mundialmente reconhecido por seus estudos pioneiros no âmbito das telecomunicações.

Figura 12 - Galvanômetros
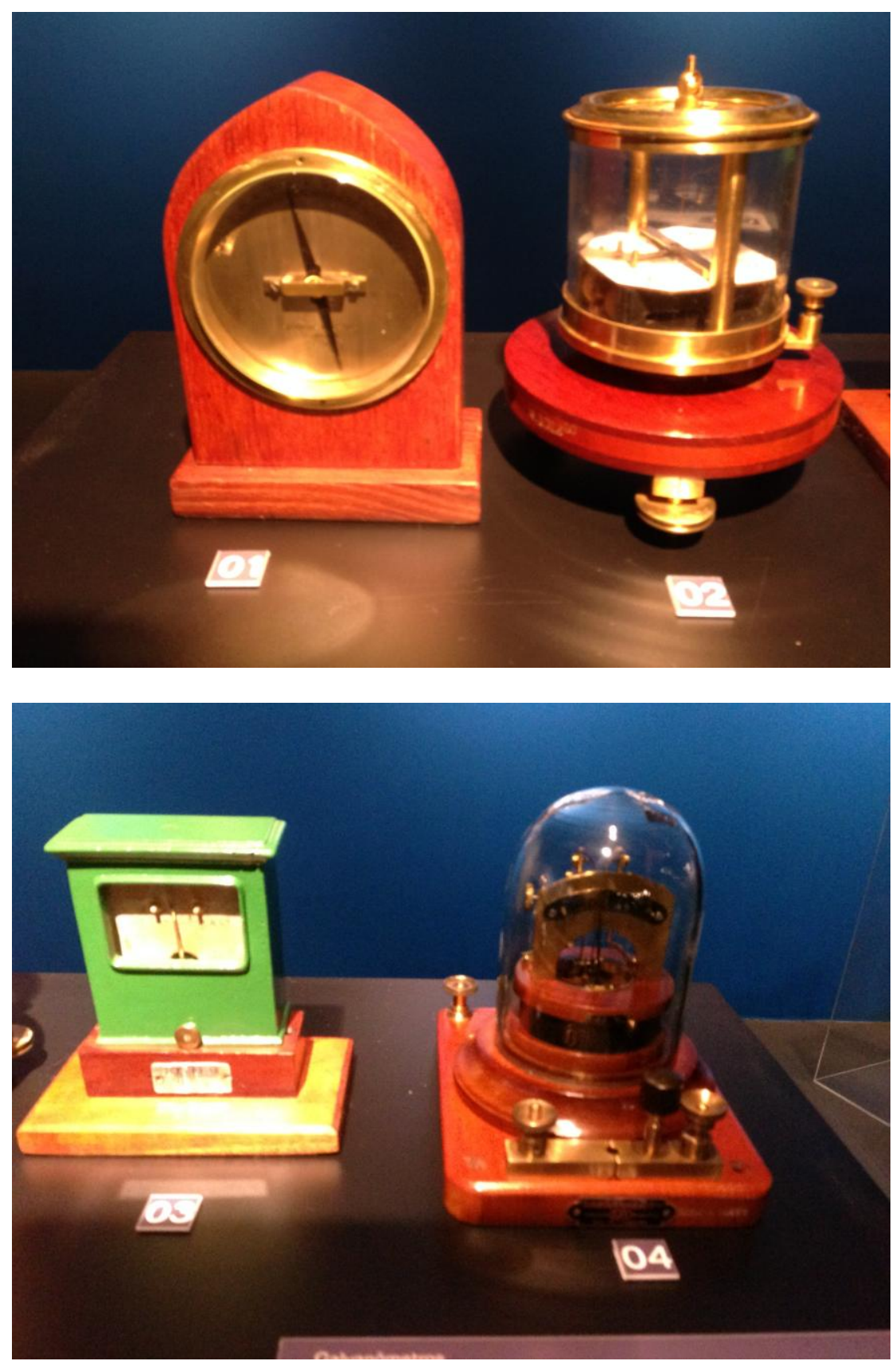

Foto: Bernardo Arribada - Acervo Museu Correios

As descobertas de Landell de Moura possibilitaram a transmissão de sinais sem a necessidade de conexões físicas, abrindo novas fronteiras para a 
comunicação humana. A partir desse momento passou a ser possível levar a comunicação sem fio a lugares inóspitos, como a Amazônia, em que a instalação e manutenção de postes e cabos eram caras e praticamente impossíveis.

Os aparelho telegráfico foram acompanhando os avanços e as necessidades tecnológicas, culminando em redes de telecomunicações, como a rede Gentex. Esses aparelhos seriam os últimos "telégrafos" instalados, sendo substituídos pelas redes computadorizadas.

Figura 13 - Aparelho Telex

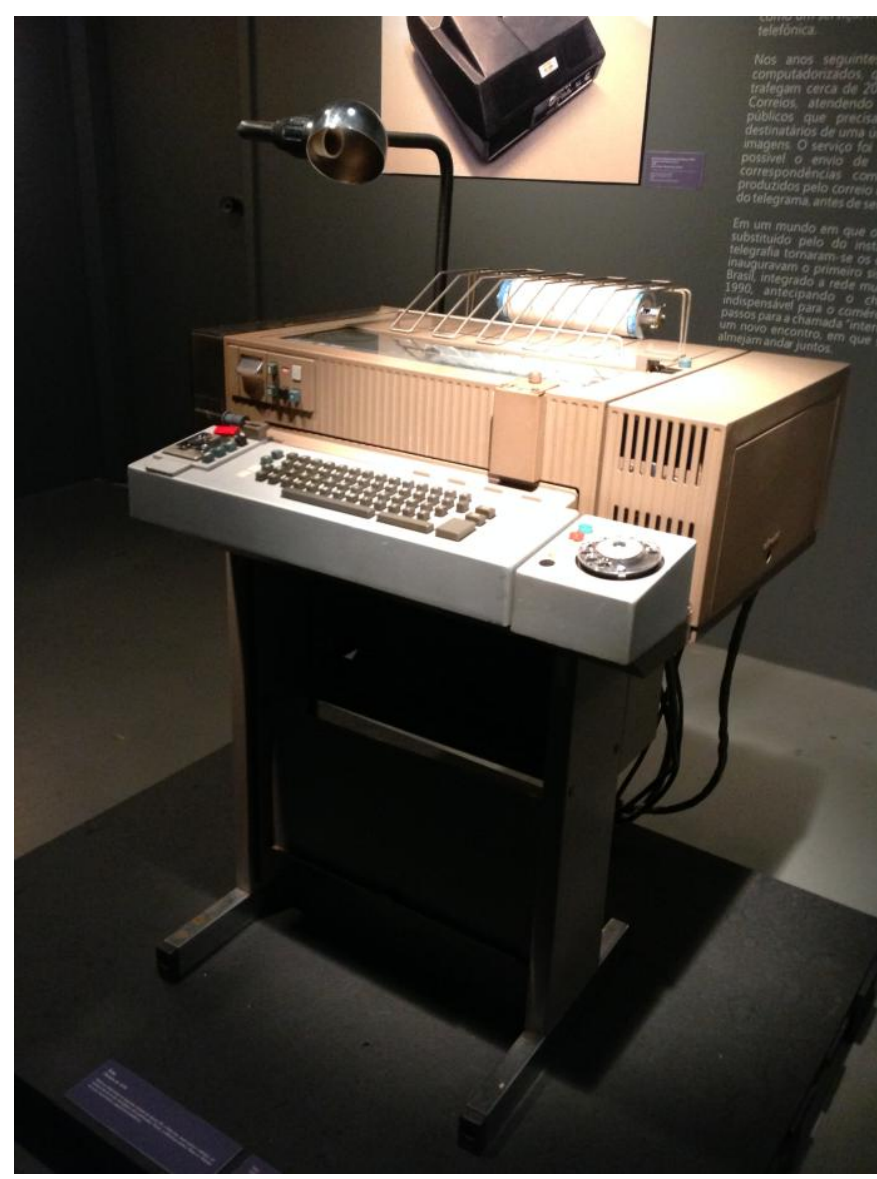

Foto: Bernardo Arribada - Acervo Museu Correios

Atualmente, a coleção telegráfica do Museu Correios é composta por objetos que compreendem a história da telegrafia, desde seus primórdios até as últimas décadas do século XX. Esses equipamentos, ao serem tratados pelo processo de musealização - quando são destituídos de sua função original e tornam-se objetos museológicos - objetos-documentos (LIMA, D., 2008) - permitem entender, junto ao densenvolvimento histórico brasileiro, o progresso da ciência e da tecnologia nacional. 
Sturchio (1988, p. 370-371, tradução nossa) identifica que os

Estudantes de Arqueologia Industrial, Antropologia Cultural, Arte e Arquitetura, e da História da Tecnologia tem prestado crescente atenção aos artefatos que Thomas Hugues uma vez denominou de 'cultura congelada'. Estudando os contextos nos quais máquinas, edifícios, e outros elementos da paisagem cultural são concebidos, construídos, e utilizados rendeu importantes insights sobre as relações de poder, patronagem, e da prática social do passado. Historiadores da tecnologia, em particular, começaram a apreciar o valor de tomar os artefatos com seriedade, como na importante interpretação feita por David Noble sobre as máquinas controladas numericamente, ou a feita por Larry Owen sobre o estudo do analisador diferencial.

Abordagens similares - focando sobre o artefato como um espelho da técnica, do social, do político e dos interesses e significados econômicos - têm grande potencial para os historiadores da ciência. Certos instrumentos e técnicas já estão inseparavelmente ligados ao nosso entendimento dos temas-chaves da história da ciência, como elos cruciais que fazem mediação entre o cientista e os 'fatos' da natureza - como o telescópio e a astronomia do século XVII, o espectroscópio e a astrofísica do século XIX, a Drosophila e a genética do século $X X$, o aceleradores de partículas e a moderna física nuclear e de alta energia. $O$ estudo da interação entre 0 instrumento e o experimento também lançam luz sobre a emergência da 'grande ciência' do século XX. O advento de novos instrumentos do medidor de $\mathrm{pH}$, do fotoespectrômetro, e da ultracentrífuga ao espectômetro de massa, túnel de vento, acelerdor de partículas e sintetizador de proteínas - influenciou a economia política da prática experimental e da cultura do laboratório de forma dramática, fornecendo um impulso para os chefes de laboratórios atuarem como cientistas-empresários liderando um time de pesquisadores associados funcionalmente distintos em uma indústria de capitalintensivo e quase empresarial. ${ }^{65}$

65 Students of industrial archaeology, cultural anthropology, art and architecture, and the history of technology have paid increasing attention to artifacts as what Thomas Hughes once termed 'congealed culture'. Studying the contexts in which machines, buildings, and other elements of the cultural landscape are designed, constructed, and used has yielded important insights into the relationships of power, patronage, and social practice in the past. Historians of technology in particular have begun to appreciate the value of taking artifacts seriously, as in David Noble's important interpretation of the history of numerically controlled machine tools, or Larry Owens's study of the differential analyzer.

Similar approaches - focusing on the artifact as a mirror of technical, social, political, and economic interests and meanings - have great potential for the historian of science. Certain instruments and techniques are already inextricably tied to our understanding of key topics in history of science, as crucial mediating links between the scientist and nature's 'facts' - the telescope and seventeenthcentury astronomy, the spectroscope and nineteenth-century astrophysics, Drosophila and twentiethcentury genetics, the particle accelerator and modern high-energy physics. Study of the interplay of instruments and experiment also sheds light on the emergence of 'big science' in the twentieth century. The advent of new instruments - from $\mathrm{pH}$ meter, the spectrophotometer, and the ultracentrifuge to the mass spectrometer, wind tunnel, particle accelerator, and protein synthesizer has influenced the political economy of experimental practice and the culture of the laboratory in dramatic ways, by providing a push toward the laboratory head as scientist-entrepreneur leading a team of functionally distinct research associates in a capital-intensive and almost industrial enterprise. 
O presente trabalho, corrobora com Sturchio, ao reconhecer que, a partir de objetos de C\&T, é possível recuperar informações importantes acerca da história da tecnologia e do ambiente sócio-econômico nacional, além de "[...] determinar o que deve ser feito, também determina, em uma certa medida, o que pode ser 'pensado'." (GRANATO et. al., 2007. n/p), ou seja, sua função e seu contexto.

Assim, a pesquisa procurou analisar os modelos de leitura de objetos, indicados por Susan Pearce para utilização em âmbito museológico, e apresentados no ponto 2.3. dessa fundamentação teórica, adaptando-os para coleções científicas e tecnológicas, tendo como finalidade a problematização do acervo do Museu Correios, utilizando o arcabouço teórico da cultura material. Buscou-se, também, a partir da identificação de um possível modelo específico, verificar a necessidade de alterações para melhor adequação ao objeto de estudo. "Esse trajeto pode ser explicado pela inexistência de um modelo adequado para a leitura de objetos de C\&T" (GRANATO et. al., 2007. n/p.) e justificado na importância do objeto científico como fonte documental para a História das Ciências e das Técnicas.

Os resultados da pesquisa buscaram, baseado na perspectiva teoria e prática explicitada nessa revisão, contribuir com os estudos e pesquisas em coleções museológicas, relacionadas ao exercício da Documentação aplicada à Museologia.

Figura 14 - Caixas de Resistência

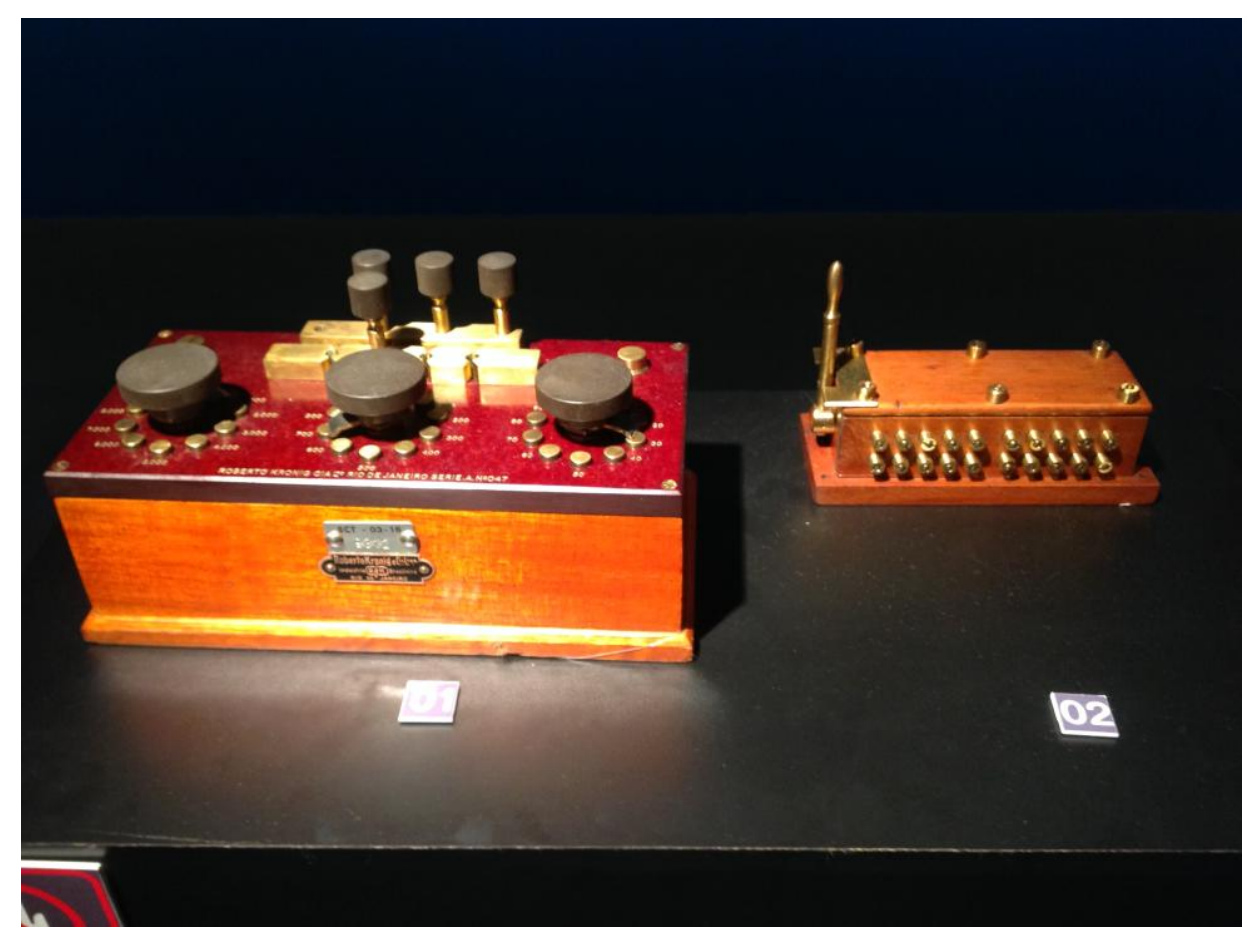

Foto: Bernardo Arribada - Acervo Museu Correios 
Figura 15 - Mostruário de Cabos Submarinos

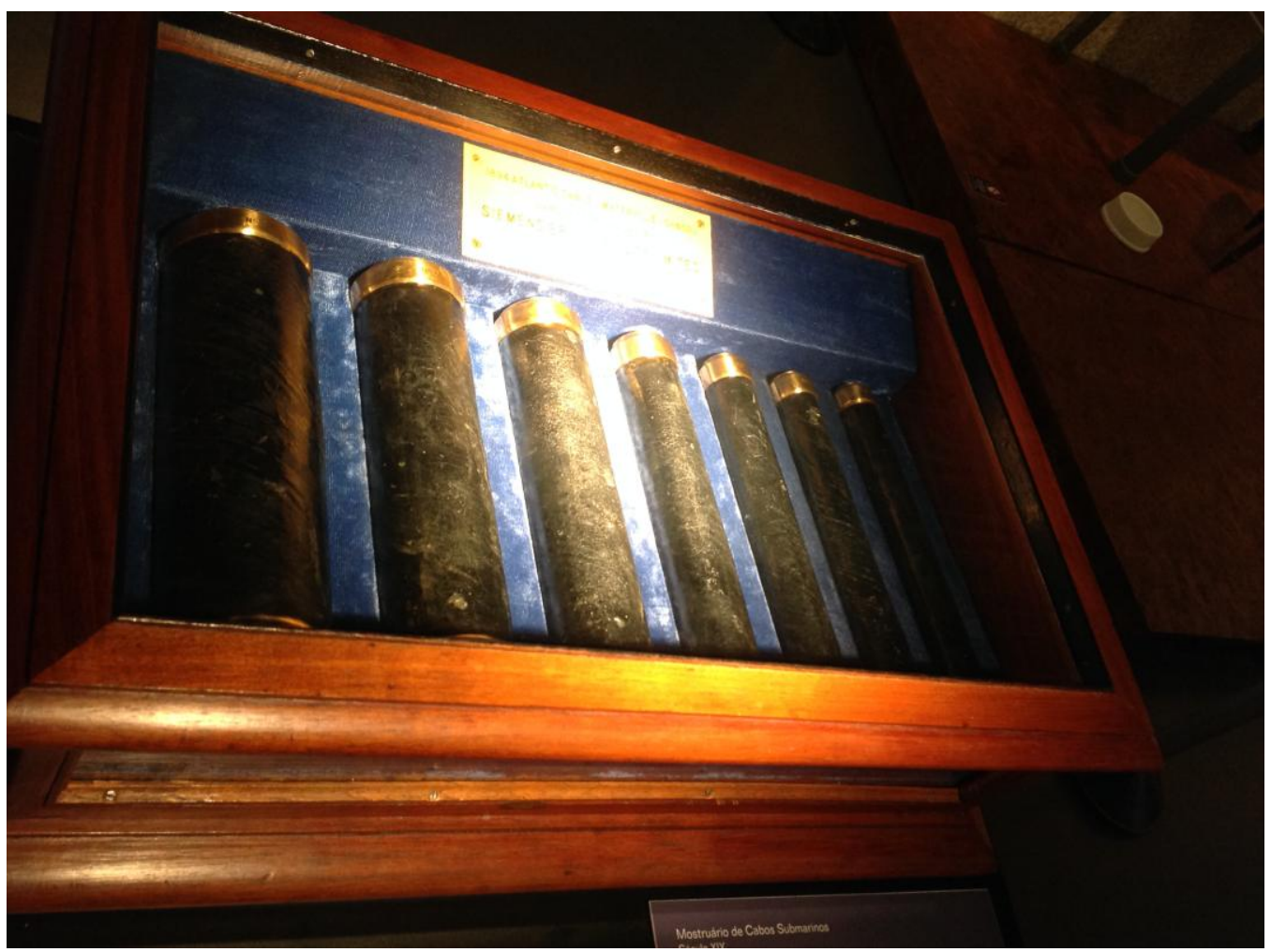

Foto: Bernardo Arribada - Acervo Museu Correios

Figura 16 - Isoladores

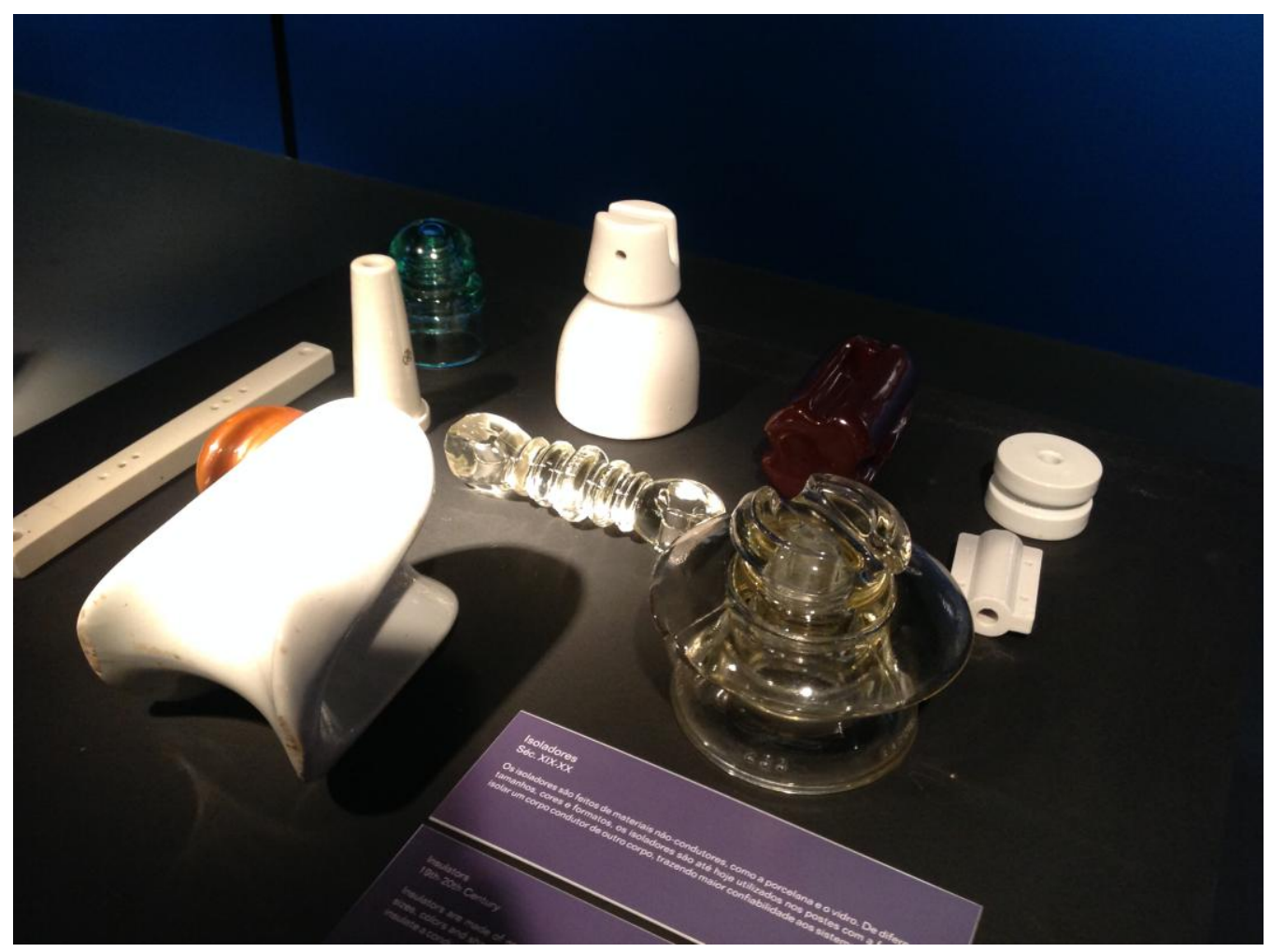

Foto: Bernardo Arribada - Acervo Museu Correios 
Figura 17 - Telégrafo de Campanha - Coleção Mal. Rondon

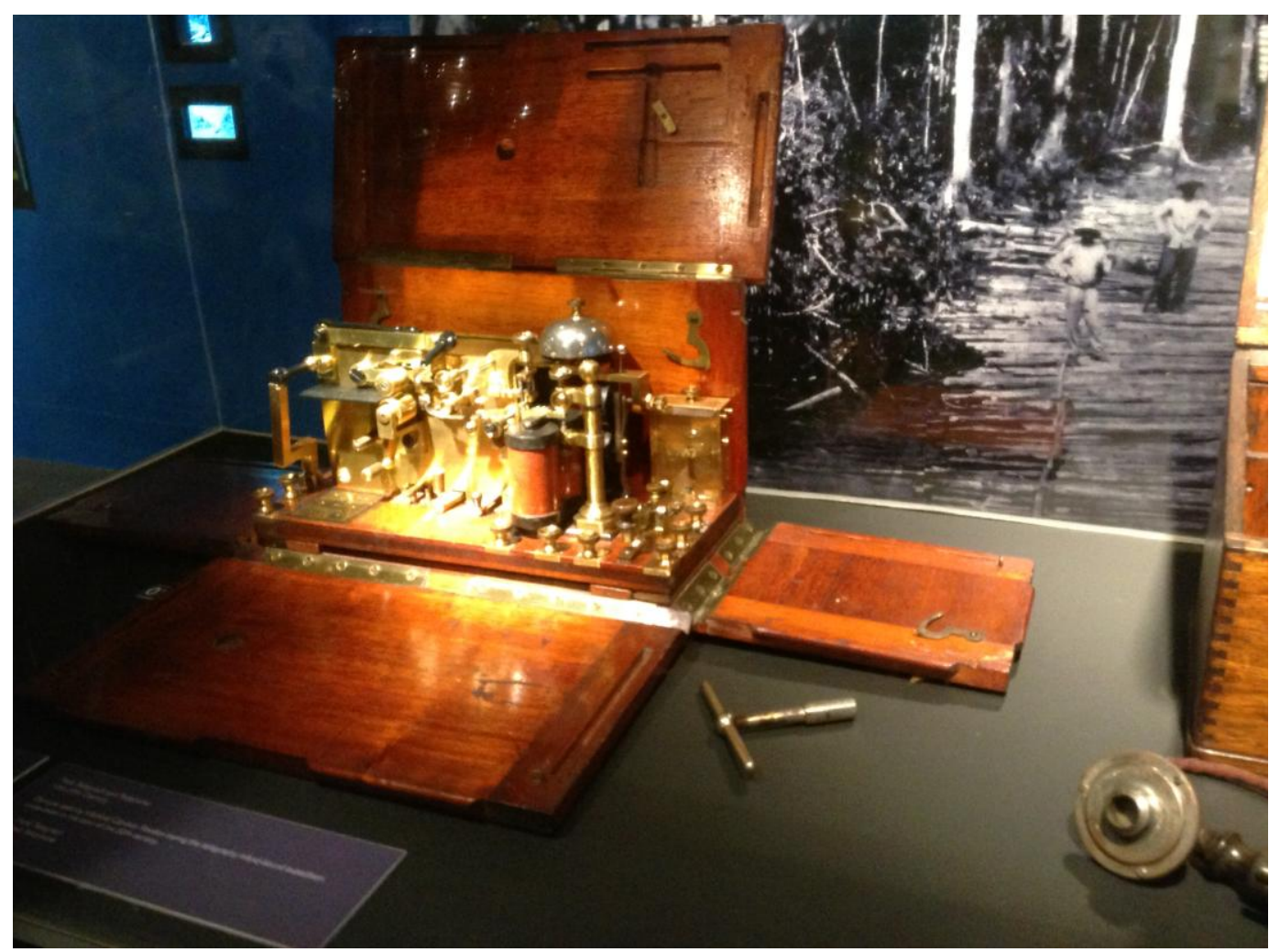

Foto: Bernardo Arribada - Acervo Museu Correios

Figura 18 - Telefone de Campanha - Coleção Mal. Rondon

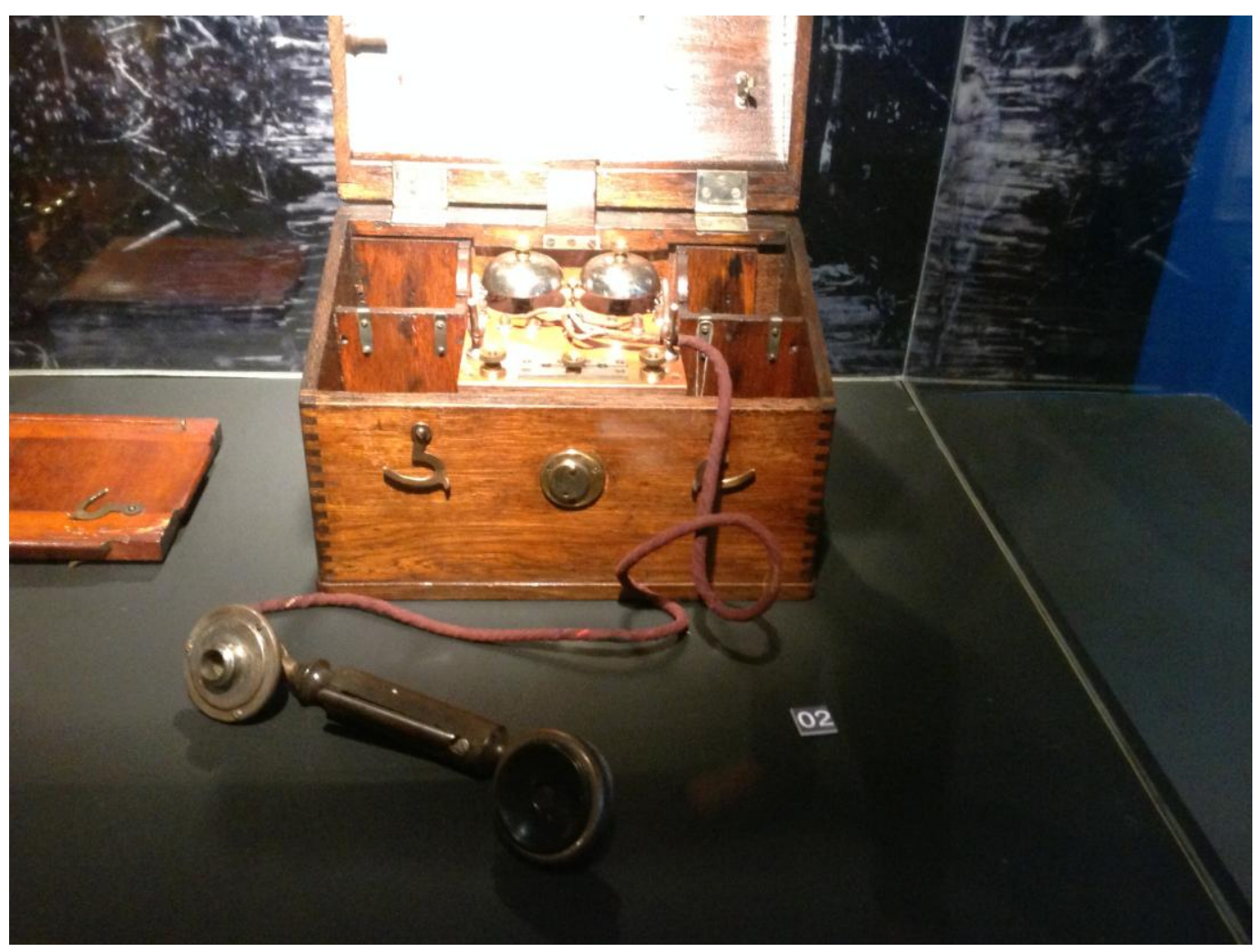

Foto: Bernardo Arribada - Acervo Museu Correios 
Figura 19 - Teodolito - Coleção Mal. Rondon

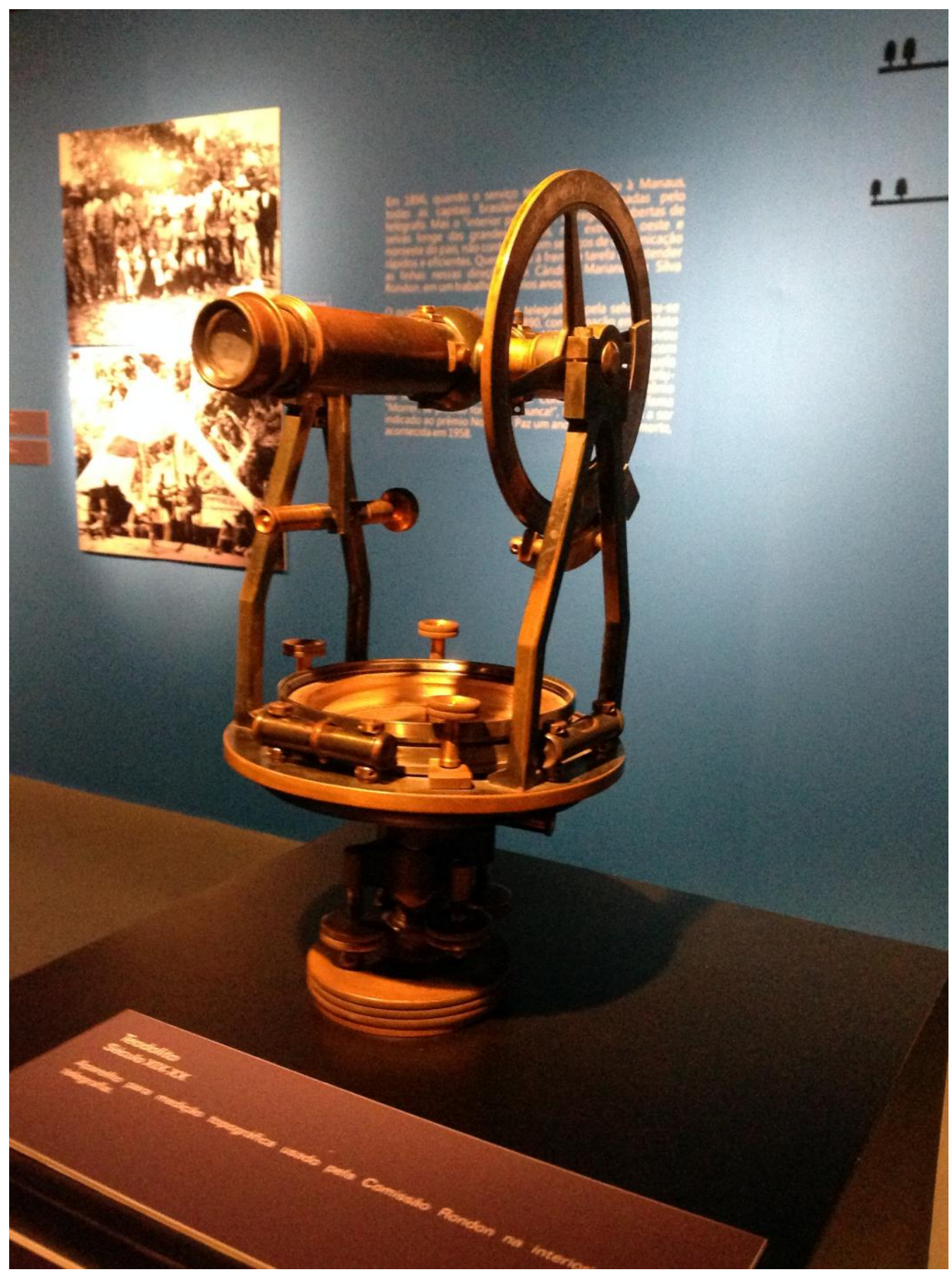

Foto: Bernardo Arribada - Acervo Museu Correios 


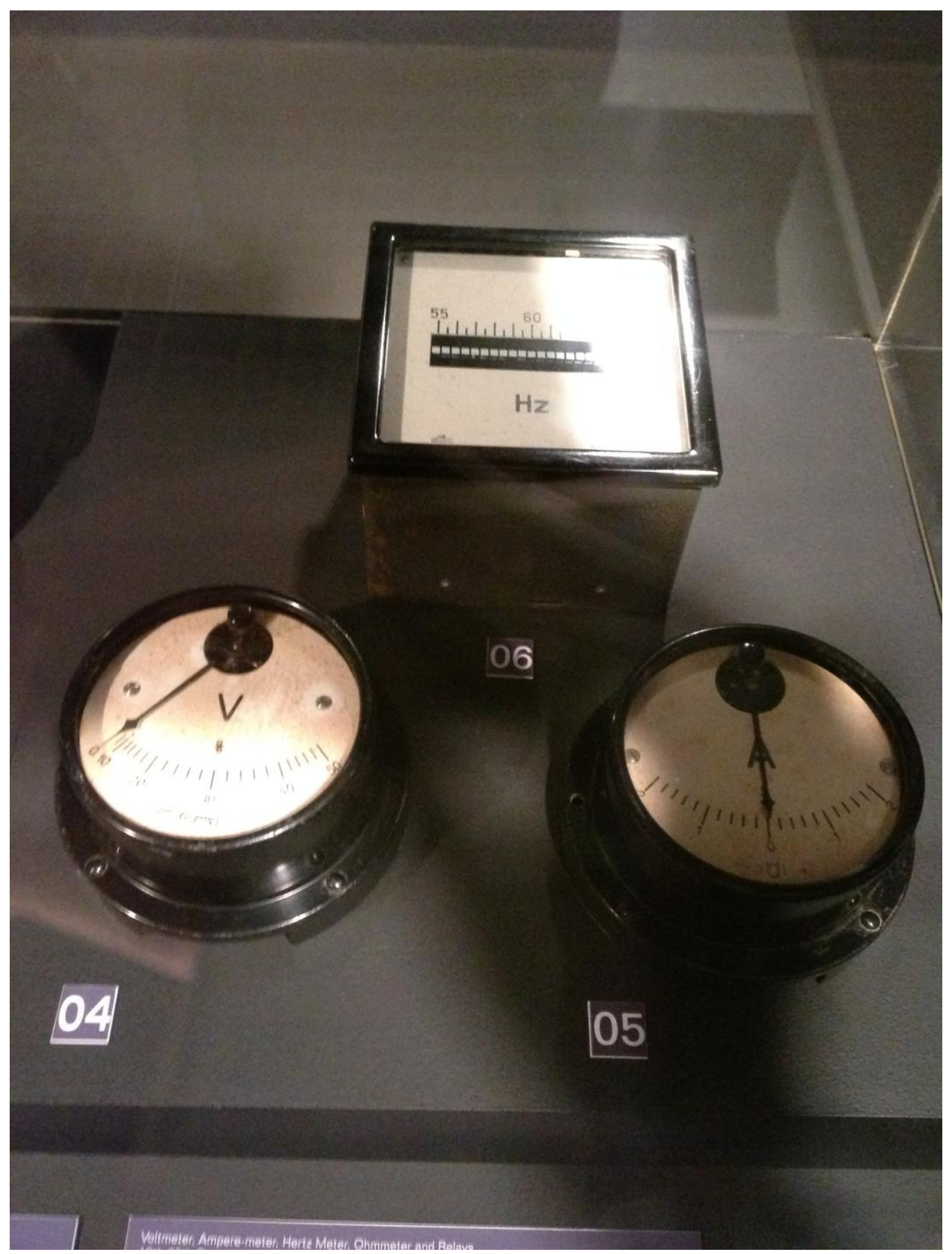

Foto: Bernardo Arribada - Acervo Museu Correios 
Figura 21 - Aparelhagem para Radiotelegrafia

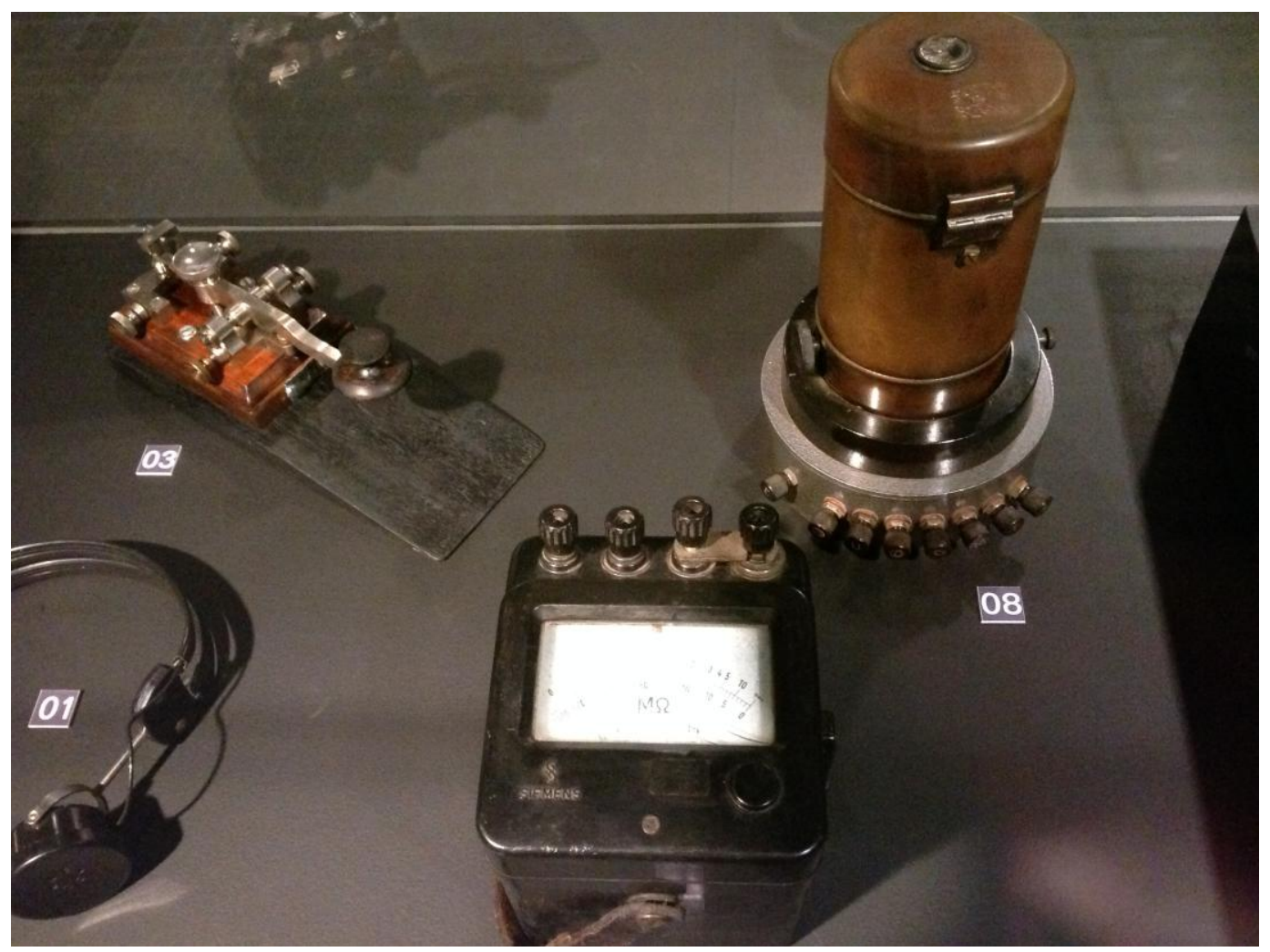

Foto: Bernardo Arribada - Acervo Museu Correios

\section{Figura 22 - Válvulas Termiônicas}

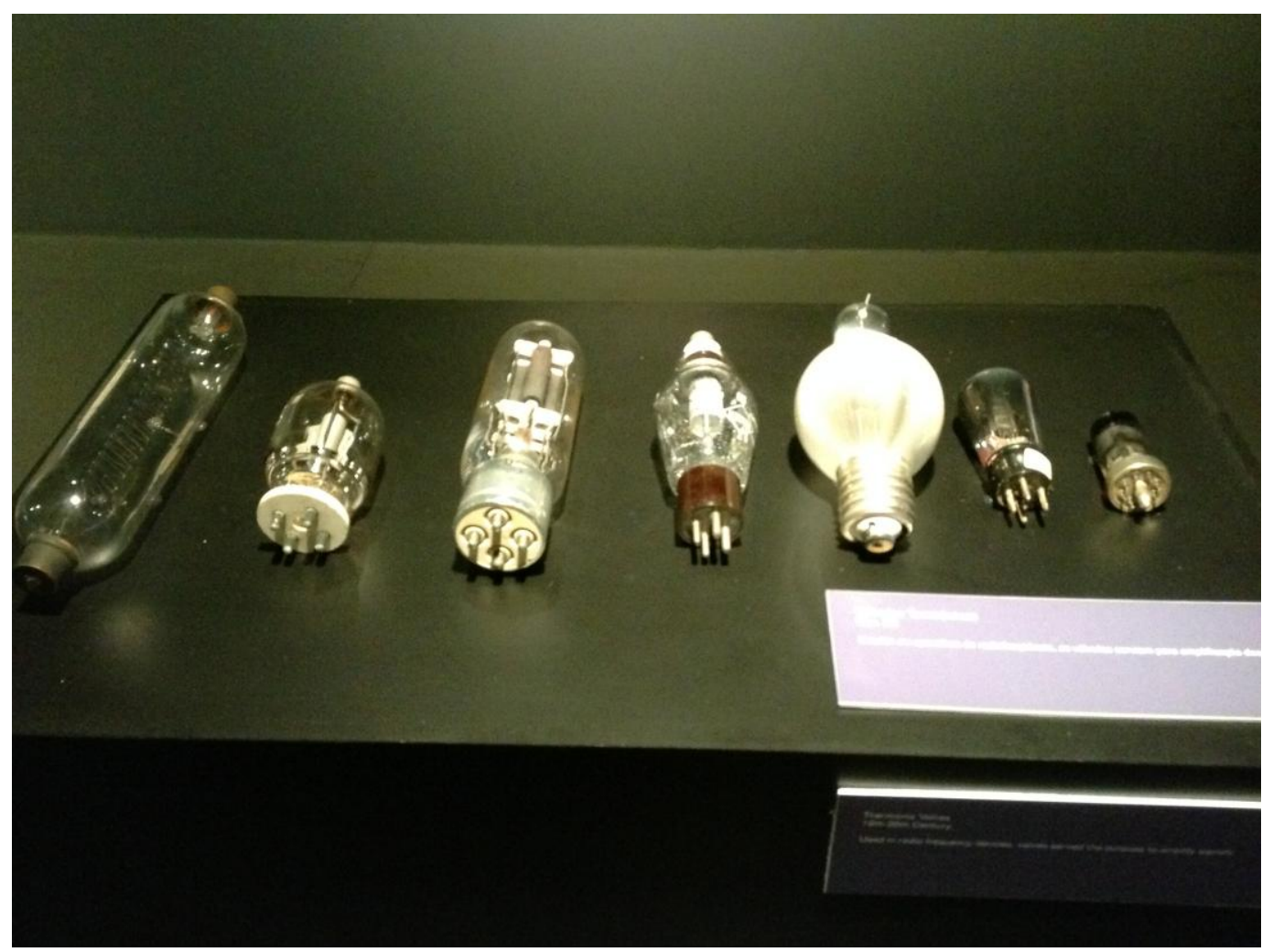

Foto: Bernardo Arribada - Acervo Museu Correios 
Figura 23 - Teletipo

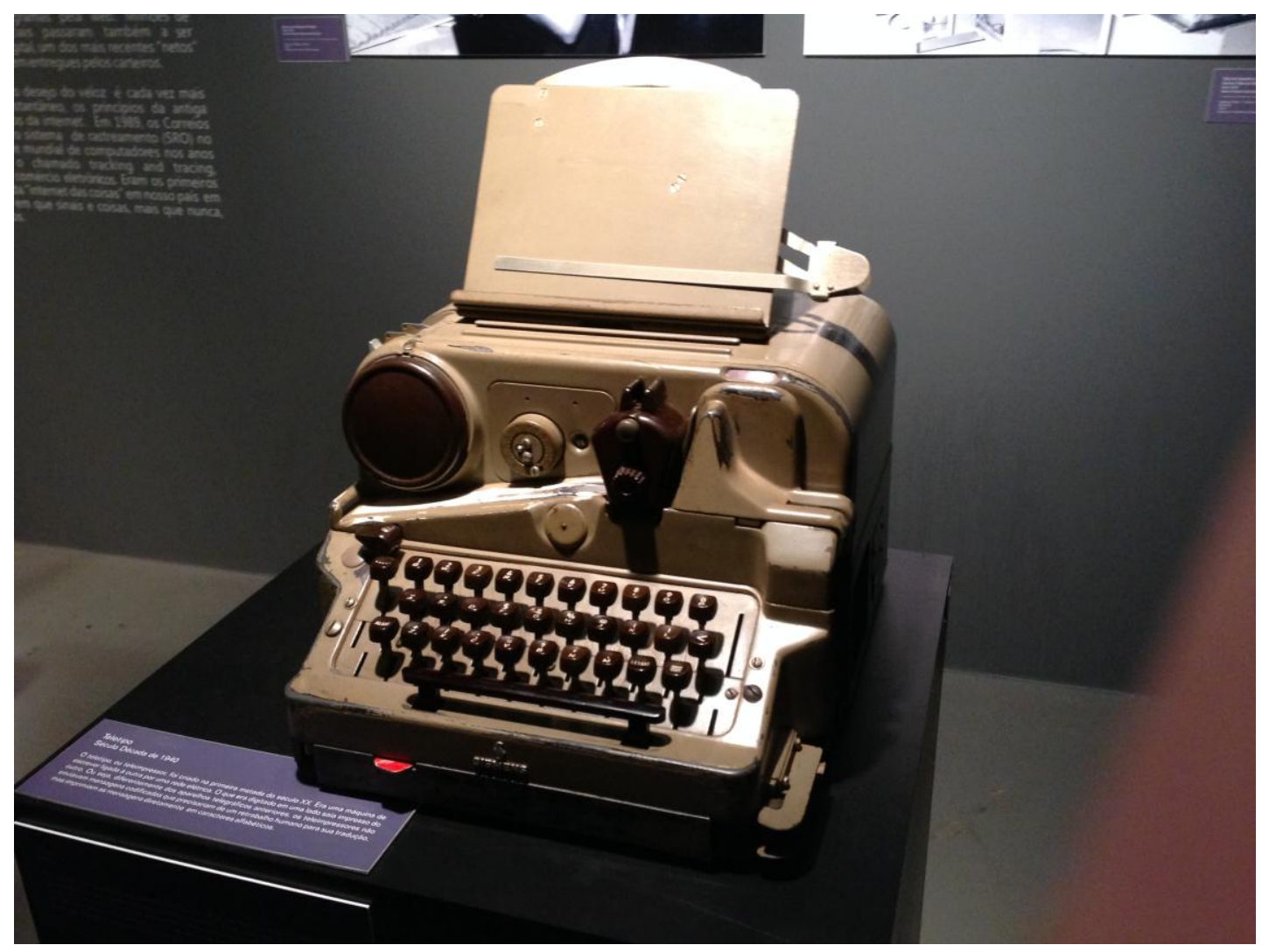

Foto: Bernardo Arribada - Acervo Museu Correios 


\section{Metodologia}

Antes de identificar os aspectos teóricos e práticos da pesquisa, faz-se necessário delimitar seu ambiente. Essa pesquisa toma forma no âmbito da coleção telegráfica do Museu Correios (MC). O MC, cujo histórico remonta aos fins do século XIX, atualmente, está localizado no Setor Comercial Sul, centro de Brasília, Distrito Federal.

Figura 24 - Museu Correios (Fachada)

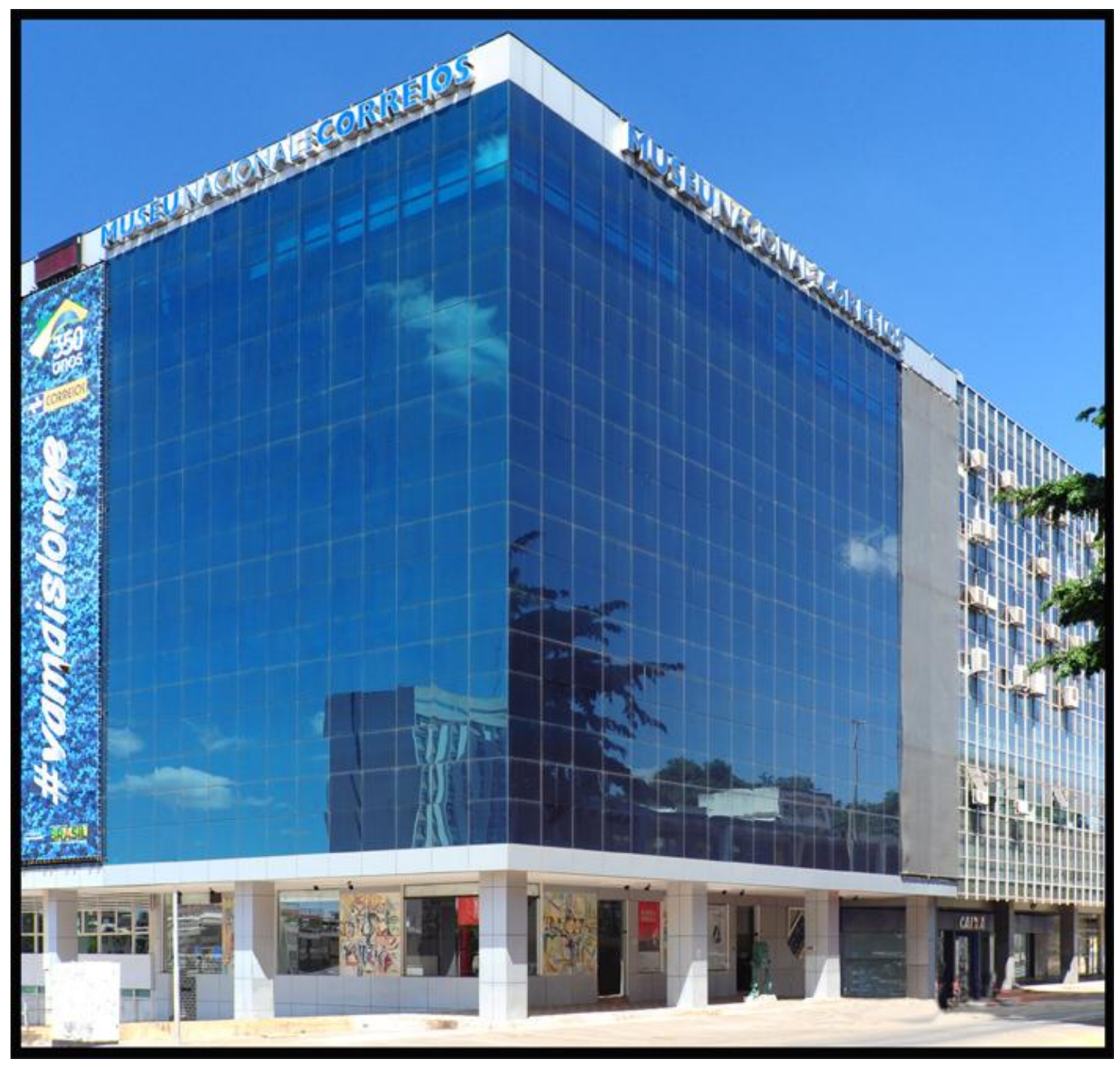

Foto: Jair Xavier - Acervo Museu Correios

A instituição disponibiliza 5 (cinco) andares para exposições temporárias e de longa duração. Conta, também, com um auditório onde acontecem eventos de cinema e música, além de um Centro de Documentação (CEDOC), composto por uma biblioteca e um arquivo. 
Figura 25 - Exposição de Longa Duração - Museu Correios

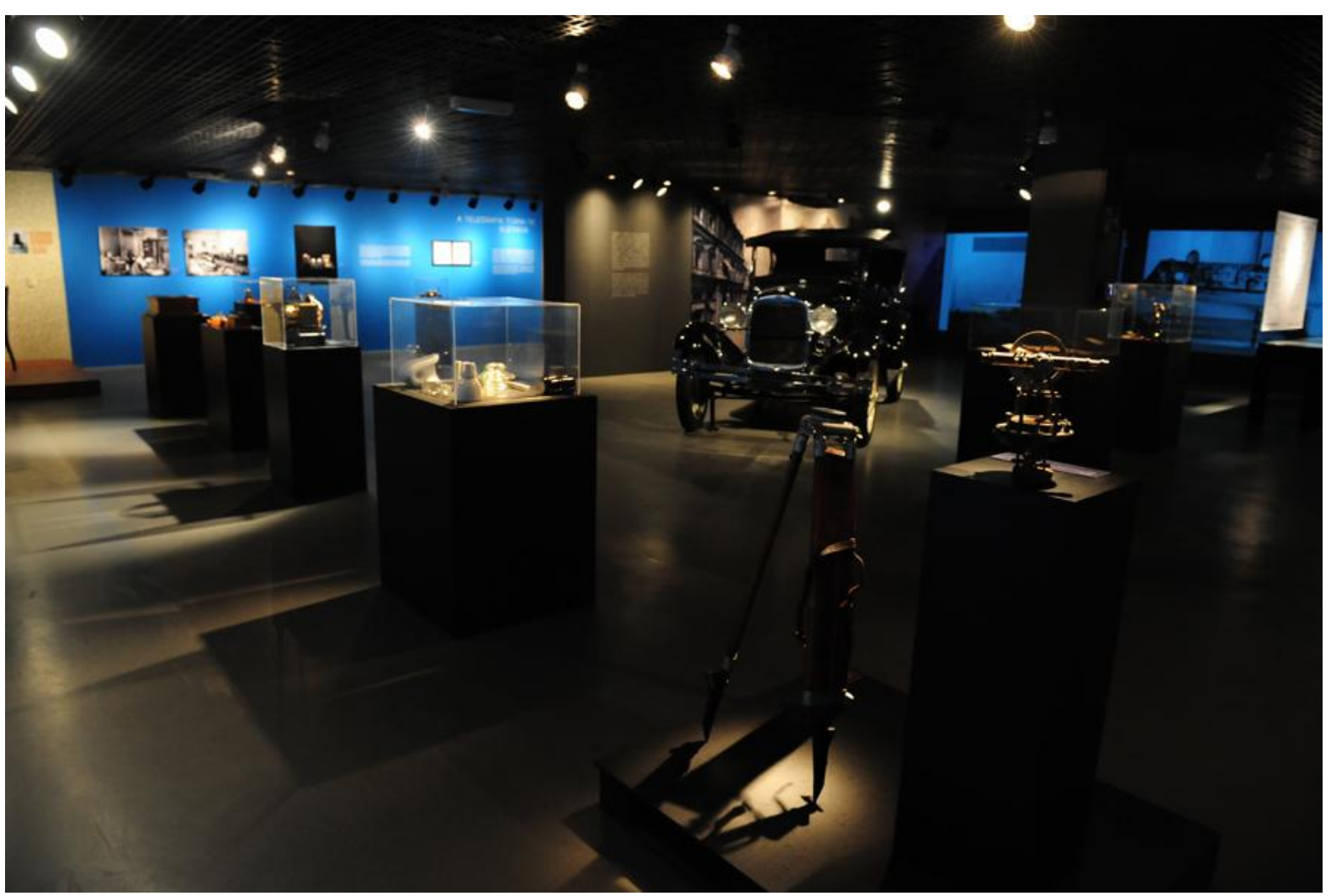

Foto: Jair Xavier - Acervo Museu Correios

Figura 26 - Exposição Temporária - Museu Correios

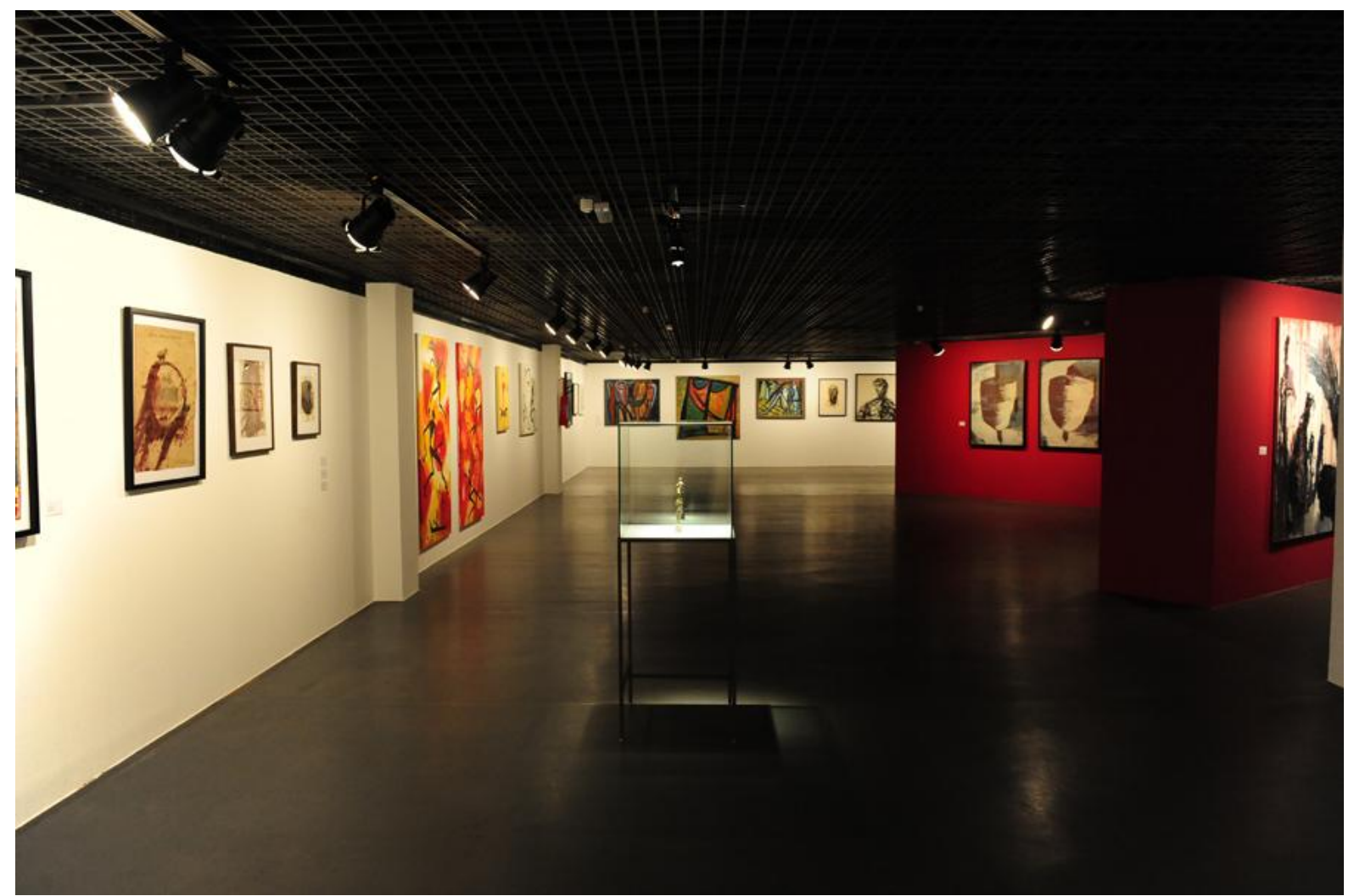

Foto: Jair Xavier - Acervo Museu Correios 
Figura 27 - Auditório - Museu Correios

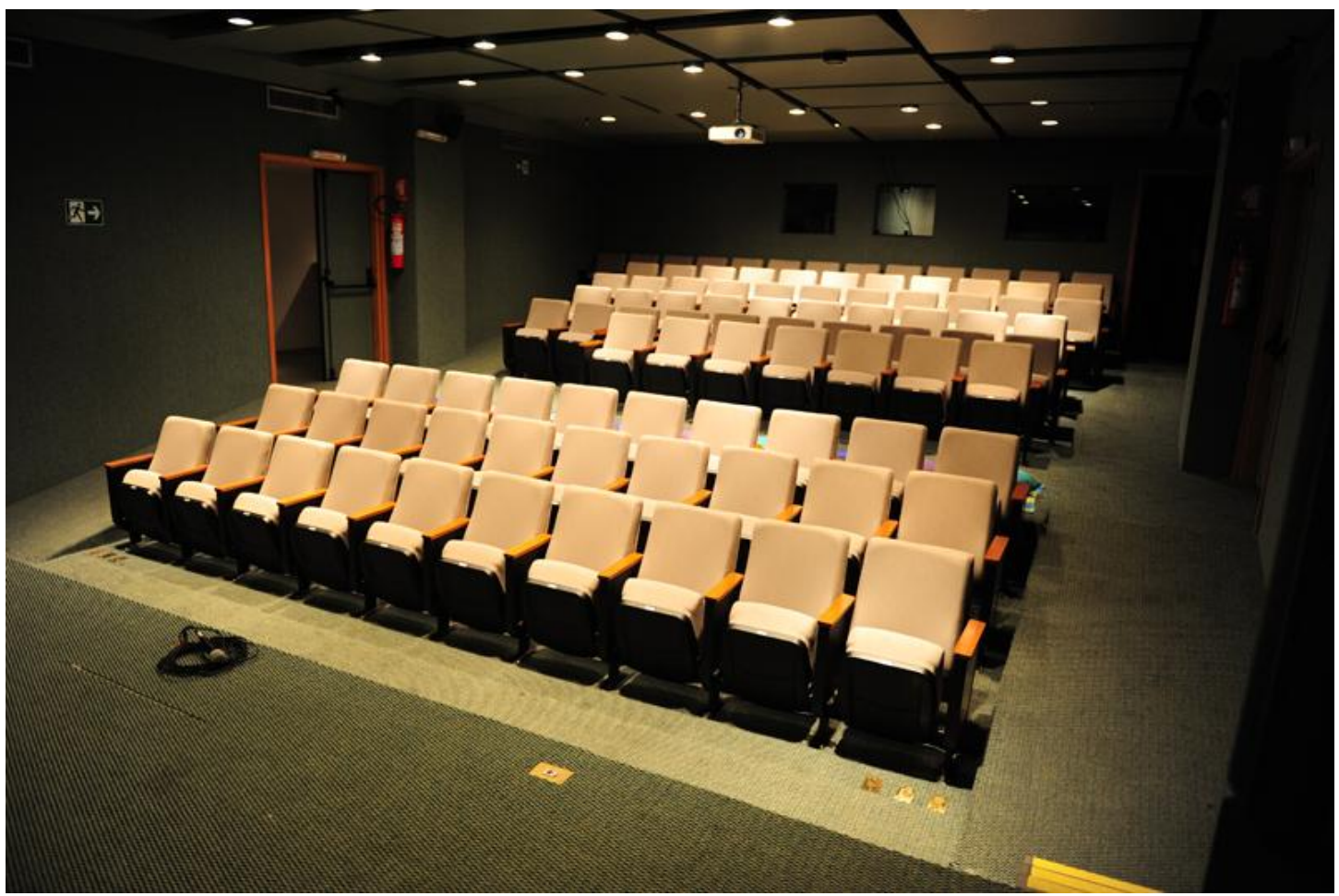

Foto: Jair Xavier - Acervo Museu Correios

Seu acervo, único em sua natureza, e que conta com mais de 2 milhões de peças, é composto, basicamente, por seis coleções, a saber:

- Coleção Postal: composta por objetos usados no serviço postal, como balanças, caixas de coleta, sacos e malas postais, uniforme de carteiros e estafetas, meios de transporte, máquinas de triagem e de franquear, mobiliário de agência, etc;

- Coleção Telegráfica: foco da pesquisa - composta por aparelhos telegráficos, amostra de cabos, aparelhos e ferramentas para manutenção das linhas, instrumentos científicos, etc;

- Coleção Filatélica: composta por selos e outros produtos filatélicos como inteiros postais e matrizes para impressão de selos. Composta por uma coleção nacional e uma internacional, com selos enviados pela União Postal Universal;

- Coleção de Marcofilia e Sigilografia: composta por carimbos e sinetes desde a época imperial; 
- Coleção de Artes Plásticas: pinturas e esculturas doadas ao museu;

- Coleção de Memorabilia: composta por objetos oriundos de projetos de patrocínio da $\mathrm{ECT}^{66}$, como bolas autografadas pelo tenista Gustavo Kuerten e camisetas de exposições, e eventos, como competições e prêmios.

Para guarda de suas coleções, o MC dispõe de duas reservas técnicas: uma para objetos de pequeno porte, e que tenham passado por processos de higienização ou restauro, além de comportar a coleção de Filatelia nacional; e outra, nas dependências da Universidade Corporativa dos Correios, no Setor de Clubes Norte, onde são guardados objetos de grande porte - como meios de transporte ou máquinas de triagem usadas no operacional da empresa - e objetos que não tenham passado por processos de higienização. A coleção de Filatelia internacional fica guardada nas dependências do CEDOC.

Figura 28 - Reserva Técnica - Museu Correios

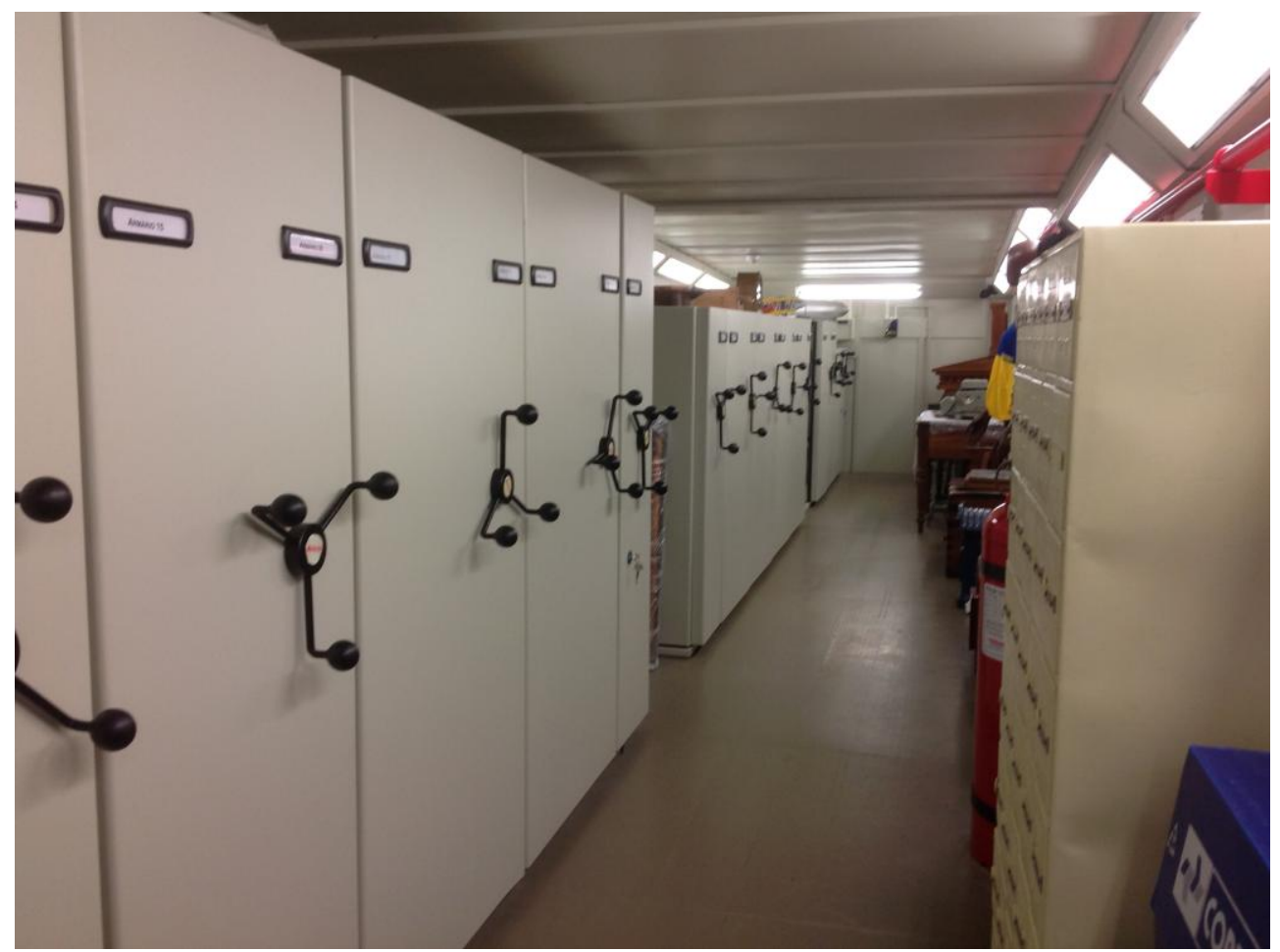

Foto: Bernardo Arribada

${ }^{66}$ Além do DEGEC, a ECT tem outro departamento em sua estrutura organizacional responsável por seus projetos patrocínios: o Departamento de Comunicação Estratégica (DECOE) que fica responsável por grandes projetos como o Rock in Rio, o Lollapalooza e os patrocínios desportivos Desportos Aquáticos, Tênis e Futsal. 


\section{Figura 29 - Reserva Técnica - Museu Correios (Detalhe)}

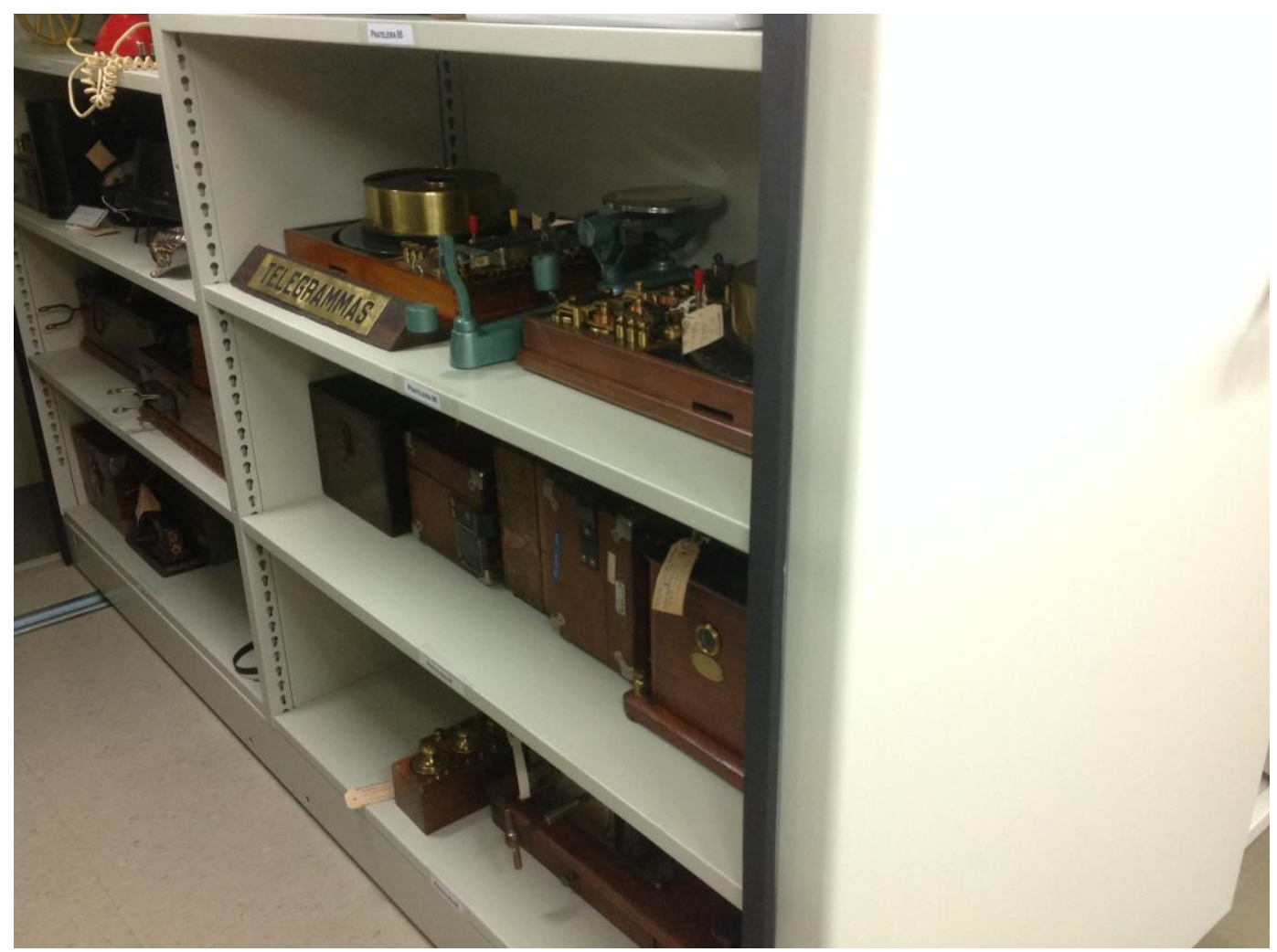

Foto: Bernardo Arribada

O acervo bibliográfico e arquivístico, que compõem o Centro de Documentação (CEDOC), também são extremamente representativos. A Biblioteca do MC é composta por livros cuja temática gira em torno da Historia Postal e Telegráfica, nacional e internacional, da história da Empresa, além de exemplares sobre Filatelia, Museologia, dicionários e catálogos de exposições.

O Arquivo Histórico do Museu Correios é composto por uma coleção de fotografias, editais de selos e carimbos, relatórios e boletins, documentos, microfilmes, fitas VHS e Betacam, DVD's, além de todo o acervo do projeto de Memória Oral. 


\section{Figura 30 - Biblioteca - Museu Correios}

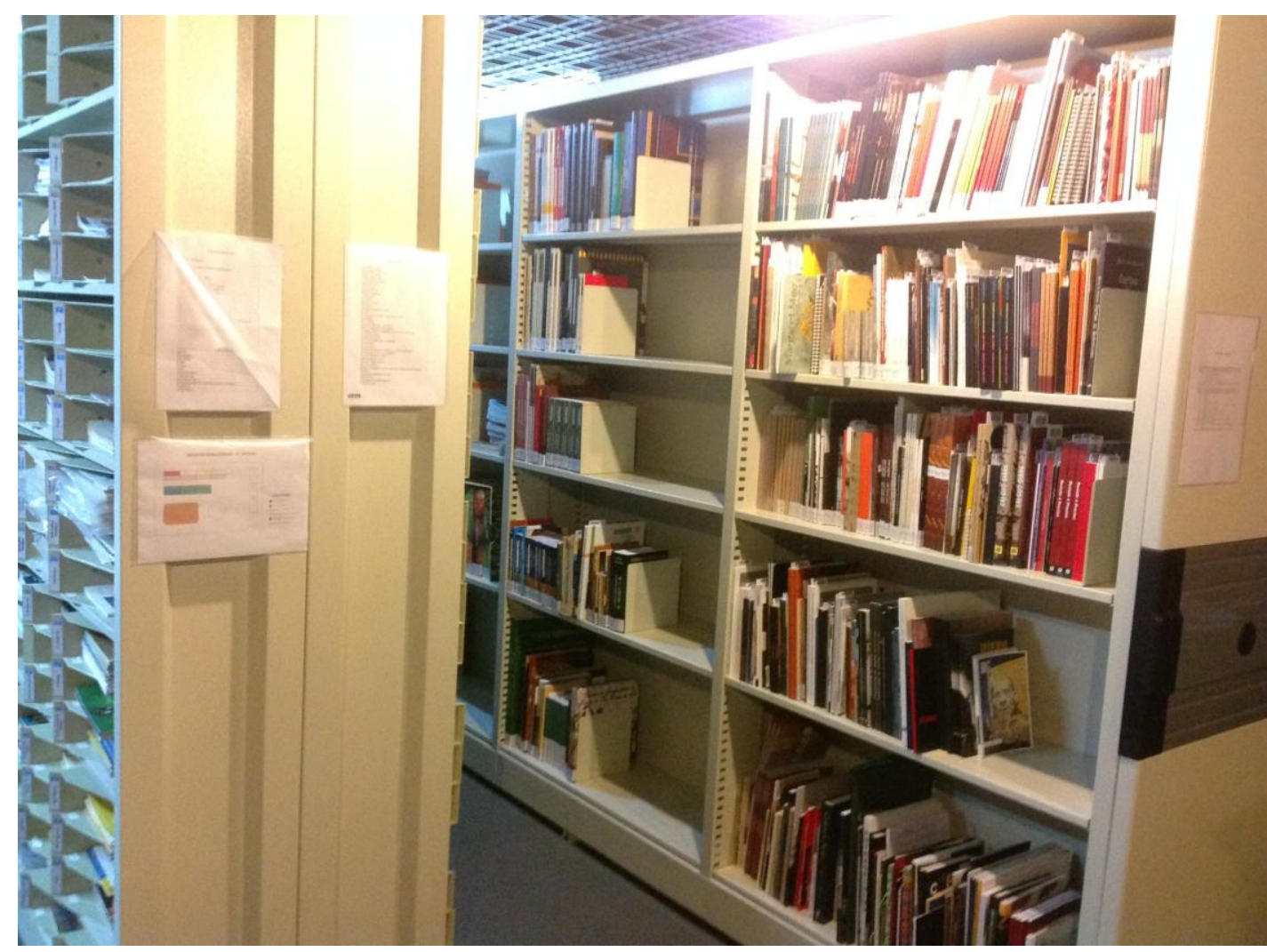

Foto: Bernardo Arribada

Figura 31 - Arquivo - Museu Correios

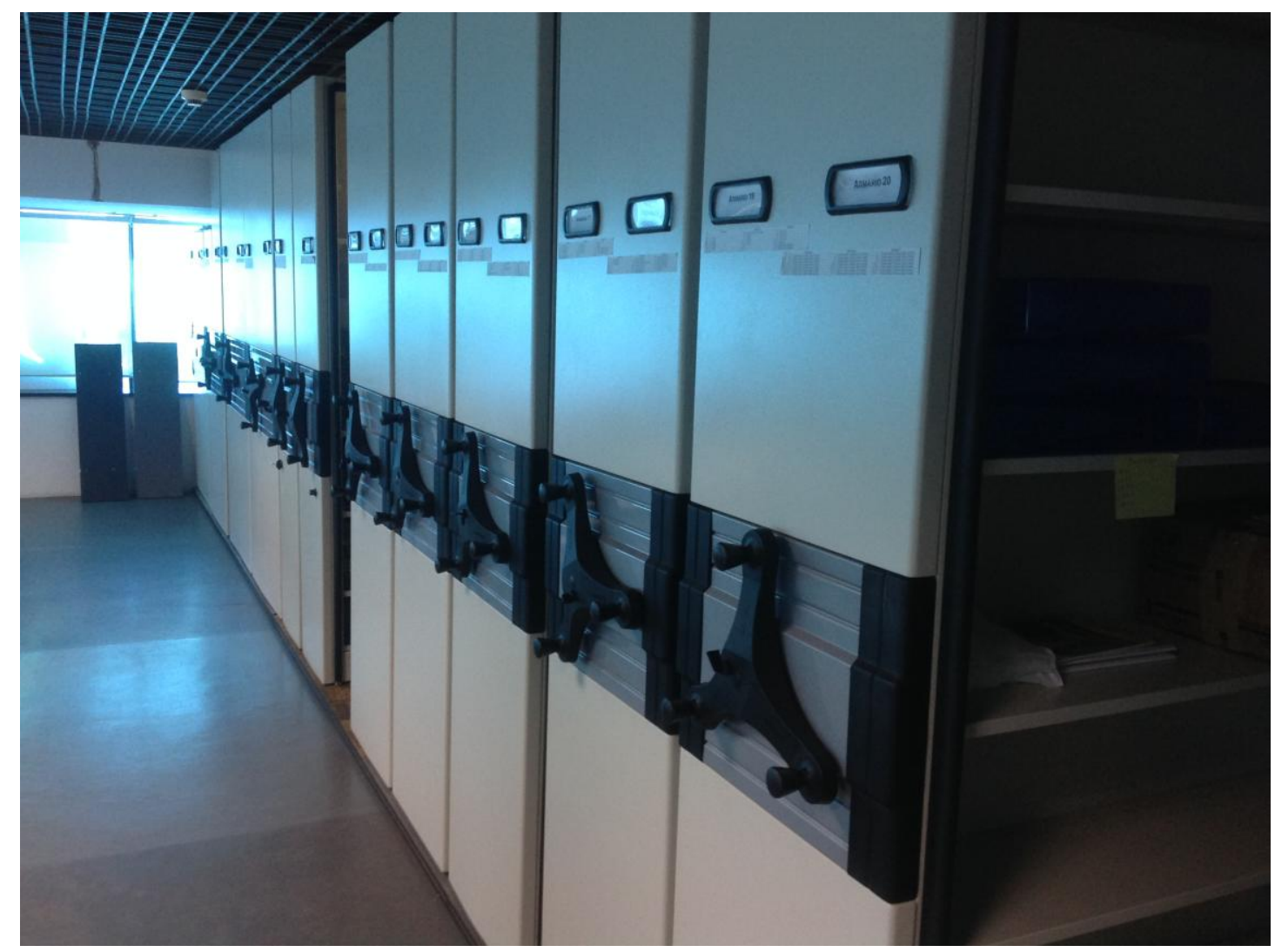

Foto: Bernardo Arribada 
A presente pesquisa se debruçou sobre a coleção telegráfica, formada por conjuntos de instrumentos tecnológicos como: aparelhagem e manipuladores morse, relés (relais), sounders, condensadores, baterias, telefones, teleimpressores, aparelhos de Telex, entre outros equipamentos. Como visto anteriormente, essa gama variada de objetos permite entender, junto ao progresso da ciência e da tecnologia, a importância do seu uso em acontecimentos históricos da vida brasileira, como a participação da telegrafia para o envio de informações na Guerra do Paraguai; a expansão territorial para o interior do país e intensificada na virada do século XIX para o XX, episódio no qual a figura do Marechal Candido Mariano Rondon foi marcante na implantação de uma rede de comunicação por telégrafo e radiotelégrafo; e, também, os diferentes sistemas de codificação utilizados na transmissão das mensagens.

\subsection{Aspectos Teóricos}

A pesquisa "Tratamento Informacional da Coleção Telegráfica do Museu Correios: análise sob a perspectiva científica, tecnológica e de cultura material" teve como propósito ser um estudo descritivo à medida em que buscou verificar e descrever características de um dado fenômeno - Documentação em Museus, Documentação de Acervo de Ciência e Tecnologia e Documentação no Museu Correios. Outra característica que demonstra o propósito descritivo do presente estudo é a não-tentativa de estabelecer causa/efeito de qualquer evento, se limitando a observar um problema - a falta de metodologia para análise e organização da informação/documentação do acervo de telegrafia no Museu Correios - propondo estudos descritivos - e, de certa perspectiva, corretivos - que, nas palavras de Uma Sekaran, buscarão

[...] oferecer aos pesquisadores um perfil ou descrever aspectos relevantes dos fenômeno de interesse a partir de uma visão individual, organizacional, de orientação industrial, ou de outra perspectiva. Em muitos casos, tal informação pode ser vital antes mesmo de se considerar certas ações corretivas. (SEKARAN, 2003, p. 122 , tradução nossa) ${ }^{67}$.

67 To offer to the researcher a profile or to describe relevant aspects of the phenomena of interest from an individual, organizational, industry-oriented, or other perspective. In many cases, such information may be vital before even considering certain corrective steps. 
A abordagem que se pretendeu tomar para o desenvolvimento do estudo é a abordagem qualitativa, pois o estudo se configurou como um meio para explorar e entender o significado que os indivíduos ou os grupos atribuem a um problema social ou humano, específica e profundamente. Creswell (2010, p. 26) indica que as pesquisas qualitativas são processos que envolvem os procedimentos emergentes, os dados coletados no ambiente da pesquisa e a análise dos dados indutivamente e as interpretações feitas pelo pesquisador acerca do significado dos dados.

A Fundamentação Teórica da pesquisa, foi construída tendo como principais referenciais: i. o papel de Otlet no que diz respeito à caracterização do Museu como Centro de Informação e dos objetos da coleção como Documento; ii. O objeto enquanto documento; iii. a Documentação em Museus, incluindo seu contexto internacional e nacional, o ciclo documentário e os produtos; iv. o papel de Susan Pearce no que diz respeito à análise de objetos de coleção; e v. os estudos de cultura material, além de identificar o papel dos museus de ciência e tecnologia e apresentar o Museu Correios e a história da telegrafia.

Para a construção desse referencial teórico foram levantados os seguintes documentos:

- Legislação e documentos normativos produzidos por Instituições Nacionais, como Instituto do Patrimônio Histórico e Artístico Nacional (IPHAN) e Internacionais, como a United Nations Educational, Scientific and Cultural Organization (UNESCO).

- Documentos de instituições internacionais e nacionais - como Códigos de Conduta Profissional - bem como de Órgãos e Comitês relacionados à pesquisa como o Comitê Internacional para Documentação (CIDOC) do Conselho Internacional de Museus (ICOM);

- Manuais de Documentação para Acervos Museológicos desenvolvidos por órgãos normativos como o Comitê Internacional para Documentação (CIDOC), o Collections Link, antiga Museum Documentation Association (MDA); o Museum Association (MA); o Société des musées du Québec (SMQ); o Instituto dos Museus e da Conservação (ICM); do Ministère de la Culture et de la Communication da França; bem como de museus de ciência e 
tecnologia nacionais e internacionais como o Museu de Astronomia e Ciências Afins (MAST).

- Artigos acadêmicos da área da Ciência da Informação, Documentação, Gestão da Informação e do Conhecimento, Interdisciplinaridade na Ciência da Informação, Museologia, Antropologia, Etnografia e História.

- Textos desenvolvidos no âmbito dos Estudos de Cultura Material, principalmente no que tange à metodologia de análise de objetos e a aplicação desses métodos em contexto museológico, em especial o trabalho de Susan Pearce.

- Tesauros, glossários, dicionários técnicos de áreas específicas (principalmente Ciência da Informação e Museologia);

Além de seu propósito descritivo e de sua abordagem qualitativa, a pesquisa aqui desenvolvida apresenta natureza aplicada, tendo como finalidade gerar produtos - método de análise e representação da informação de coleções telegráficas - e melhorar processos - documentação em museus. Ou seja, busca gerar conhecimentos para aplicação prática e imediata, focando na solução dos problemas que originaram o estudo. Para corroborar com essa afirmativa, Sekaran afirma que as pesquisas aplicadas são pesquisa “(...) com intenção de aplicação dos resultados para solucionar problemas específicos recorrentemente vivenciados em uma organização". (SEKARAN, 2003, p.8, tradução nossa) ${ }^{68}$

\subsection{Aspectos Práticos}

A primeira fase da pesquisa consistiu em uma análise do atual sistema de documentação do Museu Correios. Esse estudo teve por finalidade a identificação de aspectos desse sistema que não estão de acordo com as normas estabelecidas por órgãos que se debruçam sobre a temática, incluindo como está sendo realizado, atualmente, o tratamento informacional da coleção telegráfica, no que tange à análise e representação da informação, levando a uma documentação frágil dessa

\footnotetext{
68 [...] with the intention of applying the results of the findings to solve specific problems currently being experienced in the organization is called.
} 
faceta do acervo. De posse desses dados, foi possível partir para a segunda fase da pesquisa.

$\mathrm{Na}$ segunda fase, momento em que serão analisados os métodos de cultura material para alcançar o objetivo proposto no projeto, será adotado a pesquisa documentária. Essa técnica, que de acordo com Ahmed é muitas vezes ignorada pelos pesquisadores, se refere à análise de documentos que "[...] contém informações sobre o fenômeno que se deseja estudar". (AHMED, 2010, p.2, tradução nossa) ${ }^{69}$

Ahmed defende que esse método de pesquisa é usado para investigar e categorizar fontes físicas, como documentos registrados - escritos. No que diz respeito a esses documentos o autor defende que - "[...] documentos não se mantém sozinhos" (AHMED, 2010, p.2, tradução nossa) ${ }^{70}$ - ou seja, para serem usados como fontes de dados para pesquisas, os documentos devem ser situados em modelos de referências teóricas.

A técnica de coleta dos dados incluiu, além da revisão sistemática de literatura já mencionada anteriormente, o levantamento e análise descritiva dos métodos de cultura material, a partir de parâmetros pré-estabelecidos, a saber:

Quadro 7 - Parâmetros para Análise dos Estudos de Cultura Material

\begin{tabular}{|l|l|}
\hline \multicolumn{1}{|c|}{ PARÂmetro } & \multicolumn{1}{c|}{ Dados Coletados } \\
\hline Origem disciplinar & $\begin{array}{l}\text { Qual a área do conhecimento em que o autor do modelo } \\
\text { trabalhava ou em qual tipo de objeto pretendia aplicar o } \\
\text { estudo. }\end{array}$ \\
\hline Contexto & $\begin{array}{l}\text { O modelo foi desenvolvido em que contexto: se acadêmico, } \\
\text { se em contexto museológico, em seminários ou congressos, } \\
\text { se esse contexto influenciou no desenvolvimento do modelo, } \\
\text { ou outro aspecto do ambiente de criação do método. }\end{array}$ \\
\hline
\end{tabular}

(continua...)

\footnotetext{
$69[\ldots]$ contains information about phenomenon we wish to study.

$70[\ldots]$ documents do not stand alone.
} 
(continuação do quadro 07)

\begin{tabular}{|c|c|}
\hline $\begin{array}{l}\text { Aplicação em } \\
\text { âmbito } \\
\text { museológico }\end{array}$ & $\begin{array}{l}\text { Buscou-se verificar se em algum momento do texto o autor } \\
\text { cita a aplicação em contexto museológico. }\end{array}$ \\
\hline $\begin{array}{l}\text { Metodologia } \\
\text { (aspectos teóricos) }\end{array}$ & $\begin{array}{l}\text { Esse parâmetro é de análise da teoria a ser aplicada no } \\
\text { estudo do objeto. Como é construído o modelo e se o estudo } \\
\text { proposto está pautado na observação (questão da } \\
\text { subjetividade }{ }^{71} \text { ) ou da análise de dados objetivos. Inclui, } \\
\text { também, previsão de atuação de outros profissionais e uso } \\
\text { de outros documentos (como, por exemplo, arquivísticos). }\end{array}$ \\
\hline $\begin{array}{l}\text { Metodologia } \\
\text { (aspectos práticos) }\end{array}$ & $\begin{array}{l}\text { Diferentemente do aspecto teórico, aqui se analisa como se } \\
\text { dá o estudo na prática. Quais as ações previstas para e com } \\
\text { o objeto. É análise do próprio desenho da pesquisa prevista } \\
\text { no Método. }\end{array}$ \\
\hline $\begin{array}{l}\text { Níveis de } \\
\text { informação } \\
\text { analisados }\end{array}$ & $\begin{array}{l}\text { Tendo como parâmetro para comparação os conceitos de } \\
\text { informações intrínsecas e informações extrínsecas } \\
\text { desenvolvidos por Peter van Mensch, no âmbito da } \\
\text { Documentação em Museus, foco de aplicação do modelos de } \\
\text { estudo de objeto. }\end{array}$ \\
\hline Produtos & $\begin{array}{l}\text { Verificou-se se o autor propôs a criação de algum } \\
\text { documento, dossiê, ou até mesmo formulário catalográficos. }\end{array}$ \\
\hline
\end{tabular}

A seleção dos documentos analisados não foi realizada de forma aleatória. Segundo Flick (2009), qualquer tipo de documento foi produzido por alguém (ou alguma instituição) visando algum objetivo e a algum tipo de uso. Assim, o autor indica o questionamento acerca do quem produziu o documento usado na pesquisa, para quem e com qual objetivo, além de suas intenções e o provimento do documento. Logo, todo documento deve ser selecionado seguindo um certo controle de qualidade - padrões definidos de autenticidade, credibilidade, representatividade e significado (FLICK, 2009; AHMED, 2010; MOGALAKWE, 2006).

\footnotetext{
${ }^{71}$ A questão da subjetividade na presente dissertação se justifica na necessidade de informações certificadas no que tange à Documentação dos objetos musealizados, para posterior comunicação e disseminação.
} 
Nesse ponto faz-se imperativo justificar o recorte nos métodos de análise de cultura material que foram estudados. A historiadora inglesa Susan Pearce é uma pesquisadora referência na área da Museologia, principalmente no que se refere ao estudo do colecionismo e dos objetos que compõem os acervos museológicos. Em seus estudos ela identifica aspectos teóricos do processo de atribuição de valor e musealização, bem como o estudo dos objetos e a sua "vida social". Para esse estudo do objeto ela identificou métodos desenvolvidos por profissionais de diversas áreas das Ciencias Humanas e Sociais - como a Arqueologia, a Etnografia e a História - que são passíveis de aplicação em instituições museológicas. Uma vez que a produção acadêmica de Susan Pearce é tomada como referência nos estudos de objeto no âmbito da Museologia ${ }^{72}$, para a presente pesquisa optou-se por analisar os métodos já identificados pela historiadora, tendo como parâmetro o papel desempenhado pela pesquisadora na temática abordada.

A análise desses dados será realizada de acordo com o modelo de análise de conteúdo indicada por Ahmed. O esquema a seguir, adaptado de Miles and Huberman, representa o trabalho de análise aqui proposto:

Figura 32 - Método de Análise de Dados

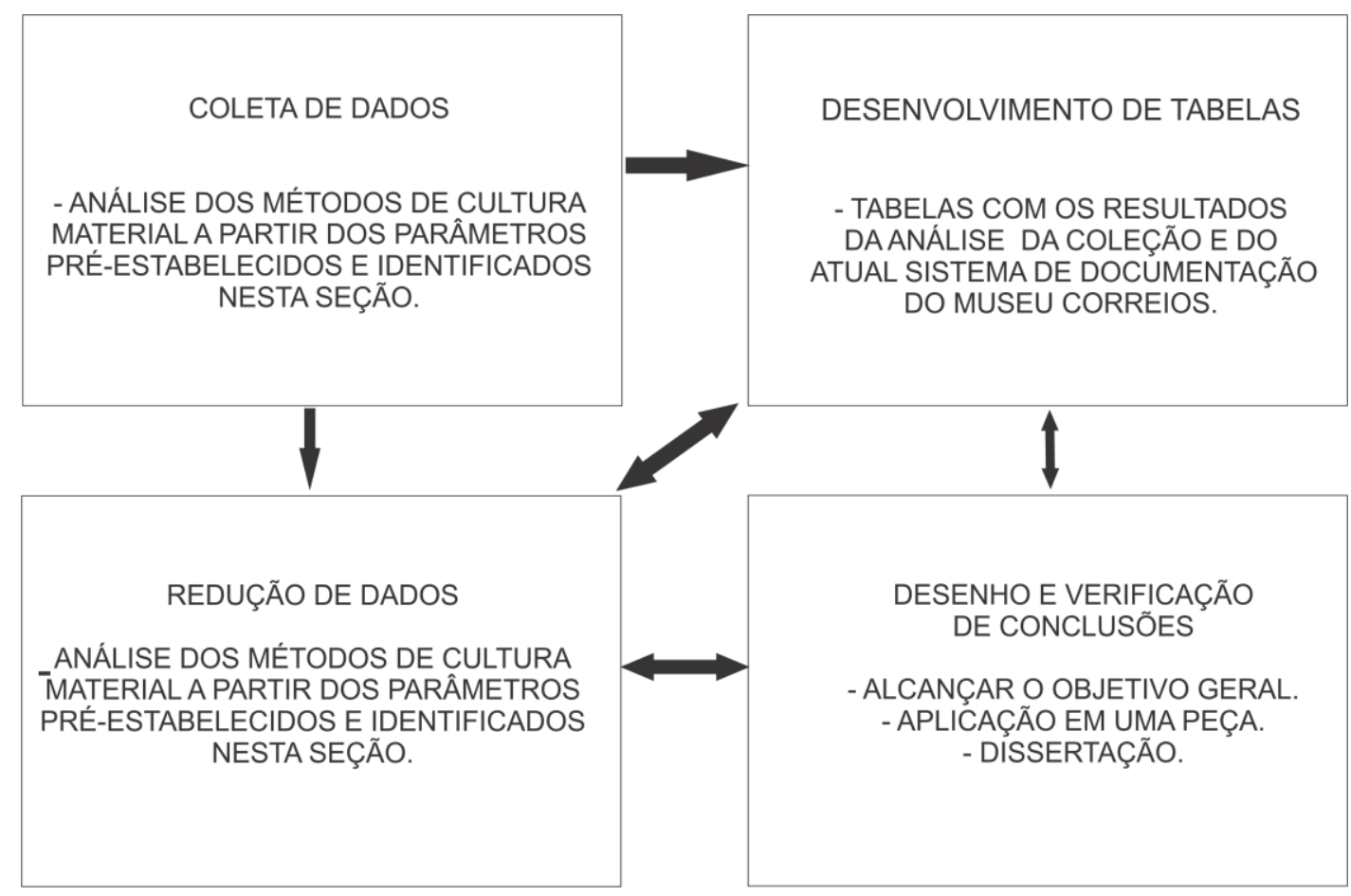

Fonte: adaptado de Miles and Huberman apud Ahmed, 2010

${ }^{72}$ Como as pesquisas desenvolvidas por Marcus Granato e Maria Lucia Loureiro. 
Para o autor, a análise dos dados "[...] é a busca para a explicação e o entendimento no qual conceitos e teoria são passíveis de avanços, considerações e desenvolvimento" (2010, p. 5-6, tradução nossa) ${ }^{73}$, e ainda que é a forma de trazer ordem, estrutura, e significado à massa de dados coletados.

Os dados coletados foram, então, reduzidos e dispostos em tabelas a fim de facilitar a visualização das informações e alcaçar os objetivos propostos. De acordo com Ahmed (2010), em abordagens qualitativas a estrutura usada em uma pesquisa deve ser derivada dos dados, o que significa analisar sistematicamente a fim de definir os conceitos, termos e definições que nortearão os resultados do estudo.

A pesquisa visou, com análise aqui descrita, a indicação de um método apropriado para o tratamento informacional da coleção telegráfica do Museu Correios.

73 [...] is about the search for explanation and understanding, in the course of which concepts and theories are likely to be advanced, considered and developed. 


\section{Resultados e Análise}

\subsection{Análise do Sistema de Documentação da Coleção Telegráfica do Museu}

\section{Correios}

A pesquisa "Tratamento Informacional da Coleção Telegráfica do Museu Correios: análise sob a perspectiva científica, tecnológica e de cultura material" foi dividida em duas partes, conforme visto na Metodologia.

$\mathrm{Na}$ primeira fase, foi analisado o sistema de documentação do Museu Correios, buscando identificar pontos negativos e positivos nas práticas documentais, em especial na análise e representação da informação da coleção telegráfica.

Vale ressaltar que, para essa pesquisa, um sistema de documentação é um conjunto de elementos que permitem que a informação museológica seja "[...] estruturada, controlada semanticamente e legível por uma máquina" (BACA et. al, 2008, p. 107, tradução nossa $)^{74}$. Assim, falamos de um sistema que usa vocabulário, gramática própria, organização, estrutura de dados para representação da informação e posterior recuperação.

A primeira fase da pesquisa, em especial o foco acima descrito, teve como justificativa a necessidade e a importância da normalização das atividades de Documentação em Museus:

Não se pense, no entanto, que basta colocar um computador e respectivo software para criação de bases de dados num museu para que o trabalho de documentação das colecções possa ser feito com qualidade. Não são as ferramentas tecnológicas que fazem um excelente trabalho. Pelo contrário, no nosso trabalho neste domínio, verificámos que, quando não utilizadas convenientemente, são estas ferramentas as causadoras das maiores dificuldades. Frequentemente somos confrontados com trabalhos de documentação de colecções que, feitos sem qualquer apoio informático, são mais válidos e eficientes do que alguns com suporte informático, porém incomparavelmente lentos face às necessidades actuais e rapidamente obsoletos do ponto de vista tecnológico. No entanto, reflectindo com seriedade, qual é a mais valia da rapidez, ou da evolução tecnológica per si, quando a resposta de um sistema não é satisfatória ou pode ser mesmo errónea?

As ferramentas utilizadas não dispensam, em nenhuma área de atividade, o planeamento, estratégia e conhecimento sobre o

\footnotetext{
${ }^{74}[\ldots]$ structured, semantically controlled and machine readable.
} 
assunto em questão. Assim, num museu a documentação das colecções deve ter em conta alguns aspectos essenciais como o método, os meios e a linguagem utilizados que têm por base um conceito comum: a normalização. (MATOS, 2011, p. 9, grifo nosso)

\subsubsection{Parâmetros para Análise}

O Comitê Internacional para Documentação (CIDOC) do Conselho Internacional de Museus (ICOM) é um órgão criado para a elaboração de Normas e Procedimentos referentes às atividades da Documentação em Museus.

Em 1993 foi publicado, pelo CIDOC, o documento Developments in museum and cultural heritage informantion standards. Atualizado em 1995, esse documento tinha como foco o desenvolvimento de padrões (standards) para documentação em museus, explicitando a importância, os formatos e os desafios que o grupo responsável por essas normas enfrentariam para o estabelecimento de diretrizes para o trabalho nessas instituições.

Nesse documento, também, foram divididas em quatro grupos principais as demandas que os museus tinham em relação aos padrões de informação, a saber:

- Padrões de Sistemas de Informação - referente aos componentes funcionais de informação do sistema como um todo;

- Padrões de Dados - referente à estrutura, conteúdo e valores da informação das coleções;

- Padrões de Procedimentos - referente ao escopo dos procedimentos documentais necessário efetivamente à gestão operacional.

- Padrões de Intercâmbio de Informações - referente ao quadro técnico para o intercâmbio de informações. (CIDOC, 1995b, n/p)

Para a presente pesquisa, cujo foco é a análise e representação da informação das coleções de ciência e tecnologia, em especial à coleção telegráfica do Museu Correios (MC), o ambiente de avaliação do sistema de documentação do MC foi o segundo conjunto de padrões - Padrões de Dados - cujo conteúdo e explicação de como foi feita a análise se encontra no quadro a seguir: 


\section{Quadro 8 - Parâmetros para a análise do sistema de documentação do Museu Correios -} Padrões de Dados

\begin{tabular}{|c|c|c|}
\hline $\begin{array}{l}\text { OBJETO DE } \\
\text { ANÁLISE }\end{array}$ & DEFINIÇÃO & PARÂMETROS \\
\hline $\begin{array}{l}\text { Estrutura dos } \\
\text { Dados } \\
\text { (data } \\
\text { structure) }\end{array}$ & $\begin{array}{l}\text { Os elementos - categorias de } \\
\text { informação (metadados) - que } \\
\text { compõem um esquema - a } \\
\text { ficha catalográfica. }\end{array}$ & $\begin{array}{l}\text { Análise dos campos que } \\
\text { compõem as fichas utilizadas no } \\
\text { Museu Correios, tendo como } \\
\text { parâmetro, o documento } \\
\text { desenvolvido pelo CIDOC e a } \\
\text { legislação nacional (IBRAM). }\end{array}$ \\
\hline $\begin{array}{l}\text { Procedimento } \\
\text { (data contents) }\end{array}$ & $\begin{array}{l}\text { As regras ou padrões para o } \\
\text { preenchimento dos campos de } \\
\text { informação - os manuais de } \\
\text { catalogação. }\end{array}$ & $\begin{array}{l}\text { Análise dos procedimentos de } \\
\text { representação da informação } \\
\text { (incluindo } \text { análise da } \\
\text { informação), tendo como } \\
\text { parâmetro, o SPECTRUM. }\end{array}$ \\
\hline $\begin{array}{l}\text { Terminologia } \\
\text { (data value) }\end{array}$ & $\begin{array}{l}\text { O dado que é inserido nos } \\
\text { campos de informação - } \\
\text { terminologia. }\end{array}$ & $\begin{array}{l}\text { Análise dos Vocabulários } \\
\text { Controlados utilizados na } \\
\text { representação da informação. }\end{array}$ \\
\hline
\end{tabular}

Fonte: adaptado de CIDOC, 1995b

A importância para se estudar os padrões é que, segundo o CIDOC, esse tipo de normativa dispõe as "regras para estruturar a informação, de forma que os dados inseridos no sistema possam ser lidos, classificados, indexados, recuperados e comunicados entre sistemas de forma confiável" (CIDOC, 1995b, n/p, tradução nossa $)^{75}$.

No caso da presente pesquisa, fez-se imperativa a análise dos padrões de dados utilizados nos processos documentais no Museu Correios uma vez que é com esses dados que a informação museológica - ou a informação contida nos objetos é analisada e representada para posterior recuperação e uso em pesquisas, exposições, publicações, ações educativas, segurança, gestão das coleções e para uso pelo público.

\footnotetext{
75 Standards give the rules for structuring information, so that the data entered into a system can be reliably read, sorted, indexed, retrieved, and communicated between systems.
} 
Dessa forma, foram tomados como base de referência quatro projetos desenvolvidos em âmbito internacional (ICOM, CIDOC, Fundação J.Paul Getty, UNESCO e a Collections Trust) e a legislação nacional (IBRAM), que se debruçaram sobre a temática dos campos de informação que devem conter em uma ficha catalográfica de modo que a documentação dos objetos se faça de forma completa e estruturada.

Quadro 9 - Estrutura dos Dados - Parâmetros de Análise

\begin{tabular}{|l|l|}
\hline \multicolumn{1}{|c|}{ INSTITUIÇÃo } & \multicolumn{1}{c|}{ ProjeTo } \\
\hline ICOM, AFRICOM & AFRICOM Handbook od Standards \\
\hline ICOM, CIDOC & $\begin{array}{l}\text { International Guideline for Museum } \\
\text { Objects Information }\end{array}$ \\
\hline ICOM, Fundação J.Paul Getty, UNESCO & Object-ID \\
\hline Collections Trust & SPECTRUM \\
\hline IBRAM & $\begin{array}{l}\text { Resolução Normativa no 02, de 02 de } \\
\text { agosto de 2014 }\end{array}$ \\
\hline
\end{tabular}

O AFRICOM foi um projeto desenvolvido pelo ICOM e pelo, hoje, Coselho Africano de Museus (AFRICOM) tendo como objetivo a elaboração de normas para catalogação dos objetos de História Natural e Humanidades (Arqueologia e Antropologia) que compõem os museus africanos. O projeto é composto por cinquenta campos de informação, divididos em quatro grupos, a saber: gestão do objeto, descrição do objeto, histórico do objeto e documentação do objeto.

O CIDOC, comitê específico para documentação do ICOM, é o responsável pelo documento International Guideline for Museum Objects Information (IGMO) ${ }^{76}$, já descrito nessa dissertação, no ponto 2.2 da Fundamentação Teórica ${ }^{77}$.

\footnotetext{
76 Sigla não-oficial, utilizada nesse trabalho

77 Ver página 43.
} 
Assim como o IGMO, o Object-ID, projeto desenvolvido pela Fundação J. Paul Getty, em parceria com a UNESCO e com o ICOM, também já foi alvo de análise nessa dissertação. ${ }^{78}$

A Collections Trust é responsável pelo projeto SPECTRUM, herdado da Museum Documentation Association (MDA) ${ }^{79}$. O SPECTRUM, cuja primeira edição é de 1994, foi desenvolvido, primeiramente, como um suporte para o museus britânicos no que tange à definição de boas práticas em gestão de coleções musealizadas. O documento apresenta detalhes e definições de ações que incluem o ciclo do objeto no museu, desde o momento de sua entrada na instituição, até seu descarte, passando por processos como registro, catalogação ${ }^{80}$, empréstimo e conservação. O projeto SPECTRUM está sendo posto em prática em mais de 100 países ao redor do mundo, incluindo o Brasil, que traduziu o documento para o português em 2014, sob a responsabilidade da Pinacoteca do Estado de São Paulo, em parceria com o Museu da Imigração.

Cabe ressaltar que tanto do SPECTRUM quanto do IGMO foram analisados os Grupos de Informação. Ambos os padrões apresentam mais de 80 campos de informação divididos nesses Grupos específicos.

E, por último, em âmbito nacional, foram usado como parâmetro a Resolução nº 02, de 02 de agosto de 2014, que dispõe sobre o Inventário Nacional de Bens Culturais Musealizados (INBCM), já apresentado nessa dissertação. ${ }^{81}$

\subsubsection{Estrutura de Dados (Data Structure)}

O primeiro dos parâmetros analisados diz respeito à estrutura dos dados (data structure) que, em linhas gerais, se configura por campos de informação, que compõem a ficha catalográfica, nos quais os dados serão inseridos e a informação consistentemente estruturada, daí sua importância.

Andrew Roberts, em texto publicado no livro "Como Gerir um Museu", publicação do ICOM com a UNESCO, elaborou um quadro comparativo a partir das

\footnotetext{
78 Ver página 41.

79 A MDA foi extinta em 2012.

$80 \mathrm{O}$ capítulo referente à Catalogação contém dados para elaboração de fichas catalográficas, usados como parâmetro para análise da estrutura de dados.

81 Ver página 36.
} 
categorias de informação propostos pelos quatro projetos internacionais - aqui adaptado com o contexto nacional - de forma que permite visualização dos dados, ditos mínimos, previstos por esses padrões de documentação:

Quadro 10 - Campos de Informação - Comparação entre Padrões de Documentação

\begin{tabular}{|c|c|c|c|c|c|}
\hline CAMPO DE INFORMAÇÃO & AFRICOM & CIDOC & SPECTRUM & OBJECT ID ${ }^{82}$ & IBRAM \\
\hline Dados da Instituição & $x$ & $x$ & $x$ & $x$ & \\
\hline Número do objeto & $x$ & $x$ & $x$ & $x$ & $x$ \\
\hline Outros números & & & $x$ & & $x$ \\
\hline Método de aquisição & $x$ & $x$ & $x$ & & \\
\hline Data de aquisição & $x$ & $x$ & $x$ & & \\
\hline Fonte de aquisição & $x$ & $x$ & $x$ & & \\
\hline Localização & $x$ & $x$ & $x$ & $x$ & $x$ \\
\hline Localização atual & & $x$ & $x$ & & \\
\hline $\begin{array}{c}\text { Data de localização } \\
\text { atual }\end{array}$ & & $x$ & $x$ & & \\
\hline $\begin{array}{l}\text { Intervenção - } \\
\text { conservação }\end{array}$ & & & $x$ & & \\
\hline Data da intervenção & & & $x$ & & \\
\hline $\begin{array}{l}\text { Respónsável pela } \\
\text { intervenção }\end{array}$ & & & $x$ & & \\
\hline $\begin{array}{l}\text { Número de referência da } \\
\text { intervenção }\end{array}$ & & & $x$ & & \\
\hline
\end{tabular}

(continua...)

82 Está incluso nos metadados do Object ID os campos chamados no projeto de Informações Complementares. 
(continuação do quadro 10)

\begin{tabular}{|c|c|c|c|c|c|}
\hline Método de descarte & & $x$ & $x$ & & \\
\hline Data de descarte & & $x$ & $x$ & & \\
\hline Destinátrio - Descarte & & $x$ & $x$ & & \\
\hline Descrição física & $x$ & $x$ & $x$ & $x$ & $x$ \\
\hline $\begin{array}{c}\text { Características - } \\
\text { Distinção }\end{array}$ & $x$ & & $x$ & $x$ & \\
\hline Imagem & $x$ & $x$ & $x$ & $x$ & \\
\hline Nome do objeto & $x$ & $x$ & $x$ & $x$ & $x$ \\
\hline Nome local & $x$ & & & & \\
\hline Título & $x$ & $x$ & $x$ & $x$ & $x$ \\
\hline Classificação & $x$ & $x$ & $x$ & & $x$ \\
\hline $\begin{array}{c}\text { Categoria por forma ou } \\
\text { função }\end{array}$ & $x$ & & & $x$ & $x$ \\
\hline Categoria por técnica & $x$ & & & & \\
\hline Material & $x$ & $x$ & $x$ & $x$ & $x$ \\
\hline Técnica & $x$ & $x$ & $x$ & $x$ & $x$ \\
\hline Dimensões & $x$ & $x$ & $x$ & $x$ & $x$ \\
\hline Formato do espécime & $x$ & & $x$ & & \\
\hline Parte do corpo & $x$ & & & & \\
\hline Sexo & $x$ & & & & \\
\hline Idade ou época & $x$ & & & & \\
\hline
\end{tabular}


(continuação do quadro 10)

\begin{tabular}{|c|c|c|c|c|c|}
\hline Tema/conteúdo/assunto & & $x$ & $x$ & $x$ & \\
\hline $\begin{array}{c}\text { Inscrições - Tipo de } \\
\text { marca }\end{array}$ & & $x$ & $x$ & $x$ & \\
\hline Inscrição - Método & & $x$ & $x$ & & \\
\hline Inscrição - Localização & & $x$ & $x$ & & \\
\hline Inscrição - Transcrição & & $x$ & $x$ & & \\
\hline Inscrição - Tradução & & $x$ & $x$ & & \\
\hline Inscrição - Descrição & $x$ & $x$ & $x$ & $x$ & \\
\hline $\begin{array}{l}\text { Avaliação de } \\
\text { Conservação }\end{array}$ & $x$ & $x$ & $x$ & $x$ & \\
\hline $\begin{array}{c}\text { Data de Avalição de } \\
\text { Conservação }\end{array}$ & & $x$ & $x$ & & \\
\hline Comentários históricos & $x$ & & $x$ & & \\
\hline Frabricante/autor & $x$ & $x$ & $x$ & $x$ & $x$ \\
\hline Local de produção & $x$ & $x$ & $x$ & $x$ & $x$ \\
\hline Função de produção & & $x$ & $x$ & & \\
\hline Período de produção & $x$ & $x$ & $x$ & $x$ & $x$ \\
\hline Usuário & $x$ & $x$ & $x$ & & \\
\hline Local de uso & $x$ & $x$ & $x$ & & \\
\hline Período de uso & $x$ & $x$ & $x$ & & \\
\hline Informações associadas & & $x$ & $x$ & & \\
\hline
\end{tabular}

(continua...) 
(continuação do quadro 10)

\begin{tabular}{|c|c|c|c|c|c|}
\hline Local de coleta & $x$ & $x$ & $x$ & & \\
\hline $\begin{array}{l}\text { Referência/nome do } \\
\text { local }\end{array}$ & $x$ & & $x$ & & \\
\hline Coordenadas do local & $x$ & & & & \\
\hline Tipo de local & $x$ & & $x$ & & \\
\hline $\begin{array}{c}\text { Datação - Período } \\
\text { Geológico }\end{array}$ & $x$ & & & & \\
\hline Coletor & $x$ & $x$ & $x$ & & \\
\hline Data de coleta & $x$ & $x$ & $x$ & $x$ & \\
\hline Método de coleta & $x$ & $x$ & $x$ & $x$ & \\
\hline Número de coleta & $x$ & & $x$ & & \\
\hline Referências & $x$ & $x$ & $x$ & $x$ & $x$ \\
\hline $\begin{array}{l}\text { Direitos autorais ou de } \\
\text { reproduçao }\end{array}$ & & $x$ & $x$ & & $x$ \\
\hline
\end{tabular}

Fonte: atualizado e adaptado de ROBERTS, 2004.

Os documentos acima comparados, conforme explicado, são os principais projetos desenvolvidos por órgãos internacionais e nacionais de documentação. Vale ressaltar que todos os projetos que compõem a tabela acima se apresentam como base para a elaboração de fichas, levando em consideração as diversas naturezas de coleções, afirmando que não são restritivos e exaustivos, cabendo à instituição selecionar os campos que correspondem ao núcleo de seus formulário, podendo acrescentar categorias de informação específicas à temática de seu acervo.

Dessa forma, tendo como base esses documentos normativos, e suas respectivas categorias de informação previstas como essenciais num formulário, foi 
realizada análise da ficha de catalogação do Museu Correios de forma a verificar sua adequação à realidade normativa da área.

A ficha de catalogação do Museu Correios foi desenvolvida, primeiramente, na década de 1970 (ver Anexo I), quando do início da catalogação do acervo museológico dos Correios, por uma equipe que continha em seu corpo profissional, uma museóloga.

Posteriormente, essa ficha foi adaptada à atual realidade da instituição (ver Anexo II). Dessa forma, o documento, mesmo que apresente alguns campos identificados no quadro 10, não está de acordo com as normas estabelecidas pelo órgãos reguladores da temática em tela.

Após a análise da estrutura dos dados, a pesquisa verificou a entrada desses dados a partir de duas questões: o formato dos dados (procedimento) e o conteúdo (terminologia).

\subsubsection{Procedimentos (Data Contents)}

A catalogação, conforme verificado, é um conjunto de ativididades que inclui o desenvolvimento de formulário para cada um dos objetos que compõem as coleções. Nesse formulário, chamado ficha catalográfica, e cuja temática já foi tratada no ponto anterior, são representadas as informações dos objetos por meio da escrita. (FERREZ, 1994)

Sendo assim, o objeto é analisado e seus dados recuperados para posterior inclusão nos campos de informação (data structure) que compõem a ficha catalográfica. Essa análise da informação - ou análise do conteúdo dos documentos - e a representação na ficha de catalogação é o que configura o parâmetro aqui analisado: Procedimentos (data contents).

Os procedimentos de análise e representação da informação devem ser desenvolvidos a partir de ações pré-estabelecidas e parametrizadas pelos profissionais envolvidos nas atividades de gestão das coleções. Nessas regras processuais inclui-se metodologias de análise de objetos - foco dessa pesquisa -, regras de formato e convenções de entrada de dados nos formulários. 
No entanto, mesmo que sejam procedimentos estabelecidos pelo próprio corpo profissional das instituições museológicas, é recomendável que essas diretrizes devam estar de acordo com as descrições nacionais e internacionais desenvolvidas por órgãos normativos, como o CIDOC.

Em nível internacional o IGMO (CIDOC/ICOM) e o Spectrum (Collections Trust) são os documentos-base para a elaboração de normativas para a Documentação em Museus. Em nível nacional, o IBRAM é o órgão máximo para elaboração de documentos orientacionais para os museus - aqui representados pela Resolução Normativa no 02.

Nesses documentos são estabelecidos as regras e procedimento, e padrões de inclusão de dados nos formulários, também estabelecidos nesses projetos e já analisados no ponto anterior. No entanto, no que tange à análise do conteúdo informacional dos objetos não há nenhuma orientação oficial para esse procedimento, cabendo a cada instituição a delimitação de suas diretrizes para estudo do objeto.

A análise de conteúdo é imperativa para a catalogação, uma vez que é a partir dessa ação que são recuperados os dados necessários para o preenchimento dos formulários. Cabe ressaltar, também, que é a partir dessa análise que se identificam os valores atribuídos ao objeto, incluindo sua patrimonialização e musealização.

As regras de formato do conteúdo do objeto definem a estrutura do registro, como por exemplo como devem ser incluídas as datas, nomes e como proceder no caso de falta de certificação de alguma informação. Esse padrão tem como principal objetivo a uniformidade do registro e auxiliar na recuperação eficiente da informação por parte dos usuários. (CIDOC, 1995a)

O Museu Correios não possui, atualmente, normativa para análise de conteúdo dos documentos e de inclusão dos dados nas fichas catalográficas. Dessa forma, o trabalho de análise de conteúdo e representação da informação na instituição não é realizada a partir de diretrizes e com controle de inclusão de dados, pré-requisito para uma documentação efetiva e consistente. 


\subsubsection{Terminologia (Data Value)}

A questão da Terminologia (data value) utilizada em sistemas de documentação em museus vem responder a demanda de eliminação de ruídos nos momentos de representação, e de recuperação e disseminação da informação. Sendo assim, a ánalise da terminologia em sistemas documentais é complementar à análise dos procedimentos de documentação.

O controle terminológico é utilizado no estabelecimento de termos apropriados para representação da informação nas categorias do formulário linguagem documentária. Esse controle também responde a uma demanda do profissional responsável pela documentação no desenvolvimento de registros consistentes, e do usuário na recuperação desses dados.

O desenvolvimento de terminologias adequadas inclui a identificação de termos e definições, classificação e categorização desses conceitos, decisão quanto à presença de termos preferenciais e gerais, e, principalmente, a identificação de relações entre os termos - questão da hierarquização.

Atualmente, no campo dos museus, instituições de pesquisa como a J. Paul Getty Institute, o Museu Histórico Nacional e o Museu de Astronomia e Ciências Afins, desenvolvem vocabulários controlados que respondem às demandas de instituições diversas cujas coleções são de naturezas completamente diferentes.

A J. Paul Getty Institute, em especial o Getty Research Institute, é uma das instituições pioneiras no desenvovlimento de terminologias para classificação de objetos musealizados. Seus projetos envolvem o estabelecimento de tesauros e vocabulários controlados para as áreas das Artes, Arquitetura, Artes Decorativas, materiais arquivísticos, para conservação e material bibliográfico.

Atualmente o Getty Resarch Institute já desenvolveu, mesmo que em contínuo crescimento, o The Art \& Architetures Thesaurus (AAT), o The Getty Thesaurus of Geographic Names (TGN), a The Cultural Objects Name Authority (CONA) e a The Union List of Artists Names (ULAN).

Esse conjunto de terminologias desenvolvidas pela Getty respondem à uma gama variada de demandas documentais das instituições museológicas. A lista de nomes de objetos culturais, por exemplo, apresenta metodologias e listas de termos 
para diversas categorias de informação presentes em fichas catalográficas, como material e técnica.

Em âmbito nacional, dois projetos são de relevância para as atividades dos museus: o Thesaurus para Acervos Museológicos, da antiga Fundação Nacional Pró-Memória em parceria com o Museu Histórico Nacional, e o Thesaurus de Acervos Científcos, do Museu de Astronomia e Ciências Afins, em parceria com instituições científicas de Portugal.

O Thesaurus para Acervos Museológico, publicado em 1987, é produto de um projeto encabeçado pela museóloga Maria Helena S. Bianchini e pela documentalista Helena Dodd Ferrez. Tendo como parâmetro classificatório a função do objeto antes de sua musealização, o Thesaurus foi desenvolvido para responder a uma demanda gerencial do Museu Histórico Nacional, maior instituição museológica do Brasil, cujo acervo é composto das mais variadas categorias de objetos, e cujo espaço serviu de ambiente de teste para as autoras.

Apesar de amplitude do Thesaurus, o projeto necessita de atualização, já não compreendendo toda a gama de objetos que fazem parte das coleções musealizadas. No entanto, conforme as orientações de Bianchini e Ferrez, é possível utilizar o material, mesmo que não contendo o termo classificatório no documento, bastando sua categorização a partir de sua função original.

A partir da demanda da área museológica de língua portuguesa de uma ferramenta para o controle terminológico e disseminação efetiva da informação em museus de C\&T, o MAST, em parceria com outros museus da comunidade lusófona, em especial Brasil e Portugal, e com a prof. Rosali Fernandez de Souza, do IBICT, desenvolveu o Thesaurus de Acervos Científicos ${ }^{83}$. Iniciado em 2006, o documento foi lançado durante um congresso em Manchester (Inglaterra), em 2013.

Encabeçado por Marcus Granato ${ }^{84}$ o projeto teve por objetivo 0 desenvolvimento de um vocabulário controlado para acervos científicos, que sirva como ferramenta para o trabalho dos documentalistas, responsáveis por coleções

\footnotetext{
${ }^{83}$ Disponível em: http://chcul.fc.ul.pt/thesaurus/

${ }^{84}$ Marcus Granato é engenheiro e coordenada o setor de Museologia no MAST. A principal área de seu interesse é a Museologia e Patrimônio, cujas pesquisas se concentram nos seguintes temas: patrimônio científico, conservação de objetos metálicos e divulgação da ciência.
} 
científicas musealizadas, cujo objetivo seja a efetiva documentação desses exemplares. Composto por uma estrutura de termos de topo, o thesaurus apresenta classificação por áreas do conhecimento e lista com cerca de 3000 termos.

Essas ferramentas terminológicas, quando postas em prática, possibilitam efetiva representação e disseminação da informação. Assim, ao lado dos Procedimentos (Data content), as questões referentes à Terminologia (Data value) fazem-se imperativas em um sistema de documentação em museus.

O sistema do Museu Correios, no que tange ao controle terminológico na representação da informação de suas coleções, utiliza o Thesaurus para Acervos Museológicos - principalmente no que diz respeito à classificação dos objetos. No entanto, outros campos de informação não apresentam listas de termos controlados, o que dificulta a padronização na inserção dos dados nas fichas catalográficas.

Em especial à coleção telegráfica, o Thesaurus do MHN não possui terminologia específica para essa tipologia de acervo. No entanto, é possível encontrar os termos e conceitos de C\&T no vocabulário desenvolvido pelo MAST, fazendo-se, então, imperativa sua utilização na documentação das peças da coleção telegráfica. 


\subsection{Descrição dos Estudos de Cultura Material}

Após a análise do Sistema de Documentação do Museu Correios - primeira fase - e a identificação das dificuldades e fraquezas desses conjunto de elementos, partiu-se então para a segunda fase da pesquisa - análise dos Estudos de Cultura Material.

Os Estudos de Cultura Material, como visto na Fundamentação Teórica, são metodologias desenvolvidas por profissionais de diversas áreas do conhecimento, como a História, a Antropologia e a Arqueologia, visando criar ferramentas para a análise de objetos - Cultura Material.

A pesquisa "Tratamento Informacional da Coleção Telegráfica do Museu Correios: análise sob a perspectiva científica, tecnológica e de cultura material" analisou algumas dessas metodologias visando identificar qual desses estudos poderia ser aplicado no Museu Correios para auxiliar na Gestão das Coleções, em especial na atividade prática da Documentação.

Os modelos levantados e aqui descritos foram identificados por Susan Pearce como passíveis de aplicação em ambiente museológico. Tendo como base a produção científica de Pearce na área da Museologia, a pesquisa se ambientou nos estudos de pesquisadora justificando a escolha dos modelos a serem analisados.

Ainda respondendo aos objetivos, a pesquisa buscou verificar a aplicação desses métodos no âmbido de Museus de Ciência e Tecnologia, uma vez que não foram desenvolvidas ferramentas para auxiliar essa tipologia de museus na gestão de suas coleções.

\subsubsection{O Modelo de Montgomery}

Charles Montgomery foi um dos professores pioneiros no estudo da teoria da cultura material (SCHLERETH, 1981, p. 143). Iniciou sua carreira como antiquário e, posteriormente, entrou para o corpo técnico do Henry Francis Du Pont Winterthur Museum, onde chegou a ocupar o cargo de diretor e pesquisador.

Deu aulas na Winterthur University, no curso de Early American Culture, curso esse concebido por ele e por E. McClung Fleming. 
O artigo escrito por Montgomery, no qual ele explica seu método para análise de objetos, foi, inicialmente, desenvolvido como um exercício para os alunos do curso de Artes Decorativas. Em 1961 o artigo foi reformatado e publicado na American Walpole Society Notebook, sob o título "Some remarks on the practice and science of connoisseurship".

A intenção do autor ao desenvolver seu método era "estudar cada objeto com uma mente investigativa assim como com um olhar investigativo" (SCHLERETH,1981, p. 144). Assim, ele desenvolveu um método dividido em quatorze pontos de análise primária para o estudo de Artes Decorativas. No entanto, segundo Schlereth (1981), essa metodologia é aplicável a qualquer tipologia de acervo, mesmo sendo considerada, pelo próprio Montgomery, como um exercício subjetivo para Artes Aplicadas, com o qual os estudantes poderiam identificar o sucesso da peça enquanto objeto artístico. Apesar de seu foco artístico, o modelo proposto por Montgomery vai além dos aspectos estéticos, porém sem entrar muito nas questões funcionais ou culturais propostas pelos outros autores.

Os quatorze pontos de análise propostos por Montgomery, nas quais é possível identificar a influência da área de atuação do autor, são:

- Aspecto geral - o autor propõe análise superficial e sensorial, com aspectos de natureza subjetiva (opiniões individuais).

- Forma - o segundo ponto inclui análise de concepção, proporção e medidas que, segundo o autor, podem fornecer informações quanto à autenticidade e datação.

- Ornamentos - buscando fugir da subjetividade, o autor indica que para avaliar o aspecto da ornamentação o profissional deve ter noção dos ornamentos utilizados pelas escolas e pelos artistas, entender a atitude do artista diante do ornamento e qual a intenção do artista com aquele ornamento.

- Cor - o autor não busca somente descrição cromática. A análise da cor inclui verificar esmaecimentos e alterações. Segundo Montgomery, assim como a forma, a cor pode fornecer informações importantes para a compreensão da obra como um todo. 
- Análise do Material - Montgomery, nesse passo, apresenta o estudo dos materiais, incluindo as análises laboratoriais, em busca de informações acerca da do artista ou da sociedade que a produziu.

- Técnicas empregadas na manufatura - o trabalho de análise das técnicas inclui a atribuição de valor ao trabalho do artista ou fabricante, as técnicas e as práticas empregadas, o emprego de assinaturas em alguns objetos (exclusividade) e a comunicação com outros objetos, caso faça parte de conjuntos de mesma autoria ou de diferentes autorias). $O$ autor inclui, ainda, o estudo das restaurações que porventura possam ser encontradas.

- Práticas comerciais (de troca) - marcas de manufatura ou aspectos comerciais e legais relacionados ao objeto podem, muitas vezes, segundo o autor, auxiliar em datações ou no entendimento do objeto como um todo.

- Função - o foco no estudo da função é justamente entender o motivo da existência do objeto.

- Estilo - envolve o estudo da forma, ornamentos, cores e técnicas de fabricação e manufatura, e a análise das informações coletadas nos passos anteriores.

- Data - a datação, segundo Montgomery, requer não somente que os dados anteriores sejam considerados, mas também o auxílio de documentos sobre o objeto. Quando possível, atribuir períodos de tempo, tendo como parâmetro assinaturas ou outro tipo de dado fornecido pelo objeto. $O$ autor chama atenção, ainda, para o perigo das informações não confirmadas no momento de atribuição um período de fabricação ou manufatura.

- Atribuição - dividida entre atribuição de autoria e atribuição de estilo. A atribuição de autoria inclui verificação de autenticidade de assinaturas e marcas. No que diz respeito à atribuição de estilo o autor afirma que a maior dificuldade encontrada é quando não se há certeza da autoria, são as cópias, adaptações, falsificações, ou até mesmo autoria de aprendizes.

- Histórico do objeto ou do proprietário - inclui dados de catálogos de antiquários, leilões e exposições que o objeto participou. Essas informações trazem autenticidade e, ao mesmo tempo, dados para uma cronologia do objeto. 
- Estado de conservação - outro ponto da análise de objeto proposta por Montgomery que tem grau elevado de subjetividade. O estado de conservação é atribuição de valor do pesquisador no que diz respeito ao aspecto físico do objeto.

- Apreciação ou avaliação - após o estudo dos treze pontos anteriores, o décimo quarto, e último, ponto de análise é uma visão geral e a atribuição de valor por parte do pesquisador.

\subsubsection{O Modelo de Fleming}

Edward McClung Fleming nasceu na Índia, filho de pais missionários. Aos três anos a família retorna para os Estados Unidos, onde ele se forma na Yale University. Consegue os títulos de mestre (MA) e doutor (PhD) na Columbia University, no programa de American Intellectual and Cultural History.

Em 1955 passa a fazer parte do corpo profissional do Winterthur Museum, em Delaware, onde ocupou o cargo de chefe do setor educativo até o fim de sua carreira profissional. Entre suas atribuições estava o treinamento com os guias, organização das visitas escolares e, principalmente, organizar e participar de seminários e conferências e lecionar no curso de Early American Culture, do Winterthur Museum/University of Delaware.

Em 1974, durante um seminário desenvolvido na Universidade de Delaware, cuja temática girava em torno do artefato na história dos Estados Unidos, Fleming apresenta e publica o texto Artifact Study: A proposed model, publicado posteriormente pelo periódico Winterthur Portfolio, editado pela própria instituição, onde desenvolve uma metodologia específica para análise de objeto a partir de estudo profundo de suas características intrínsecas e extrínsecas. Além da metodologia, no texto o autor aplica sua proposta a um objeto da coleção do museu.

Fleming morre em 1994 enquanto trabalhava numa pesquisa a respeito dos símbolos americanos, e seu arquivo se encontra em posse da Winterthur Library.

De acordo com o Fleming (1974, p.154), o modelo proposto foi desenvolvido sob orientação da História Cultural, podendo ser utilizado por outras áreas do conhecimento. O estudo utiliza duas ferramentas conceituais: modelo de classificação em cinco propriedades básicas do artefato (história, material, 
construção, design e função) e quatro operações a serem executadas nessas propriedades (identificação, avaliação, análise cultural e interpretação. O diagrama abaixo, criado pelo próprio autor, apresenta, de forma resumida, esses processos, a fim de facilitar uma visão geral do modelo.

Figura 33 - Diagrama do Modelo de Fleming

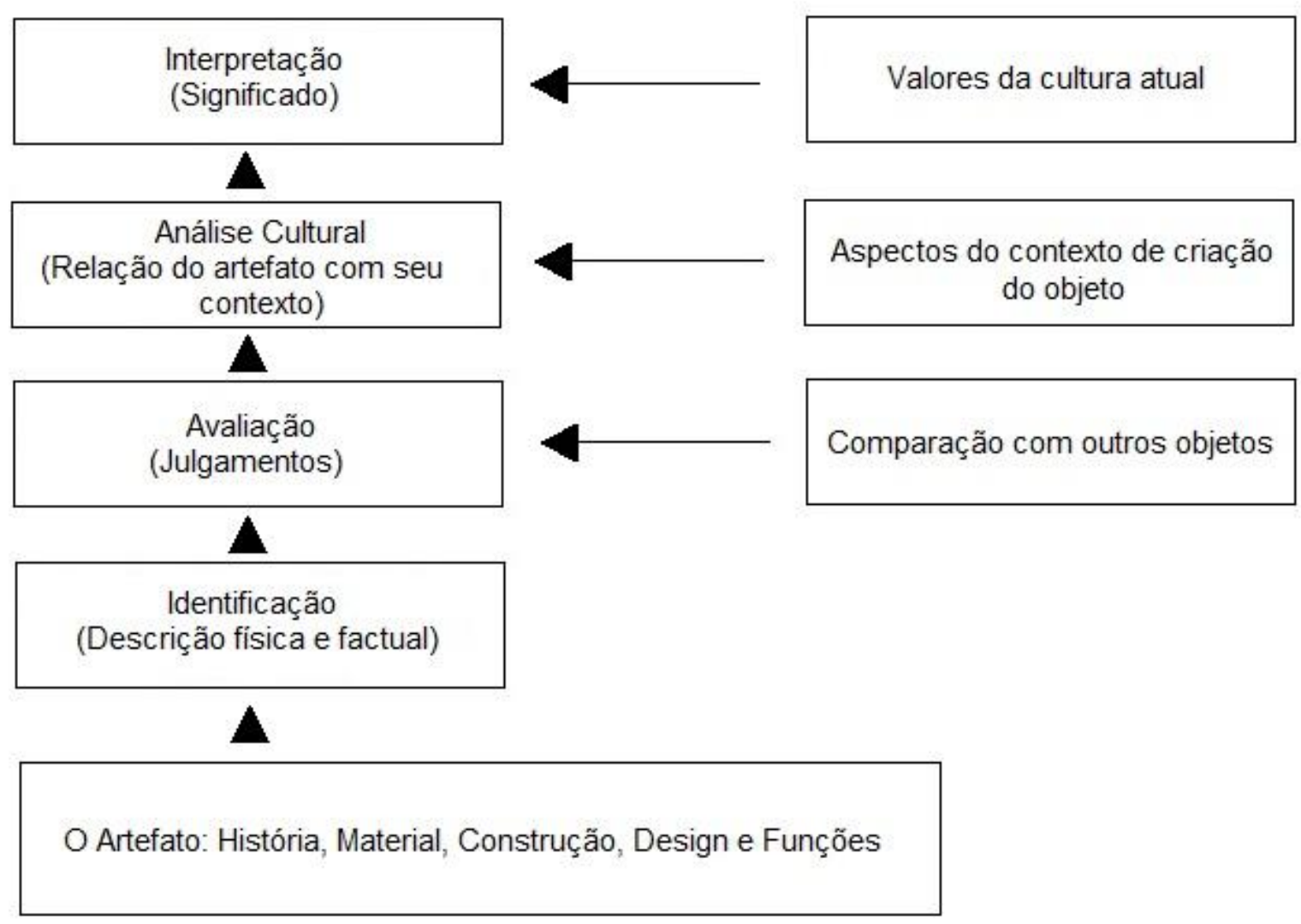

Fonte: traduzido de FLEMING, 1974, p.9

Segundo o próprio autor, "as cinco propriedades básicas fornecem uma formula para a inclusão e a inter-relação de todos os fatos significantes do objeto" (FLEMING, 1974, p. 156). De forma generalizada, essa propriedades incluem:

1) História - onde e quando o objeto foi feito, por quem e para quem, e o porquê de sucessivas mudanças de proprietários, condição e função;

2) Material - envolve de que o material é feito;

3) Construção - tem a ver com a técnica de manufatura, industrialização, como as partes são organizadas buscando informações sobre suas funções;

4) Design - inclui estrutura, forma, estilo, ornamento e iconografia; 
5) e Função - os usos (funções) e os papéis (valores e funções atribuídos) no objeto na cultura, incluindo utilidade, prazer e comunicação.

Tendo como base essas propriedades, parte-se para a análise de cada uma delas a partir das quatro atividades propostas: identificação, avaliação, análise cultural e interpretação.

A interpretação, primeira das atividades propostas por Fleming tem como objetivo fornecer informações exatas das cinco propriedades do objeto e é composta por dois momentos. O primeiro é a identificação do objeto e sua classificação, ou seja, do que se trata. $O$ autor chama atenção para a necessidade de sistematização do vocabulário a ser utilizado nesse ponto da pesquisa, o que dialoga diretamente com o proposto nos sistemas de organização da informação aplicado em ambiente museológico, mais precisamente na Documentação em Museus: "A adoção de um esquema classificatório mais uniforme e exato deve ser considerado como item prioritário no desenvolvimento de métodos rigorosos de estudos de cultura material" (FLEMING, 1974, p.156)

O segundo momento da identificação compreende a autenticação e descrição. A autenticação determina se o objeto é genuíno, incluindo dados de procedência, autoria, material e construção, buscando determinar se o objeto é original, falso ou réplica. $O$ autor identifica, nesse momento, o papel fundamental do especialista: somente a pessoa com conhecimento poderá atestar a autenticidade do objeto. Já a descrição, pré-condicionada pela autenticação, especifica os aspectos físicos do objeto, de forma concisa e ordenada, incluindo informações acerca das dimensões (medidas e peso), bem como uma descrição escrita e/ou fotográfica do objeto.

Após a interpretação, Fleming orienta a proceder com a avaliação, em termos dos valores culturais agregados. É na avaliação que verificamos a atribuição de valores como único, vanguarda, entre outros que identificam, principalmente, o porquê daquele objeto estar dentro de uma instituição museológica.

Para o autor há dois tipos de avaliação possíveis: o julgamento de qualidade estética, que possibilita atribuição de valores como excelente, bom, regular e dependente do exercício subjetivo do observador de determinar seu gosto e discriminações; e a comparação factual do objeto com outros semelhantes. 
A identificação e a avaliação constituem, então, o âmbito da pesquisa do curador da coleção e do especialista, uma vez que ambas fornecem as noções básicas do objeto que possibilitam generalizações mínimas para as outras duas atividades propostas por Fleming no campo do estudo dos objetos.

A terceira atividade proposta é a análise cultural, ou seja, examinar profundamente a relação entre o artefato e os aspectos da cultura onde ele foi criado. Segundo Fleming, a análise cultural possibilita transpor o estudo do objeto de uma simples análise descritiva para uma explanação mais abrangente. Aqui são identificados as funções que o artefato exerceu durante toda a sua vida no meio social, ou seja, antes de sua musealização, e envolvendo aspectos concretos e abstratos, as razões de sua produção, os vários usos, intencionais e atribuídos. Nessa fase o autor, também, identifica a necessidade de uso de vocabulários controlados e do auxílio de especialistas das áreas de conhecimento afins ao objeto.

A análise cultural revela a importância e os significados do objeto. De um modo geral, a principal função de um objeto é sua utilidade. No entanto, segundo o autor, conforme a pesquisa se desenvolve é possível identificarmos os comportamentos do homem associados ao objeto e aos grupos sociais e estruturas relacionados a esse comportamento.

Em relação ao material, design, construção e uso, verifica-se a função do objeto enquanto veículo de comunicação dos valores, ideias e significados, podendo, em alguns casos, indicar como o objeto se tornou agente de profundas mudanças sociais, econômica e culturais.

Outro aspecto indicado pelo autor como primordial na terceira etapa de estudo do objeto diz respeito à análise histórica do objeto: quantidade produzida, questões de mercado e econômicas, preços, e relações com outros documentos, escritos, pictóricos, entre outros. Segundo Fleming, esse tipo de pesquisa possibilita entender sua função social se seu uso foi restrito a uma classe ou subcultura ou se foi mais geral. "Qualquer o significado do objeto para a cultura e como transmite esse significado é parte essencial para a análise cultural" (FLEMING, 1974, p. 158).

Fleming indica que é possível, também, fazermos comparações com outros objetos, isolá-los a partir de uma característica comum, ou em grupos, e poderemos 
identificar questões que possibilitem extrair dados referentes à cronologia das técnicas de construção e do design.

De forma resumida é possível identificar na análise cultural a verificação de que o objeto pode ser estudado a fim de estabelecer fatos históricos, que indicam o nível tecnológico da sociedade, os materiais mais usados, as preferências formais e gostos, qualidade na manufatura, relações de troca, padrões e estilo de vida e usos sociais, nos quais a estrutura da interpretação histórica pode ser sustentada. Ou seja, é com a análise cultural que identificamos o espectro documental do objeto.

E por último, porém não menos importante para o modelo de Fleming, a quarta atividade proposta pelo autor é a interpretação. Essa atividade, mais subjetiva, é uma avaliação do objeto para a cultura do pesquisador.

Mais especificamente, a interpretação está focada na relação entre algum fato conhecido do artefato e algum aspecto-chave do nosso atual sistema de valores, e essa relação tem que ser suficientemente intensa ou rica a ponto de ter seu significado, significância ou relevância evidente. (FLEMING, 1974, p. 161)

Ainda segundo o autor (FLEMING, 1974, p.161) a interpretação não significa a elaboração de um documento comprovando fatos, e sim de uma análise subjetiva que vá além da documentação, uma vez que as informações particulares que são destacadas nessa fase são elaboradas a partir dos dados extraídos nas três primeiras fases da análise do objeto.

\subsubsection{O Modelo de Prown}

O modelo de Prown é um dos mais conhecidos na área da Cultura Material, em especial dos profissionais voltados para as Artes Aplicadas, área de onde se desenvolveu (LUBAR; KINGERY, 1993).

Jules Prown se graduou no Lafayette College and na University of Delaware, pelo Early American Cultura Program, assim como Fleming. Foi membro do Departamento de História da Arte, dessa universidade, no mesmo período em que exerceu a função de curador de arte americana no Yale University Art Gallery.

Participou da fundação do Yale Center for British Art, onde se especializou nessa tipologia de acervo e passou a exercer o cargo de professor de História da 
Arte na Yale University. Durante sua pesquisa na instituição, desenvolveu o modelo aqui estudado que, tal como o de Fleming, foi publicado no periódico Wintethur Portfolio, em 1982.

Apesar de ter sido originado no âmbito das Artes Aplicadas, conforme já citado, o modelo de Prown apresenta aspectos de estudos sociais e linguísticos. $O$ modelo não prevê esquemas e tem como característica marcante a subjetividade da análise feita no objeto.

Segundo o autor, trabalhar com exemplares do patrimônio, ou "artefatos como evidência" (PROWN, 1994, p. 133), é exercício constante da Arqueologia e da História da Arte. No entanto,

a exploração dos padrões de crença e comportamento, num fronteira intelectual onde os interesses das humanidades e das ciências sociais emergem, requer uma abertura para outras metodologias, incluindo as da História Social e Cultural, Antropologia Social e Cultural, Psico-história, Sociologia, Geografia Cultural, folclore e vida popular, e Linguística. (PROWN, 1994, p.133)

A partir desse pensamento, o autor desenvolve a metodologia proposta, dividida em três fases - descrição, dedução e especulação - cada uma com suas subfases.

A descrição está restrita ao que pode ser inferido a partir da observação, ou seja, o que é intrínseco ao objeto. Na prática, e segundo Prown, deve-se começar de uma observação em nível macro, para um nível micro. O autor chama atenção para a terminologia a ser usada, indicando a utilização de um vocabulário controlado. Por ser uma fase descritiva, deve ser extremamente objetiva, não tendo espaço para hipóteses ou conclusões subjetivas. A fase da descrição é exatamente o que Mensch denomina informações intrínsecas do objeto.

Dentro dessa primeira fase, o trabalho é realizado em três momentos. O primeiro é análise substancial, ou seja, descrição física. A análise substancial é um “inventário físico-descritivo do objeto" (PROWN, 1994, p. 134).

O segundo momento é análise de conteúdo. Segundo o autor, a análise de conteúdo é somente aplicada a objetos decorativos ou artísticos. A análise de conteúdo é uma descrição temática, incluindo questões decorativas e de motivos. 
O terceiro subitem da primeira fase é a análise formal, ou identificação do formato. Inclui dados acerca das dimensões, cores, formatos, organização espacial, padrões, distribuição, entre outros aspectos relacionados à configuração do objeto.

A segunda fase do modelo proposto por Prown é a dedução. Nessa fase o foco do estudo sai do objeto em si e passa a ser a relação com o observador: "envolve a ligação enfática do material (atual) ou mundo representado do objeto com o mundo de existência e experiência do observador." (PROWN, 1994, p. 135) O que o autor pretende é que o observador imagine como seria interagir com ou viver no mundo daquele objeto. Mesmo com caráter subjetivo, o autor afirma que as deduções, advindas da descrição, não estando dentro de um padrão de razoabilidade, devem ser consideradas hipóteses e transferidas para a terceira fase.

A fase da dedução é dividida em três momentos: experiência sensorial, experiência intelectual e resposta emocional.

A experiência sensorial é feita a partir do toque e, se possível, do uso do objeto. O observador obtém informações acerca da textura, do peso, da experiência arquitetônica, desenvolvendo um inventário das percepções sensoriais. No caso de pinturas, o autor indica que essas percepções devem ser feitas do que se pode inferir de sensações do que é retratada: o que ele estaria sentindo, que gostos estaria provando, que cheiros sentindo, entre outras sensações passíveis de imaginar a partir da observação.

A experiência intelectual depende do conhecimento prévio do observador a respeito do objeto, da área de conhecimento responsável por aquele objeto, e inclui informações relacionadas à função do objeto, do modo de emprego e inferências de experiências prévias com o objeto. Nas obras de arte o autor inclui na experiência intelectual a interpretação do retrato.

E, completando a dedução, o terceiro momento, a resposta emocional, diz respeito à reação do observador ao objeto. $O$ autor chama atenção para o fato de uma resposta emocional, por vezes, possa ser comum a muitos observadores. "Um objeto particular pode causar alegria, medo, temor, perturbação, asco, indiferença, curiosidade ou outra resposta que pode ser sutilmente distinguido". (PROWN, 1994, p. 136) 
A terceira, e última, fase da metodologia de análise de objetos proposta por Prown é a especulação. Da descrição do objeto, passando pela dedução, o observador agora passa para a fase em que o foco é a associação de ideias e percepções, aliada ao senso comum e julgamentos. Essa fase é dividida em dois momentos: teorias e hipóteses e programa de pesquisa.

No primeiro momento, revisando os dados coletados nas duas primeiras fases do método, o observador formula teorias e hipóteses que expliquem os dados coletados na descrição e nas experiências, com o mínimo de possibilidade de incorrer em julgamentos diacrônicos e buscando coletar informações da cultura que criou o objeto.

E, por fim, o observador desenvolve um programa de validação científica das informações coletadas. No entanto, isso não quer dizer que a metodologia proposta por Prown tenha chegado ao fim, uma vez que o objeto continua sendo fonte de informações e pode ser foco de novos estudos e novas análises buscando respostas para os questionamento surgidos na validação da informações coletadas na descrição, na dedução e na especulação.

\subsubsection{O Modelo de R. Elliot}

Robert S. Elliot, historiador da tecnologia canadense, como os outros autores aqui analisados, também desenvolveu um modelo para análise de objetos em âmbito acadêmico e museológico. R. Elliot trabalhou como curador do New Brunswick Museum, na Divisão de Humanidades, e faz parte do projeto do Dictionary of Canadian Biographies.

O método proposto por R. Elliot foi desenvolvido em conjunto com outros profissionais e alunos do programa de pós-graduação em estudos de museu, na New Brunswick University, e publicado, oficialmente, no periódico Material History Bulletin, $n^{\circ}$ 22, em 1985. A metodologia é fruto do esforço intelectual desses profissionais que, no contexto de um seminário, se debruçaram sobre a temática do estudo dos objetos.

$\mathrm{O}$ artigo aqui analisado, redigido em forma de relatório, foi dividido em três partes, a saber: (i) uma breve explicação teórica do método e como ele foi 
desenvolvido; (ii) uma explicação prática do método; e (iii) aplicações desse método buscando verificar sua usabilidade em diversos tipos de objeto.

$\mathrm{Na}$ primeira parte do artigo, a equipe encabeçada por R. Elliot explica o método e como ele foi desenvolvido. Segundo os autores, num primeiro momento, os participantes do seminário buscaram referências que já haviam trabalhado a temática da Cultura Material e os métodos de análise de objeto e verificaram que a maior contribuição foi da Arqueologia. Assim sendo, o método proposta parte de uma perspectiva histórica.

Foi levantado, também, dois modelos desenvolvidos por outros profissionais Fleming e Prown. A questão central que norteou a pesquisa era: esses modelos são passíveis de utilização em qualquer tipo de acervo? Dessa forma, os modelos foram analisados buscando identificar esta aplicabilidade e, caso contrário, adaptar desses modelos à demanda das instituições de pesquisa. Fleming e Prown, então, serviram de base para o modelo proposto pela equipe comandada por R. Elliot.

Segundo os autores, o modelo proposto por Fleming era complexo para o trabalho e apresentava dubiedades nas categorias dos objetos estudadas no método. No entanto, era possível adaptá-las. Então, assim como em Fleming, o modelo elaborado pelos participantes do seminário é baseado em cinco características do objeto: Material, Construção (incluindo design e descrição física do objeto), Função, Procedência (histórico) e Valores. Os autores afirmam, ainda, que é necessário seguir essa ordem no estudo, uma vez que parte do mais empírico (descrição e material) ao mais interpretativo (valores).

Outra questão que norteou os pesquisadores ao elaborar o método aqui descrito foi a possível categorização dos objetos para o estudo. Dessa forma analisaram Prown e as categorias de objetos elaboradas em seu artigo ${ }^{85}$, e verificaram que além de subjetivas, essas categorias se apresentavam redundantes, levando os pesquisadores a abandonar a ideia de categorizar os objetos.

Durante todo o seminário, foram realizados testes com as estudos que iam sendo estabelecidos, buscando desenvolver metodologia que alcançasse o máximo possível os objetivos propostos no evento. Após um desses testes foram

\footnotetext{
${ }^{85}$ Prown desenvolve uma categorização dos objetos que parte, tendo como base sua função: arte - diversão adorno - modificação da paisagem - artes aplicadas - utilitários.
} 
estabelecidos grupos de questões e de informações a serem levantadas durante o estudo do objeto:

- Grupo A: Perguntas passíveis de serem respondidas por meio da observação, ou seja "dados que podem ser determinados pelo compromisso sensorial com o artefato [...]" (ELLIOT, R. et. al., 1994, p. 117)

- Grupo B: Perguntas respondidas por meio da comparação de objetos semelhantes ou idênticos, ou produzidos pelo mesmo fabricante durante o mesmo período temporal, entre ouros parâmetros comparativos.

- Grupo C: Perguntas respondidas com auxílio de documentos externos e complementares (tais como livros, documentos arquivísticos, história oral, entre outros);

- E Grupo D: Informações conclusivas a partir das respostas dos grupos anteriores.

A partir da delimitação desses grupos foi elaborado o esquema abaixo, que sintetiza a metodologia do estudo:

Figura 34 - Diagrama do Modelo de R. Elliot

\begin{tabular}{l|l|l|l|l|l|}
\multicolumn{1}{c}{ Material } & \multicolumn{1}{c}{ Construção } & & & \\
\cline { 2 - 6 } $\begin{array}{l}\text { Passo 01: } \\
\text { Dados Observáveis } \\
\text { (Grupo A) }\end{array}$ & & & & & \\
& & & & & \\
$\begin{array}{l}\text { Passo 02: } \\
\text { Dados } \\
\text { Comparativos } \\
\text { (Grupo B) }\end{array}$ & & & & & \\
\cline { 2 - 6 } & & & & & \\
$\begin{array}{l}\text { Passo 03: } \\
\text { Dados } \\
\text { Complementares } \\
\text { (Grupo C) }\end{array}$ & & & & & \\
\cline { 2 - 6 } & & & & & \\
Passo 04 & & & & & \\
\end{tabular}

Fonte: traduzido de Pearce, 1994, p. 114 
A metodologia proposta pelos pesquisadores prevê a realização do estudo em quatro passos, abarcando todas as cinco características do objeto, e indica a criação de uma gramática própria para a análise do objeto. O movimento proposto vai da examinação do objeto (observação, exercício mental ou escrito) para, depois, buscar em outras fontes de informações. No entanto, ao recuperar uma informação importante, o método prevê o livre retorno à fase de observação.

\subsubsection{O Modelo de Pearce}

O modelo de Pearce, como a própria autora indica no início de seu texto, é derivado do modelo de Fleming, com traços do de Montgomery. No entanto, ao contrário do modelo-base, Pearce busca aplicação na área da Arqueologia e da Museologia, fazendo modificações no modelo de Fleming.

Cabe ressaltar a importância que esse modelo dá ao processo curatorial e à aplicação da teoria da Cultura Material ao ambiente museológico. Segundo a autora, "estudos da cultura material musealizada devem ser postos sobre uma base teórica mais completa e segura" (PEARCE, 1994, p. 125).

A autora ainda traz contribuições da linguística para entendermos a importância do estudo dos objetos. Para Pearce, objetos são aspectos objetivos em relação à natureza subjetiva do homem. Ou seja, organizando as propriedades dos objetos, para análise, é possível identificarmos seus aspectos materiais, sua história e ambiente de uso, bem como sua significação para a comunidade que o criou ou usou.

Antes de iniciar a explanação de suas modificações no modelo de Fleming, a autora faz uma breve análise dos modelos pioneiros de Montgomery e de Fleming, justificando suas modificações.

Para Pearce, o modelo de Montgomery, que também é baseados em passos/exercícios de descrição do objeto, apresenta um único 'defeito': a ênfase nas questões referentes ao connoisseurship, à manufatura, e na afirmação de que um "olho treinado pode julgar o sucesso de um artefato como obra de arte" (PEARCE, 1994, p.126). A autora afirma que sucesso ou falha são questões irrelevantes para o estudo da cultura material, mesmo que suas qualidades, ao serem comparadas com 
as de outros objeto de mesma natureza, sejam importantes para a compreensão geral da coisa entender as atribuições de valores.

Já o modelo de Fleming, segundo Pearce, apresenta uma metodologia apropriada para o estudo do objeto. No entanto, a autora identifica fraquezas nas questões terminológicas e de divisão das categorias. Segundo o modelo de Fleming, as cinco propriedades básicas do objeto são história, material, construção, design e função. Pearce não concorda, indicando os seguintes aspectos negativos do modelo: a linha que distingue construção de design é muito tênue e que ambas as categorias devem ser estudadas juntas com a categoria material; a função diz respeito a como o objeto foi usado e deve ser entendida como parte de sua história; as relações espaciais do objeto são omitidas, aparecendo, somente, durante o processo de análise cultural; a significância do objeto não está clara na categoria função, utilizada no modelo para cobrir os aspectos de uso e papéis desempenhados pelo objeto, descrito como incluindo deleite e comunicação como função não-intencionais.

Para a autora, as quatro propriedades a serem trabalhadas podem ser denominadas: Material, História, Meio Ambiente e Significado. A partir dessa crítica, Pearce inicia a explanação de seu modelo.

Conforme é possível verificar na figura 23, o modelo proposto por Pearce segue o mesmo padrão do modelo de Fleming, com algumas alterações e mudanças de caráter terminológico e conceitual.

As duas colunas dizem respeito: (i) às propriedades do artefato (lado esquerdo); e (ii) às ações a serem empreendidas no estudo.

O ponto de início óbvio é o corpo físico do objeto, os componentes com os quais o objeto foi construído, e qualquer ornamento que possa ter sido adicionado, e assim o estudo do objeto começa com sua descrição física. Inclui uma descrição física escrita da construção e do conjunto ornamental em linguagem técnica apropriada, com medidas relevantes, desenhos, fotografias, raios-x, ou em outras palavras, a documentação que, quando possível, o curador irá querer anexar ao documento de recebimento do objeto. (PEARCE, 1994, p. 128, tradução nossa) 
Figura 35 - Diagrama do Modelo de Pearce

O artefato tem material, história, meio ambiente e significância

1

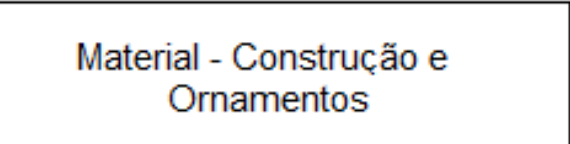

Materal - Design do objeto e da parte ornamental

Material - Caracterização:

3

1- procedência; e 2- técnicas industriais

História: 1- sua própria história;

4

2- sua história subsequente; e 3-

sua função prática

Meio Ambiente: Contexto micro e macro

Meio Ambiente: Localização

1- na paisagem; 2- em relação com o padrão

$$
7
$$

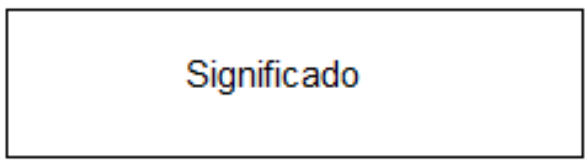

Interpretação - papel do artefato na organização social
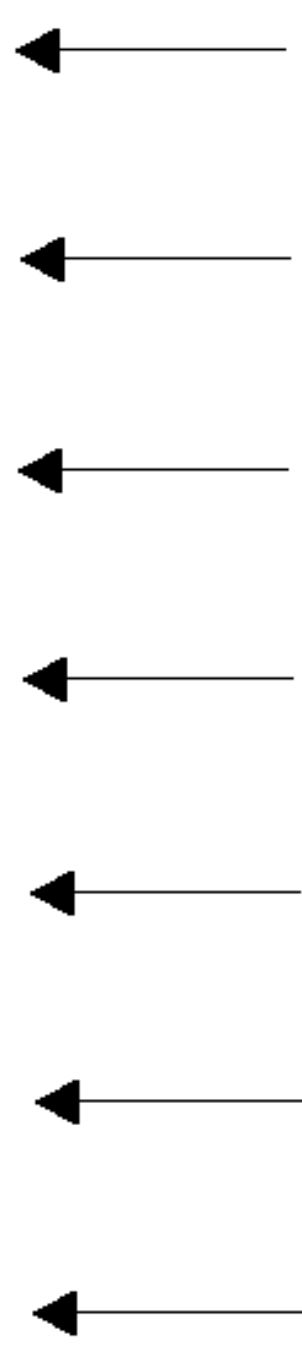

Registros locais, pesquisa

Datação, etc, técnica, pesquisa documentária relevante

Comparação com outros artefatos a fim de criar cateqorias tipológicas

Comparação com outras amostras e objetos

Sistemas filosóficos e psicológicos escolhidos

Soma de estudo prévio, corpo de conhecimento cultural e técnicas analíticas

Fonte: traduzido de Pearce, 1994, p.128

Assim sendo, as três primeiras atividades previstas no modelo de Pearce ( $\mathrm{n}^{\circ} \mathrm{s}$ 1, 2 e 3) dizem respeito ao material, primeira das propriedades do objeto a serem trabalhadas. A primeira fase gira em torno da análise física do objeto. O principal objetivo, segundo Pearce, é que esse estudo possibilite identificar o encaixe do 
objeto em uma determinada categoria. O estabelecimento dessas categorias, ou a inclusão do objeto nessa classe, não é feita de forma subjetiva - ou como a autora fala "da cabeça do curador" - uma vez que, ao comparar com outros objetos iguais, as próprias coisas demonstram suas ligações objetivas, levando-os aos grupos aos quais pertencem.

Em um segundo momento, procede-se, então, à comparação com objetos semelhantes. Essa atividade favorece a diminuição na subjetividade da classificação do objeto, bem como auxilia na delimitação de procedência e datação.

Essas análises comparativas têm sua importância reiterada por Baudrillard quando, em sua teoria do objeto, ele afirma que "[...] neste mundo de signos, eles [os objetos] escapavam rapidamente de seu valor de uso para estabelecer entre eles um jogo, para se corresponder" (BAUDRILLARD, 2007, p.10).

Por último, e completando os três primeiros pares de células do modelo de Pearce, orienta-se um estudo aprofundado dos materiais utilizados na construção do objeto, buscando estabelecer a procedência e as formas de uso desses materiais, antes e durante da manufatura.

A segunda propriedade dos objetos a ser trabalhada é a História (nº 4). Aqui, diferentemente dos primeiros três passos, a pesquisa deverá ser feita contando com aparatos externos, como outros tipos de documentos (arquivo, biblioteca, etc) bem como de técnicas específicas de pesquisa, como datações químicas.

A próxima, e terceira propriedade a ser foco de estudo é o Meio Ambiente (nํs 5 e 6). Segundo a autora "objetos existem em relação geográfica com outros objetos e com a paisagem e o estudo dessas relações podem ser produtivos para nosso entendimento do papel do artefato" (PEARCE, 1994, p.130).

O estudo do meio ambiente em que o objeto foi criado visa estabelece o contexto em que o objeto foi criado, tanto em escala micro, como em escala macro: em que local e circunstância se deu essa manufatura, qual a necessidade, em que local era guardado e usado, enfim, tudo o que diz respeito ao meio social em que o objeto foi criado. Faz-se importante, também, o desenvolvimento de mapas de distribuição do objeto, buscando entender os padrões de criação, padrões estéticos, entre outros. Nesse ponto da análise, a autora chama a atenção para o cuidado que 
o pesquisador deve ter, uma vez que muitas dessas informações podem ter se perdido, o que dificulta o trabalho.

A terceira propriedade, e de certa forma a etapa mais subjetiva, é identificar o significado do objeto para a sociedade. Pearce ressalta que o objeto deve ser analisado em todos os momentos de sua vida social: do momento em que foi criado, os valores atribuídos, até sua musealização, exemplificando com uma máscara Yorubá que, ao ser criada na África ela tinha um significado, e ao fazer parte de uma coleção museológica outro valor lhe é atribuído.

Nessa fase, então, em que é estudado o papel do objeto - aspectos em níveis individuais e coletivos. "Objetos são importantes para as pessoas porque eles demonstram prestígio e posição social; em termos sociais, a maioria das peças que sobrevivem (...) são por esse motivo" (PEARCE, 1994, p.131). Essa atividade tem intrínseca ligação com o que Pomian denomina como papel do objeto de ligar o visível ao invisível (semióforo).

É possível analisar esses papéis de uma forma mais sistemática, para produzir uma base teórica que os tornará mais inteligíveis de maneira mais universal e menos específica? Um seguidor de Jung pode argumentar que nós investimos os objetos com significância simbólica formando pontes entre o consciente e o inconsciente ou elementos ocultos em nossa personalidade, nos ajudando para chegar a um acordo com características socialmente indesejáveis (PEARCE, 1994, p.131).

A última ação prevista no modelo é a interpretação. Nessa fase são agrupadas todas as informações acumuladas nas três fases anteriores de forma a criar um painel amplo que possibilite uma análise social do objeto de buscando criar uma imagem geral do objeto na sociedade.

Concluindo seu modelo, Pearce (1994, p.131) afirma que nem todo tipo de material que compõem as coleções museológicas são capazes de responder de forma completa a esse modelo, ressaltando que sua intenção ao criar o modelo foi desenvolver um método para estudo de objetos que possibilitasse o início de pesquisas, uma vezs que os objetos irão responder, particularmente, com diferentes profundidades de informação. 


\subsubsection{O Modelo de Batchelor}

Dr. Ray Batchelor é diretor e coordenador da Faculdade de Design, Media and Management (Design, Midia e Gestão) e professor de Cultura Material e Visual na escola de Design, Craft and Visual Arts (Design, Ofícios e Artes Visuais), na Buckinnghamshire New University. Suas pesquisas são centradas no desenvolvimento do design e da tecnologia na Inglaterra.

Foi curador do Science Museum de Londres, onde, a partir de seu trabalho com a coleção, desenvolveu um modelo de estudo de objetos buscando demonstrar que as coisas são passíveis de interpretação multifacetada (PEARCE, 1994). Seu estudo foi publicado pela primeira vez como artigo no Museum Professionals Group Anual Study Weekend (1984) em Liverpool, e, posteriormente, publicado no periódico Museum Professionals Group News (no23, 1986).

Nesse modelo, Batchelor, assim como Prown, evita a elaboração de esquemas para o estudo do objeto. E, como forma de ilustrar a aplicação do modelo, ele se apropria de uma chaleira do século XX - objeto de produção em massa.

Batchelor descreve seu modelo em seis etapas, a saber: (i) a ideia ou a invenção; (ii) o material com o qual é feito o objeto; (iii) fabricação ou manufatura; (iv) mercado; (v) arte; e (vi) uso.

Na primeira etapa, a Ideia, o autor indica que deve ser feita observação direta a fim de identificar toda história e a evolução por trás do objeto. Ou seja, o foco da observação é a tecnologia. Apesar de não ser indicado pelo autor, para identificar algumas características, é preciso ajuda de outras fontes. No exemplo da chaleira, ele identifica o período em que ela foi manufaturada a partir das características formais da peça, tendo como base para datação, aspectos do desenvolvimento tecnológico.

A segunda etapa, referente ao material, o autor afirma que é possível verificar, a partir da matéria-prima, indicar funções, relações, aspectos valorativos e de aplicação. Um objeto feito com materiais baratos, pode indicar que o objeto é um artigo utilitário, comum; ao contrário, um objeto feito com metais nobres, como o ouro, pode indicar artigo de luxo, ou até mesmo para ornamentação. 
A fabricação, terceira etapa, está intimamente ligada à segunda, à medida em que "a escolha do método de manufatura é, por sua vez, governada pela escolha do material [...] e deve satisfazer as demandas práticas e estéticas do design" (BATCHELOR, 1994, p. 140) Segundo o autor, essas informações podem ser recolhidas apenas pela observação do objeto. Batchelor afirma que qualquer pesquisador tem essa habilidade, independente se sua prática está voltada para as artes ou para a tecnologia.

O quarto aspecto a ser estudado é o mercado (marketing). Ou seja, todo o meio ambiente comercial do objeto, considerando as trocas em um contexto amplo. (BATCHELOR, 1994, p. 141) Esse estudo possibilita ter uma visão geral do valor mercadológico (comercial e valorativo) da peça e graus comparativos com outros objetos relacionados à peça estudada.

O autor chama atenção, ainda, para esse aspecto do objeto, normalmente, ser ignorado nas atividades museológicas. Alguns autores, principalmente os voltados para a Antropologia e Etnologia, desenvolveram o conceito de Biografia dos Objetos, já trabalhado nessa dissertação, que dialoga diretamente com essa etapa do estudo do objeto.

A características artísticas e de design (aspectos formais) da peça são estudadas na quinta etapa do método proposto por Batchelor.

E, por último, o autor propõe que seja analisado o uso do objeto: a chave para entender um objeto está em seu uso. (BATCHELOR, 1994, p. 142)

Finalizando seu texto, o autor indica a importância dos objetos como fontes de informação e seu papel em ambiente museológico:

Objetos são nossos arquivos primários. Temos que entender suas vários significados da forma mais ampla possível. Dito isto, eu duvido que o público queira saber tudo de tudo. [...] Mas, antes de resolver por essa charmosa e atraente cena [o autor se refere à cena expográfica descrita anteriormente em que a chaleira poderia estar exposta], temos que examinar, primeiramente, toda a informação que o objeto apresenta e ilustra [...] (BATCHELOR, 1994, p. 143)

De acordo com o autor, tendo realizado esse estudo completo, podemos identificar qual informação é a que responde determinada demanda da instituição. 


\subsection{Análise Comparativa dos Estudos de Cultura Material}

Os modelos descritos no capítulo 4.2. dessa dissertação foram analisados tendo como objetivo a identificação de uma metodologia para aplicação em museu de ciência e tecnologia. Como visto anteriormente, "esse trajeto pode ser explicado pela inexistência de um modelo adequado para a leitura de objetos de C\&T" (GRANATO et. al., 2007. n/p.) e justificado na importância do objeto científico como fonte documental para a História das Ciências e das Técnicas.

Para a análise comparativa foram desenvolvidos parâmetros (ver quadro abaixo) para o estudo e identificação dos modelos de forma a alcançar os objetivos propostos pela pesquisa.

Quadro 11 - Parâmetros da Pesquisa

\begin{tabular}{|c|}
\hline PARÂmetros da PesquisA \\
\hline Origem disciplinar \\
\hline Contexto \\
\hline Aplicação em âmbito museológico \\
\hline Metodologia (aspectos teóricos) \\
\hline Metodologia (aspectos práticos) \\
\hline Níveis de informação analisados \\
\hline Produtos \\
\hline
\end{tabular}

A partir dos dados coletados foi avaliada a possibilidade de aplicação em museus de ciência e tecnologia, em especial de telecomunicações.

\subsubsection{Origem Disciplinar, Contexto e Aplicação em Âmbito Museológico}

O parâmetro Origem Disciplinar, junto ao parâmetro Contexto, previu a análise do ambiente de desenvolvimento do modelo: acadêmico, museológico ou outro contexto. Complementando os dois primeiros parâmetros foi analisado a 
indicação de aplicação em ambiente museológico, ou seja, se o autor previu o uso do modelo proposto em coleções museológicas, independente de sua natureza. Nos casos em que o método foi desenvolvido em contexto museológico, sua aplicação se torna óbvia.

Quadro 12 - Dados Coletados - Origem Disciplinar

\begin{tabular}{|l|l|}
\hline \multicolumn{1}{|c|}{ Modelo } & \multicolumn{1}{c|}{ DAdos Coletados } \\
\hline C. Montgomery & História da Arte e Artes Aplicadas \\
\hline E. M. Fleming & História da Arte e Artes Aplicadas \\
\hline J. Prown & História da Arte e Artes Aplicadas \\
\hline R. Elliot & História e Arqueologia \\
\hline S. Pearce & História, Arqueologia e Antropologia \\
\hline R. Batchelor & Design e Tecnologia \\
\hline
\end{tabular}

No que diz respeito à Origem Disciplinar foi verificado que somente um dos modelos não teve como origem direta a História ou de uma das áreas do conhecimento oriunda da primeira: o modelo de Batchelor (1994), desenvolvido a partir da demanda da coleção do Science Museum de Londres.

Montgomery (1999), Fleming (1974) e Prown (1982) apresentaram a mesma origem disciplinar: as Artes. No entanto, ao contrário do primeiro que apresenta um modelo totalmente orientado para os aspectos formais e artístico dos objetos, Fleming (1974) e Prown (1982) desenvolveram modelos que podem ser adaptados a outros tipos de acervo.

Fleming (1974) desenvolveu seu modelo tendo como base os objetos artísticos, porém sem focar, somente, nos aspectos estéticos, assimilando, também, as questões funcionais e de fabricação do objeto.

E Prown (1982) afirma que o trabalho com Cultura Material vai além dos esforços da Arqueologia e da História, sendo necessário, também, que o pesquisador oriente seu estudo buscando aporte na História Social e Cultural, na 
Antropologia Social e Cultural, na Psico-História, na Sociologia, na Geografia Cultural, no Folclore, na Linguistica e na vida popular.

R. Elliot (1994) e Pearce ${ }^{86}$ (1994), que desenvolveram os modelos dos autores supracitados, já apresentam visões a partir da História e da Arqueologia, possibilitando ainda mais a aplicação dos métodos em outras tipologias de coleção.

Informações a respeito do Contexto em que o modelo foi desenvolvido e a sua aplicação em âmbito museológico também foram avaliadas para corroborar com os resultados que levavam ao alcance dos objetivos da pesquisa.

\section{Quadro 13 - Dados Coletados - Contexto de Criação do Modelo}

\begin{tabular}{|l|l|}
\hline \multicolumn{1}{|c|}{ ModELo } & \multicolumn{1}{|c|}{ DADOs CoLETADos } \\
\hline C. Montgomery & $\begin{array}{l}\text { Montgomery desenvolveu o modelo a partir de um exercício } \\
\text { proposto aos seus alunos do curso de Arte Americana, na } \\
\text { Winterthur University. }\end{array}$ \\
\hline E. M. Fleming & $\begin{array}{l}\text { Desenvolvido em âmbito acadêmico. Modelo apresentado em } \\
\text { seminário promovido pelo grupo de pesquisa em Artes } \\
\text { Decorativas do Winterthur Museum. }\end{array}$ \\
\hline J. Prown & $\begin{array}{l}\text { Prown desenvolveu seu método tendo como pano de fundo o } \\
\text { trabalho de curadoria exercido no Yale Center for British Art. }\end{array}$ \\
\hline R. Elliot. & $\begin{array}{l}\text { Elaborado durante um seminário na New Brunswick University, } \\
\text { pelo o curso de graduação em História da instituição. }\end{array}$ \\
\hline R. Batchelor & $\begin{array}{l}\text { Pearce é professora do Curso de Museus da Leicester } \\
\text { University, onde ela desenvolveu o modelo em suas pesquisas } \\
\text { arqueológicas. }\end{array}$ \\
\hline autor dirigia o Science Museum, em Londres.
\end{tabular}

${ }^{86}$ É possivel identificar, inclusive, aspectos da teoria estruturalista de Lévi-Strauss no modelo Pearce, representando claramente a origem disciplinar da autora e de seu modelo. 
Quadro 14 - Dados Coletados - Aplicação em Contexto Museológico

\begin{tabular}{|c|c|}
\hline MODELO & DAdOS COLETAdos \\
\hline C. Montgomery & $\begin{array}{l}\text { Não há indicação explícita, porém o autor dava aulas no curso } \\
\text { de Arte Americana da Winterthur University e trabalhava como } \\
\text { curador no museu da mesma instituição. }\end{array}$ \\
\hline E. M. Fleming & $\begin{array}{l}\text { O autor indica a utilização do modelo no trabalho curatorial, ou } \\
\text { seja, na gestão e comunicação das coleções. }\end{array}$ \\
\hline J. Prown & $\begin{array}{l}\text { O autor identifica a importância dos modelos de estudo de } \\
\text { objeto para o trabalho em âmbito museológico, indicando, } \\
\text { inclusive, a necessidade dos aspectos filosóficos e } \\
\text { disciplinares da Cultura Material no trabalho dos museus }\end{array}$ \\
\hline R. Elliot & $\begin{array}{l}\text { Não há citação explícita da aplicação do modelo em Museus. } \\
\text { No entanto, R. Elliot, principal pesquisador do grupo, na } \\
\text { ocasião era curador do New Brunswick Museum. }\end{array}$ \\
\hline S. Pearce & $\begin{array}{l}\text { A própria autora já defende em seu texto a utilização do } \\
\text { modelo em contexto museológico. }\end{array}$ \\
\hline R. Batchelor & $\begin{array}{l}\text { Além de indicar para o trabalho em curadoria, Batchelor indica } \\
\text { seu modelo para que o museu defina suas políticas de gestão } \\
\text { do acervo. }\end{array}$ \\
\hline
\end{tabular}

Dos seis modelos analisados, somente dois não apresentam ligação direta com instituições museológicas: Montgomery (1999) e R. Elliot (1994). Ambas as metodologias estão ligadas a contextos acadêmicos e não apresentam indicação de aplicação em coleções de musealizadas. No entanto, cabe ressaltar que Montgomery (1999) e R. Elliot (1994) trabalhavam como curadores em instituições museológicas, o que nos leva a inferir que houve influência da Museologia no desenvolvimento de suas metodologias de estudo do objeto.

O modelo de Fleming (1974) também não foi desenvolvido em âmbito museológico. No entanto, ao contrário de Montgomery (1999) e R. Elliot (1994), o 
autor indica a utilização de seu modelo de estudo de objeto no trabalho curatorial em Museus e instituições afins.

E as metodologias desenvolvidas por Batchelor (1994), Pearce (1994) e Prown (1982) foram desenvolvidas em âmbito museológico, partindo da demanda de suas respectivas instituições.

Cabe ressaltar, ainda, que o trabalho de Pearce teve como pano de fundo o Curso de Museus da Leicester University, corroborando com sua aplicabilidade em museus e coleções.

E, Batchelor (1994), em seu modelo, comprova e reitera a possibilidade de aplicação em coleções musealizadas ou particulares ao aplicar a metodologia proposta em um chaleira de uso próprio.

\subsubsection{Metodologia de Estudo de Objetos Propostas nos Modelos}

Após a análise feita no contexto e na indicação de aplicabilidade do modelo em ambiente museológico, verificou-se como se desenvolve os estudos de objeto dos autores selecionados para a presente pesquisa.

Dessa forma, foram analisados os aspectos teóricos e práticos, incluindo objetivos e esquemas propostos, as ações previstas para e com o objeto e a atuação de outros profissionais e uso de outras tipologias de documento, como os arquivístico e os bibliográfico. Parte desses resultados já foi destrinchada na descrição de cada modelo, feita no ponto 5 dessa dissertação.

\section{Quadro 15 - Dados Coletados - Metodologia proposta nos Estudos de Cultura Material}

\begin{tabular}{|l|l|}
\hline \multicolumn{1}{|c|}{ Modelo } & \multicolumn{1}{|c|}{ Dados Coletados } \\
\hline \multirow{2}{*}{ C. Montgomery } & $\begin{array}{l}\text { O modelo de Montgomery divide a análise do objeto em } \\
\text { quatorze pontos e não prevê esquema. Além disso, foi } \\
\text { elaborado de forma a desenvolver o estudo a partir da } \\
\text { observação e comparação. Montgomery prevê a utilização de } \\
\text { outros tipos de documento para certificação dos dados } \\
\text { coletados. }\end{array}$ \\
\hline
\end{tabular}

(continua...) 
(continuação do quadro 15)

\begin{tabular}{|c|c|}
\hline E. M. Fleming & $\begin{array}{l}\text { O autor desenvolveu um esquema (ver p. 88) que facilita a } \\
\text { visualização da metodologia. O estudo é realizado por ações } \\
\text { de pesquisa estabelecidas pelo autor, onde o pesquisador } \\
\text { deve utilizar documentos externos para verificar as } \\
\text { informações coletadas do objeto, bem como prever a } \\
\text { participação de especialistas nas Áreas do Conhecimento da } \\
\text { coleção para fornecimento de informações técnicas do objeto. }\end{array}$ \\
\hline J. Prown & $\begin{array}{l}\text { O autor desenvolveu o estudo em três fases, com subfases, } \\
\text { sendo as primeiras duas totalmente feitas a partir de } \\
\text { observação do objeto e a última de validação das informações } \\
\text { coletadas. O estudo não indica o uso de documentos externos } \\
\text { e nem de profissionais especializados na temática do acervo. } \\
\text { Não prevê, também, esquemas que identifique visualmente as } \\
\text { fases e subfases do trabalho. }\end{array}$ \\
\hline R. Elliot & $\begin{array}{l}\text { O esquema apresentado (ver p. 96) foi desenvolvido a partir } \\
\text { do proposto por Fleming e por Prown, prevendo análise de } \\
\text { cinco características do objeto a partir de grupos de } \\
\text { informação elaboradas na formato de perguntas. A } \\
\text { metodologia proposta é flexível, porém com diretrizes, } \\
\text { terminologias e gramáticas específicas. É prevista a utilização } \\
\text { de outras tipologias de documento. }\end{array}$ \\
\hline S. Pearce & $\begin{array}{l}\text { O desenho da pesquisa (ver p. 99), assim como a de R. Elliot, } \\
\text { foi desenvolvido a partir do modelo de Fleming, divergindo do } \\
\text { autor somente no número de ações de pesquisa. O estudo } \\
\text { desenvolvido pela autora parte de uma análise mais } \\
\text { específica, para uma análise mais geral (do micro para o } \\
\text { macro). Prevê, também, a utilização de outros documentos. }\end{array}$ \\
\hline R. Batchelor & $\begin{array}{l}\text { Não é proposto esquema. Batchelor dividiu seu estudo em } \\
\text { seis etapas baseado na observação. Não prevê a participação } \\
\text { de profissionais e nem a utilização de outros documentos. }\end{array}$ \\
\hline
\end{tabular}


Os modelos de Fleming (1974), R. Elliot (1994) e Pearce (1994) apresentaram diagramas elaborados a partir da metodologia proposta, que facilita o entendimento e a visualização de todas as etapas do trabalho. Apesar de o grupo de R. Elliot e Pearce terem desenvolvido seus modelos a partir do proposto por Fleming e por Prown (1982), é possível verificar alterações substanciais no que diz respeito à terminologia e metodologia empregadas.

O primeiro, desenvolveu seu método a partir de quatro ações a serem empregadas sobre cinco características do objeto. R. Elliot (1994) modificaram essas quatro ações de Fleming (1974) e adaptaram para três fases diferentes sobre cinco características. E Pearce modificou o esquema de Fleming para oito ações e oito fases a serem desenvolvidas em quatro características.

Tanto R. Elliot. quanto Pearce modificaram, também, a terminologia empregada no modelo de Fleming, adaptando para as necessidades de cada autor em seu respectivo contexto de atuação.

O grupo de R. Elliot desenvolveu o modelo a partir de grupos de questões sobre o objeto a serem respondidas pelo pesquisador, enquanto Fleming e Pearce baseiam seus modelos na observação - coleta de dados no próprio objeto - e na comparação com outros exemplares.

Montgomery (1999), Prown (1982) e Batchelor (1994) não apresentaram diagramas de seus modelos. No entanto, é possível verificar que os três modelos apresentam metodologia simplificada, o que justifica uma não apresentação de esquemas.

Montomery (1999) desenvolveu um método baseado no conhecimento do pesquisador (connoisseurship ${ }^{87}$ ) e estabelecido sobre quatorze pontos de análise de informação sobre o objeto, realizada a partir da observação e da comparação.

Prown (1982) propõe um método em três fases, sendo duas com coleta de dados de forma subjetiva, e uma terceira para certificação das informações coletadas nas duas primeiras fases do estudo.

E Batchelor (1994) desenvolveu seu método baseado em seis fases de estudo onde os dados são coletados por meio da observação. Segundo o autor, por

\footnotetext{
${ }^{87} \mathrm{O}$ que podemos fazer paralelo à teoria de Bourdieu do Poder Simbólico. Ver Lima.
} 
ser um método proposto para aplicação em qualquer objeto - musealizado ou não -, qualquer pessoa pode aplicar o método a uma peça.

Dos seis modelos aqui analisados, somente o modelo de Fleming (1974) prevê consulta com profissionais espececializados na temática da coleção. Montgomery (1999), Prown (1982), R. Elliot (1994), Pearce (1994) e Batchelor (1994) não indicam essa participação, deixando o trabalho de pesquisa para o profissional que se debruçou sobre o objeto para aplicação de seus método.

Ainda no que diz respeito à certificação e a abrangência das informações coletadas no objeto, os cinco modelos aqui analisados propõem a busca de informações complementares em documentos secundários, como bibliográficos e arquivísticos. No entanto, cabe ressaltar que em Prown (1982) e em Batchelor (1994) essa proposta não é explícita, cabendo ao pesquisador inferir a importância da consulta em outras fontes a partir da necessidade de certificação das informações coletadas durante a aplicação do método.

\subsubsection{Níveis ou Camadas de Informação e Produtos}

A pesquisa também analisou os níveis de informação e os produtos propostos pelos autores dos modelos.

A análise dos níveis ou camadas de informação teve como parâmetro o esquema proposto por Peter van Mensch (1986). Profissional de museus e professor do curso de museus da Reinwardt Academy, Mensch faz parte do Comitê Internacional para a Museologia (ICOFOM) do Conselho Internacional de Museus (ICOM) e desenvolveu um esquema que identifica os níveis informacionais dos objetos.

Em uma primeira instância o valor de um objeto é determinado pela suas propriedades materiais [...]. 'Hardware' (informação intrínseca) e 'sofware' [sic] (documentação e informação contextual) juntos geram o 'testemunho' de um objeto. (MENSCH, 1986, p. 36, tradução nossa) $)^{88}$

\footnotetext{
88 In the first instance the value of an object is determined by its material properties. (...). 'Hardware' (intrinsic information) and 'sofware' [sic] (documentation and contextual information) together make an object 'testemony'.
} 
O que o autor chama de hardware e software, conforme já explicado na Fundamentação Teórica, são os níveis de informação dos objetos, também conhecidos como informação intrínseca e extrínseca (MENSCH, 1986; FERREZ, 1994), do objeto e sobre o objeto (LIMA, D., 2003), ou ainda dados sintáticos e semânticos. (SOUZA, 2009).

A importância da análise do nível de tratamento informacional nos modelos de estudo de objeto propostos pelos autores se justifica na profundidade dos dados levantados e no papel que os modelos devem exercer como ferramentas para os processos de Gestão ou Gerenciamento do Acervo, em especial no trablaho curatorial, de pesquisa e de documentação.

Quadro 16 - Dados Coletados - Camada de Informação

\begin{tabular}{|l|l|}
\hline \multicolumn{1}{|c|}{ MODELO } & \multicolumn{1}{c|}{ DADOS COLETADOS } \\
\hline C. Montgomery & Informações intrínsecas e extrínsecas. \\
\hline E. M. Fleming & Informações intrínsecas e extrínsecas. \\
\hline J. Prown & Informações intrínsecas e extrínsecas. \\
\hline R. Elliot & Informações intrínsecas e extrínsecas. \\
\hline S. Pearce & Informações intrínsecas e extrínsecas. \\
\hline R. Batchelor & Informações intrínsecas e extrínsecas. \\
\hline
\end{tabular}

Montgomery (1999), Pearce (1994) e R. Elliot (1994), em seus modelos, propões a identificação e estudos de dados que correspondem às informações intrínsecas e extrínsecas dos objetos.

Fleming (1974) e Prown (1982) também identificam essas duas categorias de informações. No entanto, os autores propõe considerações hipotéticas e subjetivas em seus estudo, o que fragiliza a aplicação desses modelos em contexto museológico, dada a importância das ações de gestão do acervo, nas quais os estudos exercerão papel de ferramenta. 
Já Batchelor (1994) apresentou um estudo mais focado nas informações extrínsecas, mesmo tendo em sua proposta a coleta de informações a respeito de material, manufatura e características estéticas. No entanto, o levantamento desses dados não se justifica pela importância de sua identificação, e sim como meios para interpretação dos dados extrínsecos do objeto.

No que diz respeito aos produtos propostos pelos autores, foram levantados os seguintes dados:

Quadro 17 - Dados Coletados - Produtos

\begin{tabular}{|l|l|}
\hline \multicolumn{1}{|c|}{ MODELo } & \multicolumn{1}{c|}{ DADOS ColetADOS } \\
\hline C. Montgomery & Não propõe nenhum produto específico. \\
\hline E. M. Fleming & Não propõe nenhum produto específico. \\
\hline J. Prown & Não propõe nenhum produto específico. \\
\hline R. Elliot . & $\begin{array}{l}\text { R. Elliot afirmam que o trabalho pode ser feito de forma } \\
\text { mental ou escrita. }\end{array}$ \\
\hline S. Pearce & Não propõe nenhum produto específico. \\
\hline R. Batchelor & Não propõe nenhum produto específico. \\
\hline
\end{tabular}

A grande maioria dos modelos, conforme é possível verificar no quadro acima, não propõe a elaboração de nenhum produto específico como resultado da aplicação da metodologia em um objeto.

A exceção é o modelo de R. Elliot (1994) que indica a possibilidade de elaborar o estudo do objeto de forma descritiva, elaborando dossiês para os itens da coleção. Esse dado vai de encontro ao proposto pelos órgãos normativos que se debruçam sobre as práticas de Documentação em Museus que indicam a criação de portefólios para cada ítem da coleção. 


\subsubsection{Aplicabilidade dos Modelos para Patrimônio de C\&T Musealizado}

A análise dos seis modelos de estudo do objeto desenvolvida por essa pesquisa teve como principal objetivo identificar qual dessas metodologias é a mais adequada para o tratamento informacional de acervos científicos. De forma prática, a identificação de um modelo para essa tipologia de coleção responderá ao objetivo geral proposto pela pesquisa de apontar ferramenta para a gestão da coleção telegráfica do Museu Correios - em especial nas atividades da Documentação. Cabe ressaltar que os modelos analisados na pesquisa foram desenvolvidos por autores de diversas áreas do conhecimento e referendados por Susan Pearce (1989; 1992; 1994) para a utilização em contexto museológico, em especial no âmbito da análise das coleções.

O primeiro modelo analisado, o de Charles Montgomery (1999), foi desenvolvido a partir das Artes Plásticas, e se estebeleceu como o resultado de exercícios realizados por alunos universitários que se debruçaram sobre a análise de objetos de Artes Plásticas e Aplicadas. O modelo não apresentou metodologia passível de aplicação em coleções científicas por propor o estudo do objeto a partir de quatorze pontos de análise, por vezes exclusivos do campo de origem do modelo.

Os modelos de Fleming (1974) e de Prown (1982), apesar de terem sido desenvolvidos em contexto museológico - ambos em museus artísticos - se apresentaram passíveis de serem aplicados em museus de ciência e tecnologia, principalmente pelo fato de, mesmo tendo como foco os aspectos estéticos e formais do objeto, orientar o estudo para questões de manufatura, utilização e atribuição de valores.

No entanto, as metodologias desenvolvidas pelos dois autores ainda apresentam um grau de subjetividade que impossibilita sua aplicação no âmbito da Gestão das Coleções, em especial da Documentação em Museus, foco desse trabalho.

Batchelor (1994), apesar de ter desenvolvido o seu modelo a partir da demanda de um museu de tecnologia, de apresentar um proposta ligada ao desenvolvimento do design e da técnica, e de trazer inovações ao estudo do objeto - como a análise das questões mercadológicas - propõe um estudo a partir do 
levantamento de informações pela observação. Assim, os dados levantados pelo autor se apresentam subjetivos, principalmente pela falta de um fase de certificação profissional das informações coletadas.

Outro aspecto que impossibilita a aplicação do modelo de Batchelor (1994) é o foco do modelo nas informações extrínsecas. Mesmo que o autor indique a identificação das informações intrínsecas, no modelo elas são utilizadas para interpretar as informações extrínsecas, e não como dado relevante da pesquisa.

Já os modelos desenvolvidos por R. Elliot (1994) e Pearce (1994) apresentaram aplicabilidade em museus de ciência e tecnologia, porém com alguns pontos em comum e outros divergentes.

Apesar de se originarem da mesma fonte - o modelo de Fleming (1974) - as metodologias e os esquemas propostos pelos autores são diferentes, no entanto complementares. Ambos apresentam terminologia mais estruturada que a do modelo-base, possibilitando trabalho com menor grau de ambiguidade e ruído na informação

O grupo de R. Elliot (1994), no entanto, se sobressai ao propor a certificação das informações por participação de profissionais das áreas referentes às coleções e apresentar esquema que possibilite um estudo mais dinâmico, uma vez que para chegar ao modelo final, foram realizadas diversas aplicações a fim de verificar erros e inconsistências ao modelo. Outro ponto importante do modelo proposto por R. Elliot é a utilização de gramáticas e terminologias específicas, o que dialoga de forma direta com as questões da linguagem documentária e de especialidade necessárias às práticas documentais.

Sendo assim, a pesquisa resultou na fusão dos dois modelos - R. Elliot e S. Pearce - propondo uma nova metodologia passível de aplicação em museu de ciência e tecnologia.

\subsection{Modelo Proposto pela Pesquisa}

O modelo proposto pela pesquisa, como dito anteriormente, teve como base as metodologias propostas por R. Elliot (1994) e Susan Pearce (1994), e tem como objetivo responder a demanda dos museus de ciência e tecnologia no que tange a 
existência de uma ferramenta que auxilie essas instituições na pesquisa e gerenciamento de suas coleções.

O modelo de R. Elliot (1994) foi tomado como base para o desenvolvimento do esquema metodológico aqui proposto. No entanto, na composição final, é possível perceber a interação com o modelo de Pearce (1994).

Figura 36 - Modelo final proposto na pesquisa

\begin{tabular}{|c|c|c|c|c|}
\hline & $\begin{array}{l}\text { Aspecto } \\
\text { Físico }\end{array}$ & $\begin{array}{c}\text { Material } \\
\text { Construção }\end{array}$ & $\begin{array}{l}\text { Procedência } \\
\text { Meio Ambiente }\end{array}$ & $\begin{array}{l}\text { Função } \\
\text { Histórico }\end{array}$ \\
\hline $\begin{array}{l}\text { Passo 01: } \\
\text { Dados Observáveis } \\
\text { (Grupo A) }\end{array}$ & & & & \\
\hline $\begin{array}{l}\text { Passo 02: } \\
\text { Dados } \\
\text { Complementares } \\
\text { (Grupo B) }\end{array}$ & & & & \\
\hline $\begin{array}{l}\text { Passo 03: } \\
\text { Dados } \\
\text { Comparativos } \\
\text { (Grupo C) }\end{array}$ & & & & \\
\hline
\end{tabular}

Fonte: adaptado de Elliot et al., 1994)

O modelo apresenta metodologia baseada em quatro características do objeto - Aspecto Físico, Material/Construção, Procedência/Meio Ambiente e Função/Histórico - que serão analisadas em três passos - Dados observáveis, Dados complementares e Dados comparativos.

De cada característica do objeto serão detalhadas informações em três fases: passo 01, passo 02 e passo 03, acima descritos. Ou seja, o Aspecto Físico do objeto será analisado a partir da observação, da comparação e de dados complementares, assim como o Material/Construção, e assim suscessivamente. Ao fim dessa análise, com todas as informações coletadas e certificadas, o objeto poderá ser valorado e interpretado.

Vale ressaltar que, a terminologia e a nomenclatura utilizada para a definição das categorias de informação e dos passos acima descritos foram adaptadas dos modelos-base para a metodologia proposta na pesquisa, conforme é possível 
verificar na análise dos modelos de R. Elliot (1994) e Pearce (1994), nos pontos 4.2.4. e 4.2.5. desta dissertação.

O modelo aqui proposto foi desenvolvido a partir da fusão dos modelos-base: os três passos propostos por R. Elliot ${ }^{89}$ e as oito ações propostas por Pearce, conforme verificado no quadro seguinte. Vale ressaltar que a escolha por essa fusão é justificada pela eficácia prevista nos dois modelos, buscando eliminar os pontos de fraqueza identificados na análise comparativa realizada nessa pesquisa.

Quadro 18 - Ações previstas no modelo

\begin{tabular}{|c|c|}
\hline PASSOS & AÇÕEs PREVIStas \\
\hline Passo 01 - Dados observáveis & $\begin{array}{l}\text { Análise das características físicas, } \\
\text { descrição, técnica, registros relevantes } \\
\text { (fotografia, desenho, entre outros). Como o } \\
\text { nome explicita, dados coletados a partir da } \\
\text { observação. }\end{array}$ \\
\hline Passo 02 - Dados complementares & $\begin{array}{l}\text { Datação, técnica, pesquisa documentária } \\
\text { relevante (referência cruzada); Registros in } \\
\text { loco e outros tipos de pesquisa; Paisagem e } \\
\text { estudo do meio ambiente de criação e uso } \\
\text { do objeto; Sistema filosófico dos envolvidos } \\
\text { com o objeto; Soma de estudo prévio, corpo } \\
\text { de conhecimento cultural e as técnicas } \\
\text { analíticas. }\end{array}$ \\
\hline Passo 03 - Dados comparativos & $\begin{array}{lcr}\text { Comparação } & \text { com outros } & \text { artefatos e } \\
\text { amostras } & \text { buscando } & \text { identificar } \\
\text { características } & \text { específicas } & \text { e grupos } \\
\text { tipológicos. } & & \end{array}$ \\
\hline
\end{tabular}

${ }^{89}$ No modelo original de R. Elliot eram quatro passos propostos. O último passo, valoração, foi fundido com o passo 02. 
Os passos e ações aqui propostos possibilitam a coleta dos dados para preenchimento de fichas de informação do objeto, em especial as fichas elaboradas a partir dos documentos desenvolvido pelo CIDOC e pela Collections Trust, órgãos máximos reguladores da atividade documental em contexto museológico, e usados como parâmetros para análise da ficha do Museu Correios na primeira fase dessa pesquisa.

É possível identificar, também, que a metodologia aqui proposta contempla os dois níveis de informação definidas por Mensch (1986). A coluna de Aspecto Físico corresponde às informações intrínsecas, enquanto as outras três colunas respondem às demandas extrínsecas ao objeto.

Uma vez que as informações coletadas nos processos de Documentação de coleções musealizadas devem ser as mais completas e certificadas, a metodologia proposta pela pesquisa prevê a utilização de dados de fontes secundárias de informação - ou seja, outros tipos de documentos como bibliográficos e arquivísticos - referência cruzada - e a participação de profissionais nas áreas que respondem pelo acervo - no caso da coleção telegráfica, a participação de engenheiros elétricos ou outros técnicos em eletricidade e em comunicação.

Cabe ressaltar que esse modelo de estudo de objeto se configura como ferramenta para as atividades de gerenciamento de coleções, extrapolando os limites da Documentação em Museus, se fazendo importante para as outras atividades, como a curadoria em exposições.

\subsection{Aplicação do Modelo Proposto em uma Peça da Coleção Telegráfica}

De forma a exemplificar o trabalho a ser desenvolvido no estudo de objetos de C\&T, bem como buscando certificar o resultado desse trabalho, optou-se por aplicar a metodologia proposta na pesquisa em um objeto da coleção telegráfica do Museu Correios.

O objeto escolhido para análise foi o aparelho telegráfico do tipo Bréguet, dada sua importância para a coleção do Museu Correios. Esse aparelho fez parte das duas exposições de longa duração montadas com o acervo dos Correios, desde a reabertura do museu em 2012. Além do seu aspecto estético, esse aparelho é de 
importância ímpar para a história telegráfica nacional: esse aparelho, que apresenta somente o terminal transmissor de mensagens, foi utilizado pelo Barão de Capanema nos testes realizados a pedido do, então, Ministro da Justiça, Eusébio de Queiroz, para instalação da telegrafia elétrica no Brasil. Em todo território nacional existem dois exemplares desse aparelho, ambos sob a tutela do Museu Correios.

Figura 37 - Telégrafo Bréguet

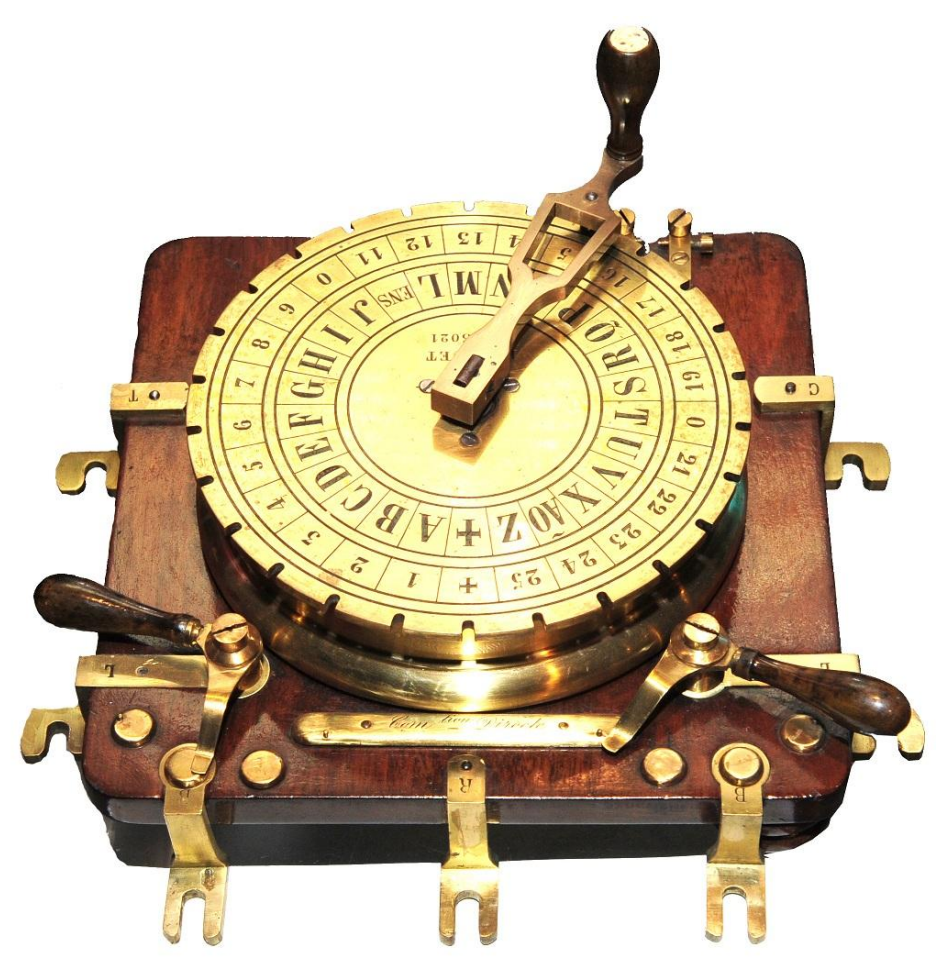

Foto: Jair Xavier / Acervo Museu Correios

O primeiro passo, conforme a metodologia proposta no ponto anterior, diz respeito aos Dados Observáveis. Dessa forma, o quadro a seguir apresenta os dados levantados das quatro características do objeto que compõem a modelo proposto (Aspecto Físico, Material/Construção, Procedência/Meio Ambiente e Funlçao/Histórico).

Quadro 19 - Dados Observáveis

\begin{tabular}{|l|l|}
\hline \multicolumn{1}{|c|}{ Características } & \multicolumn{1}{c|}{ Dados Coletados } \\
\hline \multirow{2}{*}{ Aspecto Físico } & $\begin{array}{l}\text { Composto de: um disco de metal, de 16cm de diâmetro, } \\
\text { com entalhes na periferia. Sobre ele estão gravados letras } \\
\text { e números dispostos em círculos concêntricos; uma } \\
\text { manivela que se move sobre o círculo. }\end{array}$ \\
\hline
\end{tabular}


(continuação do quadro 19)

\begin{tabular}{|c|c|}
\hline $\begin{array}{l}\text { Aspecto Físico } \\
\text { (continuação) }\end{array}$ & $\begin{array}{l}\text { Possui um dente que se encaixa nos entalhes; chaves } \\
\text { comutadoras e } 7 \text { saídas para a ligação do aparelho; Base } \\
\text { de madeira, quadrangular, de } 21,5 \mathrm{~cm} \times 21,5 \mathrm{~cm} \text {, com } \\
\text { ângulos abaulados e quatro pês em madeira e encaixados } \\
\text { na parte inferior da base, nos quatro cantos. O Museu } \\
\text { Correios não possui, atualmente, dados referentes ao } \\
\text { peso do objeto } \\
\text { Sobre o disco de metal é possível ver as inscrições } \\
\text { "BREGUET No } 43021 \text { ". Além disso é possível verificar nos } \\
\text { parafusos da base de madeira as letras B, C, L, R e T. } \\
\text { Em perfeito estado de conservação, sem marcas de } \\
\text { utilização. }\end{array}$ \\
\hline Material - Construção & Madeira envernizada e metal fundido. \\
\hline Procedência - Meio Ambiente & $\begin{array}{l}\text { Sobre o disco de metal é possível ver as inscrições } \\
\text { "BREGUET № } 43021 \text { ". Além disso é possível verificar nos } \\
\text { parafusos da base de madeira as letras B, R, L, T e C. No } \\
\text { círculo de metal é possível verificar gravados letras, } \\
\text { símbolos e números dispostos em círculos concêntricos. }\end{array}$ \\
\hline Função - Histórico & Aparelho telegráfico - módulo transmissor. \\
\hline
\end{tabular}

A segunda parte da metodologia proposta prevê a coleta de dados complementares. Nessa fase faz-se imprescindível a participação de profissionais de áreas específicas, no caso da coleção telegráfica de engenheiros de telecomunicação e elétricos, e a utilização de outras tipologias de documentos, como os bibliográficos e arquivísticos. Outros dados complementares devem ser coletados a partir do resultado de exames feitos no objeto como raios-x, datações e identificações específicas de material.

Cabe lembrar que a vida social do objeto não termina quando de sua musealização, cabendo ao museólogo responsável pela catalogação dos objetos a inclusão dos dados referentes à vida pós-musealização do objeto, como participações em exposições e publicações. 
Quadro 20 - Dados Complementares

\begin{tabular}{|c|c|}
\hline CARACTERÍSTICAS & DAdOS COLETADOS \\
\hline Aspecto Físico & $\begin{array}{l}\text { O Bréguet não apresenta numero de registro marcada } \\
\text { diretamente sobre a peça. No entanto, uma etiqueta foi } \\
\text { afixada no objeto com numeração } 001 / 76 \text {. Atualmente se } \\
\text { encontra na exposição "Os sinais e as coisas: das } \\
\text { fogueiras à internet", desde julho de } 2014 \text {. No entanto, sua } \\
\text { localização usual é RT-01. As imagens que constam na } \\
\text { ficha catalográfica foram tiradas na década de 1970. No } \\
\text { entanto, o funcionário Jair Xavier, fotógrafo profissional, } \\
\text { fotografou o Bréguet e anexou à ficha catalográfica do } \\
\text { objeto, sem números de referência. As inscriçães } \\
\text { identificadas no aparelho dizem respeito ao fabricante } \\
\text { (Maison Bréguet) e número de série (43021). } \\
\text { Não há registro para classificação do objeto no Thesaurus } \\
\text { de Acervos Museológicos. No entanto, dentro do } \\
\text { Thesaurus desenvolvido pelo Museu de Astronomia e } \\
\text { Ciências Afins ele é classificado como Instrumento de } \\
\text { Demonstração e Estudo-Operativo, na subcategoria } \\
\text { Telégrafo, termo específico Telégrafo de Bréguet. }\end{array}$ \\
\hline Material - Construção & $\begin{array}{l}\text { No caso do aparelho Bréguet alguns testes químicos } \\
\text { possibilitariam a identificação do material e de datação. }\end{array}$ \\
\hline Procedência - Meio Ambiente & $\begin{array}{l}\text { Os aparelhos Bréguet foram importados da França e } \\
\text { produzidos pela Maison Bréguet. } \\
\text { Não se tem dados concretos de como o aparelho Bréguet } \\
\text { chegou aos Correios. Sabe-se que já fazia parte do acervo } \\
\text { histórico da Empresa quando da exposição retrospectiva } \\
\text { de } 1965 \text { e da instalação do Museu Postal e Telegráfico, na } \\
\text { década de 1980. Não há indícios de sua presença no } \\
\text { acervo do Museu Telegráfico do século XIX. }\end{array}$ \\
\hline
\end{tabular}

(continua...) 
(continuação do quadro 20)

\begin{tabular}{|c|c|}
\hline Função - Histórico & 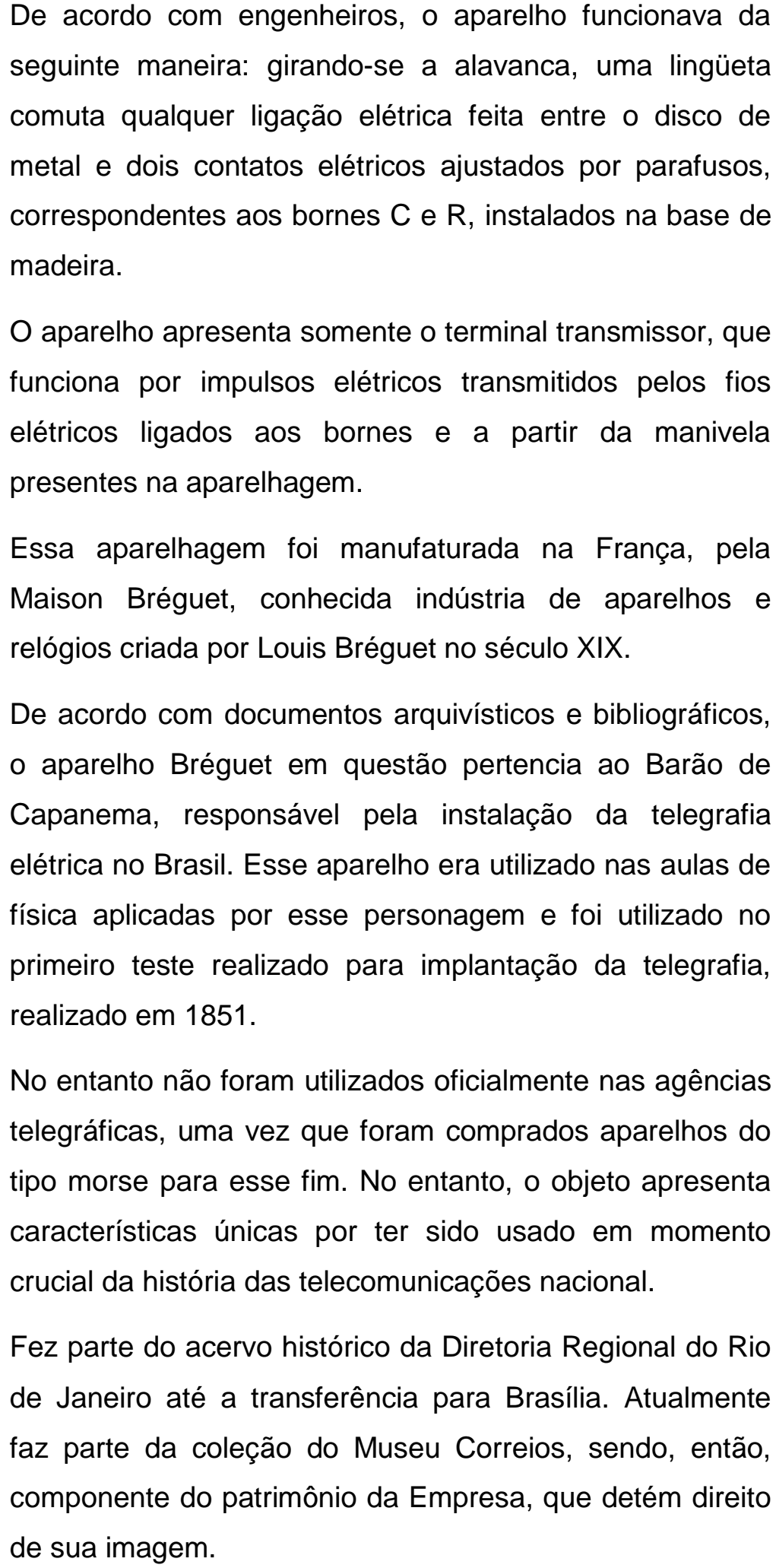 \\
\hline
\end{tabular}

(continua...) 
(continuação do quadro 20)

\begin{tabular}{|l|l|}
\hline \multirow{2}{*}{$\begin{array}{l}\text { Função - Histórico } \\
\text { (continuação) }\end{array}$} & $\begin{array}{l}\text { Participou da exposição retrospectiva de 1965, fez parte } \\
\text { da exposição permanente do Museu Postal e Telegráfico } \\
\text { nas décadas de } 1980 \text { e 1990. Com a reabertura do } \\
\text { Museu, participou das exposição "Correios: um diálogo } \\
\text { com Vilém Flusser". Atualmente se encontra na exposição } \\
\text { "Os sinais e as coisas: das fogueiras à internet", no quinto } \\
\text { andar do Museu Correios. }\end{array}$ \\
\hline
\end{tabular}

Cabe ressaltar que referências bibliográficas, arquivísticas e de eventos e publicações, bem como dados referentes à baixa patrimonial, quando ocorrer, entram nesse ponto do estudo do objeto.

Após a coleta dos dados complementares será possível preencher fichas catalográficas e ter um amplo espectro informacional do objeto.

No entanto, a terceira parte da metodologia proposta pela pesquisa prevê a coleta de dado a partir da comparação. Esse terceiro passo possibilita a coleta de dados que identifiquem alguns aspectos relacionados à evolução das tecnologias, ou mesmo questões a respeito da padronização na construção dos aparelhos.

No caso do Bréguet pode-se estabelecer comparação com outro de semelhante modelo e com outros tipos de aparelhos telegráficos de forma a identificar características próprias dessa tipologia de equipamento.

Quadro 21 - Dados comparativos

\begin{tabular}{|l|l|}
\hline \multicolumn{1}{|c|}{ Características } & \multicolumn{1}{c|}{ Dados Coletados } \\
\hline \multirow{3}{*}{ Aspecto Físico } & $\begin{array}{l}\text { Entre os dois aparelhos Bréguet não há poucas diferenças } \\
\text { físicas - limitadas ao número de série e no estado de } \\
\text { conservação. } \\
\text { Já entre o aparelho Morse e o aparelho Baudot é possível } \\
\text { verificar que, diferentemente do aparelho Bréguet, os } \\
\text { primeiros apresentam em um mesmo conjunto, o receptor } \\
\text { e o transmissor. Ou seja, o telégrafo Morse e o Baudot } \\
\text { apresentam suas estruturas completas. }\end{array}$ \\
\hline
\end{tabular}


(continuação do quadro 21)

\begin{tabular}{|c|c|}
\hline $\begin{array}{l}\text { Aspecto Físico } \\
\text { (continuação) }\end{array}$ & $\begin{array}{l}\text { No que diz respeito à sua configuração física, os três } \\
\text { aparelhos apresentam design extremamente diferentes, } \\
\text { cada um com sua especificidade e tecnologias. }\end{array}$ \\
\hline Material - Construção & $\begin{array}{l}\text { Entre os Bréguets não há diferença de material. } \\
\text { Comparativamente, os aparelhos Morse e Bréguet foram } \\
\text { construídos com o mesmo material - madeira e metal - } \\
\text { havendo diferenças, somente, no tipo de madeira utilizada } \\
\text { no suporte do aparelho Morse. } \\
\text { No entanto, em comparação com o Baudot, é possível } \\
\text { verificar mudança. Passa a ser utilizado resina sintética - } \\
\text { baquelite. } \\
\text { No entanto é possível verificar continuidade no que diz } \\
\text { respeito à manufatura dos aparelhos, mesmo com as } \\
\text { mudanças e adequações tecnológicas. }\end{array}$ \\
\hline Procedência - Meio Ambiente & $\begin{array}{l}\text { Os Bréguets e Baudots são de origem francesa e os } \\
\text { aparelhos morses americanos (fabricados pela Siemens), } \\
\text { todos utilizados em agências telegráficas em todo o Brasil. } \\
\text { Os aparelhos que hoje compõem a coleção telegráfica } \\
\text { apresentam diversas procedências, sendo a mais comum } \\
\text { o acervo histórico do Departamento de Correios e } \\
\text { Telégrafos, do Rio de Janeiro. }\end{array}$ \\
\hline Função - Histórico & $\begin{array}{l}\text { Os aparelhos do tipo Bréguet, Morse e Baudot possuem a } \\
\text { mesma funcionalidade tecnológica: transmissores e } \\
\text { receptores de mensagens telegráficas. No entanto, } \\
\text { existem diferenças quanto ao uso e desempenho dos } \\
\text { aparelhos. O Bréguet envia mensagens caractere a } \\
\text { caractere por meio da manivela presente no aparelho. O } \\
\text { aparelho Morse funciona a partir da transmissão de } \\
\text { mensagens por meio da interrupção da corrente elétrica, } \\
\text { codificada em um sistema binário de pontos e traços, o } \\
\text { código Morse. }\end{array}$ \\
\hline
\end{tabular}


(continuação do quadro 21)

\begin{tabular}{|l|l|}
\hline \multirow{1}{*}{$\begin{array}{l}\text { Função - Histórico } \\
\text { (continuação) }\end{array}$} & $\begin{array}{l}\text { E o Baudot, por sua vez, acompanhou o desenvolvimento } \\
\text { tecnológico e apresenta possibilidade de ligação de mais } \\
\text { de uma linha em um mesmo aparelho, e transmissão de } \\
\text { mensagens baseado em cinco teclas que, combinadas, } \\
\text { representam caracteres. Por ter cinco teclas, o sistema } \\
\text { não se apresenta mais de configuração binária, } \\
\text { possibilitando maior quantidade de combinações e, } \\
\text { consequentemente, de caracteres. } \\
\text { Sua utilização, apesar de apresentar a mesma } \\
\text { funcionalidade, também se apresentam distintas, uma vez } \\
\text { que o aparelho Baudot possibilita ligação de mais de uma } \\
\text { linha simultânea por aparelho. }\end{array}$ \\
\hline
\end{tabular}

A aplicação do modelo aqui proposto teve como função a certificação de sua metodologia, bem como apresentar o trabalho porposto ao Museu Correios. No entanto, as informações aqui apresentadas não se fazem definitivas, devendo ser complementadas com posteriores pesquisas, como por exemplo as referências bibliográficas $^{90}$ e arquivísticas, e atualizações no status do objeto dentro da instituição, e com as futuras atividades empreendidas pelo Museu.

90 O CEDOC do Museu Correios possui amplas coleções de documentos e publicações da área postal e telegráfica, como as revistas Correio Filatélico (COFI), Boletins Telegráfica, revista Postal e Telegráfica, entre outros. Dessa forma, o modelo prevê o levantamento de todas as publicações e documentos arquivísticos onde o objeto estudado foi citado ou apresenta fotografia ilustrando o texto. Para essa dissertação não foi feito esse levantamento, uma vez que demandaria uma pesquisa mais aprofundada e que levaria mais tempo para sua finalização. No entanto, foi ressaltada nesse trabalho a importância que essa pesquisa apresenta. 
Figura 38 - Telégrafo Bréguet (detalhe 01)

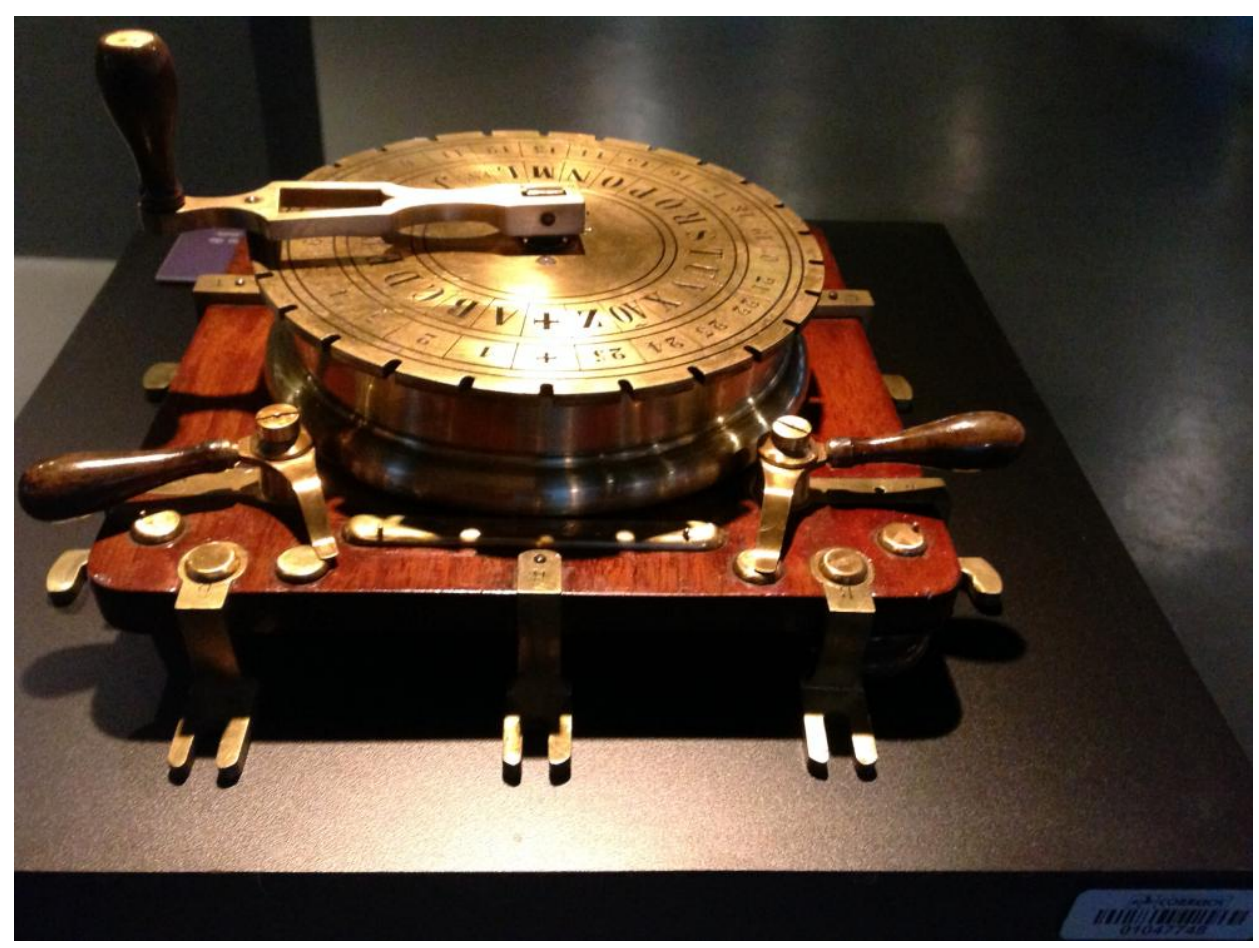

Foto: Bernardo Arribada - Acervo Museu Correios

Figura 39 - Telégrafo Bréguet (detalhe 02)

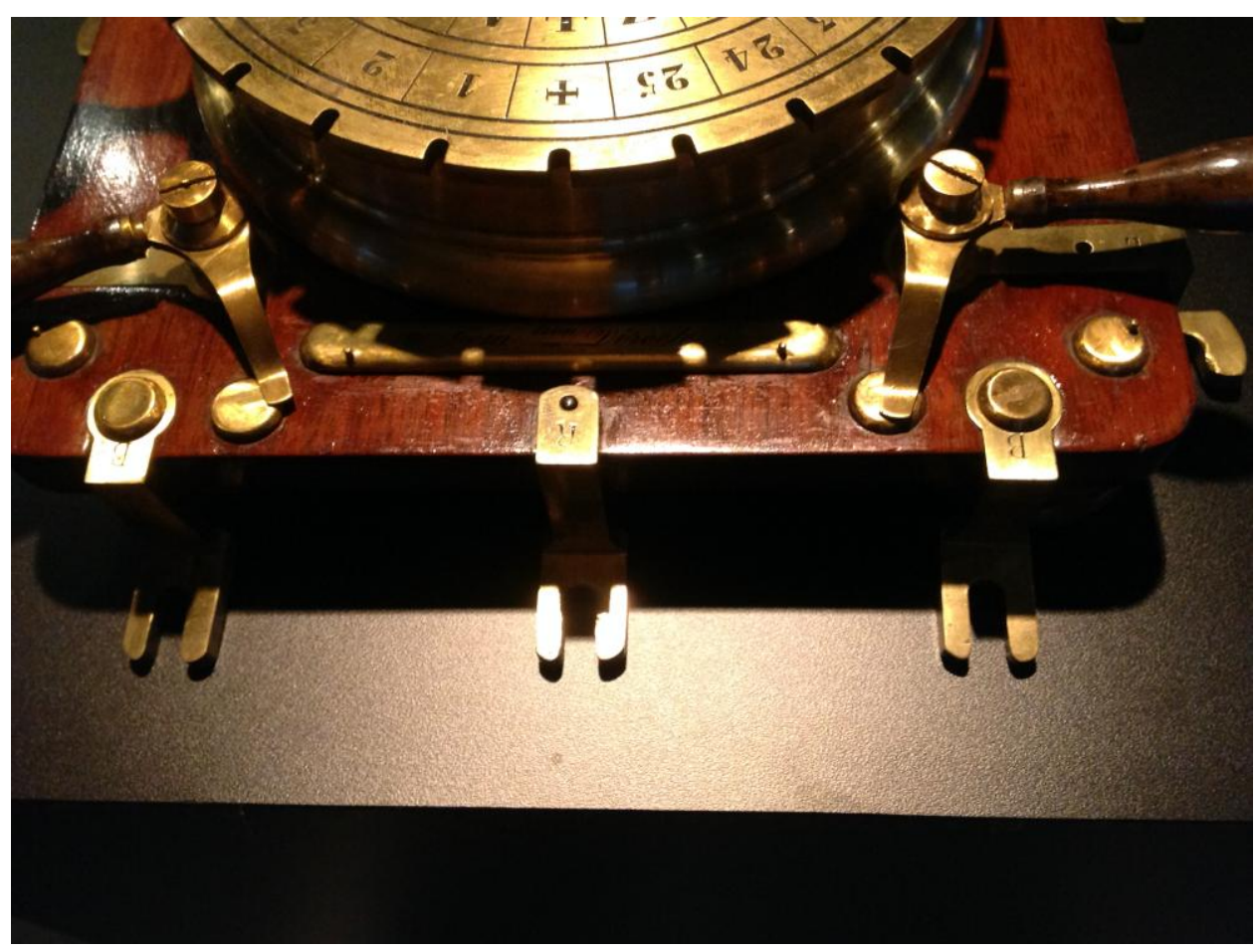

Foto: Bernardo Arribada - Acervo Museu Correios 
Figura 40 - Telégrafo Bréguet (detalhe 03)

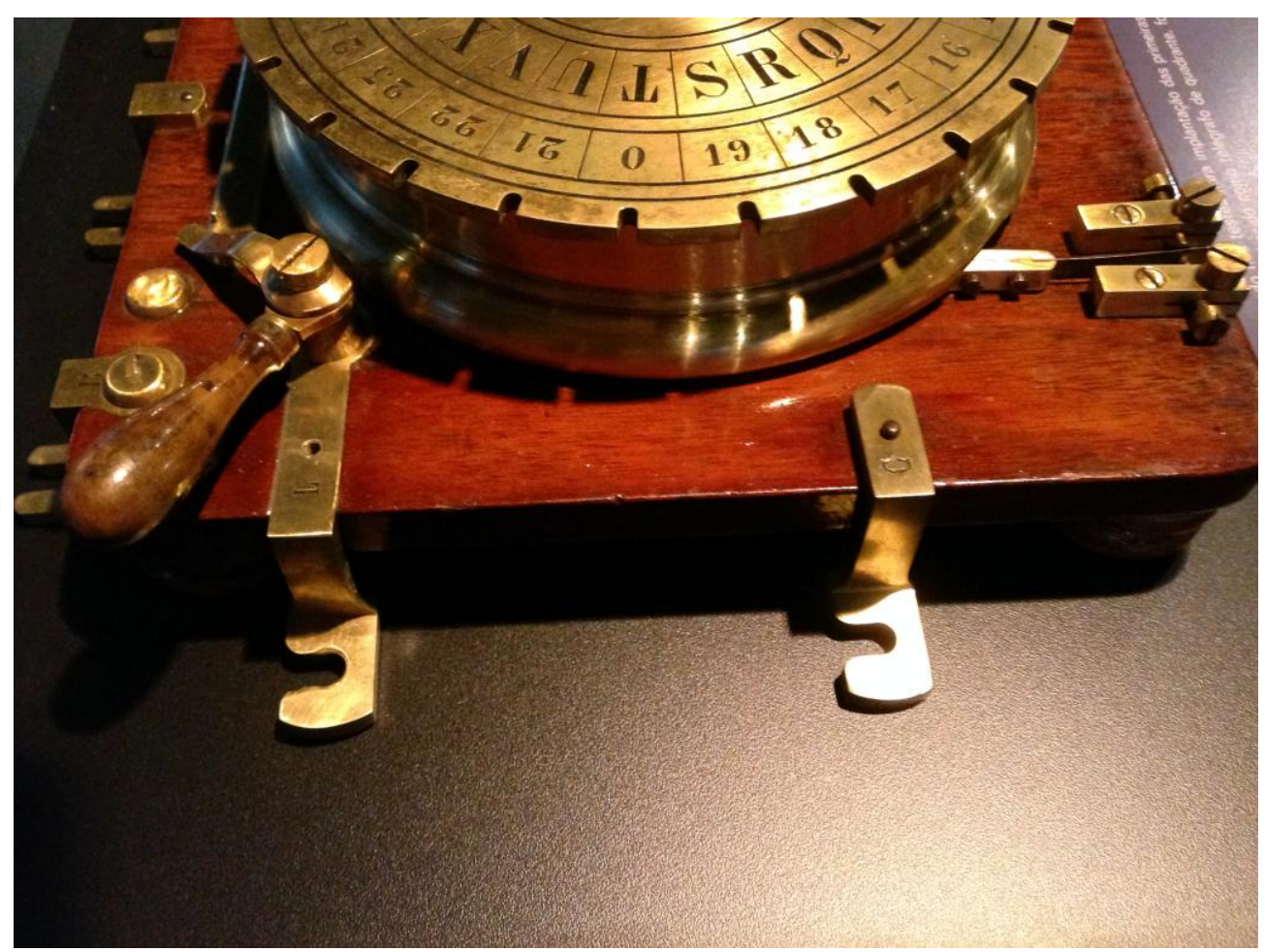

Foto: Bernardo Arribada - Acervo Museu Correios

Figura 41 - Telégrafo Bréguet (detalhe 04)

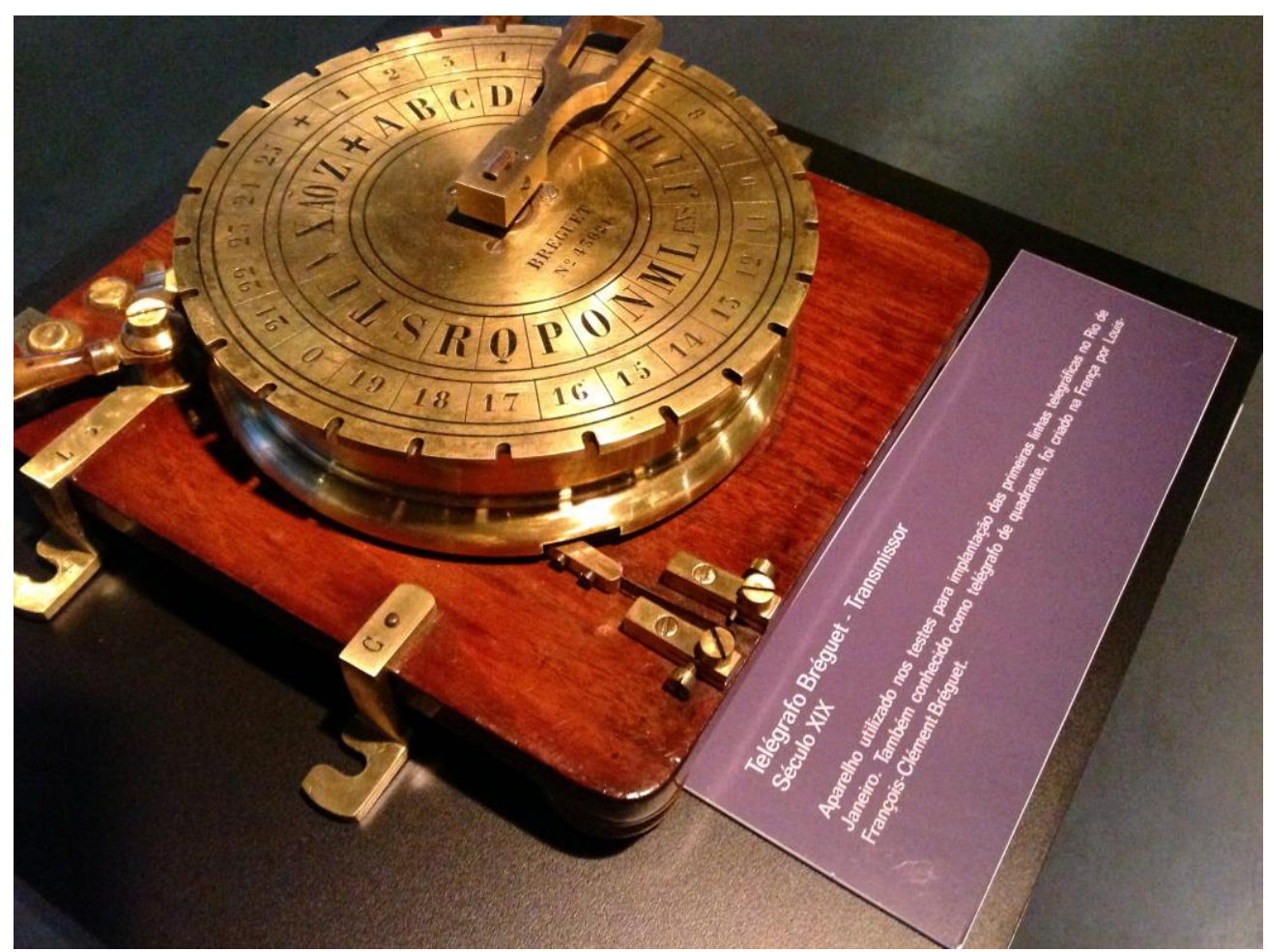

Foto: Bernardo Arribada - Acervo Museu Correios 
Figura 42 - Telégrafo Bréguet (detalhe 05)

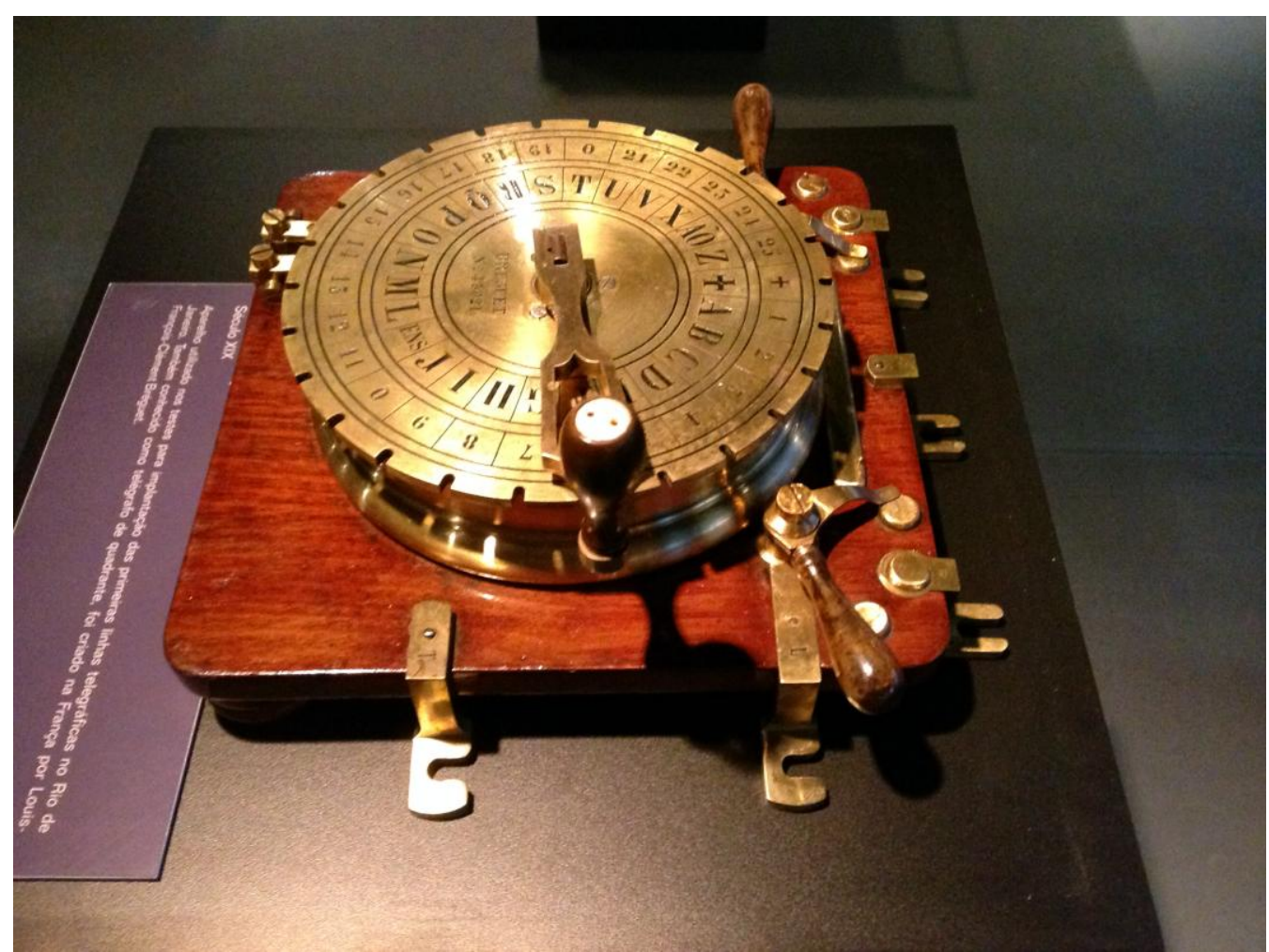

Foto: Bernardo Arribada - Acervo Museu Correios 


\section{Considerações Finais}

A Documentação em Museus, é conjunto de atividades essenciais aos museus, à medida em que atuam em pontos estratégicos para o bom funcionamento das instituições.

Os documentos originados das atividades de registro, catalogação, inventário e indexação atuam no âmbito da administração das coleções, na segurança e, principalmente, no aspecto comunicacional do Museu, como fonte para pesquisas e para o desenvolvimento de ações de comunicação - em especial exposições.

A pesquisa "Tratamento Informacional da Coleção Telegráfica do Museu Correios: análise sob a perspectiva científica, tecnológica e de cultura material" teve como objetivo geral identificar qual modelo de cultura material, desenvolvidos por profissionais que se debruçaram sobre as questões da Cultura Material e referendados para uso em instituições museológicas, é o mais adequado para o tratamento informacional da coleção telegráfica do Museu Correios.

Em contrapartida, esse objetivo buscou fortalecer a interdisciplinaridade entre a Museologia e a Ciência da Informação no que tange ao tratamento informacional dos documentos - objetos de museu -, bem como identificou subsídios para o gerenciamento de coleções de ciência e tecnologia - Patrimônio Científico Musealizado.

No primeiro momento, foi analisado o sistema de documentação do Museu Correios. Esse sistema, formado pela estrutura dos dados das fichas catalográficas, os procedimentos e a terminologia utilizada no processo documental, deve ter como eixo a normalização e padronização visando efetiva representação, recuperação e disseminação da informação. A análise teve como parâmetros, os documentos elaborados por órgãos normativos, internacionais e nacionais, buscando identificar adequação do sistema do Museu Correios à essas normas, criadas como diretrizes para as atividades museológicas.

Assim, foi verificado que, atualmente, o sistema do Museu Correios se encontra fora dos padrões estabelecidos por esses órgãos, havendo a necessidade de elaboração de normas institucionais para melhor direcionamento das atividades, buscando fortalecer a ação do Museu no que diz respeito ao seu papel de instituição 
de pesquisa e mantenedora de importante parcela do Patrimônio Científico e Cultural musealizado.

De forma mais explícita, sabe-se agora que, além de não haver normativa estabelecida para as atividades de análise de conteúdo das coleções museológicas, - Museu Correios não tem definido uma metodologia própria para o estudo dos objetos que compõem suas coleções, de forma a auxiliar nas questões de representação da informação - em outras palavras nas atividades de registro, catalogação, inventário e indexação, componentes da Documentação em Museus.

Tendo como foco o tratamento informacional, em especial a análise da informação dos objetos que compõem a coleção telegráfica, a pesquisa identificou metodologias específicas para estudo de objetos - os Estudo de Cultura Material elaboradas por profissionais de diversas áreas, como a Antropologia, a Arte e a História, e cuja aplicação em contexto museológico foi corroborada por Susan Pearce, professora do curso de museus da Leicester University.

O objetivo da pesquisa girou em torno de verificação da aplicação desses modelos em museus de ciência e tecnologia, uma vez que essas instituições, conforme pesquisadores da área afirmam, não apresentam normativas determinadas para as atividades de gestão de suas coleções, em especial da informação museológica.

Dos seis modelos analisados, verificou-se que todos os modelos apresentavam pontos positivos e negativos no que tange sua aplicação em museu de ciência e tecnologia, havendo a necessidade, então, de adequação desses modelos ao ambiente da pesquisa.

Assim, elaborou-se um modelo visando aplicação nessa tipologia de acervo. Uma vez que o Museu Correios apresenta uma coleção composta por exemplares de ciência e tecnologia, a pesquisa desenvolveu, então, ferramenta específica para o tratamento informacional dessa parcela do acervo da instituição.

No entanto, a pesquisa não se pretende definitiva, abrindo caminho para novas possibilidades de estudo e, principalmente, verificação de aplicação desse modelo para qualquer tipologia de acervo, possibilitando, assim, a delimitação de uma ferramenta para análise da informação museológica, independente da tipologia das coleções que compõem o Patrimônio Cultura musealizado. 


\subsection{Estudos Futuros}

Conforme verificado, os resultados da pesquisa em tela se configuram como uma linha de ação frente às demandas dos museus de ciência e tecnologia (C\&T) no que tange às metodologias para análise do objeto e desenvovlimento de ferramentas que auxiliem na gestão e uso de suas coleções.

Dessa forma, o estudo aqui desenvolvido abre novas possibilidades de pesquisa, como o mapeamento de metodologias para análise dos objetos em prática nos museus. Atualmente o Museu de Astronomia e Ciência Afins (MAST) é a principal instituição de pesquisa no campo das ciências, tendo, em seu corpo profissional, pesquisadores que se debruçam na temática.

Outra possibilidade inclui o mapeamento de outros modelos desenvolvidos por profissionais de diversas áreas e verificar a adequação desses novos modelos ao ambiente dos museus de C\&T, corroborando com essa pesquisa e trazendo novas ferramentas e possibilidades metodológicas para o tratamento da Informação em Museus.

E, por último, verifica-se uma necessidade imperativa de estudo acerca do tratamento informacional nessas unidades museológicas, uma vez que não existe unicidade na terminologia utilizada pelos museus, bem como da análise dos dados, representação e disseminação da informação. 


\section{Referências}

AHMED, J. U. Documentary research methods: new dimensions. Indus Journal of Management \& Social Sciences. 4(1). 2010. p.1-14.

ALBERTI, S. J. M. M. Objects and the museum. Isis. n. 96. 2005. p. 559-571.

ALMEIDA, C. A. F. O "colecionismo ilustrado" na gênese dos museus contemporâneos. Anais do Museu Histórico Nacional. v. XXXIII. 2001. p. 123-140.

ALVARES, L; ARAÚJO JUNIOR, R. H. Marcos históricos da ciência da informação: breve cronologia dos pioneiros, das obras clássicas e dos eventos fundamentais. TransInformação. Campinas. 22 (3). set/dez. 2010.

APPADURAI, A. Introdução: mercadorias e a política de valor. In: A vida social das coisas - As mercadorias sob uma perspectiva cultural. Niterói: EdUFF. 2008. p. 15-87.

BACA, M; COBURN, E; HUBBARD, S. Metadata and museum information. In: MARTY, P. F.; JONES, K. B. Museum Informatics. People, information, and technology in museums. New York. London: Routledge. 2008. p.107-128.

BAPTISTA, D. M.; ARAÚJO JR., Rogerio Henrique de; CARLAN, Eliana. Atributos dos Requisitos Funcionais para Registros Bibliográficos (FRBR). In: ROBREDO, J.; BRASCHER, M. (Orgs.). Passeios no bosque da informação: estudos sobre representação e organização da informação e do conhecimento. Brasília DF: IBICT, 2010. Capítulo 3 p. 6180. Disponível em: <http://repositorio.bce.unb.br/bitstream/10482/7975/1/ CAPITULO_EscopoAnaliselnformacao.pdf>. Acesso em: 11 fev. 2015

BATCHELOR, R. Not looking at kettles. In: PEARCE, S. Interpreting objects and collections. Londres. Nova York: Routledge. 1994. p.139-143

BAUDRILLARD, J. Senhas. 2.ed. Rio de Janeiro: Difel. 2007.

BECKOW, S. M. Culture, history, and artifact. In: SCHLERETH, T. Material culture studies in America. Lanham: Altamira Press. 1999. p114-123.

BERGENGREN, G. Vers um système d'information total. Museum. v. XXX (Musées et ordinateurs). n. 3-4. 1978. p.213-217

BERGERON, Y. Regard \& analyse. In: DESVALLÉES, A.; MAIRESSE, F. Dictionnaire encyclopédique de museologie. Paris : Armand Colin. 2011. p. 55-69.

BITTENCOURT, J. N. Cultura material, museus e história: algumas considerações sobre um debate que não é tão intenso quanto deveria ser. Revista Eletrônica Humanas. Rio de Janeiro. UFRJ. 1989. Disponível em: <http://www.ifcs.ufrj.br/humanas/0029.htm>. Acesso em: 26 jan. 2015.

Estudos de cultura material: um cruzamento necessário. In: OLIVEIRA, A. P. P. L.; OLIVEIRA, L. M. (Orgs.). Sendas da Museologia. Ouro Preto: UFOP. 2012. p. 123-130.

BRASIL. Lei 11.904, de 14 de janeiro de 2009. Disponível em: <http://www.planalto.gov.br/ccivil_03/_Ato2007-2010/2009/Lei/L11904.htm>. Acesso em: 12 jan. 2015. 
Decreto 8.124, de 13 de outubro de 2013. Disponível em: <http://www.planalto.gov.br/ccivil_03/_Ato2011-2014/2013/Decreto/D8124.htm>. Acesso em: 12 jan. 2015.

BRIET, S. Qu'est-ce que la documentation? Paris: EDIT - Éditions Documentaires, Industrielles et Techniques. 1951.

BRUNO, M. C. O. Estudos de cultura material e coleções museológicas: avanços, retrocessos e desafios. In: GRANATO, M.; RANGEL, M. Cultura Material e Patrimônio de Ciência e Tecnologia. Rio de Janeiro: Museu de Astronomia e Ciências Afins. 2009. p. 1425. Disponível em: <http://www.mast.br/livros/cultura_material_e_patrimonio_da_ciencia_ e_tecnologia.pdf>. Acesso em: 26 dez. 2015.

BUCKLAND, M. K. Information as thing. Journal of the American Society for Information Science. 42 (5). 1991a. p. 351-360 1991b.

Information and Information Systems. New York, Connecticut, London: Praeger.

What is "document". 1997. Disponível em: <http://people.ischool.berkeley.edu/ rbuckland/whatdoc.html>. Acesso em: 09 de fev. de 2015.

INTERNATIONAL COMMITTEE FOR DOCUMENTATION - CIDOC. International Guidelines for museum object information: the CIDOC information categories. 1995a. Disponível em: <http://www.cidoc-crm.org/docs/guide.htm>. Acesso m: 12 jan. 2015 1995b.

Developments in museum and cultural heritage information standards. 1993.

COUZINET, V. Le document: leçon d'histoire, leçon de méthode. Communication \& Langages. n. 140. Juin. 2004. p. 19-29.

CRESWELL, J. W. Research Design - Qualitative, quantitative and mixed methods approaches. 2. ed. USA: University of Nebraska, Lincoln. 2003.

DODEBEI, V. L. D. Tesauro: linguagem de representação da memória documentária. Niterói: Intertexto; Rio de Janeiro: Interciência, 2002. 119 p.

ELLIOT, R. et. al. Towards a material history methodology. In: PEARCE, S. Interpreting objects and collections. Londres. Nova York: Routledge. 1994. p.109-124

FERNÁNDEZ, L. A. Tipos y categorias de museos. In: Barcelona: Ediciones del Serbal. 4.ed. 2010. p. 107-147. Museologia y museografía. Usos, funciones y roles convencionales del museo. In: museografía. Barcelona: Ediciones del Serbal. 4.ed. 2010. p. 149-270. Museologia y

FERREZ, H. D. Documentação Museológica: Teoria para uma boa prática. In: Estudos Museológicos. IPHAN. Rio de Janeiro. 1994. p.65-74. (Caderno de Ensaios 2)

FERREZ, H. D.; BIANCHINI, M. H.; Thesaurus para acervo museológicos. Vol.1. Rio de Janeiro: Fundação Nacional Pró-Memória/SPHAN/MinC. 1987.

FLEMING, E. McClung. Artifact Study: a proposed model. Winterthur Portfolio. vol. 9. 1974. p. 153-173. 
FLICK, U. Introdução à Pesquisa Qualitativa. Porto Alegre: Artmed. 2009.

GETTY Research Institute. Art \& Architecture Thesaurus (AAT). 2015. Disponível em: $<$ http://www.getty.edu/research/tools/vocabularies/aat/index.html>. Acesso em: 04 dez. 2015.

The Getty Thesaurus of Geographic Names (TGN). 2015. Disponível em: <http://www.getty.edu/research/tools/vocabularies/tgn/index.html>. Acesso em: 04 dez. 2015.

. The Cultural Objects Name Authority (CONA). 2015. Disponível em: <http://www.getty.edu/research/tools/vocabularies/cona/index.html>. Acesso em: 04 dez. 2015.

The Union Listo of Artist Names (ULAN). 2015. Disponível em: <http://www.getty.edu/research/tools/vocabularies/ulan/index.html>. Acesso em: $04 \mathrm{dez}$. 2015.

GONÇALVES, J. R. S.. Teorias antropológicas e objetos materiais. In:

Antropologia dos Objetos: coleções, museus e patrimônios. Rio de Janeiro: IPHAN Instituto do Patrimônio Histórico e Artístico Nacional. 2007. p. 13-42. (Coleção Museu, Memória e Cidadania)

GRANATO, M. Panorama sobre o patrimônio da ciência e tecnologia no Brasil: objetos de C\&T. In: GRANATO, M.; RANGEL, M. Cultura Material e Patrimônio de Ciência e Tecnologia. Rio de Janeiro: Museu de Astronomia e Ciências Afins. 2009. p. 78-102. Disponível em: <http://www.mast.br/livros/cultura_material_e_patrimonio_da_ciencia_e_ tecnologia.pdf>. Acesso em: 26/12/2014.

As exposições e o uso de Acervos em Museus de Ciência e Tecnologia. In: MAGALHAES, A. M.; BEZERRA, R. Z.; BENCHETRIT, S. F. (Orgs.) Museus e Comunicação - Exposição como objeto de estudo. Rio de Janeiro: Museu Histórico Nacional. 2010. p.207-212.

GRANATO, M. SANTOS, C. P. dos. FURTADO, J. L. GOMES, L. P. Objetos de Ciência e Tecnologia como Fontes Documentais para a História das Ciência: resultados parciais. In: VIII ENANCIB - Encontro Nacional de Pesquisa em Ciência da Informação. Salvador. 28 a 31 de outubro de 2007. Trabalhos Apresentados. Salvador. 2007. n/p. Disponível em: <http://www.enancib.ppgci.ufba.br/artigos/DMP--035.pdf>. Acesso em: 22 jan. 15.

GRASSBY, R. Material culture and cultural history. Journal of Interdisciplinary History. v. 35. n. 4. 2005. p. 591-603.

HAGEDORN-SAUPE, M. Documentation Jigsaw - Documentation in the Museum World more than just documenting museum objects. In: 2008 ANNUAL CONFERENCE OF CIDOC. Papers... Atenas. 2008.

GUEDES, A. C. Museus, documentação e transmissão cultural. In: MAGALHAES, A. M.; BEZERRA, R. Z.; BENCHETRIT, S. F. (Orgs.) Museus e Comunicação: Exposição como objeto de estudo. Rio de Janeiro: Museu Histórico Nacional. 2010. p.207-212. 
INTERNATIONAL Council of Museums (ICOM). Code of Ethics for Museums. Buenos Aires, 1986. Barcelona, 2001. Seul, 2004. 2009. Disponível em: http://icom.museum/thevision/code-of-ethics/translations/. Acesso em 16 de setembro de 2014.

INTERNATIONAL Council of Museums (ICOM). African Museums Committee (AFRICOM). Normalisation des inventaires des collections en Afrique: manuel des normes. Disponível em: <http://archives.icom.museum/afridoc/light/welcome.html>. Acesso em: dezembro de 2015.

JULIEN, M-P.; ROSSELIN, C. La culture matérielle. Paris: La Découvert. 2005.

KOPYTOFF, I. A biografia cultural das coisas: A mercantilização como processo. In:

A vida social das coisas: as mercadorias sob uma perspectiva cultural. Niterói: $\overline{E d U F F}$. 2008. p. 89-121.

LE COADIC, Y-F. A ciência da informação. Brasília: Briquet de Lemos. 1998.

LE GOFF, J. História e memória. 3ª Ed. Campinas: UNICAMP. 1994.

LIMA, D. F. C. Ciência da informação, Museologia e fertilização interdisciplinar: Informação em Arte, um novo campo do saber. 2003. Tese (Doutorado em Ciência da Informação). IBICT/PPGCI-UFRJ/ECO. Rio de Janeiro. Orientadora: Lena Vania Ribeiro Pinheiro. 358fs.

Ciência da Informação e Museologia em tempo de conhecimento fronteiriço: aplicação ou interdisciplinaridade? In: IX Encontro Nacional de Pesquisa em Ciência da Informação (ENANCIB). São Paulo. Trabalhos Apresentados. São Paulo: USPUniversidade de São Paulo. 2008.

LIMA, D. F. C.; ARRIBADA, B. B. Museologia e linguagem de especialidade: discutindo documentação, catalogação, inventário e indexação. In: WORKSHOP ICOFOM-LAM 2008 Museologia como Campo Disciplinar. Documentos de Trabalho... 2008. Rio de Janeiro: Universidade Federal do Estado do Rio de Janeiro (UNIRIO), Programa de Pós-Graduação em Museologia e Patrimônio - UNIRIO / MAST (PPG-PMUS - UNIRIO/MAST). Não paginado.

LIMA, T. A. Cultura material: a dimensão concreta das relações sociais. Boletim do Museu Paraense Emílio Goeldi. Ciências Humanas. v. 6. n. 1. jan-abr. 2011. p. 11-23.

LOUREIRO, M. L. N. M. Notas sobre a construção do objeto musealizado como documento. Anais do Museu Histórico Nacional. vol. 44. 2012. p. 91-106.

LOUREIRO, M. L. N. M.; LOUREIRO, J. M. M.; SILVA, S. D. Museus, informação e cultura material: o desafio da interdisciplinaridade. In: IX Encontro Nacional de Pesquisa em Ciência da Informação (ENANCIB). São Paulo. Trabalhos Apresentados. São Paulo: USPUniversidade de São Paulo. 2008.

LUBAR, S. ; KINGERY, W. D. Introduction. In :

History from things: essays on material culture. Londres, Washington: Smithsonian Institution Press. 1993. p. viii-xvii.

MAIRESSE, F. Muséalisation : regard \& analyse. In: DESVALLÉES, A. ; MAIRESSE, F. Dictionnaire encyclopédique de museologie. Paris : Armand Colin. 2011. p. 252-269.

MAROEVIC, I. The museum object as historial source and document. In: INTERNATIONAL Committee for Museology (ICOFOM) International Symposium. 2006. Córdoba/Argentina. 
Proceedings. Córdoba: Museo Nacional Estancia Jesuitica de Alta Gracia y Casa del Virrey Liniers e Universidad Nacional de Córdoba. 2006. p. 346-350

MATOS, A. A importância da documentação e gestão das coleções na qualidade e certificação dos Museus. In: SEMEDO, A; COSTA, P. (Orgs.). Ensaios e práticas em museologia, Universidade do Porto. Faculdade de Letras. 2011. p.5-22.

MENSCH, P. van. Museology and the object as a data carrier. Informatologia Yoguslavica. 18 (1-2); 1986. p. 35-43.

MOGALAKWE, M. The use of documentary research methods in social research. African Sociological Review. 10 (1). 2006. p.221-230.

MOLES, A. Objeto e comunicação. In: MOLES, A. et. al. Semiologia dos objetos. Petrópolis: Ed. Vozes. 1972. p. 9-41. (Coleção Novas Perspectivas em Comunicação 4)

MONTGOMERY, Charles. The connoisseurship of artifacts. In: SCHLERETH, T. J. Material Culture Studies in America. Maryland: Altamira Pressa. 1999. p.143-152.

MUSEUMS AND GALLERY COMISSION (MGC). Guidelines for a registration scheme for a museum in the United Kingdom. In: FAHY, A. (org). Collections Management. LondresNova York: Routledge. 1995. p. 35-65.

ORTEGA, C. D. Surgimento e consolidação da documentação: subsídios para compreensão da história da Ciência da Informação no Brasil. Perspectivas em Ciência da Informação. v.14. número especial. 2009. p.59-79.

ORTEGA, C. D. LARA, M. L. G. de. A noção de documento: de Otlet aos dias de hoje. DataGramaZero. $\quad$ v. $11 . \quad$ n.2. abril. 2010. Disponível em: <http://www.dgz.org.br/abr10/Art_03.htm>. Acesso em: 19 jan. 2014.

OTLET, P. Traité de documentation: le livre sur le livre, théorie et pratique. Bruxelles: Editions Mundaneum. 1934.

PEARCE, S. Museum Studies in Material Culture. London: Leicester University Press, 1989.

Museums, Objects and Collections: a cultural study. Washington D.C.: Smithsonian Institution Press. 1992. $\overline{\text { p.139-143 }}$

Interpreting objects and collections. Londres. Nova York: Routledge. 1994.

PÉREZ, A. C. La documentación en los museos: una visión general. Museo. n.2. 1997. p. 11-29.

PESEZ, J-M. História da cultura material. In: LE GOFF; J. CHARTIER; R, REVEL, J (dir.). A História Nova. 5ª ed. São Paulo: Martins Fontes. 2005. p.237-285.

POMIAN, K. Colecção. In: ENCICLOPÉDIA Einaudi. Lisboa: Imprensa Naciona. Casa da Moeda. 1984. p. 51-86.

PROWN, J. D. Mind in matter: an introduction to material culture theory and method. Winterthur Portfolio. vol. 17. n. 1. Primaver. 1982. p. 1-19. 
The truth of material culture: history or fiction. In: LUBAR, S.; KINGERY, W. D.

History from things: essays on material culture. Londres, Washington: Smithsonian Institution Press. 1993. p. 1-19.

REDE, M. História a partir das coisas: tendências recentes nos estudos de cultura material. Anais do Museu Paulista. São Paulo. n. sé. v. 4. jan-dez. 1996. p. 281-291.

REPARTIÇÃO GERAL DOS TELÉGRAFOS - RGT. Memória histórica: A Repartição Geral dos Telégrafos. Rio de Janeiro: Tipografia Imperial. 1907.

ROBERTS, A. Inventories and documentation. In: ICOM. Running a museum - a practical handbook. France: Maison de l'UNESCO. 2004. p.31-50.

ROLLAND-VILLEMONT, B. La conservation et la restauration du patrimoine industriel, les limites de la muséographie. In: ICOFOM/ICOFOM LAM - International Symposium Museology and Memory. Paris-Grenoble, França. 1997. Documentos de Trabalho... Paris/Grenoble: ICOFOM Study Series - ISS 27. 1997. P. 143-148.

SANTIAGO, M. A. O. A história centenária do Museu dos Correios. Revista Postais. Brasília: Museu Nacional dos Correios. n.1. v.1. 2013. p. 10-25.

SANTOS, P. Paul Otlet: um pioneiro da organização das redes mundiais de tratamento e difusão da informação registrada. Ciência da Informação, v. 36. n. 2. maio/ago. 2007. p. 54-63.

SCHLERETH, T. J. Material Culture Studies in America. Maryland: Altamira Pressa. 1999.

SEKARAN, U. Research methods for business: a skill-building approach. Forth Edition. USA: John Wiley \& Sons, Inc. 2003.

SMIT, J. A documentação e suas diversas abordagens. In: SANTOS, C. P.; LOUREIRO, M. L. N. Documentação em Museus. Rio de Janeiro: Museu de Astronomia e Ciências Afins. 2008. p. 11-22 (MAST Colloquia 10)

SILVA, M. C.; MOREIRA, I. C. A introdução da telegrafia elétrica no Brasil (1852-1870). Revista da SBHC, Rio de Janeiro, v. 5, n. 1, p. 47-62, jan-jul. 2007.

SOUZA, D. M. V. Informação e construção de conhecimento no horizonte museológico. DataGramaZero. v. 10. n.6. dez. 2009.

STOCKING. Jr, G. Essays on museum and material culture. In: STOCKING, Jr.; GEORGE, W. (ed.) Objects and others: essays on museum and material culture, history and antropology. The University of Wisconsins Press, 1985. v.3. p. 3-14.

STURCHIO, J. Artifact and experiment. Isis. v. 79. n. 3. 1988. p. 368-372.

THORNES, R.; DORRELL, P.; LIE, H. Object ID: guidelines for making records that describe art, antiques, and antiquities. Los Angeles: J. Paul Getty Trust. ICOM/GETTY. 1999. 
Anexo I - Ficha Catalográfica em Papel Criada na Década de 1970

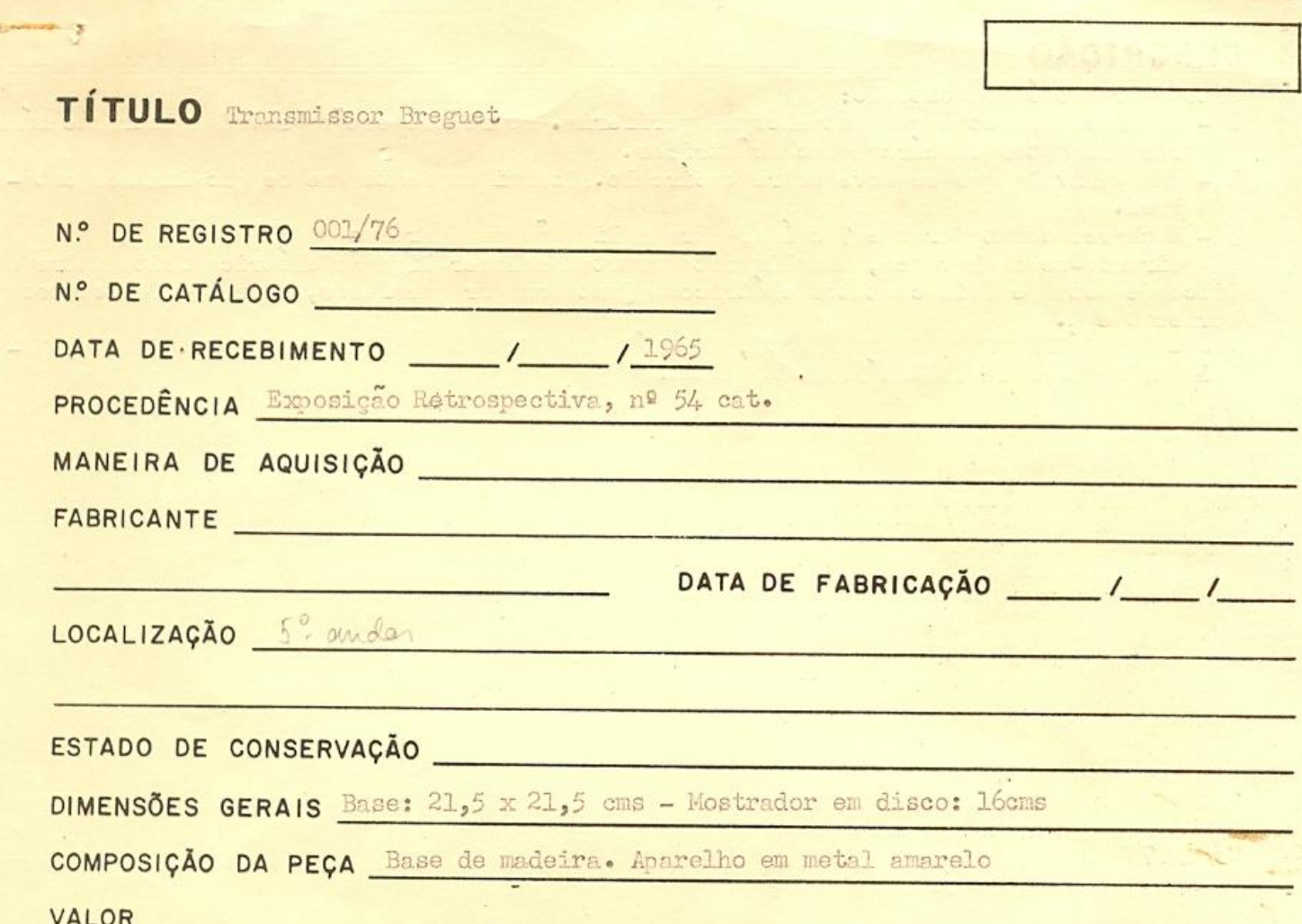

VALOR

HISTÓRICO 


\section{DESCRIÇÃO}

Este aparelhoé composto de:

1 - un disco de meṫl com entalhes na periferia. Sobre ele estão gravadas letras e nún ros dispostos em circulos concêntricos.

2 - uma manivela que se move sobre o círculo. Possui um dente que se encaixa nos entaIhes.

3 - 2 chaves comutadoras e 7 saídas pare a ligagão do aparelho

Girando-se a alavanca, una lingueta comuta qualquer ligação elétrica feitia entre o disco de metal e dois contatos elétricos ajustados por perafusos, correspondentes aos bornes $\mathrm{C}$ e R.

VEJA_SE A PÁGTNA DE PESQUISA ANEXA, EXTRAfDA DO CURSO DE TEIEGRAFIA DE Mr. TONGAS, PUBIICADO NA "REVISTA TEIEGRÁFICA • BRASIIEIRA"

CONSULTORIA Técnica: Eng •Telecomunicações Virgíliio de Braga Melio

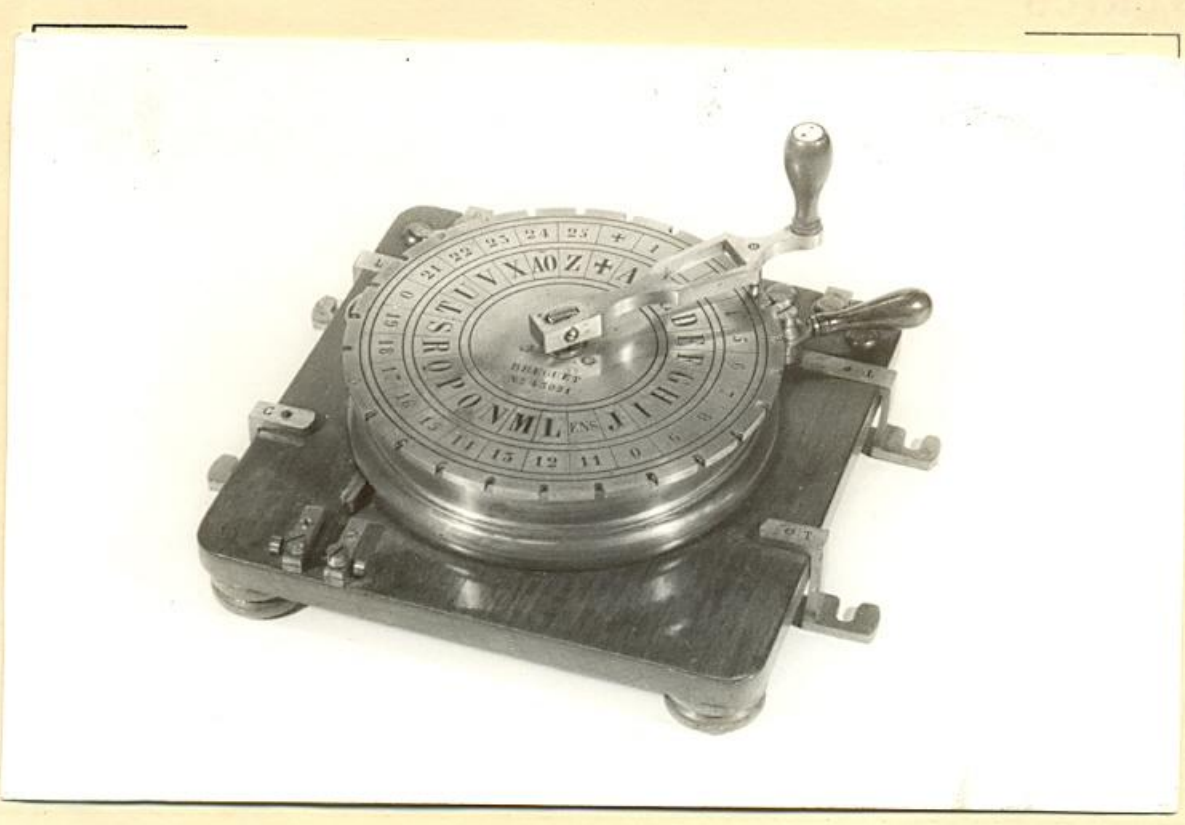


Ficha de Identificação

\begin{tabular}{|c|c|c|c|c|}
\hline \multirow{3}{*}{$\Sigma$ Corre } & IUSEU & \multicolumn{3}{|c|}{ № DE REGISTRO: } \\
\hline & \multicolumn{2}{|c|}{ MUSEU CORREIOS } & \multicolumn{2}{|c|}{ № PIB: 10042431} \\
\hline & & & \multicolumn{2}{|c|}{ № ANTERIOR: } \\
\hline 1. TíTULO: & Aparelho Morse & $\begin{array}{l}\text { 9. MARCAS / } \\
\text { INSCRIÇÕES / } \\
\text { ASSINATURA: }\end{array}$ & & \\
\hline \multirow{3}{*}{ 2. AUTORIA: } & & \multirow{3}{*}{$\begin{array}{l}\text { 10. DIMENSÃO } \\
\text { GERAL: }\end{array}$} & $\begin{array}{l}\text { Altu } \\
51 \mathrm{cI}\end{array}$ & $\begin{array}{l}\text { ra: 22cm Largura: } \\
n\end{array}$ \\
\hline & & & Con & Prof.: $38 \mathrm{~cm}$ \\
\hline & & & Pes & \\
\hline \multirow{2}{*}{$\begin{array}{l}\text { 4. ÉPOCA / } \\
\text { ANO: }\end{array}$} & & \multicolumn{3}{|c|}{ 11. ESTADO DE CONSERVAÇÃO: } \\
\hline & & \multirow{2}{*}{$\begin{array}{l}\text { ÓTIMO: ( ) } \\
\text { REGULAR: ( ) }\end{array}$} & & BOM: (x ) \\
\hline \multirow{3}{*}{ 5. CATEGORIA: } & & & & PÉSSIMO: ( ) \\
\hline & & \multicolumn{3}{|c|}{\begin{tabular}{|l|l|} 
12. LOCALIZAÇÃO: & RT01 (Ed. Apolo)
\end{tabular}} \\
\hline & & \multirow{2}{*}{\multicolumn{2}{|c|}{$\begin{array}{l}\text { 13. MODO DE } \\
\text { AQUISIÇÃO: }\end{array}$}} & Coleta \\
\hline \multirow{2}{*}{$\begin{array}{l}\text { 6. MATERIAL } \\
\text { (IS): }\end{array}$} & \multirow{2}{*}{$\begin{array}{l}\text { Madeira, vidro, baquelite, } \\
\text { metal, papel }\end{array}$} & & & \\
\hline & & 14. DATA DE & & $05 / 03 / 2013$ \\
\hline \multirow{2}{*}{ 7. TÉCNICA (S): } & & & & \\
\hline & & \multicolumn{2}{|c|}{ 15. PROCEDÊNCIA: } & SOF SUL \\
\hline \multicolumn{2}{|l|}{ 8. FOTO: } & \multicolumn{3}{|c|}{$\begin{array}{l}\text { 16. DESCRIÇÃO ICONOGRÁFICA DO } \\
\text { OBJETO: }\end{array}$} \\
\hline & & \multicolumn{3}{|c|}{$\begin{array}{l}\text { Aparelho para transmissão de mensagens } \\
\text { usando código morse. Base em madeira } \\
\text { contendo uma gaveta com puxador em metal. } \\
\text { Dentro da gaveta rolo de papel em base de } \\
\text { metal. Acima da base de madeira, um aparelho } \\
\text { em metal para recebimento de mensagens, } \\
\text { contendo manivela e maquinário. Esse } \\
\text { aparelho apresenta placa de PIB antigo fixada } \\
\text { com número 12228. Contém, também, aparelho } \\
\text { para medição em miliamperímetro da marca } \\
\text { ENGRO (Ind. Brasileira). }\end{array}$} \\
\hline
\end{tabular}



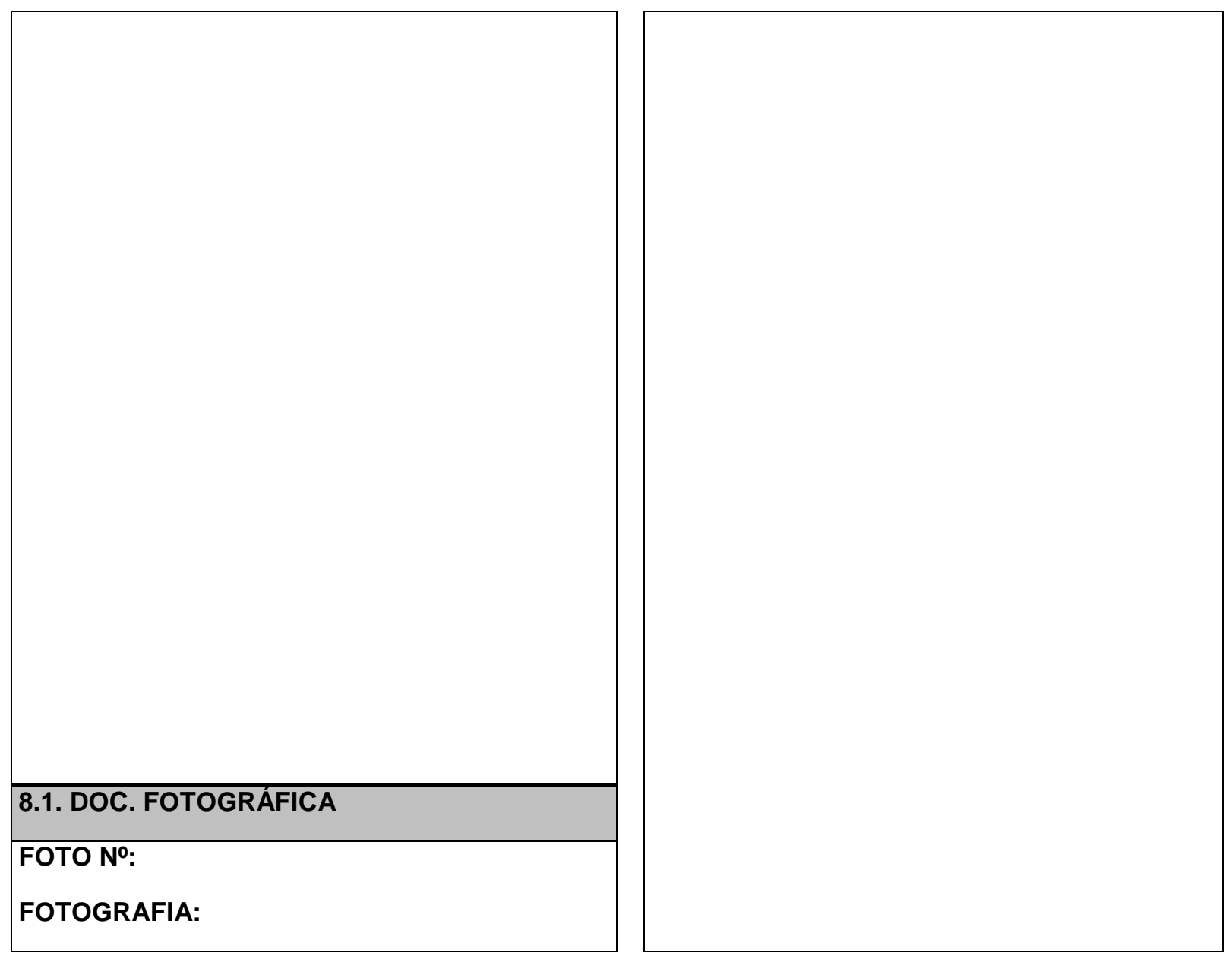

\section{HISTÓRICO DO OBJETO (ICONOLOGIA):}

\section{OBSERVAÇÕES}

Essa peça, antes de ir para o SOF Sul estava na CST/DR/BSB. O exemplar apresentava, também, etiqueta de Inventário de 2005, o que indica que, ao menos nesse ano, ele se encontrava na DR. 
19. REFERÊNCIAS BIBLIOGRÁFICAS:

21. DOCUMENTALISTAS / MUSEÓLOGOS

(AS):

22. DATA:

06/03/2013

23. DIGITAÇÃO/ DATA:

24. REVISÃO/DATA: 


\section{Apêndice I - Proposta de Campos para Ficha Catalográfica para o Museu Correios}

Os dados abaixo organizados foram selecionados de forma a propor uma ficha catalográfica específica para a coleção de telegrafia do Museu Correios. Os campos foram selecionados e compilados dos documentos elaborados pelo CIDOC, pela Collections Trust (Spectrum) e pelo Museu de Astronomia e Ciência Afins. A configuração em fichas catalográficas e organização dos campos fica a cargo da instituição.

Dados Institucionais e Administrativos

Nome:

Endereço completo:

Pessoa Jurídica ou Pessoa Física responsável:

CNPJ:

Outro número de registro da instituição:

Numero da peça:

Outros números:

№ do processo de entrada:

Data do registro:

Data de aquisição:

Método de aquisição:

Preço:

Valor:

Histórico de procedência:

Contribuições de donos anteriores:

Condições e restrições:

\section{Aspecto Físico}

Título/Nome:

Classificação (termo geral do thesaurus):

Tipo de objeto (termo específico do thesaurus):

Descrição física:

Medidas (com unidade de medidas): 
Partes e componentes:

Medidas das partes e componentes (com unidade de medidas):

Características diferenciais:

Marcas e inscrições (método, transcrição, tradução, posição, idioma e tipo de inscrição):

Material (componente, nome e origem do material):

Técnica:

\section{Histórico e Função}

Produção (data, origem, organização, entidade ou indivíduo fabricante, local):

Atributo técnico (função e funcionamento):

Período de uso:

Associação (atividades, conceito, afinidade cultural, data, data do evento, nome do evento, organização participante, entidade, comunidade ou indivíduo participante, local do evento, notas sobre o histórico do objeto):

\section{Vida Pós-Musealização}

Imagem:

Localização atual:

Localização habitual:

Dados de movimentação:

Conservação (estado, data, tratamento, data, próxima verificação, data e motivo do dano, restauração, responsável pelo procedimento, data, procedimento, materiais,

recomendações de exposição, condições ambientais, manuseio, embalagem, segurança, armazenagem):

Referências bibliográficas e arquivísticos:

Exposições e produções bibliográficas:

Direitos Autorais e requisitos legais (incluindo período e no do processo):

Seguro (nota, numero de apólice, no de referencia, data de renovação, seguradora):

Catalogador

Histórico de alterações dos dados

Documentos anexados: cópias de laudos de conservação, de exames realizados no objeto, lista de referências, lista de imagens, certificados (como por ex. calibração, autenticidade, etc), documentos de doação, empréstimos, transferência, baixa patrimonial e alienação,

Baixa/Alienação (data, método, nota, receptor proposto, condiçoes/restrições, justificativa, receptor, preço da alienação) 